\title{
Efficacy of macronutrients on targeting obesity and beyond
}

Citation for published version (APA):

Soenen, S. (2010). Efficacy of macronutrients on targeting obesity and beyond. [Doctoral Thesis, Maastricht University]. Universitaire Pers Maastricht. https://doi.org/10.26481/dis.20100122ss

Document status and date:

Published: 01/01/2010

DOI:

10.26481/dis.20100122ss

Document Version:

Publisher's PDF, also known as Version of record

\section{Please check the document version of this publication:}

- A submitted manuscript is the version of the article upon submission and before peer-review. There can be important differences between the submitted version and the official published version of record.

People interested in the research are advised to contact the author for the final version of the publication, or visit the DOI to the publisher's website.

- The final author version and the galley proof are versions of the publication after peer review.

- The final published version features the final layout of the paper including the volume, issue and page numbers.

Link to publication

\footnotetext{
General rights rights.

- You may freely distribute the URL identifying the publication in the public portal. please follow below link for the End User Agreement:

www.umlib.nl/taverne-license

Take down policy

If you believe that this document breaches copyright please contact us at:

repository@maastrichtuniversity.nl

providing details and we will investigate your claim.
}

Copyright and moral rights for the publications made accessible in the public portal are retained by the authors and/or other copyright owners and it is a condition of accessing publications that users recognise and abide by the legal requirements associated with these

- Users may download and print one copy of any publication from the public portal for the purpose of private study or research.

- You may not further distribute the material or use it for any profit-making activity or commercial gain

If the publication is distributed under the terms of Article $25 \mathrm{fa}$ of the Dutch Copyright Act, indicated by the "Taverne" license above, 


\section{Efficacy of macronutrients on targeting obesity and beyond}


The research described in this thesis was supported by Top Institute Food and Nutrition (TIFN). The study of which results are presented in chapter 2 was sponsored by Suikerstichting Nederland, and the study in chapter 10 by Unilever Corporate Research. For data collection for chapter 8 and 9 collaboration with Previtas is gratefully acknowledged.

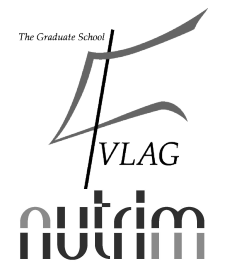

The studies presented in this thesis were performed at the School for Nutrition, Toxicology and Metabolism (NUTRIM), which participates in the Graduate School VLAG (Food Technology, Agrobiotechnology, Nutrition and Health Sciences) accredited by the Royal Netherlands Academy of Arts and Sciences (KNAW).

Financial support by Previtas and the Netherlands Association for the Study of Obesity (NASO) for the publication of this thesis is gratefully acknowledged.

Cover design: Judith Dierkes and Stijn Soenen Layout: Stijn Soenen

Printed by: Datawyse, Universitaire Pers Maastricht

(C) Stijn Soenen, Maastricht 2009

ISBN: 9789052789071 


\section{Efficacy of macronutrients on targeting obesity and beyond}

\section{PROEFSCHRIFT}

ter verkrijging van de graad van doctor aan de Universiteit Maastricht, op gezag van de Rector Magnificus, Prof. mr. G.P.M.F. Mols

volgens het besluit van het College van Decanen, in het openbaar te verdedigen op vrijdag 22 januari 2010 om 10.00 uur

door

Stijn Soenen

geboren te Gent op 27 februari 1978

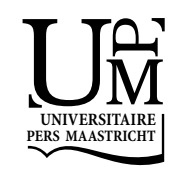




\section{Promotor}

Prof. dr. M.S. Westerterp-Plantenga

\section{Beoordelingscommissie}

Prof. dr. K.R. Westerterp (voorzitter)

Prof. dr. A. Astrup (University of Copenhagen, Denmark)

Prof. dr. P. Clifton (CSIRO Human Nutrition, Adelaide, Australia)

Prof. dr. ir. A.M.W.J. Schols

Prof. dr. F-.J. van Schooten 
Aan mijn ouders en mijn lieve Judith 



\section{TABLE OF CONTENTS}

\begin{tabular}{|c|c|c|}
\hline Chapter 1 & General introduction & 9 \\
\hline Chapter 2 & $\begin{array}{l}\text { No differences in satiety or energy intake after High-Fructose Corn } \\
\text { Syrup, sucrose, or milk preloads }\end{array}$ & 23 \\
\hline Chapter 3 & Proteins and satiety: implications for weight management & 45 \\
\hline Chapter 4 & $\begin{array}{l}\text { Sustained intake of required protein optimal for weight loss, } \\
\text { supra-sustained protein intake optimal for weight maintenance }\end{array}$ & 57 \\
\hline Chapter 5 & $\begin{array}{l}\text { Protein intake induced changes in body composition in energy } \\
\text { balance }\end{array}$ & 77 \\
\hline Chapter 6 & $\begin{array}{l}\text { Protein intake induced increase in exercise stimulated fat } \\
\text { oxidation in energy balance }\end{array}$ & 87 \\
\hline Chapter 7 & $\begin{array}{l}\text { Efficacy of alpha-lactalbumin for weight loss compared to } \\
\text { sustained and supra-sustained milk protein }\end{array}$ & 99 \\
\hline Chapter 8 & $\begin{array}{l}\text { Elevated protein recommended and lowered carbohydrate } \\
\text { additionally suggested for optimal weight loss }\end{array}$ & 117 \\
\hline Chapter 9 & $\begin{array}{l}\text { Effect of carbohydrate content of protein leverage diets on } \\
\text { efficacy of weight maintenance upon weight loss }\end{array}$ & 133 \\
\hline Chapter 10 & $\begin{array}{l}\text { Relationship between perilipin gene polymorphisms and body } \\
\text { weight and body composition during weight loss and weight } \\
\text { maintenance }\end{array}$ & 149 \\
\hline \multirow[t]{6}{*}{ Chapter 11} & General discussion & 165 \\
\hline & Summary & 177 \\
\hline & Samenvatting & 183 \\
\hline & Dankwoord & 189 \\
\hline & List of publications & 193 \\
\hline & About the author & 199 \\
\hline
\end{tabular}





\section{GENERAL INTRODUCTION}




\section{OBESITY: BODY WEIGHT GAIN vS. BODY WEIGHT} MAINTENANCE

Obesity, one of the major health problems of today, is a condition in which fat is accumulated to excess, and body weight and fat percentage are increased. As obesity is associated with increased risk of several diseases such as hypertension, diabetes mellitus type 2, coronary heart disease and cancer (1-3), it is relevant to target the excess of fat accumulation and prevent body-weight gain during lifetime. Body weight gains as a result of a positive energy balance, which occurs when energy intake exceeds energy expenditure. The desired goal for the treatment and the reduction of development of body-weight gain or obesity is to decrease fat mass whilst preserving or increasing fat free mass. The resulted higher ratio of fat free mass to fat mass plays an important role in the maintenance of energy balance and body weight, as fat free mass is the main determinant of basal energy expenditure (4), and the preservation of metabolic and overall health $(5,6)$. Maintenance of body weight is achieved when energy intake is adjusted to energy expenditure. Maintenance of body weight seems simple, however the required conditions are difficult to achieve for the individual. Usually, the pitfall appears to be body-weight regain after initial body-weight loss (3). Conditions for body-weight maintenance after body-weight loss are sustained satiety despite negative energy balance, and sustained basal energy expenditure despite bodyweight loss due to sparing of fat free mass. The failure to maintain body weight after an initial successful body-weight loss as a result of a specific diet may be ascribed in part to genetic factors. Some individuals are more prone to gain body weight when exposed to a given diet, because of susceptibility of a specific genetic background. Therefore, the development of obesity is determined by both genetic and environmental factors, such as diet $(1,2)$.

This chapter starts with the concepts of energy intake and energy expenditure, and the impact of the macronutrients: protein, carbohydrate and fat, there upon, followed by an overview of dietary-protein content related to energy intake, energy expenditure and body composition, and thereby its effectiveness to target daily positive energy balance or the development of obesity.

\section{ENERGY INTAKE}

Intake of energy or meal initiation is driven by hunger, a response to a drive to fulfill a physiological need for energy or macronutrients. Appetite reflects one's desire to eat. Satiation refers to inhibition of hunger and appetite within a meal, and is related to meal termination. Satiety refers to inhibition of hunger and appetite after a meal, and is related to inter-meal interval and meal frequency. Hunger, appetite, satiation and satiety are related to gastric sensations, gut peptides, neuropeptides, hormones, and substrates such as amino acids, glucose and free fatty acids of the macronutrients protein, carbohydrate and fat. To determine the impact of a macronutrient on shortterm food-intake regulation, a preload-study design is often used. Within this study design a preload drink or food of a specific macronutrient composition is administered to a volunteer, and hunger and satiety are rated to determine the time interval of the test meal to measure ad libitum food intake. The impact of a specific food component, such as the in the US widely used sweetener high-fructose-corn-syrup (HFCS), which is 
hypothesized to play a role in the development of obesity, is compared with an other energy delivering sweetener sucrose, a sweetener without energy and milk in chapter 2. Besides comparing food components that possibly increase food intake and result into a positive energy balance, food components that have the potential to decrease food intake and result into a negative energy balance are well studied. Furthermore, to target obesity, the short-term effectiveness of a promising diet with specific macronutrient composition to increase satiation and satiety and/or reduce hunger, appetite and food intake, should also be effective in the longer term and result into increased weight loss during energy restriction to target obesity and/or weight maintenance to prevent the onset of or worsen the state of obesity. Here, proteins are of particular interest, chapter 3 reviews the implications of satiety of proteins on weight management, and chapters 4 to 9 further reveals the impact of the satiating capacity of proteins on energy balance over different time intervals.

\section{ENERGY EXPENDITURE}

Daily energy expenditure or average daily metabolic rate (ADMR) consists of sleeping metabolic rate (SMR) and the energy cost of arousal forming together the energy expenditure for maintenance: basal metabolic rate (BMR) or resting energy expenditure (REE), the energy cost of physical activity or activity induced energy expenditure (AEE), and the thermic effect of food or diet induced energy expenditure (DEE). The main determinant of DEE is the amount of food ingested quantified as the energy content of the food. Diet induced energy expenditure is related to the stimulation of energy-requiring processes during the postprandial period. The intestinal absorption of nutrients, the initial steps of their metabolism and the storage of the absorbed but not immediately oxidized nutrients (7). The most common way to express DEE is derived from this phenomenon: the difference between energy expenditure after food consumption and REE, divided by the rate of nutrient energy administration. In healthy subjects with a mixed diet, DEE represents about $10 \%$ of the total amount of energy ingested over 24 hours. When a subject is in energy balance, where energy intake equals energy expenditure, DEE is $10 \%$ of daily energy expenditure.

\section{EFFECTS OF THE MACRONUTRIENTS: PROTEIN, CARBOHYDRATE AND FAT ON ENERGY INTAKE, ENERGY EXPENDITURE AND SUBSTRATE OXIDATION}

A hierarchy prevails for the satiating efficacies of the macronutrients protein, carbohydrate and fat, with protein being the most satiating and fat the least. This sequence also represents the priority with respect to metabolizing these macronutrients (8). The metabolic fate of the macronutrients after ingestion is related to their storage capacity. The storage capacity for protein and carbohydrate is limited and converting these nutrients to a more readily stored form is energetically expensive. Oppositely, the storage capacity for fat is potentially very large. So, energy expenditure has a specific order in which it burns up the macronutrients since it can store an excess intake of some fuels less readily than others: protein $<$ carbohydrate $<$ fat. Therefore, postprandial energy expenditure of a mixed meal is mainly oxidation of carbohydrate and protein followed by fat oxidation in the fasted state. Reported thermic effect of 
food or diet induced energy expenditure values for the separate nutrients are 20 to $30 \%$ for protein, 5 to $10 \%$ for carbohydrate, and 0 to $3 \%$ for fat (7). Protein induces the largest rise in energy expenditure due to the energetic cost of protein synthesis, gluconeogenesis and ureogenesis. Energy expenditure and substrate oxidation measured over 24 hours in a respiration chamber shows that protein intake is associated with almost threefold higher diet induced energy expenditure in comparison with fat intake, without a difference between lean and obese participants (7). Thus over the long term, high-protein diet induced energy expenditure may contribute to the prevention of obesity or, vice versa, regular or frequent fat intake may contribute to the development and maintenance of obesity. Besides energy expenditure, elevated protein diets act on energy intake and body composition. Doubling the relative protein content of the diet from the normal level of $10-15 \%$ of energy to $20-305$ of energy reduces food intake under ad libitum conditions, resulting in immediate body-weight loss. In the long term, body weight reaches a new value at a significantly lower level. Increasing protein intake also increases the chance of maintenance of body weight after body-weight loss induced by an energy-restricted diet. Here, one of the mechanisms is a sparing effect of fat free mass, reducing the body-weight loss induced reduction of energy expenditure. Thus, an increase in the relative protein content of the diet is promising to reduce the risk of a positive energy balance and the development of obesity. The efficacy of elevated protein and lowered carbohydrate intake during a negative energy balance (chapter 8) and positive energy balance thereafter (chapter 9), the efficacy of elevated milk protein (chapter 4) and elevated alpha-lactalbumin protein (chapter 7) during a negative energy balance, and the efficacy of elevated milk protein during energy balance (chapter 5) on changes in body weight and body composition will be discussed in the following chapters.

\section{ABSOLUTE vs. RELATIVE PROTEIN INTAKE}

The World Health Organization (WHO) recommends that dietary protein should account for around $10-15 \%$ of energy when individuals are in energy balance and weight stable. Protein intake may be expressed 'absolutely' in grams, or 'relatively' as percentage of energy intake (Table 1.1). When recommending high-protein diets, the difference between these two measures should be taken into account. Relatively highprotein diets for body-weight loss and body-weight maintenance thereafter consist of at least $18-30 \%$ of energy from protein. This relative increase (in percent of energy) in protein intake during energy restriction implies during this energy restriction a sustained normal protein intake (in grams) as it was before the energy restriction. Such diets are relatively high in protein, expressed as percentage energy from protein, but in absolute terms, expressed as grams of protein, they only contain a sufficient absolute amount of protein but less energy in total. Therefore, the absolute amount of protein is the same in a relatively normal protein diet (10-15\% of energy from protein) in energy balance (energy intake matches energy requirement set by energy expenditure), as in a relatively high-protein diet (18-30\% of energy from protein) in negative energy balance (energy intake is lower than energy requirement set by energy expenditure), when subjects consume part of their energy requirements in order to lose body weight. For instance, $108 \mathrm{~g}$ protein/day with a weight-maintenance diet of $12 \mathrm{MJ} /$ day provides $15 \%$ of energy from protein; but the same protein intake as part of a weight loss diet of 
$6 \mathrm{MJ} / \mathrm{d}$ provides $30 \%$ of energy from protein, and as part of a weight-maintenance diet after weight loss of $9 \mathrm{MJ} / \mathrm{d}$ provides $22.5 \%$ of energy from protein. To ensure that subjects are not in a negative nitrogen and protein balance during weight loss, and, therefore, lose their metabolically active fat free mass, the absolute amount of protein is of greater importance than the percentage of protein. The impact of this concept of sustaining the absolute amount of protein during strict and mild energy restriction in overweight (chapters 4 and 7) and obese (chapters 8 and 9) subjects on sparing of fat free mass and reduction of fat mass and fat percentage is compared to absolute amounts exceeding the WHO-criteria during energy balance.

Table 1.1. Absolute or relative 'normal' or 'high' protein diets

\begin{tabular}{|c|c|c|c|}
\hline & Relative energy $\%$ of protein & $\begin{array}{l}\text { Energy intake of protein } \\
\mathrm{MJ} / \mathrm{d}\end{array}$ & $\begin{array}{l}\text { Absolute gram of protein } \\
\mathrm{g} / \mathrm{d}\end{array}$ \\
\hline \multicolumn{4}{|c|}{ Energy balance e.g. $12 \mathrm{MJ} / \mathrm{d}$} \\
\hline Normal & WHO-criteria: 10 - $15 \%$ & $1.2-1.8$ & $67-100$ \\
\hline High & $18-30 \%$ & $2.2-3.6$ & $120-200$ \\
\hline \multicolumn{4}{|c|}{ Negative energy-balance e.g. $2 \mathrm{MJ} / \mathrm{d}$} \\
\hline 'Normal' & $10-15 \%$ & $0.2-0.3$ & $11-17$ \\
\hline 'High' & Very Low Energy Diet: 47 \% & 0.9 & 52 \\
\hline \multicolumn{4}{|c|}{ Positive energy-balance after body weight-loss e.g. $8 \mathrm{MJ} / \mathrm{d}$} \\
\hline 'Normal' & $10-15 \%$ & $0.8-1.2$ & $44-67$ \\
\hline 'High' & $18-30 \%$ & $1.4-2.2$ & $80-120$ \\
\hline
\end{tabular}

Example of calculated gram of protein ingested when relatively normal or high-protein diets are consumed in energy balance of for instance $12 \mathrm{MJ} / \mathrm{d}$, or in negative energy balances of respectively $2 \mathrm{MJ} / \mathrm{d}$, as during a Very Low Energy Diet, or $8 \mathrm{MJ} / \mathrm{d}$, as during a weight-maintenance diet thereafter. The example shows that during a 'high' protein energy restricted diet, absolute protein intake in the given ranges is still in the originally 'normal' range.

\section{PROTEIN AND ENERGY INTAKE}

At present, the state of the art concerning protein intake and energy intake is as follows. In daily life, mixed proteins are consumed, from meat, fish, dairy products, or plants. In experiments, a dose-dependent satiating effect of mixed protein is shown, with quite a range of concentrations of protein offered acutely, in a single meal or drink, to subjects who are in energy balance and weight stable $(8,9)$. In addition, persistent protein-induced satiety is shown when a mixed high-protein diet is given for 24 hours up to several days $(8,10-13)$. Comparing effects of different proteins in different concentrations on energy intake during the subsequent meal, incomplete protein, i.e. those that lack some essential amino acids had a more satiating effect than complete proteins, i.e. those that have the essential amino acids on board (8).

When high-protein menus are offered at each meal, lasting for one to several days, one gets into the condition of an elevated-protein intake, when metabolic reactions have been established $(8,10,11)$. High protein-diet-induced satiety is primarily related to elevated energy expenditure $(8,10,11)$ implying increased oxygen consumption and an increase in body temperature both leading to feeling deprived of oxygen and thus promoting satiety (8). Energy expenditure is different due to different protein sources, and mediated by the high ATP costs of postprandial-protein synthesis and gluconeogenesis while digestion rate also plays a role. Moreover, during high-protein diets substrate oxidation changes, in that less protein is oxidized than consumed 
resulting in a positive protein balance, and more fat is oxidized than consumed, resulting in a negative fat balance; moreover, energy expenditure is continuously elevated $(8,10,11)$.

The effect of protein intake on energy expenditure is reflected mainly in two of the four components that daily energy expenditure consists of, i.e. SMR and the energy cost of arousal forming together REE, AEE, and DEE. Protein intake affects primarily DEE and ultimately SMR. Effects of protein intake on AEE are usually described in the opposite way, physical activity affecting protein metabolism, more specifically protein turnover.

Substitution of carbohydrate with $18 \%$ of energy as protein produces $3 \%$ higher 24-hour energy expenditure despite a $10-15 \%$ lower energy intake at the high-protein diet because of a higher satiating effect. The observed increase in energy expenditure is visible in SMR as well as in DEE (11). Also in energy balance, a high-protein diet of 30,40 , and $30 \%$ of energy of protein, carbohydrate and fat, vs. 10,60 , and $30 \%$ of energy increases 24-hour thermogenesis, SMR, protein balance, and fat oxidation (14). The biological rationale behind the higher thermogenic effect of protein than of carbohydrate is explained by the fact that the body has no storage capacity to cope with high intakes of protein and therefore has to process it metabolically, which readily increases thermogenesis. The ATP required for the initial steps of metabolism and oxidation including urea synthesis might explain the short-term protein induced increase in DEE. The long-term protein induced increase of SMR might be explained by stimulation of protein synthesis and protein turnover. Indirect evidence for the latter comes from the study of Mikkelsen et al. (14), where animal protein in pork meat produces $2 \%$ higher 24-hour energy expenditure than the vegetable protein in soy. The amount of protein synthesis after protein intake depends on how well the composition of essential amino acids in the dietary protein matches the optimum requirements for protein synthesis in the body. A well-balanced amino acid mixture produces a higher thermogenic response than does an amino acid mixture with a lower biological value, i.e., a different amino acid composition than is used for protein synthesis. Remaining questions are the longer-term effects of protein intake on overall daily energy intake reflected in body-weight development over time as a result of sustained vs. suprasustained baseline protein intake during energy restriction, thereby promoting bodyweight loss, and weight maintenance thereafter, discussed in chapters 4 and 7, and combined with low- and normal-carbohydrate intake in chapters 8 and 9 .

\section{PROTEIN-AND ENERGY-METABOLISM}

Taking into account the indirect and unpredictable pathways of protein metabolism, interaction between energy expenditure and protein metabolism is highly relevant to assess. Protein intake is the most important dietary determinant of whole-body protein turnover (15-18). Furthermore, protein turnover and metabolism is strongly influenced by protein quality, as protein synthesis requires adequate availability of essential amino acids. In other words, the intake of sufficient levels of these amino acids is crucial for preventing negative protein balance. A specific appetite for essential amino acids has therefore been suggested, which is supported by the observation that rats, when fed a diet deficient in one or more essential amino acids, are able to recognize the presence of these amino acids in a range of diets with or without these amino acids $(19,20)$. 
Such a sensing mechanism stresses the physiological importance of maintaining an adequate rate of protein synthesis.

When ingested in surplus of postprandial protein synthesis, amino acids can readily be used as substrate for oxidation. In elderly women, increasing the amount of dietary protein from 10 to $20 \%$ of energy results in a 63 to $95 \%$ increase in protein oxidation, depending on the protein source (21). The largest (95\%) increase in protein oxidation is observed when the predominant protein source is of animal origin, whereas this increase is only $63 \%$ when soy protein is the predominant protein source in the diet (21). Accordingly, as mentioned in the previous section, Mikkelsen et al. observed a higher diet induced thermogenesis with pork meat than with soy protein (14). Differences in digestion rate of the various protein sources may contribute to differences in postprandial protein oxidation. Thus, ingestion of rapidly digested protein results in a stronger increase in postprandial protein synthesis and amino acid oxidation than slowly digested protein (22-24).

The metabolic efficacy of protein oxidation largely depends on the amino acid composition of the protein, since large differences exist with respect to the efficacy by which amino acids are oxidized. This is due to the large variety of carbon chains and co-factors that are resulting from amino acid catabolism (25). For instance, the number of amino groups that undergo conversion to urea in the urea cycle (at a cost of 4 ATP) ranges from 1 for an amino acid such as proline or alanine to 3 for histidine $(25,26)$. Thus, taking into account the stoichiometry of amino acid catabolism and urea synthesis, the calculated energy expenditure to produce ATP is ranging from 153 $\mathrm{kJ} / \mathrm{ATP}$ for cysteine, to $99 \mathrm{~kJ} / \mathrm{ATP}$ for glutamate (for glucose, this value is $91 \mathrm{~kJ} / \mathrm{ATP}$ ) (26). Thus, even though the ATP for urea production can be derived from subsequent oxidation of the remaining carbon group itself (27), the metabolic efficacy of amino acid oxidation is relatively low (for glucose and fatty acids, the calculated energy expenditure to produce ATP is 91 and $96 \mathrm{~kJ} / \mathrm{ATP}$, respectively). This relative metabolic inefficiency may contribute to the higher DEE of a high-protein meal.

Besides protein intake, whole body protein synthesis is affected by exercise as well, especially in the period after exercise (28). The higher protein turnover is suggested to increase protein requirement for maintenance of nitrogen balance (29). In practice, exercise induces an increase in food intake and thus protein intake remains sufficient when it comprises a minimum of $10 \%$ of energy intake. The exercise-induced increase in protein turnover will contribute to the increase in REE of as much as $15 \%$ compared to sedentary subjects, observed in endurance athletes after adjustment for differences in body composition $(30,31)$. Remaining questions of protein- and energy-metabolism are the effects of protein intake on overall protein metabolism, i.e. protein turnover and energy cost of protein metabolism translated into build-up of fat free mass and increased oxidation of fat, during energy balance over a longer period in time, addressed in chapters 5 and 6.

\section{PROTEIN INTAKE AND BODY COMPOSITION}

Varying the protein content of a formula diet from 0 to $50 \mathrm{~g} /$ day resulted in a protein loss of between 1202 to 91 grams, respectively, as measured over 28 days (32). The fat loss as a percentage of total body-weight loss varied from $43 \%$ with $0 \mathrm{~g} / \mathrm{d}$ protein, up to $79 \%$ with $50 \mathrm{~g} / \mathrm{d}$ protein. These results indicate that a higher protein intake changes 
body composition in a way that it spares fat free mass. Similarly, a weight-maintenance diet following body-weight loss, sustained at an absolute amount of protein at $108 \mathrm{~g}$, will preserve fat free mass but lead to a reduction of fat mass. These changes in body composition are related to metabolic inefficiency. To build $1 \mathrm{~kg}$ of body weight with $67 \%$ fat mass and 33\% fat free mass, an additional 26-30 MJ needs to be ingested, whereas to build $1 \mathrm{~kg}$ of only fat free mass, an additional 50-70 MJ is needed $(33,34)$. Therefore, a high-protein diet may promote weight maintenance by its metabolic inefficiency because of the cost involved in sparing fat free mass. Therefore, recommendations of 'high protein, negative energy balance diets' are based on keeping the amount of protein ingested at the same level, in general representing $10-15 \%$ of energy at energy balance, despite lower energy intakes. Thus, to ensure that subjects are not in a negative nitrogen and protein balance during weight loss, and therefore, lose their metabolically active fat free mass, the absolute amount of protein is of greater importance than the percentage of protein.

Sustained protein diets for body-weight loss are assessed over different periods of time. A relatively high-protein diet, containing 25,58 and $30 \%$ of energy of protein, carbohydrate and fat, implying $75 \mathrm{~g}$ of protein per day, compared to a control diet, containing 12, 45 and 30\% of energy of protein, carbohydrate and fat, is examined with ad libitum energy intake over 6 months in subjects with a body mass index over $30 \mathrm{~kg} / \mathrm{m}^{2}$ (35). Weight loss; 8.9 vs. $5.1 \mathrm{~kg}$, and fat loss; $7.6 \mathrm{vs} .4 .3 \mathrm{~kg}$, are higher in the sustained-protein group, due to a lower energy intake, $5.0 \mathrm{MJ} / \mathrm{d} \mathrm{vs} .6 .2 \mathrm{MJ} / \mathrm{d}$. In a follow-up study, it is observed that after 12 months the weight loss is not significantly greater among the subjects in the high-protein group, but a greater reduction of intraabdominal adipose tissue appears (36). Also, in an iso-energetic high-protein diet of 30, 50 and $20 \%$ of energy of protein, carbohydrate and fat, satiety is considerably increased, but body weight remains stable during the week the subjects consume this diet (37). When the subjects subsequently receive the same high-protein diet ad libitum, for 6 weeks, they consume less of it, keeping their satiety levels at their original, 'usual' level. During the iso-energetic high-protein diet subjects do not lose body weight, whereas during the ad libitum high-protein diet they lose $4.9 \pm 0.5 \mathrm{~kg}$, with a decrease in fat mass of $3.7 \pm 0.4 \mathrm{~kg}$. Also a favorable effect of a high protein, low glycemic index, low fat diet compared to a high carbohydrate, low fat diet on body weight is found during 6 days of ad libitum feeding (38). The high-protein diet results in a spontaneous decrease in energy intake of $25 \%, 8.8 \mathrm{MJ} / \mathrm{d} \mathrm{vs} .11 .7 \mathrm{MJ} / \mathrm{d}$, and subsequent body-weight loss of $2.3 \mathrm{~kg}$ compared to no weight loss on the high carbohydrate diet. However, in comparison to an iso-energetic high-carbohydrate diet there is no significant difference in body-weight loss over the 6 days, probably due to lack of difference in energy intake. Furthermore, in a cross-over design a high-protein ketogenic diet with 30 and $4 \%$ of energy of protein and carbohydrate vs. a medium carbohydrate diet with 30 and $35 \%$ of energy of protein and carbohydrate has a lower hunger and ad libitum food intake, and greater body-weight loss (6.34 vs. $4.35 \mathrm{~kg})$ in seventeen obese men over a week (39). The low-carbohydrate diet induces ketosis with higher beta-hydroxybutyrate concentrations (39).

These studies together suggest that body-weight loss on a sustained, often indicated as a relatively high-protein diet, appears to be greater under conditions of ad libitum energy intake than under conditions of iso-energetic diets. The explanation for this is 
that satiety is a key factor in applying high-protein diets. Under ad libitum conditions subjects eat less from the high-protein diet than under iso-energetically fed conditions (37). Such diets contain a sufficient absolute amount of protein but lead to decreased energy intake, suggesting that in addition to metabolic effects of protein on bodyweight loss, energy intake plays an important role. This is underscored by the phenomenon that under iso-energetic conditions no statistically significant difference between body-weight losses on a high-protein or high-carbohydrate diet is shown. Moreover, most of the studies on protein intake in relation to body-weight management show an improved body composition (i.e. an increased fat free mass to fat mass ratio) and metabolic profile with a relatively high-protein diet. The relatively high protein negative energy balance diets all consist of $25-30 \%$ of energy from protein and imply a sustained normal protein intake in grams, while energy intake is decreased.

Studies suggest that high-protein diets can promote weight maintenance. For example, overweight to moderately obese men and women who lose weight $(7.5 \pm 2.0 \%$ body-weight loss over 4 weeks) and consume $18 \%$ of energy as protein thereafter, regain less weight $(1 \mathrm{~kg}$ ) after 3 months, compared to those consuming 15\% of energy as protein (weight regain $2 \mathrm{~kg}$ ) (40). This is not a consequence of possible differences in dietary restraint or in physical activity between the high-protein and the control group, indicating a metabolic effect of protein (13). The composition of the body mass regained is more favorable in the higher-protein group (i.e. no regain of fat mass, but only of fat free mass, resulting in a lower percentage body fat) (13). Energy efficiency (kg body-mass regain/energy intake) is significantly lower in the higher-protein group. With a similar design, a weight 'regain' of $0.8 \mathrm{~kg}$ (high-protein group) vs. $3.0 \mathrm{~kg}$ (control group) $(\mathrm{p}<0.05)$ after 6 months on a weight-maintenance diet (12). During follow-up one year after the weight-loss program, these figures are $1.0 \mathrm{~kg}$ vs. $3.9 \mathrm{~kg}$ $(p<0.05)$. Thus evidence shows that a relatively high-protein intake sustains weight maintenance by favoring regain of fat free mass at the cost of fat mass at a similar physical activity level, reducing the energy efficiency with respect to the body-mass regained, and increasing satiety. Similar observations are reported in Wistar male rats from long-term relatively high-protein diets that markedly reduce adipose tissue without major side effects (41).

Summarizing the role of dietary protein in body-weight loss and body-weight maintenance thereafter, there is a need to distinguish absolute protein intake from proportionate protein intake. Absolute protein intake seems to be more important that the proportion of protein in the diet. When energy intake is reduced protein intake should be sustained, so that expressed in grams/day the protein content is normal. Therefore, 'high protein negative energy balance diets' should mean keeping the grams of protein ingested at the same level, i.e. representing $10-15 \%$ of energy at energy balance, despite lower energy intakes (Table 1.1). Protein influences body-weight regulation via its effects on: satiety, thermogenesis, energy efficiency and body composition. These aspects are partly related to each other. Under conditions of slight body-weight regain, while aiming for weight maintenance, a sustained-protein diet shows reduced energy efficiency related to the body composition of the body-weight regained, i.e. in favor of fat free mass. Here, the main issue is that building fat free mass requires, on average, an additional energy ingestion of $52 \mathrm{MJ} / \mathrm{kg}$ body mass built, whereas building a normal proportion of fat mass and fat free mass takes $26-30 \mathrm{MJ} / \mathrm{kg}$ 
body mass built. During body-weight loss, as well as during weight maintenance thereafter, a high-protein diet preserves or increases fat free mass and reduces fat mass, and improves the metabolic profile.

\section{GENETICS}

Obesity may be explained by an interaction between genetic and environmental factors such as diet. Also the failure to maintain body-weight loss after an initial successful reduction of body weight as a result of a specific diet may be ascribed in part to genetic factors. Some individuals are more prone to gain body weight when exposed to a given diet, because of susceptibility of a specific genetic background. Although research into the influence of genetics upon obesity has been underway for many years, understanding on how the interaction between the diet and genetic variation impacts body weight and weight management still needs attention. Studies need to be performed to determine the mechanism behind the differential response in loss of body weight. Mechanistic understanding is anticipated to be a key requirement for the rational design of personalized weight-loss interventions. An association between perilipin (PLIN) gene variants and weight management has been suggested. The perilipins are part of an ancient family of proteins that interact with the surfaces of intracellular neutral lipid droplets. The predominant form expressed in adipocytes, is involved in regulating fat storage, primarily by modulating hormone sensitive lipase (HSL) activity. HSL mediates the hydrolysis of triacylglycerol, a major form of stored energy in the body. Therefore, perilipin may be a possible genetic influencer of obesity risk in humans. The question remains to what extent perilipin polymorphisms influence body-weight management. Therefore chapter 9 describes the role of the perilipin genotype on the differential response to a weight-loss weight-maintenance intervention, supported by a differential effect on body composition.

\section{OUTLINE OF THE THESIS}

The role of macronutrients in body-weight loss and body-weight maintenance encompasses the influence of dietary protein on the crucial targets for body-weight regulation, namely effects on satiety, thermogenesis, energy efficiency and body composition. These aspects are partly related to each other. Satiety and energy intake after preloads contrasting in energy-delivering macronutrients is described in chapter 2; 'No differences in satiety or energy intake after high-fructose corn syrup, sucrose, or milk preloads'. Before switching to protein as main macronutrient a review is presented in chapter 3; 'Proteins and satiety: implications for weight management', to describe the state of the art of satiety effects of the macronutrient protein and its subsequent implications for weight management. The effect of protein content of the diet on preserving or increasing fat free mass and reducing fat mass during bodyweight loss, and its relation to preservation of resting energy expenditure, as well as during weight maintenance thereafter is presented in chapter 4; 'Sustained intake of required protein optimal for weight loss, supra-sustained protein intake optimal for weight maintenance'. Chapter 5; 'Protein intake induced changes in body composition in energy balance', describes the way dietary protein triggers this fat free mass sparing effect during energy balance. Furthermore, the effects of dietary-protein intake in 
body-weight stable subjects on stimulated fat oxidation are discussed in chapter 6; 'Protein intake induced increase in exercise stimulated fat oxidation in energy balance'. Chapter 7; 'Efficacy of alpha-lactalbumin for weight loss compared to sustained and supra-sustained milk protein', compares the effects of 'high' quality protein, i.e. complete protein having all essential amino acids, with one protein: alpha-lactalbumin, containing relatively high levels of tryptophan, an amino acid which potentially stimulates satiety. Moreover, combined effects of elevated protein and lowered carbohydrate are investigated during body-weight loss in chapter 8; 'Elevated protein recommended and lowered carbohydrate additionally suggested for optimal weight loss', and during body-weight maintenance thereafter in chapter 9; 'Effect of carbohydrate content of protein leverage diets on efficacy of weight maintenance upon weight loss'. As individuals differ in their responses to dietary approaches to reduce their excess of fat mass and body weight and maintain the decreased body weight after successful body weight reduction, chapter 10; 'Relationship between perilipin gene polymorphisms and body weight and body composition during weight loss and weight maintenance' describes the influence of the genetic component of perilipin polymorphisms on the inter-individual results of a increased protein intake approach for successful body-weight loss and body-weight maintenance thereafter. Finally, chapter 11 generally discusses and summarizes the results of the above-described studies. 


\section{REFERENCES}

1. Pi-Sunyer FX. The obesity epidemic: pathophysiology and consequences of obesity. Obes Res 2002;10 Suppl 2:97S-104S.

2. Stunkard AJ. Current views on obesity. Am J Med 1996;100:230-6.

3. Pi-Sunyer FX. Medical hazards of obesity. Ann Intern Med 1993;119:655-60.

4. Baba NH, Sawaya S, Torbay N, Habbal Z, Azar S, Hashim SA. High protein vs. high carbohydrate hypoenergetic diet for the treatment of obese hyperinsulinemic subjects. Int J Obes Relat Metab Disord 1999;23:1202-6.

5. Wolfe RR. The underappreciated role of muscle in health and disease. Am J Clin Nutr 2006;84:475-82.

6. Harber MP, Schenk S, Barkan AL, Horowitz JF. Effects of dietary carbohydrate restriction with high protein intake on protein metabolism and the somatotropic axis. J Clin Endocrinol Metab 2005;90:5175-81.

7. Tappy L. Thermic effect of food and sympathetic nervous system activity in humans. Reprod Nutr Dev 1996;36:391-7.

8. Veldhorst M, Smeets A, Soenen S, et al. Protein-induced satiety: effects and mechanisms of different proteins. Physiol Behav 2008;94:300-7.

9. Smeets AJ, Soenen S, Luscombe-Marsh ND, Ueland O, Westerterp-Plantenga MS. Energy expenditure, satiety, and plasma ghrelin, glucagon-like peptide 1, and peptide tyrosine-tyrosine concentrations following a single high-protein lunch. J Nutr 2008;138:698-702.

10. Westerterp-Plantenga MS, Lejeune MP, Smeets AJ, Luscombe-Marsh ND. Sex differences in energy homeostatis following a diet relatively high in protein exchanged with carbohydrate, assessed in a respiration chamber in humans. Physiol Behav 2009;97:414-9.

11. Lejeune MP, Westerterp KR, Adam TC, Luscombe-Marsh ND, Westerterp-Plantenga MS. Ghrelin and glucagon-like peptide 1 concentrations, 24-h satiety, and energy and substrate metabolism during a high-protein diet and measured in a respiration chamber. Am J Clin Nutr 2006;83:89-94.

12. Lejeune MP, Kovacs EM, Westerterp Plantenga MS. Additional protein intake limits weight regain after weight loss in humans. Br J Nutr 2005;93:281-9.

13. Westerterp-Plantenga MS, Lejeune MP, Nijs I, van Ooijen M, Kovacs EM. High protein intake sustains weight maintenance after body-weight loss in humans. Int J Obes Relat Metab Disord 2004;28:57-64.

14. Mikkelsen PB, Toubro S, Astrup A. Effect of fat-reduced diets on 24-h energy expenditure: comparisons between animal protein, vegetable protein, and carbohydrate. Am J Clin Nutr 2000;72:1135-41.

15. Pannemans DL, Halliday D, Westerterp KR. Whole-body protein turnover in elderly men and women: responses to two protein intakes. Am J Clin Nutr 1995;61:33-8.

16. Pannemans DL, Halliday D, Westerterp KR, Kester AD. Effect of variable protein intake on whole-body protein turnover in young men and women. Am J Clin Nutr 1995;61:69-74.

17. Garlick PJ, McNurlan MA, Ballmer PE. Influence of dietary-protein intake on whole-body protein turnover in humans. Diabetes Care 1991;14:1189-98.

18. Robinson SM, Jaccard C, Persaud C, Jackson AA, Jequier E, Schutz Y. Protein turnover and thermogenesis in response to high-protein and high-carbohydrate feeding in men. Am J Clin Nutr 1990;52:72-80.

19. Gietzen DW, Hao S, Anthony TG. Mechanisms of food intake repression in indispensable amino acid deficiency. Annu Rev Nutr 2007;27:63-78.

20. Tome D. Protein, amino acids and the control of food intake. Br J Nutr 2004;92 Suppl 1:S27-30.

21. Pannemans DL, Wagenmakers AJ, Westerterp KR, Schaafsma G, Halliday D. Effect of protein source and quantity on protein metabolism in elderly women. Am J Clin Nutr 1998;68:1228-35.

22. Dangin M, Boirie $Y$, Guillet $C$, Beaufrere B. Influence of the protein digestion rate on protein turnover in young and elderly subjects. J Nutr 2002;132:3228S-33S. 
23. Dangin M, Boirie Y, Garcia-Rodenas C, et al. The digestion rate of protein is an independent regulating factor of postprandial protein retention. Am J Physiol Endocrinol Metab 2001;280:E340-8.

24. Boirie Y, Dangin M, Gachon P, Vasson MP, Maubois JL, Beaufrere B. Slow and fast dietary proteins differently modulate postprandial protein accretion. Proc Natl Acad Sci U S A 1997;94:14930-5.

25. Stryer L. Biochemistry. New York: W.H. Freeman and Company, 1988.

26. van Milgen J. Modeling biochemical aspects of energy metabolism in mammals. J Nutr 2002;132:3195-202.

27. Jungas RL, Halperin ML, Brosnan JT. Quantitative analysis of amino acid oxidation and related gluconeogenesis in humans. Physiol Rev 1992;72:419-48.

28. Koopman R, Saris WH, Wagenmakers AJ, van Loon LJ. Nutritional interventions to promote post-exercise muscle protein synthesis. Sports Med 2007;37:895-906.

29. Gaine PC, Pikosky MA, Martin WF, Bolster DR, Maresh CM, Rodriguez NR. Level of dietary protein impacts whole body protein turnover in trained males at rest. Metabolism 2006;55:501-7.

30. Sjodin AM, Forslund AH, Westerterp KR, Andersson AB, Forslund JM, Hambraeus LM. The influence of physical activity on BMR. Med Sci Sports Exerc 1996;28:85-91.

31. Welle S, Nair KS. Relationship of resting metabolic rate to body composition and protein turnover. Am J Physiol 1990;258:E990-8.

32. Soenen S, Westerterp-Plantenga MS. Proteins and satiety: implications for weight management. Curr Opin Clin Nutr Metab Care 2008;11:747-51.

33. Stock MJ. Gluttony and thermogenesis revisited. Int J Obes Relat Metab Disord 1999;23:110517.

34. Pullar JD, Webster AJ. The energy cost of fat and protein deposition in the rat. Br J Nutr 1977;37:355-63.

35. Skov AR, Toubro S, Ronn B, Holm L, Astrup A. Randomized trial on protein vs carbohydrate in ad libitum fat reduced diet for the treatment of obesity. Int $J$ Obes Relat Metab Disord 1999;23:528-36.

36. Due A, Toubro S, Skov AR, Astrup A. Effect of normal-fat diets, either medium or high in protein, on body weight in overweight subjects: a randomised 1-year trial. Int J Obes Relat Metab Disord 2004;28:1283-90.

37. Weigle DS, Breen PA, Matthys CC, et al. A high-protein diet induces sustained reductions in appetite, ad libitum caloric intake, and body weight despite compensatory changes in diurnal plasma leptin and ghrelin concentrations. Am J Clin Nutr 2005;82:41-8.

38. Dumesnil JG, Turgeon J, Tremblay A, et al. Effect of a low-glycaemic index--low-fat--highprotein diet on the atherogenic metabolic risk profile of abdominally obese men. Br J Nutr 2001;86:557-68.

39. Johnstone AM, Horgan GW, Murison SD, Bremner DM, Lobley GE. Effects of a high-protein ketogenic diet on hunger, appetite, and weight loss in obese men feeding ad libitum. Am J Clin Nutr 2008;87:44-55.

40. Bellissimo N, Desantadina MV, Pencharz PB, Berall GB, Thomas SG, Anderson GH. A comparison of short-term appetite and energy intakes in normal weight and obese boys following glucose and whey-protein drinks. Int J Obes (Lond) 2008;32:362-71.

41. Lacroix M, Gaudichon C, Martin A, et al. A long-term high-protein diet markedly reduces adipose tissue without major side effects in Wistar male rats. Am J Physiol Regul Integr Comp Physiol 2004;287:R934-42. 

NO DIFFERENCES IN SATIETY, OR ENERGY INTAKE FOLLOWING HFCS, SUCROSE, OR MILK PRELOADS

StiJn Soenen AND MARgriet S Westerterp-Plantenga AM J CLIN NUTR 2007;86:1586-94 


\section{ABSTRACT}

\section{Background}

It is unclear whether energy containing drinks, especially HFCS-sweetened soft drinks promote a positive energy balance and thereby play a role in the development of obesity.

\section{Objective}

To examine the satiating effects of HFCS and sucrose in comparison with milk and a diet drink.

\section{Design}

Satiety effects of four $800 \mathrm{~mL}$ drinks containing no energy or $1.5 \mathrm{MJ}$ from sucrose, HFCS, or milk were assessed; first in 15 men and 15 women (BMI $22.1 \pm 1.9 \mathrm{~kg} / \mathrm{m}^{2}$ ) according to visual analogue scales (VAS) and blood parameters, and second in 20 men and 20 women (BMI $22.4 \pm 2.1 \mathrm{~kg} / \mathrm{m}^{2}$ ) according to ingestion of a standardized ad libitum meal (granola cereal + yoghurt $10.1 \mathrm{~kJ} / \mathrm{g}$ ).

\section{Results}

At $50 \mathrm{~min}$ after the $1.5 \mathrm{MJ}$ preload-drinks, either containing sucrose, HFCS or milk $170 \%$ mm VAS changes in satiety were observed. GLP-1 $(\mathrm{p}<0.001)$ and ghrelin concentrations $(\mathrm{p}<0.05)$ changed accordingly. Compensatory energy intake after sucrose-, HFCS-containing preloads, or milk did not differ, and reached $30-45 \%$. Energy intake compensations were related to satiety $(\mathrm{r}=0.35, \mathrm{p}<0.05)$. No differences were present between the effects of sucrose- or HFCS-containing drinks, in changes in VAS, insulin, glucose, GLP-1, and ghrelin concentrations. Changes in appetite VASratings were a function of changes in GLP-1, ghrelin and insulin hormones and glucose concentrations.

\section{Conclusion}

Energy balance consequences of HFCS-sweetened soft drinks are not different from those of other iso-energetic drinks e.g. a sucrose-drink or milk.

\section{Keywords}

GLP-1, ghrelin, insulin, glucose, energy intake 


\section{INTRODUCTION}

Trends in overweight are consistent with increased energy intake over recent decades (1). The upward shift in energy intake may partly consist of consumption of soft drinks (2-5). Increased soft drink consumption has coincided with the increase in prevalence of overweight and obesity $(6,7)$ over the past three decades in the US $(8-10)$. In the 1970 's, the food industry in the US introduced High Fructose Corn Syrup (HFCS) sweetener as a substitute for sucrose (11). It has been suggested that the obesity epidemic may have been aggravated by the increase in HFCS consumption (12).

Drinking HFCS-sweetened soda was reported to increase energy intake and body weight (13). However, several studies have reported that fructose, when consumed alone, reduced subsequent energy intake equally in some (14-16) or significantly more in other studies (17-19) compared to a monosaccharide glucose preload. Yet, it should be noted that the principal sweetener in soft drinks in the US, HFCS, is not pure fructose but a mixture of fructose and glucose $(55 \% / 45 \%)$. Factors that may account for the different effects of fructose alone or a mix of fructose and glucose are its gastrointestinal effects and absorption characteristics $(20,21)$.

In addition to the composition of ingested carbohydrates, the physical state of intake may be important in influencing subsequent energy intake compensation. Compensatory dietary responses to energy containing beverages have been found to be less precise than those to iso-energetic solid loads $(22,23)$. Thus, fluid carbohydrates such as soft drinks could increase the risk of excess total energy intake. An effect of soft drink consumption, e.g. of sucrose compared to artificial sweeteners, on weight gain and obesity has been found in children (24-26), adolescents (27), and adults (28, 29). Based on those studies, it is suggested that carbohydrates in liquid form promote a positive energy balance and therefore contribute to the development of obesity.

Compensation for energy intake from drinks by a change in energy intake at the subsequent meal depends on the moment in time of preload ingestion. Time delay between preload and test meal interferes with the outcome of preload studies (30-32).

The objective of the present study was to examine if there is a difference in response between an HFCS-sweetened and a sucrose-sweetened iso-energetic, isovolumetric orange-flavored preload compared with a no-energy control. A milk preload was used to compare the soft drinks with another type of liquid preload. The responses were measured as the appetite profile using visual analogue scales (VAS) and as a possible change in the 'satiety' hormones: glucagon-like peptide 1 (GLP-1), insulin, ghrelin, and glucose in a first study. Moreover, the latest time point after ingestion when relevant differences in satiety scores or satiety hormone concentrations still were present, was determined as the moment in time for the subsequent test meal. In a second study, possible compensation in energy intake during an ad libitum subsequent meal was determined. The studies were conducted in Europe, so subjects had a negligible history of consuming HFCS-containing products.

\section{METHODS}

\section{Subjects}

Subjects were recruited by means of an advertisement in local newspapers and on notice boards at Maastricht University. Subjects who were willing to participate in the 
study were subsequently screened, by means of a detailed medical history and a physical examination. All subjects were in good health, normotensive, non-smokers, non-restrained eaters, regular breakfast consumers, at most moderate alcohol users, had a stable body weight ( $<2 \mathrm{~kg}$ change over at least the last two months) and did not use prescription medication. Excluded from the study were athletes, training more than 10 hours per week. Thirty subjects participated in the first study, forty in the second study, with equal numbers of men and women. Subject characteristics are given in Table 2.1. Subjects were requested to maintain their customary level of physical activity and normal dietary habits, and not to gain or lose weight for the duration of the study. All subjects gave written informed consent, and the experimental protocol was approved by the local Medical Ethics Committee of the University of Maastricht.

Table 2.1. Subject characteristics

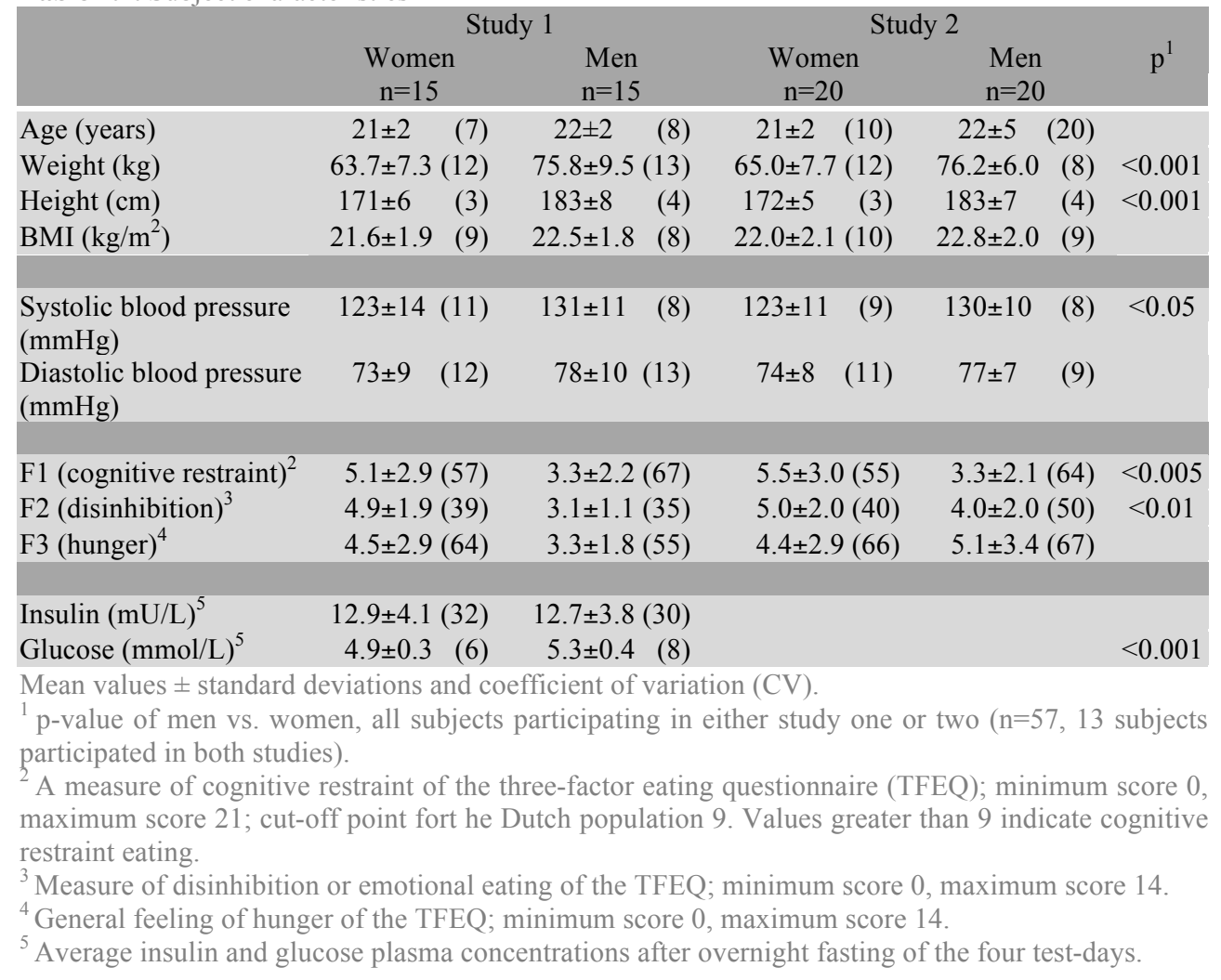

\section{Study design}

A within-subject design was used, with each subject returning for four separate test days, at least one week apart. The preloads were offered blindly and in randomized order to avoid the order-of-treatment effect. To analyze possible differences in the appetite profile, visual analogue scale (VAS) ratings and blood samples for the analysis of GLP-1, ghrelin, insulin and glucose were collected before and after preload consumption in the first study. The last moment in time at which relevant differences in satiety were present was determined, in order to decide on the timing of the test meal in 
the second study. The second study consisted of the same preload consumptions, with VAS ratings of the appetite profile before and after the preload and a test meal at the relevant moment in time, as defined by the first study.

\section{Anthropometry}

Body weight was determined during screening and on each test day, using a digital balance (Chyo-MW-150K, Chyo, Japan; weighing accuracy $0.02 \mathrm{~kg}$ ) with subjects in underwear, in the fasted state and after voiding their bladder. Height was measured to the nearest $0.1 \mathrm{~cm}$ using a wall-mounted stadiometer (Seca, model 220, Hamburg, Germany). Body mass index (BMI) was calculated by dividing body weight by height squared $\left(\mathrm{kg} / \mathrm{m}^{2}\right)$. Systolic and diastolic blood pressures were recorded during screening, using an automatic blood pressure monitor (OSZ 5 easy; Spreidel \& Keller $\mathrm{GmBH}$ and Co. KG, Jungingen, Germany).

Table 2.2. Energy and macronutrient composition of the four preloads and the meal

\begin{tabular}{|c|c|c|c|c|c|c|c|c|c|}
\hline & \multirow{2}{*}{\multicolumn{2}{|c|}{$\begin{array}{c}\text { Sucrose }^{2} \\
\text { containing preloac } \\
\text { kJ }\end{array}$}} & \multicolumn{2}{|c|}{$\begin{array}{l}\mathrm{HFCS}^{3} \\
\text { ntaining preload }\end{array}$} & \multicolumn{2}{|c|}{$\begin{array}{l}\text { Milk } \\
\text { preload }\end{array}$} & \multirow{2}{*}{$\begin{array}{l}\text { Diet } \\
\text { preload } \\
\mathrm{kJ}\end{array}$} & \multirow[b]{2}{*}{$\mathrm{kJ} / 100 \mathrm{~g}$} & \multirow[b]{2}{*}{$\% 4$} \\
\hline & & & $\mathrm{kJ}$ & $\%^{4}$ & $\mathrm{~kJ}$ & $\%{ }^{4}$ & & & \\
\hline Carbohydrate & 1500 & & 1500 & & 632 & & 0 & 554 & 55 \\
\hline Glucose & 960 & 64 & 615 & 41 & 0 & & 0 & & \\
\hline Fructose & 540 & 36 & 885 & 59 & 0 & & 0 & & \\
\hline Lactose & 0 & & 0 & & 632 & 42 & & & \\
\hline Protein & 0 & & 0 & & 442 & 30 & 2 & 80 & 8 \\
\hline Fat & 0 & & 0 & & 426 & 28 & 0 & 378 & 37 \\
\hline Energy $(\mathrm{kJ})$ & 1500 & & 1500 & & 1500 & & 2 & 1012 & \\
\hline Volume $(\mathrm{mL})$ & 800 & & 800 & & 800 & & 800 & & \\
\hline Energy density $(\mathrm{kJ} / \mathrm{g})$ & 1.9 & & 1.9 & & 1.9 & & 0 & 10.1 & \\
\hline \multicolumn{10}{|c|}{$\begin{array}{l}1 \text { The test meal consisted of a granola cereal with yoghurt. } \\
266 \% \text { sucrose and } 34 \% \text { glucose syrup ( } 91 \% \text { glucose and } 9 \% \text { fructose). } \\
355 \% \text { fructose and } 45 \% \text { glucose syrup ( } 91 \% \text { glucose and } 9 \% \text { fructose). } \\
{ }^{4} \text { Energy percentage of the energy containing macronutrients. }\end{array}$} \\
\hline Preloads & & & & & & & & & \\
\hline
\end{tabular}

The four beverages were a beverage containing sucrose, one containing HFCS, milk, and a diet drink. Energy content and macronutrient composition of the four beverages are specified in Table 2.2. All four drinks were iso-volumetric and had a volume of $800 \mathrm{~mL}$. The energy drinks were iso-energetic and provided 1.5 MJ. The diet drink had an energy content of $0.2 \mathrm{MJ}$. The drinks containing sucrose, HFCS and the diet drink were orange flavored custom-made beverages; they were equally sweet. The sucrose containing preload had the same consistency as a commercially available sucrosesweetened drink containing $450 \mathrm{~g}$ sucrose and $236 \mathrm{~g}$ glucose syrup (91\% glucose and $9 \%$ fructose). The HFCS-containing preload had the consistency of a commercially available HFCS-sweetened drink containing 55\% fructose and $45 \%$ glucose syrup (91\% glucose and $9 \%$ fructose). The diet preload consisted of the sweeteners aspartame, acesulfame-K and sodium cyclamate. Additionally, all three preloads contained water, citric acid, orange flavoring, coloring E160, preservative E202 and 
antioxidant E300. Drinks were prepared by diluting $133 \mathrm{~mL}$ syrup with $667 \mathrm{~mL}$ water. All four beverages were served chilled at $8^{\circ} \mathrm{C}$.

\section{Test meal}

The test meal that was served in the second study consisted of a granola cereal with yoghurt. The nutrient composition of the test meal is shown in Table 2.2. Subjects were requested to continue eating until they felt comfortably full. All foods were preweighed at the time of serving and plate waste was collected and weighed.

\section{Attitude towards eating}

The subjects' attitude towards eating was determined during screening using a validated Dutch translation of the Three Factor Eating Questionnaire (TFEQ) $(33,34)$. Table 2.1 shows the scores on cognitive restrained and unrestrained eating behavior (F1), emotional eating and disinhibition of control (F2), and subjective feeling of hunger (F3).

\section{Appetite profile}

The subjects' feelings of hunger, satiety, fullness, prospective food and drink consumption, and desire to eat and drink were scored on anchored $100 \mathrm{~mm}$ VAS at 6 different half-hour time points in study 1 , and 7 in study 2 . The scale ranged from 'not at all' on the left to 'extremely' on the right. Subjects were instructed to mark, with a single vertical line, a point where the length of the line matched their subjective sensation. All VAS's were provided on a separate form at each time point, and were collected immediately after they had been completed.

\section{Taste perception and hedonics}

Subjects rated their taste perception and hedonics for the four test drinks on anchored $100 \mathrm{~mm}$ VAS during screening and at the first and last sip of the beverage consumed during each test day (Table 2.3). The following scales had to be completed: how sweet/sour/bitter/salt is the drink; how rich/creamy/fresh is the flavor of the drink; how pleasant is the drink now in your mouth.

Table 2.3. Perception of taste characteristics

$\begin{array}{lcccc} & \begin{array}{c}\text { Sucrose } \\ \text { containing preload }\end{array} & \begin{array}{c}\text { HFCS } \\ \text { containing preload }\end{array} & \begin{array}{c}\text { Milk } \\ \text { preload }\end{array} & \begin{array}{c}\text { Diet } \\ \text { preload }\end{array} \\ \text { Sweetness } & 66 \pm 14^{\mathrm{a}} & 70 \pm 17^{\mathrm{a}} & 25 \pm 22^{\mathrm{b}} & 52 \pm 22^{\mathrm{c}} \\ \text { Sourness } & 20 \pm 20^{\mathrm{a}, \mathrm{b}} & 29 \pm 23^{\mathrm{a}, \mathrm{c}} & 13 \pm 16^{\mathrm{b}} & 37 \pm 21^{\mathrm{c}} \\ \text { Bitterness } & 12 \pm 12^{\mathrm{a}} & 15 \pm 17^{\mathrm{a}, \mathrm{c}} & 12 \pm 17^{\mathrm{a}, \mathrm{b}} & 23 \pm 21^{\mathrm{c}} \\ \text { Saltiness } & 8 \pm 10^{\mathrm{a}} & 8 \pm 12^{\mathrm{a}} & 10 \pm 15^{\mathrm{a}} & 14 \pm 17^{\mathrm{a}} \\ \text { Richness } & 44 \pm 23^{\mathrm{a}} & 50 \pm 24^{\mathrm{a}} & 68 \pm 16^{\mathrm{b}} & 41 \pm 25^{\mathrm{a}} \\ \text { Creaminess } & 13 \pm 16^{\mathrm{a}} & 14 \pm 14^{\mathrm{a}} & 77 \pm 13^{\mathrm{b}} & 13 \pm 15^{\mathrm{a}} \\ \text { Refreshing } & 67 \pm 14^{\mathrm{a}} & 66 \pm 14^{\mathrm{a}} & 41 \pm 20^{\mathrm{b}} & 61 \pm 19^{\mathrm{a}} \\ \text { Pleasantness } & 70 \pm 14^{\mathrm{a}} & 68 \pm 15^{\mathrm{a}} & 52 \pm 21^{\mathrm{b}} & 50 \pm 23^{\mathrm{b}} \\ \text { Intensness } & 51 \pm 19^{\mathrm{a}} & 59 \pm 21^{\mathrm{a}} & 50 \pm 26^{\mathrm{a}} & 48 \pm 22^{\mathrm{a}}\end{array}$

Mean values \pm standard deviations.

a,b,c $\mathrm{p}<0.05$; different letter indicates significant difference between the perceived taste characteristic of the preloads. 


\section{Blood samples}

Venous blood samples were taken at five time points; one fasting sample at baseline before and 4 samples at 15, 30,60 and 120 minutes after preload consumption. After each blood collection, the intravenous cannula was rinsed using $0.9 \%$ sterile sodium chloride solution containing $1 \%$ heparin. Blood samples were taken to determine concentrations of plasma GLP-1, ghrelin, insulin and glucose. The blood samples were collected in tubes containing EDTA to prevent clotting. Blood samples for GLP-1 analysis were collected in ice-chilled syringes containing $20 \mu \mathrm{l}$ of dipeptidyl peptidaseIV (DPP-IV) inhibitor (Linco Research Inc., St. Charles, Missouri, USA) to prevent degradation. Plasma was obtained by centrifugation $\left(1500^{*} \mathrm{~g}, 10 \mathrm{~min}, 4^{\circ} \mathrm{C}\right)$, frozen in liquid nitrogen and stored at $-80^{\circ} \mathrm{C}$ until analysis. Plasma ghrelin samples were mixed with $\mathrm{HCl}$, methanol and phenylmethanesulfonyl fluoride (PMSF, Sigma-Aldrich, The Netherlands). Plasma concentrations of active ghrelin were measured by radioimmunoassay (Linco Research Inc., St. Charles, Missouri, USA) and those of active GLP-1 by ELISA (EGLP-35K; Linco Research Inc., ST Charles, Missouri, USA). Insulin samples were analyzed with a RIA kit (Linco Research Inc., St. Charles, Missouri, USA), and glucose samples using a hexokinase method (ABX Diagnostics, Montpellier, France).

\section{Test day procedure}

After an overnight fast, the subjects arrived at the laboratory at 08:15 AM. Subjects were asked to keep their habitual evening meals, to refrain from alcohol or indulge in strenuous exercise, and to refrain from eating and drinking after 11:00 PM on the day before each test. Body weight was measured and an intravenous Venflon cannula (Baxter BV, Utrecht, The Netherlands) was inserted in the antecubital vein to enable blood sampling (study 1). Subjects remained seated in comfortable chairs separated by large room dividers with minimal disturbance from the investigators throughout the experimental session. During each test day, subjects were isolated from time cues to eliminate as much as possible habitual (time-determined) meal patterns; no watches, clocks or radios were present in the test room, and research staff did not make timerelated statements. Subjects were allowed to stretch their legs, use the bathroom, read, listen to music or watch movies, but not whilst drinking the preload or eating the meal (study 2). At 09:00 AM, after collection of the baseline appetite profile and blood sample, the subjects received one of the four liquid preloads. Preloads had to be consumed entirely within 10 minutes. Preloads were accompanied by a VAS of taste perception and hedonics at the first and last sip of the beverage. Blood sampling in study 1 was repeated at 15, 30, 60 and 120 minutes after preload consumption and appetite profile at 20,50,80, 110 and 140 (last time point only in study 2) minutes after preload consumption. The catheter was removed after the last blood sample had been taken. The meal in study 2 was served 50 minutes after the preload consumption based on the VAS ratings or differences in increases of satiety hormones of the first study.

\section{Statistical analysis}

Data are presented as means with standard deviations or with standard errors. VAS ratings were measured in millimeters from the left end of the scale. The changes in 
concentrations of the hormones from baseline and changes from baseline in VAS ratings of the appetite profile were compared by ANOVA, repeated measures ANOVA (analysis of change score) and ANCOVA with the baseline values as covariate. Since the experiment was fully randomized with one week wash-out between the tests (i), and there was no significant difference between the baseline scores (ii) and the washout period was longer than the actual experiment (iii), it is more appropriate to use the analysis of change score from baseline with a $\mathrm{n}$-factor repeated measures (ANOVA) instead of ANCOVA (35). An ANCOVA may give bias due to the "weight" of the baseline values (35). Post-hoc analysis was carried out with a Fisher PLSD, a Sheffe F-test or a Tukey test. Taste perception and energy intake after the preloads were compared by ANOVA. Differences in responses between the drinks containing sucrose and HFCS were compared with a two-tailed paired Student T-test. Gender differences were assessed using ANOVA. Time by gender interactions were assessed using repeated measures ANOVA, and time by treatment by gender interactions using Multivariate ANOVA with preload condition and gender as fixed factors. Changes in the desire to eat from baseline were analyzed as a function of changes in concentrations of hormones and glucose from baseline using regression analysis. Compensation was calculated as a difference between energy intake after the diet preload and energy intake after any of the energy preloads as a percentage of the energy content of these preloads. Overconsumption was calculated as a difference between total energy intake after any of the energy preloads and total energy intake after the diet preload as a percentage of energy intake after the diet preload. All analyses were performed with the Statistical Package for the Social Sciences (SPSS) version 11.0.3 for Macintosh OS $\mathrm{X}$. Differences were regarded as significant if $\mathrm{p}<0.05$.

Table 2.4. Satiety $(\triangle \mathrm{AUC})$ as a function of hormones GLP-1, ghrelin and insulin ( $\triangle \mathrm{AUC})$ and correlations between hormones GLP-1, ghrelin and insulin ( $\triangle \mathrm{AUC})$, and glucose $(\triangle \mathrm{AUC})$

\begin{tabular}{|c|c|c|c|c|c|c|c|c|}
\hline \multirow[b]{2}{*}{ Preload } & \multirow[b]{2}{*}{$\mathrm{n}$} & & \multicolumn{2}{|c|}{ GLP-1 } & \multicolumn{2}{|c|}{ ghrelin } & \multicolumn{2}{|c|}{ insulin } \\
\hline & & & r & $\mathrm{p}$ & $\mathrm{r}$ & $\mathrm{p}$ & $\mathrm{r}$ & $\mathrm{p}$ \\
\hline all & 120 & Satiety & 0.253 & $<0.01$ & & & 0.241 & $<0.05$ \\
\hline sucrose & 30 & & 0.382 & $<0.05$ & & & 0.370 & $<0.05$ \\
\hline HFCS & 30 & & 0.429 & $<0.05$ & -0.407 & $<0.05$ & & \\
\hline milk & 30 & & & & 0.423 & $<0.05$ & & \\
\hline diet & 30 & & & & & & & \\
\hline all & 120 & GLP-1 & - & - & - & - & - & - \\
\hline & & Ghrelin & & & & & - & - \\
\hline & & Insulin & 0.36 & $<0.001$ & -0.19 & $<0.05$ & 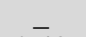 & - \\
\hline & & Glucose & & & -0.22 & $<0.05$ & 0.49 & $<0.001$ \\
\hline
\end{tabular}

\section{RESULTS}

\section{Perception of taste characteristics}

Drinks containing sucrose or HFCS ( $800 \mathrm{~mL}, 1.5 \mathrm{MJ})$ did not differ in taste perception or palatability. The milk preload $(800 \mathrm{~mL}, 1.5 \mathrm{MJ})$ was perceived as less sweet, sour, refreshing and pleasant $(\mathrm{p}<0.01)$, and more rich and creamy compared to preloads containing sucrose or HFCS $(p<0.005)$. Diet preload $(800 \mathrm{~mL}, 2 \mathrm{~kJ})$ was perceived as less pleasant and less sweet than preloads containing sucrose or HFCS $(\mathrm{p}<0.001)$ 
(Table 2.3). Taste perception did not differ between genders. Perceptions of thirst after preloads did not differ between the preloads. Thirst was significantly more reduced in women compared to men (AUC change from baseline: $-18 \pm 9$ vs. $-31 \pm 16 \mathrm{~mm} \mathrm{VAS} / \mathrm{min}$ respectively, $\mathrm{p}<0.05)$. Determination of the moment in time to serve the test-meal in study 2 .

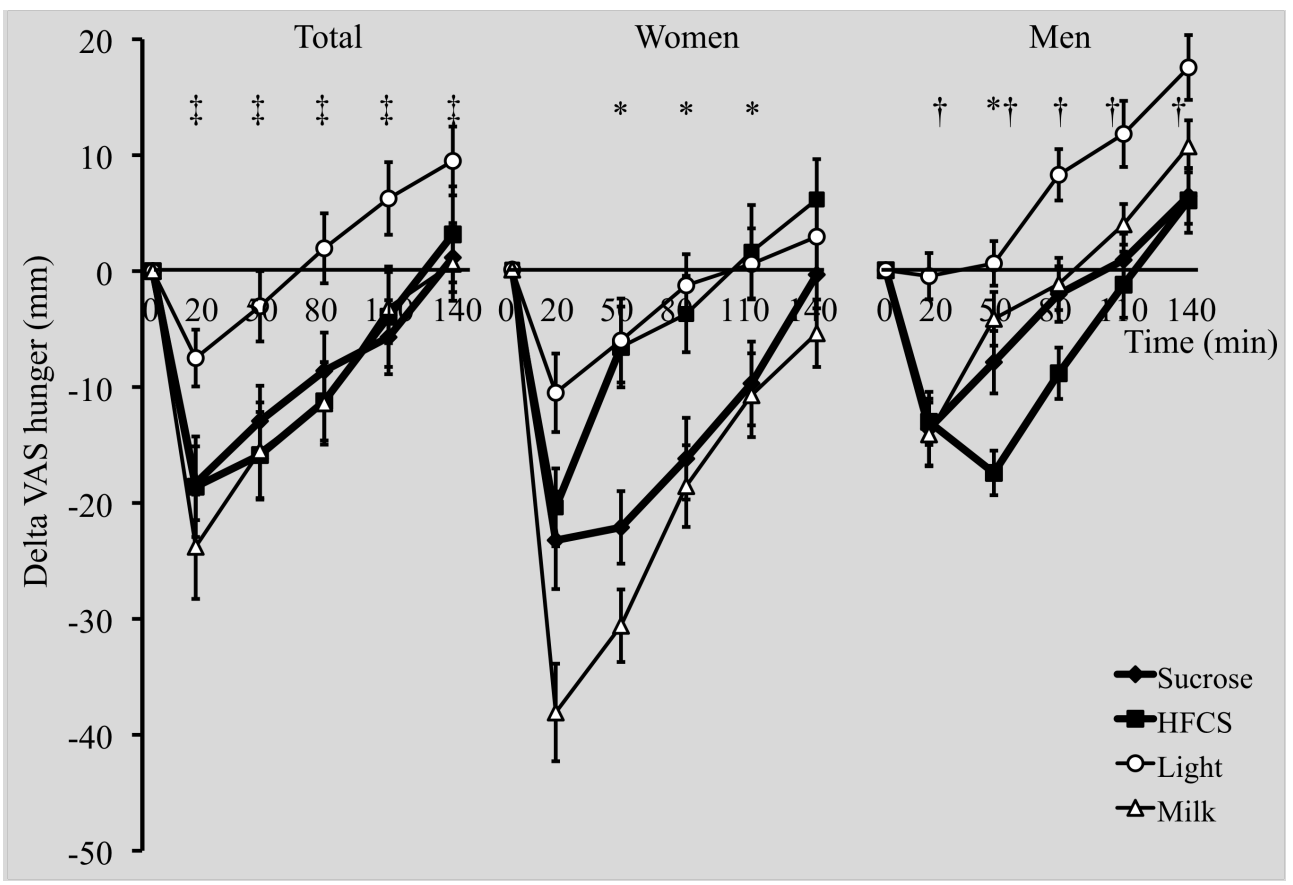

Figure 2.1. Mean and SEM change in hunger $(\mathrm{mm})$ of the total group $(n=30)$, and men $(n=15)$ and women $(n=15)$ separately as a function of preload condition (study 1$)$.

Significant difference; $\mathrm{p}<0.05$ (Multivariate ANOVA) time by treatment by gender interaction; $\$ \mathrm{p}<0.05$ (repeated measures ANOVA) between the diet preload and the sucrose- and HFCScontaining, and milk preload; $\uparrow \mathrm{p}<0.005$ (ANOVA) between the diet preload and the sucrose- and HFCS-containing preload; ${ }^{*} \mathrm{p}<0.05$ (two tailed paired Student t-test) between the sucrose- and HFCScontaining preload.

In study 1 we determined the moment in time to serve the meal in study 2 . The right moment was determined by identifying the moment in time when the mean difference in responses on preloads containing sucrose or HFCS was statistically significant. This moment appeared to be at 50 minutes after the preload consumption. This moment in time was underscored by the following. Although preloads containing sucrose or HFCS did not differ in satiety and hunger ratings in the total group (Figure 2.1), the reduction of hunger relative to baseline after a preload differed significantly between men and women $(\mathrm{p}<0.05)$. Men showed a significantly greater reduction of hunger after the preload containing HFCS than after the preload containing sucrose at time-point 50 minutes $(-8 \pm 14$ vs. $-17 \pm 15 \mathrm{~mm}$ VAS respectively, $\mathrm{p}<0.05$ ), while women showed the opposite. Women had a significantly greater reduction of hunger ratings at 50,80 and 110 minutes, with the maximal difference at 


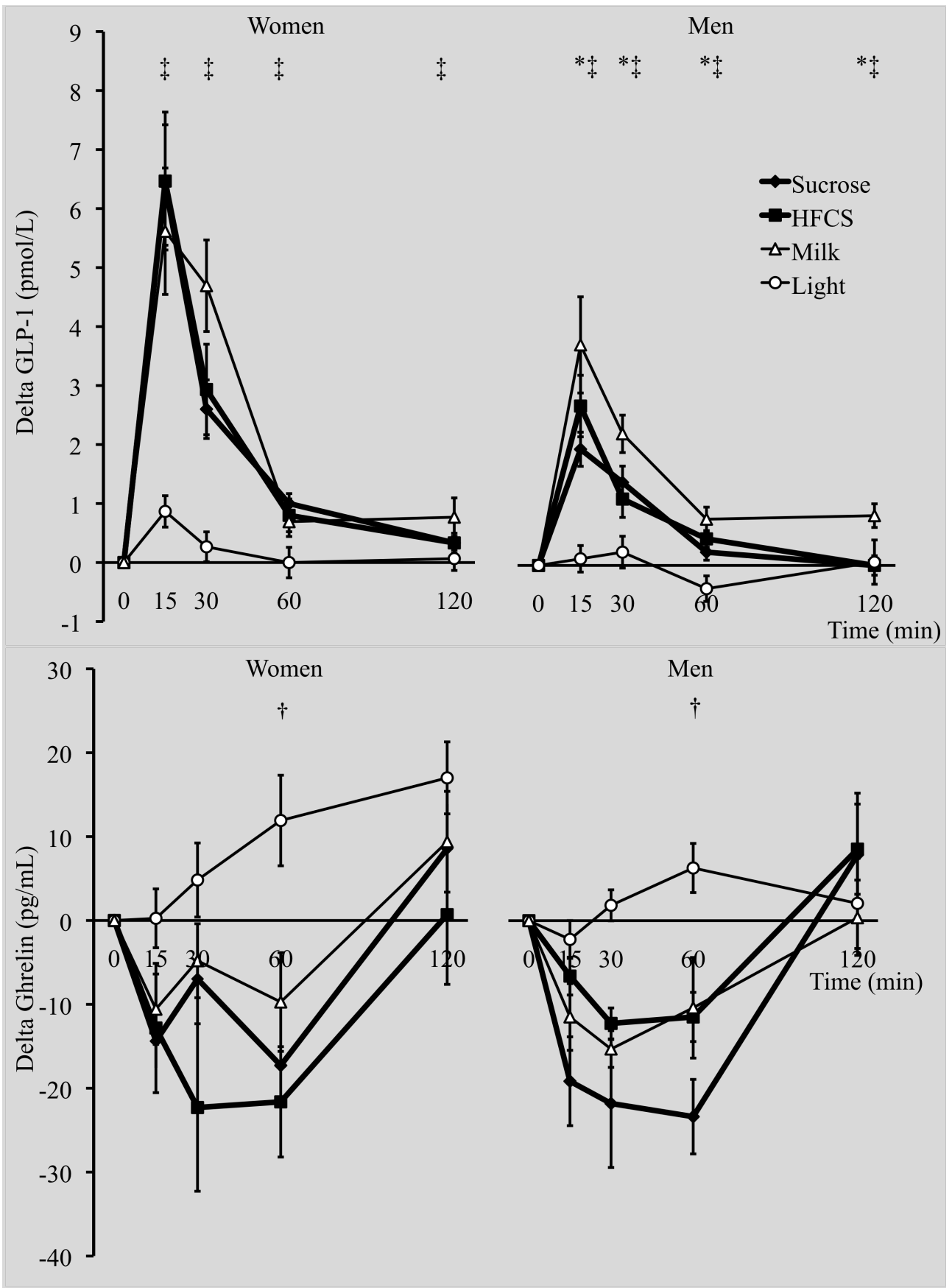



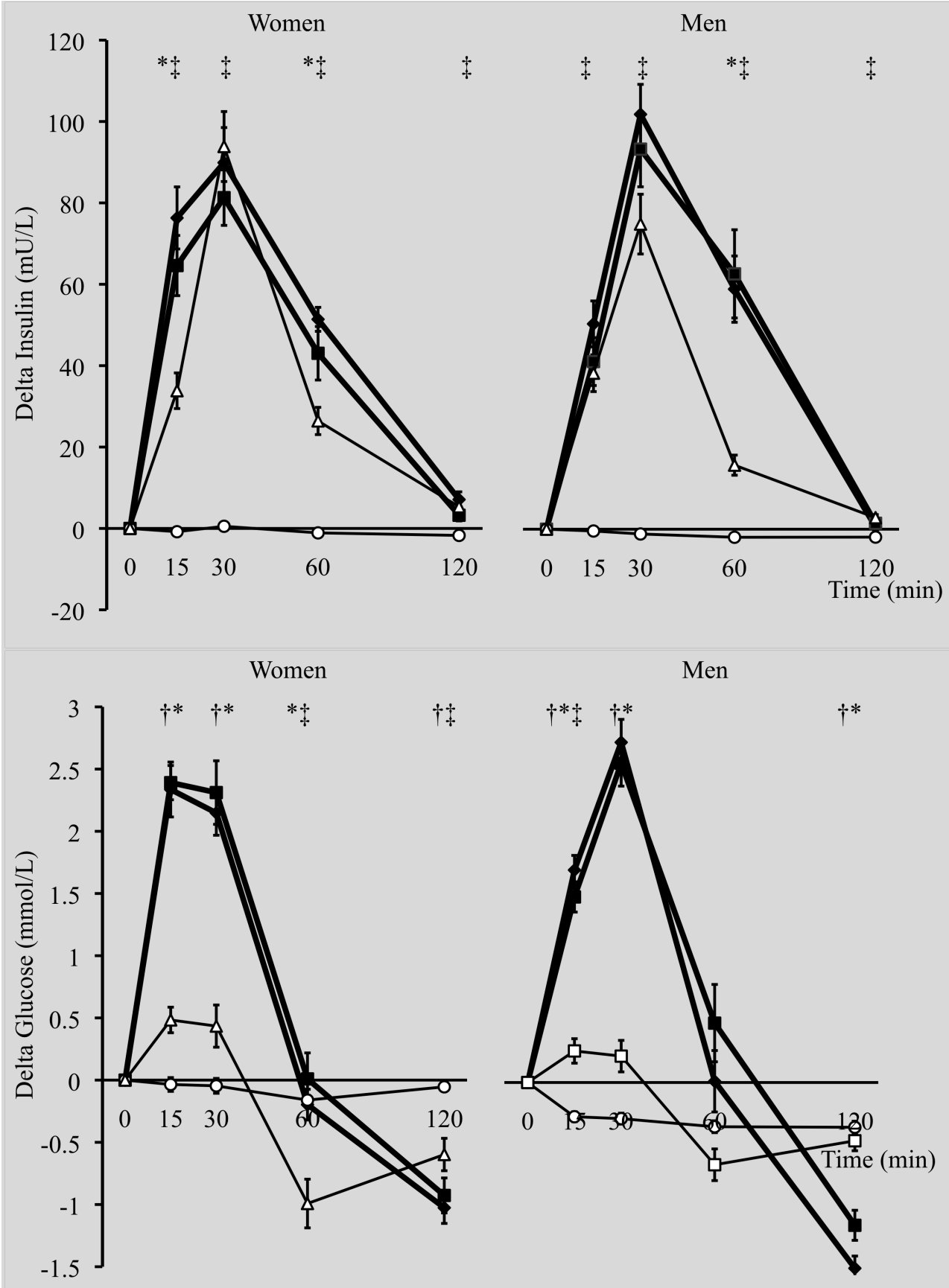
Figure 2.2a. Mean and SEM change in GLP-1 (pmol/L) of men $(n=15)$ and women $(n=15)$ as a function of preload condition.

Significant difference; $\$ \mathrm{p}<0.005$ (ANOVA) between the diet preload and the sucrose- and HFCScontaining, and milk preload; ${ }^{*} \mathrm{p}<0.05$ (ANOVA) between the milk preload and the sucrose- and HFCS-containing preload; $\mathrm{p}<0.001$ (repeated measures ANOVA) time by treatment interaction between the diet preload and the sucrose- and HFCS-containing, and milk preload; $\mathrm{p}<0.01$ (repeated measures ANOVA) time by gender interaction.

Figure 2.2b. Mean and SEM change in ghrelin $(\mathrm{pg} / \mathrm{mL})$ of men $(n=15)$ and women $(n=15)$ as a function of preload condition.

Significant difference; $\uparrow \mathrm{p}<0.05$ (ANOVA) between the diet preload and the sucrose- and HFCScontaining preload; $\mathrm{p}<0.05$ (repeated measures ANOVA) time by treatment interaction between the diet preload and the sucrose- and HFCS-containing preload; time by gender interaction was not significant (repeated measures ANOVA).

Figure 2.2c. Mean and SEM change in insulin (mU/L) of men $(n=15)$ and women $(n=15)$ as a function of preload condition.

Significant difference; $\$ \mathrm{p}<0.001$ (ANOVA) between the diet preload and the sucrose- and HFCScontaining, and milk preload; ${ }^{*} \mathrm{p}<0.05$ (ANOVA) between the milk preload and the sucrose- and HFCS-containing preload; $\mathrm{p}<0.001$ (repeated measures ANOVA) time by treatment interaction between the diet preload and the sucrose- and HFCS-containing, and milk preload; time by gender interaction was not significant (repeated measures ANOVA).

Figure 2.2d. Mean and SEM change in glucose $(\mathrm{mmol} / \mathrm{L})$ of men $(\mathrm{n}=15)$ and women $(\mathrm{n}=15)$ as a function of preload condition.

Significant difference; $\$ \mathrm{p}<0.05$ (ANOVA) between the diet and the milk preload; $* \mathrm{p}<0.001$ (ANOVA) between the milk preload and the sucrose- and HFCS-containing preload; $\uparrow \mathrm{p}<0.001$ (ANOVA) between the diet preload and the sucrose- and HFCS-containing preload; $p<0.001$ (repeated measures ANOVA) time by treatment interaction between the diet preload and the sucroseand HFCS-containing preload; $\mathrm{p}<0.001$ (repeated measures ANOVA) time by treatment interaction between the milk preload and the sucrose- and HFCS-containing preload; $\mathrm{p}<0.01$ (repeated measures ANOVA) time by gender interaction.

50 minutes $(-24 \pm 18$ vs. $-7 \pm 19$ mm VAS, $p<0.05)$, after consumption of the preload containing sucrose compared to HFCS. Thus the adequate moment in time to serve the test meal in study 2 was 50 minutes, as underscored by the significant treatment by gender interaction at 50 minutes $(\mathrm{p}<0.05)$. Differences in VAS ratings between treatments differed in men and women. This moment in time was not supported by differences in concentrations in GLP-1, ghrelin, insulin, or glucose relative to baseline, as illustrated in Figure 2.2. However, changes in VAS ratings relative to baseline were a function of changes in concentrations of the hormones GLP-1, ghrelin and insulin relative to baseline values, as shown in Table 2.4. VAS appetite ratings stepwise multiple linear regression analysis showed that change in GLP-1 and insulin independently predicted change in satiety $(\mathrm{r}=-0.242, \mathrm{p}=0.014 ; \mathrm{r}=-0.239, \mathrm{p}=0.029$, respectively). Moreover, glucose and insulin concentrations were related after preload consumption, as expected, and GLP-1 and ghrelin concentrations were related to insulin concentrations. GLP-1 and ghrelin concentrations were not related to each other. Furthermore, the determination of the adequate moment in time to serve the meal in study 2 was underscored by the decline in glucose concentrations.

\section{Energy containing preloads vs. diet preload}

Meal size and energy intake were significantly lower after consumption of preloads containing sucrose or HFCS, or the milk preload compared to the diet preload 
(Table 2.5). This was supported by the significantly higher GLP-1 and insulin concentrations (Figure 2.2, $<<0.001$ ) and significantly lower ghrelin concentrations $(\mathrm{p}<0.05)$ and hunger (Figure 2.1, $\mathrm{p}<0.05$ ) after the energy containing preloads compared to after the diet preload. Thus, less energy was consumed after consumption of an energy drink compared to a drink designed to not deliver energy. Total energy intake (preload + meal) with the energy containing preloads was significantly higher than total energy intake with the diet preload (Table 2.5). Therefore, during the meal, energy intake was only partly compensated. Compensation for energy intake from the preloads containing sucrose or HFCS, or from the milk preload did not differ significantly, and ranged from $30-45 \%$. Energy consumed after preloads, compensation and overconsumption differed significantly between men and women $(p<0.01)$. This gender difference is supported by the significant time by gender interactions for glucose and GLP-1 concentrations $(\mathrm{p}<0.01)$. Compared to women, men showed lower GLP-1 concentrations at baseline $(\mathrm{p}<0.05)$ and a smaller change in GLP1 concentration from baseline after preload consumption $(\mathrm{p}<0.01)$. Appetite ratings after drink consumption declined significantly more in women than in men $(p<0.05)$. Declines in hunger scores were not different among the 4 conditions after ingestion of the meals.

Table 2.5. Energy intake of the meal and the meal + preload, compensation, and overconsumption

\begin{tabular}{|c|c|c|c|c|c|}
\hline & & $\begin{array}{l}\text { Meal*\# } \\
(\mathrm{kJ})\end{array}$ & $\begin{array}{l}\text { Preload }+ \text { meal*\#\#\# }( \\
\quad(\mathrm{kJ})\end{array}$ & $\begin{array}{l}\text { Compensation* } \\
(\%)\end{array}$ & $\begin{array}{l}\text { Overconsumption* } \\
(\%)\end{array}$ \\
\hline \multirow{2}{*}{$\begin{array}{l}\text { Sucrose } \\
\text { containing preload }\end{array}$} & Women & $1742 \pm 730$ & $3215 \pm 730$ & $37 \pm 37$ & $53 \pm 53$ \\
\hline & Men & $2372 \pm 794$ & $3845 \pm 794$ & $53 \pm 47$ & $29 \pm 30$ \\
\hline \multirow{2}{*}{$\begin{array}{l}\text { HFCS } \\
\text { containing preload }\end{array}$} & Women & $1873 \pm 868$ & $3347 \pm 868$ & $28 \pm 42$ & $57 \pm 50$ \\
\hline & Men & $2335 \pm 786$ & $3808 \pm 786$ & $55 \pm 54$ & $29 \pm 34$ \\
\hline \multirow[t]{2}{*}{ Milk preload } & Wom & $1945 \pm 756$ & $3441 \pm 756$ & $24 \pm 42$ & $64 \pm 60$ \\
\hline & Men & $2626 \pm 880$ & $4122 \pm 880$ & $36 \pm 55$ & $37 \pm 34$ \\
\hline \multirow{2}{*}{ Diet preload } & Wom & $2290 \pm 773$ & $2292 \pm 773$ & & \\
\hline & Men & $3148 \pm 984$ & $3150 \pm 984$ & & \\
\hline \multicolumn{6}{|c|}{ Mean values \pm standard deviations $(n=40)$. } \\
\hline \multirow{3}{*}{\multicolumn{6}{|c|}{$\begin{array}{l}\text { Compensation }=\left(\mathrm{EI}_{\text {diet }}-\mathrm{EI}_{\text {after any preload }}\right) \text { as a } \% \text { of the preload. } \\
\text { Overconsumption }=\left(\text { total } \mathrm{EI}_{\text {after any preload }}-\text { total } \mathrm{Ei}_{\text {diet }}\right) \text { as a } \% \text { of } \mathrm{EI}_{\text {diet }} \text {. } \\
* \mathrm{p}<0.05 ; \text { men vs. women, treatment by gender interaction was not } \mathrm{s}\end{array}$}} \\
\hline & & & & & \\
\hline & & & & & \\
\hline \multicolumn{6}{|c|}{$\begin{array}{l}\mathrm{p}<0.05 \text {, \#\#\# } \mathrm{p}<0.001 \text {; treatment between groups, diet preload vs. sucrose- and HFCS-containing } \\
\text { and milk preload. }\end{array}$} \\
\hline
\end{tabular}

Compensation after the energy containing preloads was a function of the magnitude of change in satiety scores from baseline $(r=0.350, p=0.023)$. In the men, overconsumption after the preload containing sucrose $(r=-0.934, p=0.020)$ or milk preload $(\mathrm{r}=-0.999, \mathrm{p}<0.001)$ was a function of the magnitude of change in satiety scores from baseline, after the preload containing HFCS this relationship was not present. The milk preload especially suppressed hunger ratings significantly more at each time point compared to the diet preload $(\mathrm{p}<0.05)$. The change in GLP-1 concentrations from baseline after milk consumption, compared to after preloads containing sucrose or HFCS was significantly larger 30 minutes after the drinks 
$(3.6 \pm 3.4$ vs. $2.1 \pm 2.3$ and $2.1 \pm 3.3 \mathrm{pmol} / \mathrm{L}, \mathrm{p}<0.05)$. In men, this difference was observed at each time-point $(\mathrm{p}<0.05)$.

Furthermore, compensation and satiety $(r=0.412, \mathrm{p}<0.05)$ were positively related to change in pleasantness of taste after the preload containing sucrose (the more the pleasantness of taste was suppressed the larger the satiety and compensation), presented in Figure 2.3. Accordingly, plasma glucose concentrations were significantly higher over time after the drinks containing sucrose or HFCS compared to after milk or diet preloads $(\mathrm{p}<0.001)$. Moreover, plasma glucose concentrations were linearly related to the content of glucose of the preloads $(r=0.581, p<0.001)$.

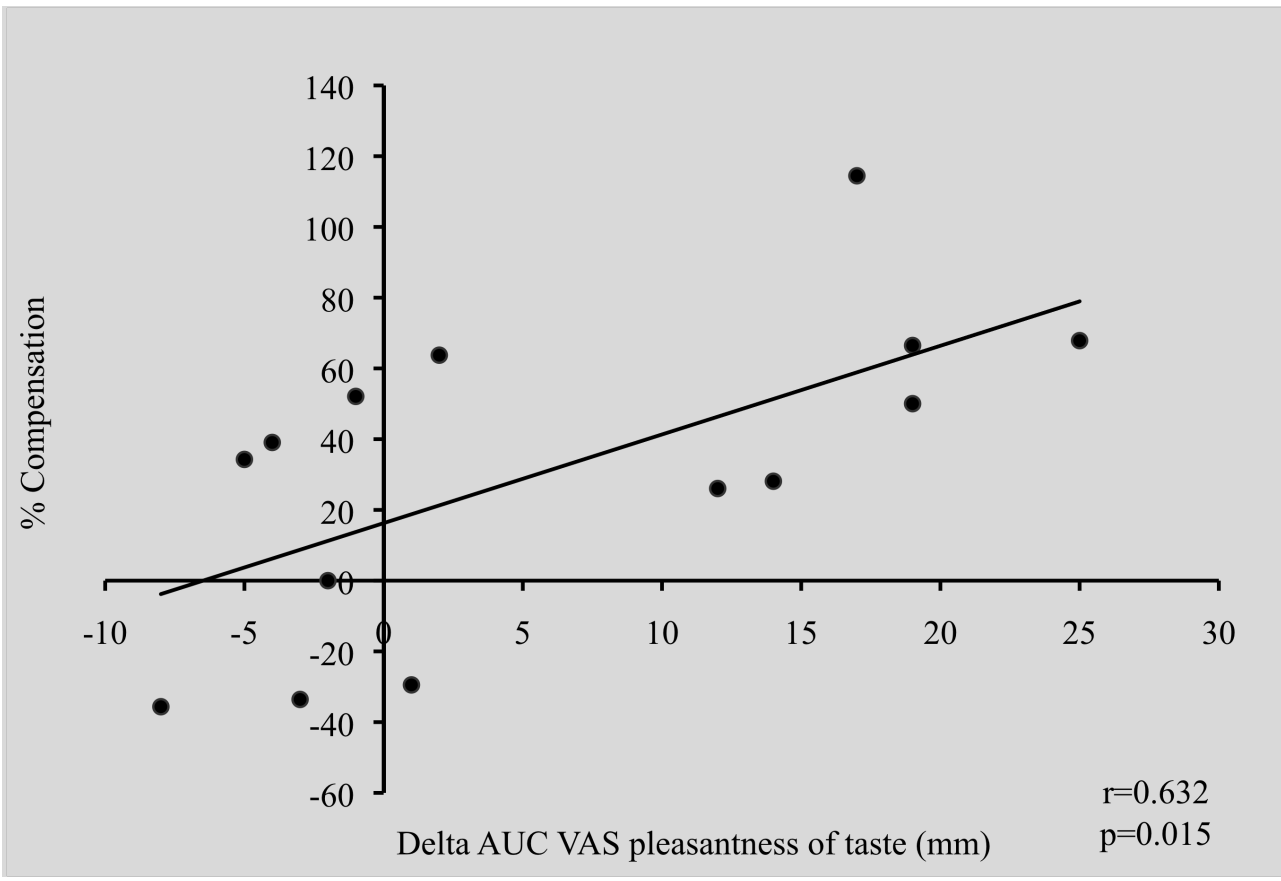

Figure 2.3. Compensation of the sucrose-containing preload of men and women ( $\mathrm{n}=14)$ as a function of AUC (t 0-50 $\mathrm{min})$ of pleasantness of taste $(\mathrm{mm})$. Compensation $=($ EIdiet - EIafter any preload $)$ as a $\%$ of the preload.

\section{DISCUSSION}

Are iso-caloric iso-volumetric sucrose- or HFCS-containing preloads, or milk different in satiety? This question was addressed as follows; (i) are iso-caloric iso-volumetric sucrose- or HFCS-containing preloads, or milk different in satiating effects expressed as mm VAS or GLP-1 or ghrelin responses? The increase in satiety from baseline as AUC did not differ significantly between the sucrose-, HFCS-containing or milk preload. Furthermore, satiety was expressed as compensation or overconsumption during the next meal; this did not show significant differences between the different preloads. From these observations we conclude that there are no differences in satiety or energy balance effects of iso-volumetric sucrose- or HFCS-containing preloads or milk. 
Subsequently the mechanisms underscoring the increases in satiety were revealed. Although differences in satiety were absent mechanisms underlying satiety due to sucrose-, HFCS-containing drinks or milk were different, related to evoking different increases in 'satiety' hormone concentrations.

More in detail, there were no significant differences in energy intakes of the meal 50 minutes after consumption of the $1.5 \mathrm{MJ} 800 \mathrm{~mL}$ drinks containing sucrose or HFCS, neither in total energy consumed. Also energy intake after the iso-energetic isovolumetric milk preload did not differ from energy intake after sucrose or HFCS drinks. Similar to our observations no significant differences were found between effects of 0.9 MJ $500 \mathrm{~mL}$ cola or chocolate-milk consumption with ad libitum intake $30 \mathrm{~min}$ later despite a significantly greater satiety 30min after the chocolate-milk (36), and in subsequent meal compensation 2 hours 15 minutes after preloads of $1.036 \mathrm{MJ}$ $590 \mathrm{~mL}$ cola, orange juice and milk relative to sparkling water (37). As usual, energy intake including the energy containing preloads was higher compared to total energy intake including the diet preload, despite the smaller consumption during the subsequent meal. Thus, subsequent energy intake only partly compensated for the energy delivered by the preloads; i.e. for $45 \%$ for the sucrose- and for $42 \%$ the HFCScontaining preloads, and for $30 \%$ the milk preload, all compared to energy intake after the diet preload. So, consumption of an energy containing preload followed by a meal at 50 minutes lead to overconsumption compared to a diet preload and subsequent meal. Previously, consumption of a $1.26 \mathrm{MJ}$ high fructose-glucose mixture $(80-20 \%)$ was compensated with $12 \%$ of the meal consumed 60 minutes after preload, not differently from an equisweet sucrose drink with $42 \%$ compensation (38). In conclusion, based on these studies a 0.9-1.5 MJ preload containing sucrose or HFCS, or a milk preload does not differ in subsequent energy intake 30 to 135 minutes after preload consumption. Therefore, in general energy balance effects are positive, yet not different between different energy containing drinks.

A gender effect was observed in VAS ratings, energy intake, compensation and overconsumption. Possible explanations for these gender differences are the different responses in hormones GLP-1 and glucose, when preloads of the same sizes are offered. Previous studies support these higher concentrations in women $(39,40)$. Obviously the preloads that were consumed by the men represented a smaller part of energy requirement than the preloads consumed by the women. Moreover, gender differences in water turnover may play a role (41), since it has been suggested that the increased energy intake after drinks may have been derived from physiological mechanisms giving priority to quenching thirst (42). The preloads suppressed thirst equally, however significantly more in women than in men.

(ii) Is the satiety after sucrose- or HFCS-containing, or milk preloads reached by different mechanisms? Consumption of the preloads containing sucrose or HFCS caused similar changes in plasma concentrations of the hormones GLP-1, ghrelin and insulin, and of glucose. Also leptin concentrations did not differ after consumption of either sucrose or HFCS (43). The increase in satiety was underscored by the increase in GLP-1, with the sucrose- or HFCS-containing preloads, but not with the milk preload. Since satiety did not differ between energy containing preloads, it may well be that other satiety hormones such as PYY and CCK, which were not measured, supported the milk-induced satiety. Satiety after the sucrose containing preload was also 
underscored by the increase in insulin, and satiety after the HFCS-containing preload by the decrease in ghrelin. The changes in VAS ratings of the appetite profile were supported by the changes in the concentrations of the hormones GLP-1, ghrelin and insulin, and additionally glucose. Stepwise regression showed that satiety was primarily related to increases of GLP-1 concentrations, and secondarily to insulin concentrations. Thus the sucrose and HFCS have likely triggered GLP-1 release that may have triggered insulin release, with a related increase in satiety.

On the other hand, satiety and compensation after the preload containing sucrose correlated with change in pleasantness of taste. Individuals do not eat solely based on hunger, taste is another reason for eating a specific food, and a decrease in pleasantness of taste is often given as a reason for terminating or reducing food intake. Therefore, the less sweet, refreshing and pleasant milk preload may have contributed to incomplete compensation at the subsequent meal. Furthermore, high glycemic carbohydrates have been associated with a reduced appetite and food intake in the very short term (e.g. one hour), whereas lower glycemic carbohydrates showed a more delayed effect on the perception of satiety (e.g. 2-3 hours) $(44,45)$. We found a linear relationship between content of glucose of the preloads and AUC plasma glucose concentrations. The GI of the monosaccharides glucose, fructose and lactose are 99, 19, and 46, respectively (46). The GI of sucrose is 68 (46) and of HFCS 73 (47) and 68 (48). The glucose concentrations peaked at 30 minutes and dropped below baseline at 60 minutes after the carbohydrate preloads and remained low until the end of the experiment. The same pattern of initial steep increase in plasma glucose and insulin levels followed by a rebound effect, which stimulates hunger and food intake as has been found in several studies $(16,17,32,49-56)$. Thus, a rapid rise in blood glucose and a large insulin response stimulates peripheral glucose uptake to such an extent that the blood glucose concentration falls below the fasting level. Therefore the lower GI of milk, full fat milk: 27, skimmed milk: 32 (46), may have contributed to its satiety effect.

(iii) Is satiety after sucrose-, or HFCS-containing preloads influenced by its biochemical properties? The carbohydrate sucrose is a disaccharide, consisting of one molecule glucose and one molecule fructose, which are not available for absorption until sucrose is hydrolyzed by intestinal brush-border enzymes. HFCS, on the other hand, contains glucose and fructose in their monosaccharide forms, giving their solution a higher osmotic pressure. In soft drinks however, a proportion of the sucrose is hydrolyzed into glucose and fructose by the acidic $\mathrm{pH}$ before the drinks are consumed. Fructose is passively absorbed in the duodenum and jejunum by a GLUT 5 transporter, having a smaller absorption capacity compared to the actively sodiumdependent hexose transporter (SGLP-1), which absorbs glucose in the duodenum (5759). However, there is a more complete and faster transport accompanied by a decrease in malabsorption when fructose is consumed in combination with other carbohydrates $(20,21)$. Both the differences in duration in the intestines and in the osmotic pressure of glucose and fructose could influence satiety differently. Furthermore, glucose triggers CNS-glucose sensors involved in the regulation of food intake (60). Fructose, however, does not cross the blood-brain barrier (61). Fructose could trigger satiety by its oxidation (62), greater thermogenic response (63-65), and by its rapid metabolism in the liver (61). The liver is sensitive to its own metabolism and signals to the brain via 
the vagus nerve to inhibit the central control for meal initiation (61). So, glucose and fructose of sucrose- or HFCS-sweetened drinks contribute to satiety through different biochemical mechanisms.

Summarizing, a 1.5 MJ preload containing sucrose or HFCS, or a milk preload did not affect energy intake 50 minutes later differently. Differences in satiety were absent despite different mechanisms underlying satiety due to sucrose-, HFCS-containing drinks or milk. The sucrose and HFCS triggered GLP-1 release that triggered insulin release, with a related increase in satiety. The different responses in GLP-1, glucose, and thirst when preloads of the same sizes were offered could explain the gender effect that was observed in VAS ratings, energy intake, compensation and overconsumption. Obviously the preloads that were consumed represented a smaller part of energy requirement in men than in women.

Based upon the partial compensation for and overconsumption due to the energy containing preloads, a long-term study to assess the effect on body-weight regulation would be a necessary follow-up. The question remains whether in the long-term this partial overconsumption of about $40-50 \%$ of the meal, amounting to $1 \mathrm{MJ}$, will accumulate. If no other long-term compensating mechanisms would occur, than this would mean an increase in body weight over time of about $1 \mathrm{~kg}$ over 1 month. Here an additional 26-30 MJ accounts for $1 \mathrm{~kg}$ body weight gain (66). To confirm this hypothetical approach or to find long-term compensating mechanisms, a wellcontrolled long-term study would be necessary.

To conclude, despite the differences in biochemical properties of preloads containing sucrose, HFCS, or milk, and differences in mechanisms underlying satiety in relation to GLP-1 release and ghrelin release, there were no differences in satiety, compensation, or overconsumption.

\section{ACKNOWLEDGEMENTS}

We gratefully acknowledge Marijke Prins, Jos Stegen, and Wendy Sluijsmans for their assistance. The study was supported by Suikerstichting Nederland (Baarn, The Netherlands). The drinks were made by United Soft Drinks Ltd, Utrecht. 


\section{REFERENCES}

1. Harnack LJ, Jeffery RW, Boutelle KN. Temporal trends in energy intake in the United States: an ecologic perspective. Am J Clin Nutr 2000;71:1478-84.

2. Krebs-Smith SM. Choose beverages and foods to moderate your intake of sugars: measurement requires quantification. J Nutr 2001;131:527S-535S.

3. Nielsen SJ, Siega-Riz AM, Popkin BM. Trends in energy intake in U.S. between 1977 and 1996: similar shifts seen across age groups. Obes Res 2002;10:370-8.

4. French SA, Lin BH, Guthrie JF. National trends in soft drink consumption among children and adolescents age 6 to 17 years: prevalence, amounts, and sources, 1977/1978 to 1994/1998. J Am Diet Assoc 2003;103:1326-31.

5. Pereira MA. The possible role of sugar-sweetened beverages in obesity etiology: a review of the evidence. Int J Obes (Lond) 2006;30 Suppl 3:S28-36.

6. Flegal KM, Carroll MD, Ogden CL, Johnson CL. Prevalence and trends in obesity among US adults, 1999-2000. Jama 2002;288:1723-7.

7. Ogden CL, Carroll MD, Curtin LR, McDowell MA, Tabak CJ, Flegal KM. Prevalence of overweight and obesity in the United States, 1999-2004. Jama 2006;295:1549-55.

8. Guthrie JF, Morton JF, Schulze MB, et al. Sugar-sweetened beverages, weight gain, and incidence of type 2 diabetes in young and middle-aged women. J Am Diet Assoc 2000;100:4351, quiz 49-50.

9. Nielsen SJ, Popkin BM. Patterns and trends in food portion sizes, 1977-1998. Jama 2003;289:450-3.

10. Nielsen SJ, Popkin BM. Changes in beverage intake between 1977 and 2001. Am J Prev Med 2004;27:205-10.

11. Cordain L, Eaton SB, Sebastian A, et al. Origins and evolution of the Western diet: health implications for the 21st century. Am J Clin Nutr 2005;81:341-54.

12. Bray GA, Nielsen SJ, Popkin BM. Consumption of high-fructose corn syrup in beverages may play a role in the epidemic of obesity. Am J Clin Nutr 2004;79:537-43.

13. Tordoff MG, Alleva AM. Effect of drinking soda sweetened with aspartame or high-fructose corn syrup on food intake and body weight. Am J Clin Nutr 1990;51:963-9.

14. Guss JL, Kissileff HR, Pi-Sunyer FX. Effects of glucose and fructose solutions on food intake and gastric emptying in nonobese women. Am J Physiol 1994;267:R1537-44.

15. Kong MF, Chapman I, Goble E, et al. Effects of oral fructose and glucose on plasma GLP-1 and appetite in normal subjects. Peptides 1999;20:545-51.

16. Vozzo R, Baker B, Wittert GA, et al. Glycemic, hormone, and appetite responses to monosaccharide ingestion in patients with type 2 diabetes. Metabolism 2002;51:949-57.

17. Spitzer L, Rodin J. Effects of fructose and glucose preloads on subsequent food intake. Appetite 1987;8:135-45.

18. Rodin J, Reed D, Jamner L. Metabolic effects of fructose and glucose: implications for food intake. Am J Clin Nutr 1988;47:683-9.

19. Rodin J. Comparative effects of fructose, aspartame, glucose, and water preloads on calorie and macronutrient intake. Am J Clin Nutr 1990;51:428-35.

20. Rumessen JJ, Gudmand-Hoyer E. Absorption capacity of fructose in healthy adults. Comparison with sucrose and its constituent monosaccharides. Gut 1986;27:1161-8.

21. Riby JE, Fujisawa T, Kretchmer N. Fructose absorption. Am J Clin Nutr 1993;58:748S-753S.

22. Mattes RD. Dietary compensation by humans for supplemental energy provided as ethanol or carbohydrate in fluids. Physiol Behav 1996;59:179-87.

23. DiMeglio DP, Mattes RD. Liquid versus solid carbohydrate: effects on food intake and body weight. Int J Obes Relat Metab Disord 2000;24:794-800.

24. Harnack L, Stang J, Story M. Soft drink consumption among US children and adolescents: nutritional consequences. J Am Diet Assoc 1999;99:436-41.

25. Ludwig DS, Peterson KE, Gortmaker SL. Relation between consumption of sugar-sweetened drinks and childhood obesity: a prospective, observational analysis. Lancet 2001;357:505-8. 
26. Mrdjenovic G, Levitsky DA. Nutritional and energetic consequences of sweetened drink consumption in 6- to 13-year-old children. J Pediatr 2003;142:604-10.

27. Berkey CS, Rockett HR, Field AE, Gillman MW, Colditz GA. Sugar-added beverages and adolescent weight change. Obes Res 2004;12:778-88.

28. Raben A, Vasilaras TH, Moller AC, Astrup A. Sucrose compared with artificial sweeteners: different effects on ad libitum food intake and body weight after $10 \mathrm{wk}$ of supplementation in overweight subjects. Am J Clin Nutr 2002;76:721-9.

29. Schulze MB, Manson JE, Ludwig DS, et al. Sugar-sweetened beverages, weight gain, and incidence of type 2 diabetes in young and middle-aged women. Jama 2004;292:927-34.

30. Almiron Roig E, Chen Y, Drewnowski A. Liquid calories and the failure of satiety: how good is the evidence? Obes Rev 2003;4:201-12.

31. Almiron Roig E, Flores SY, Drewnowski A. No difference in satiety or in subsequent energy intakes between a beverage and a solid food. Physiol Behav 2004;82:671-7.

32. Anderson GH, Woodend D. Consumption of sugars and the regulation of short-term satiety and food intake. Am J Clin Nutr 2003;78:843S-849S.

33. Stunkard AJ, Messick S. The three-factor eating questionnaire to measure dietary restraint, disinhibition and hunger. J Psychosom Res 1985;29:71-83.

34. Westerterp Plantenga MS, Rolland V, Wilson SA, Westerterp KR. Satiety related to $24 \mathrm{~h}$ diet induced thermogenesis during high protein/carbohydrate vs high fat diets measured in a respiration chamber. Eur J Clin Nutr 1999;53:495-502.

35. Senn S. Cross-over trials in Statistics in Medicine: the first '25' years. Stat Med 2006;25:343042.

36. Harper A, James A, Flint A, Astrup A. Increased satiety after intake of an isocaloric, isodense chocolate-milk drink compared with cola, but no difference in ad libitum lunch intake. Obes Rev 2005;6(s1):151 (abstr).

37. Almiron Roig E, Drewnowski A. Hunger, thirst, and energy intakes following consumption of caloric beverages. Physiol Behav 2003;79:767-73.

38. Anderson GH, Catherine NL, Woodend DM, Wolever TM. Inverse association between the effect of carbohydrates on blood glucose and subsequent short-term food intake in young men. Am J Clin Nutr 2002;76:1023-30.

39. Vaag AA, Holst JJ, Volund A, Beck-Nielsen HB. Gut incretin hormones in identical twins discordant for non-insulin-dependent diabetes mellitus (NIDDM)--evidence for decreased glucagon-like peptide 1 secretion during oral glucose ingestion in NIDDM twins. Eur $\mathrm{J}$ Endocrinol 1996;135:425-32.

40. Adam TC, Westerterp-Plantenga MS. Nutrient-stimulated GLP-1 release in normal-weight men and women. Horm Metab Res 2005;37:111-7.

41. Westerterp KR, Plasqui G, Goris AH. Water loss as a function of energy intake, physical activity and season. Br J Nutr 2005;93:199-203.

42. Anderson GH. Sugars-containing beverages and postprandial satiety and food intake. Int J Obes 2006;30:S52-S59.

43. Melanson KJ, Zukley L, Lowndes J, Nguyen V, Angelopoulos TJ, Rippe JM. Effects of highfructose corn syrup and sucrose consumption on circulating glucose, insulin, leptin, and ghrelin and on appetite in normal-weight women. Nutrition 2007;23:103-12.

44. Anderson GH, Woodend D. Effect of glycemic carbohydrates on short-term satiety and food intake. Nutr Rev 2003;61:S17-26.

45. McMillan-Price J, Brand-Miller J. Low-glycaemic index diets and body weight regulation. Int J Obes (Lond) 2006;30 Suppl 3:S40-6.

46. Foster-Powell K, Holt SH, Brand-Miller JC. International table of glycemic index and glycemic load values: 2002. Am J Clin Nutr 2002;76:5-56.

47. Hung CT. Effects of high-fructose $(90 \%)$ corn syrup on plasma glucose, insulin, and C-peptide in non-insulin-dependent diabetes mellitus and normal subjects (Abstract). Taiwan Yi Xue Hui Za Zhi 1989;88:883-5.

48. Miller JB, Pang E, Broomhead L. The glycaemic index of foods containing sugars: comparison of foods with naturally-occurring v. added sugars. Br J Nutr 1995;73:613-23. 
49. Crapo PA, Kolterman OG, Olefsky JM. Effects of oral fructose in normal, diabetic, and impaired glucose tolerance subjects. Diabetes Care 1980;3:575-82.

50. Melanson KJ, Westerterp Plantenga MS, Campfield LA, Saris WH. Blood glucose and meal patterns in time-blinded males, after aspartame, carbohydrate, and fat consumption, in relation to sweetness perception. Br J Nutr 1999;82:437-46.

51. Horowitz M, Cunningham KM, Wishart JM, Jones KL, Read NW. The effect of short-term dietary supplementation with glucose on gastric emptying of glucose and fructose and oral glucose tolerance in normal subjects. Diabetologia 1996;39:481-6.

52. Mayer J. Glucostatic mechanism of regulation of food intake. N Engl J Med 1953;249:13-6.

53. Akgun S, Ertel NH. The effects of sucrose, fructose, and high-fructose corn syrup meals on plasma glucose and insulin in non-insulin-dependent diabetic subjects. Diabetes Care $1985 ; 8: 279-83$.

54. Lee BM, Wolever TM. Effect of glucose, sucrose and fructose on plasma glucose and insulin responses in normal humans: comparison with white bread. Eur J Clin Nutr 1998;52:924-8.

55. Woodend DM, Anderson GH. Effect of sucrose and safflower oil preloads on short term appetite and food intake of young men. Appetite 2001;37:185-95.

56. Campfield LA, Smith FJ. Blood glucose dynamics and control of meal initiation: a pattern detection and recognition theory. Physiol Rev 2003;83:25-58.

57. Ravich WJ, Bayless TM, Thomas M. Fructose: incomplete intestinal absorption in humans. Gastroenterology 1983;84:26-9.

58. McIntyre AS, Thompson DG, Burnham WR, Walker E. The effect of beta-adrenoreceptor agonists and antagonists on fructose absorption in man. Aliment Pharmacol Ther 1993;7:267-74.

59. Buchs AE, Sasson S, Joost HG, Cerasi E. Characterization of GLUT5 domains responsible for fructose transport. Endocrinology 1998;139:827-31.

60. Havel PJ. Peripheral signals conveying metabolic information to the brain: short-term and longterm regulation of food intake and energy homeostasis. Exp Biol Med (Maywood) 2001;226:963-77.

61. Friedman MI, Granneman J. Food intake and peripheral factors after recovery from insulininduced hypoglycemia. Am J Physiol 1983;244:R374-82.

62. de Kalbermatten N, Ravussin E, Maeder E, Geser C, Jequier E, Felber JP. Comparison of glucose, fructose, sorbitol, and xylitol utilization in humans during insulin suppression. Metabolism 1980;29:62-7.

63. Tappy L, Randin JP, Felber JP, et al. Comparison of thermogenic effect of fructose and glucose in normal humans. Am J Physiol 1986;250:E718-24.

64. Schwarz JM, Acheson KJ, Tappy L, et al. Thermogenesis and fructose metabolism in humans. Am J Physiol 1992;262:E591-8.

65. Schwarz JM, Schutz Y, Piolino V, Schneider H, Felber JP, Jequier E. Thermogenesis in obese women: effect of fructose vs. glucose added to a meal. Am J Physiol 1992;262:E394-401.

66. Westerterp KR, Donkers JH, Fredrix EW, Boekhoudt P. Energy intake, physical activity and body weight: a simulation model. Br J Nutr 1995;73:337-47. 



\section{PROTEINS AND SATIETY:}

\section{IMPLICATIONS FOR WEIGHT MANAGEMENT}

StiJn Soenen AND MARgriet S WeSterterp-Plantenga

CURR OPIN CLIN NUTR METAB CARE 2008;11(6):747-751 


\section{ABSTRACT}

\section{Purpose of review}

Highlight the satiating background and effects of proteins and their implications for weight management.

\section{Recent findings}

The satiating effect of protein is the key-player in body-weight loss and body-weight maintenance thereafter. Specific high-protein-meals or high-protein-diets induced satiety require a realistic bandwidth of energy intake, protein concentrations, texture, and timing of assessment of effects. Satiety is nutrient specifically supported by elevated amino acid concentrations, responses of anorexigenic hormones or proteininduced energy expenditure. During long-term high-protein diets sustained satiety, energy expenditure, and sparing fat free mass are essential; for effects due to satiety ad libitum energy intake conditions are necessary. Adverse events related to kidney damage may occur with sulphur-containing amino acids; subjects with obesity, metabolic syndrome and diabetes mellitus type 2 may be susceptible groups.

\section{Summary}

Highly controlled medium-term studies overcoming possible differences due to texture, timing and macronutrient exchange, and assessing satiety, energy expenditure and substrate oxidation at the same time, need to be executed with a realistic band-width of different types of proteins in overweight subjects in different energy balances.

\section{Keywords}

amino acids, gut peptides, energy expenditure, adverse effects, timing 


\section{INTRODUCTION}

Obesity is a major health problem with serious co-morbidities $(1,2)$. Conditions for weight maintenance after weight loss are sustained satiety despite negative energy balance, sustained basal energy expenditure despite body-weight loss due to sparing of fat free mass, being the main determinant of basal energy expenditure. Relatively highprotein diets have been shown to act on these metabolic targets (3). This review focuses on satiety, taking type and quantity of protein, administration of protein, timing of effects, characterization of subjects, energy balance, duration of studies, and adverse events into account.

\section{PROTEIN-INDUCED SATIETY BY ACUTE HIGH-PROTEIN MEALS AND MEDIUM-TERM HIGH-PROTEIN DIETS}

A hierarchy has been observed for the satiating efficacies of the macronutrients protein, carbohydrate and fat, with protein being the most satiating and fat the least. This sequence also represents the priority with respect to metabolizing these macronutrients (4). In daily life, as well as in many experiments, mixed proteins are consumed, from meat, fish, dairy products, or plants. A dose dependent satiating effect of mixed protein has been shown, with quite a range of concentrations of protein offered acutely, in a single meal, to subjects who are in energy balance and weight stable $(4,5)$. In addition, persistent protein-induced satiety has been shown when a mixed high-protein diet was given for 24 hours up to several days (6-8). This section discusses acute, high-protein meal- or drink-induced satiety, and medium-term, high-protein diet-induced satiety. Mechanisms contributing to protein-induced satiety are considered.

\section{Acute high-protein meal-induced satiety}

Protein-induced satiety has been shown acutely, with single meals, with contents of $25 \%$ to $81 \%$ of energy from mixed protein or specific proteins, followed by subsequent energy intake reduction (4). Given the range of 'normal' protein intake of on average $10-15 \%$ of energy, meals with on average $20 \%$ to $30 \%$ of energy from protein are representative for high-protein diets, when consumed in energy balance (3). Using these protein levels, Smeets et al. showed, in healthy, normal weight subjects (BMI $23.8 \pm 2.8 \mathrm{~kg} / \mathrm{m}^{2}$; fat percentage $25.6 \pm 8.8 \%$ ) that after a high-protein lunch satiety and energy expenditure were significantly higher than after a normal-protein lunch, without differences in ghrelin, and PYY (peptide tyrosin-tyrosin) responses (5). The glucagonlike peptide 1 (GLP-1) response was smaller following the high-protein lunch, due to the high-carbohydrate induced GLP-1 response during the normal-protein lunch, showing clearly that a GLP-1 response is primarily nutrient related, and only secondarily satiety related (5). Optimal use of satiating power of a high-protein meal was shown when timing of the meal interval synchronizes with timing of the amino acid profiles (9), ghrelin concentrations (10), or VAS (visual analogue scale) satiety ratings (10). In these studies, 'feeling' of satiety, hunger fullness or desire to eat are generally detected by the subject and represented using $100 \mathrm{~mm}$ visual analogue rating scales (VAS), asking the appetite profile related questions anchored with the extreme negative and positive answers. A point on the scale then gives the value of hunger, satiety, etc. Veldhorst et al. timed test meals beforehand, by running the experiments, 
in healthy normal weight subjects (BMI $23.9 \pm 0.3 \mathrm{~kg} / \mathrm{m}^{2}$ ), twice: first determining the moment in time when differences in satiety or ghrelin concentrations were still significantly present, then offering the test meal at that moment in the next experiment $(4,10,11)$. Outcomes appeared to differ due to type or quantity of protein intake, or both. Higher satiating effects due to higher concentrations of casein (11) or soy (4) (25 vs. $10 \%$ of energy) were related to kinetics of amino acid profiles $(4,11)$.

With whey as a single protein in a subject specifically standardized custard breakfast, energy intake was decreased by $13 \%$ three hours after a breakfast with whey containing glyco-macro-peptide (GMP) compared to energy intake after a breakfast with whey without GMP, irrespective of the whey-protein content being 10 or $25 \%$ of energy in the custard breakfast, co-inciding with increased concentrations of certain amino acids, e.g. serine, threonine, alanine, and isoleucine (10). Similarly, the hypothesis of tryptophan (Trp), as a precursor for the anorexigenic neurotransmitter serotonin, depending on the plasma ratio of Trp to large neutral amino acids contributing to satiety was tested. Nieuwenhuizen et al. observed stronger hunger suppression 4 hours after a breakfast with alpha-lactalbumin compared to gelatin with or without added tryptophan as the only protein source (12) in healthy normal weight subjects (BMI $23.8 \pm 0.4 \mathrm{~kg} / \mathrm{m}^{2}$ ). However, total plasma amino acid responses, plasma tryptophan concentrations, plasma tryptophan/LNAA (large neutral amino acids) ratios, as well as GLP-1 and ghrelin concentrations were not related to hunger, and energy intake during subsequent lunch was similar for all 3 diets. They conclude that plasma tryptophan/LNAA ratios did not contribute to satiety, as has been hypothesized before (12). Testing the same hypothesis Koren et al. concluded from a study in healthy overweight subjects (BMI $27 \pm 2.3 \mathrm{~kg} / \mathrm{m}^{2}$ ) that an increase in either carbohydrate or protein intake increases satiety and leads to significant weight loss, independent of an increase in plasma concentration of Trp or the Trp/LNAA ratio (13).

Comparing effects of seven different proteins in two different concentrations, on energy intake during the subsequent meal, Veldhorst et al., observed in the same healthy normal weight subjects as mentioned above, a more satiating effect from incomplete protein, i.e. those that lack some essential amino acids vs. complete proteins, those that have the essential amino acids on board. At the level of 10 energy percentage and of 25 energy percentage from one type of protein consumed with a breakfast custard, energy intake at lunch was about $20 \%$ less after an alpha-lactalbumin or gelatin with or without added tryptophan breakfast, compared with after a casein, soy, or whey breakfast; differences in energy intakes of about $20 \%$ where a function of differences in satiety ratings, that showed a difference of about $40 \%$ (14). Assessing different proteins and hydrolysates, Diepvens et al. showed in healthy overweight subjects (BMI $27.6 \pm 1.7 \mathrm{~kg} / \mathrm{m}^{2}$; fat percentage $32.6 \pm 7.9 \%$ ) indications of lower hunger and desire to eat or higher satiety after consumption of pea protein hydrolysate or whey protein compared to milk protein or whey protein + pea protein hydrolysate (15). Effects on relevant hormones were primarily nutrient related. Cholecystokinin (CCK) and GLP-1 concentrations were relatively more increased by milk protein while PYY concentrations were relatively more elevated and ghrelin concentrations more reduced by whey protein + pea protein hydrolysate (15). No effect on energy intake was seen (15). A similar effect of protein consumption on PYY concentration changes was 
shown by Batterham et al., observing significantly higher plasma PYY responses to a high-protein meal in both lean and obese subjects (16).

With respect to different fractions of protein, such as alpha-lactalbumin or betalactalbumin, Pichon et al. observed that food intake and body weight gain were significantly lower in rats fed the diet containing beta-lactalbumin, which was unrelated to palatability (17).

When different proteins or amino acids were consumed at very high levels, satiety was very high, and no differences in satiating effects were observed anymore. For instance Bowen et al. did not find different effects between casein and whey protein, with high-protein meals inducing larger satiating effect than high-carbohydrate meals $(18,19)$, in healthy normal weight subjects. Furthermore, they noted different appetite regulatory hormone responses after whey, soy, or gluten preload despite similar reductions in ad libitum energy intake (19). Also Burton-Freeman et al. studied food intake in healthy normal weight to overweight (BMI $25 \pm 1.5 \mathrm{~kg} / \mathrm{m}^{2}$ ) and did not find a difference at the test meal, between the conditions with preloads consisting of whey with or without GMP, while CCK release coincided with magnitude of satiety ratings (20).

Effects of protein containing drinks vs. control appear when sufficient protein and energy is present in the drinks. Bertenshaw et al. compared in normal weight men (BMI $22.6 \pm 0.4 \mathrm{~kg} / \mathrm{m}^{2}$ ) iso-energetic dairy fruit drink preloads $(300 \mathrm{~mL} 1.25 \mathrm{MJ}$ ) differing in macronutrient composition and observed that significantly less energy was consumed at lunch $120 \mathrm{~min}$ after the protein (3.2 MJ) compared to the control (3.5 MJ) and $\mathrm{CHO}$ preloads $(3.6 \mathrm{MJ})$, without showing complete energy intake compensation (21). Harper et al. compared in healthy subjects (BMI $22 \pm 2 \mathrm{~kg} / \mathrm{m}^{2}$ ) effects of a sugarsweetened beverage (cola) and a chocolate milk drink $(0.9 \mathrm{MJ}, 500 \mathrm{~mL})$, and observed satiety and fullness being significantly greater $30 \mathrm{~min}$ after chocolate milk than after cola, while no significant difference in energy intake occurred during lunch (3.2 MJ after chocolate milk vs. 3.3 MJ after cola) (22). Soenen et al. showed in healthy normal weight subjects (BMI $22.1 \pm 1.9 \mathrm{~kg} / \mathrm{m}^{2}$ ) no different effects from a comparison between appetite, energy intake or energy intake compensation $50 \mathrm{~min}$ after $800 \mathrm{~mL}, 1.5 \mathrm{MJ}$ milk or carbohydrate drinks, in 40 young healthy normal weight men and women (23). A study in normal weight and obese boys showed that following glucose and wheyprotein drinks $(250 \mathrm{~mL} 3.5 \mathrm{MJ})$ subsequent food intake 60 min later was suppressed by whey protein $(2.7 \mathrm{MJ})$ more than by glucose (3.1 MJ), or control (3.6 MJ) (24). Taken together, there is a band-width in protein amount and concentrations where relatively more protein is more satiating and promotes less energy intake, supported by relatively elevated amino acid concentrations, anorexigenic hormones or energy expenditure, feeding back on the central nervous system. Mellinkoff (25) suggested already in 1956 that an elevated concentration of blood or plasma amino acids, which cannot be channeled into protein synthesis, serves as a satiety signal for a food intake regulating mechanism and thereby result in depressed food intake. With respect to central regulation, Faipoux et al. (26) showed in rats, that protein-induced satiety was related to vagal feedback to the nucleus tractus solitarius in the brainstem, where it represents satiety at almost a reflex level, and the hypothalamus, where it suppresses feelings of hunger (26). 


\section{High-protein-diet-induced satiety}

When high protein menus are offered at each meal, lasting for one to several days, one gets into the condition of a high-protein diet, when metabolic reactions have been established $(3,4,8,27)$. In several high-protein diet studies in normal weight healthy subjects, a continuously higher satiety has been shown throughout the day after the high- compared with the normal-protein diet, for instance in the energy balance controlled environment of a respiration chamber $(3,4,8,27)$. Here, a normal protein diet given in energy balance contains $10-15 \%$ of energy from protein (3), and a highprotein diet in energy balance contains $20-30 \%$ of energy from protein (3). A highprotein-diet in the presence of carbohydrate stimulated GLP-1 release $(8,27)$, which triggers insulin release. More importantly, high protein-diet-induced satiety was primarily related to elevated energy expenditure $(3,4,8,27)$, implying increased oxygen consumption and an increase in body temperature both leading to feeling deprived of oxygen and thus promote satiety $(3,4)$. Energy expenditure is different due to different protein sources, and mediated by the high ATP costs of postprandial protein synthesis while digestion rate also plays a role (3). Following the stoichiometry of amino acid catabolism and urea synthesis, the calculated energy expenditure to produce ATP ranges from $99 \mathrm{~kJ} / \mathrm{ATP}$ for glutamate to $153 \mathrm{~kJ} / \mathrm{ATP}$ for cysteine. For glucose, this value is $91 \mathrm{~kJ} / \mathrm{ATP}$ (3). Moreover, during high-protein diets substrate oxidation changes, in that less protein is oxidized than consumed resulting in a positive protein balance, and more fat is oxidized than consumed, resulting in a negative fat balance; moreover, energy expenditure is continuously elevated $(3,4,8,27)$.

These highly-controlled medium-term studies overcome possible differences due to solid, semi-solid or liquid food, timing and macronutrient exchange, and imply the possibility to assess satiety, energy expenditure and substrate oxidation at the same time. More of this type of studies needs to be executed with different types of proteins, in overweight subjects in neutral, positive and negative energy balances.

\section{IMPLICATIONS OF PROTEIN INDUCED SATIETY IN WEIGHT MANAGEMENT}

Relatively larger body-weight loss on a sustained relatively high-protein diet relates to high-protein-diet induced satiety, energy expenditure, and sparing fat free mass $(3,6,7)$. Since under iso-energetic conditions no statistically significant difference between body-weight loss on a high-protein vs. high-carbohydrate diet appeared although body composition did improve, ad libitum energy intake conditions are necessary in order to lose more body weight [3,6,7]. Relatively high-protein diets consist of at least $25-30 \%$ of energy from protein implying a sustained normal protein intake in grams, while energy intake is decreased. Such diets are relatively high in protein, expressed as percentage energy from protein, but in absolute terms ( $g$ of protein) they only contain a sufficient absolute amount ( $\mathrm{g}$ ) of protein but less energy in total; the absolute amount of protein is the same in a relatively normal protein diet (10-15\% of energy from protein) in neutral energy balance (energy intake matches energy requirement set by energy expenditure), as in a relatively high-protein diet (20-30\% of energy from protein) in negative energy balance (energy intake is lower than energy requirement set by energy expenditure), when subjects consume for instance only half of their energy 
requirements in order to lose body-weight. Weigle et al. showed that at first a highprotein diet has a greater satiating effect than an iso-energetic normal protein diet when fed for two weeks in energy balance of $\sim 10 \mathrm{MJ} / \mathrm{d}$, while thereafter a reduction of energy intake of $\sim 2 \mathrm{MJ} / \mathrm{d}$ occurred when the high-protein diet was offered ad libitum, thereby sustaining the previous level of satiety (28). Despite the reduced energy intake, the diet being relatively high in protein (30\% energy), yielded an absolute amount of protein that was high enough $(\sim 144 \mathrm{~g})$ to sustain satiety at the original satiety level determined by the subject, while energy intake was reduced (28).

Relatively high-protein diets consumed ad libitum also promote weight maintenance. For example, overweight to moderately obese men and women who had lost $7.5 \pm 2.0 \%$ body weight over 4 weeks and consumed $18 \%$ of energy intake as protein, regained less weight ( $1 \mathrm{~kg}$ ) after 3 months, compared to those consuming $15 \%$ of energy as protein (weight regain $2 \mathrm{~kg}$ ) (6), or of $0.8 \mathrm{~kg}$ vs. $3.0 \mathrm{~kg}$ after six months (7), or $1.0 \mathrm{~kg}$ vs. $3.9 \mathrm{~kg}$ after 1 year (7). Here evidence shows that a relatively highprotein intake sustains weight maintenance by favoring regain of fat free mass at the cost of fat mass at a similar physical activity level thereby sustaining energy expenditure, reducing the energy efficiency with respect to the body mass regained, and increasing satiety $(3,6,7)$.

Taken together, relative high-protein low-energy diets, offered ad libitum, whereby the absolute amount of protein as consumed before dieting is sustained, promote weight loss as well as weight maintenance. It remains to be assessed whether and how different types of protein contribute differently to this phenomenon.

\section{ADVERSE EVENTS}

Long-term consumption of high-protein diets in the absolute sense, i.e. in grams, may have adverse effects on the kidney, e.g. on blood pressure. Amino acids involved in gluconeogenesis and/or ureagenesis have a blood pressure lowering effect, whereas acidifying amino acids have a blood pressure raising effect (29-32). Subjects with subclinical renal injury, such as elderly subjects, subjects with low renal functional mass such as renal-transplant recipients, and subjects with obesity-related conditions, such as metabolic syndrome and diabetes mellitus type 2 are more susceptible to the blood pressure raising effects than others (29-32). Especially sulphur-containing amino acids cause a blood pressure raising effect, by maintaining acid-base homeostasis through excretion of the excess acid load by the kidneys $(29,30)$. When kidneys compensate by increased excretion of ammonia, through stimulated ammoniagenesis, with glutamine as substrate, an effect on blood pressure occurs leading to loss of nephron mass (2932). The established synergy between obesity and low nephron number on induction of high blood pressure identifies subjects with obesity, metabolic syndrome and diabetes mellitus type 2 as particularly susceptible groups (20,32).

\section{CONCLUSION}

Assessing possible differences between satiating efficacy of high specific proteinmeals or protein-diets, requires a realistic bandwidth of energy intake and protein concentrations of $20 \%$ to $30 \%$ of energy from protein in energy balance. Timing of assessment of effects is essential, therefore synchronization with amino acid profiles, 
VAS ratings or ghrelin concentrations is recommended. Assessment of mechanisms encompasses assessment of concentration changes of (an)orexigenic hormones, aminoacid profiles, and energy expenditure. Differences in short-term satiety mainly coincide with increased amino acid concentrations; concentrations of 'anorexigenic' hormones underscore nutrient-induced satiety, yet are not directly and mathematically related to satiety. Medium-term elevated protein induced satiety is related to elevated energy expenditure. Increased energy expenditure itself is one of the high-protein-diet targets, as well as a positive protein and negative fat balance. Highly-controlled medium-term studies overcome possible differences due to solid, semi-solid or liquid food, timing and macronutrient exchange, and imply the possibility to assess satiety, energy expenditure and substrate oxidation at the same time. This still needs to be executed with different types of proteins in overweight subjects in different energy balances. During high-protein weight-loss or weight-maintenance diets sustained satiety, energy expenditure, and sparing fat free mass are essential. Allowing satiety to play its crucial role, ad libitum energy intake conditions are necessary. Adverse events may occur with sulphur-containing amino acids increasing blood pressure. Subjects with obesity, metabolic syndrome and diabetes mellitus type 2 are particularly susceptible groups. 


\section{REFERENCES}

1. Seidell JC. Obesity in Europe. Obes Res, 1995; 3 Suppl 2:89s-93s.

2. Pi-Sunyer FX. Medical hazards of obesity. Ann Intern Med, 1993;119(7 Pt 2): 655-60.

3. Westerterp-Plantenga MS, Luscombe-Marsh N, Lejeune MPGM et al. Dietary protein, metabolism, and body-weight regulation: dose-response effects. Int J Obes. 2006;30:S16-S23.

4. Veldhorst M, Smeets A, Soenen S et al. Protein-induced satiety: Effects and mechanisms of different proteins.Physiol Behav. 2008;94(2):300-7.

5. Smeets AJ, Soenen S, Luscombe-Marsh ND et al. Energy expenditure, satiety, and plasma ghrelin, glucagon-like peptide 1, and peptide tyrosine-tyrosine concentrations following a single high-protein lunch. J Nutr. 2008;138(4):698-702.

6. Westerterp-Plantenga MS, Lejeune MP, Nijs I et al. High protein intake sustains weight maintenance after body-weight loss in humans. Int J Obes Relat Metab Disord, 2004;28:57-64.

7. Lejeune MP. Kovacs EM, Westerterp-Plantenga MS. Additional protein intake limits weight regain after weight loss in humans. Br J Nutr, 2005;93(2):281-9.

8. Lejeune MP, Westerterp KR, Adam TC et al. Ghrelin and glucagon-like peptide 1 concentrations, 24-h satiety, and energy and substrate metabolism during a high-protein diet and measured in a respiration chamber. Am J Clin Nutr, 2006;83(1):89-94.

9. Luhovyy BL, Akhavan T, Anderson GH. Whey proteins in the regulation of food intake and satiety. J Am Coll Nutr. 2007;26(6):704S-12S.

10. Veldhorst MAB, Nieuwenhuizen A, Hochstenbach-Waelen A et al. Effects of high and normal whey with or without GMP- protein breakfasts on amino acid, satiety, 'satiety' hormone responses and energy intake. Appetite, 2007. 49(1): p. 336.

11. Veldhorst MAB, Nieuwenhuizen A, Hochstenbach-Waelen A et al. Comparison of the effects of high and normal casein-breakfasts on satiety, 'satiety' hormones, plasma amino acids and subsequent energy intake. British Journal of Nutrition, 2008, in press

12. Nieuwenhuizen AG, Hochstenbach-Waelen A, Veldhorst M A B et al. Effects of alphalactalbumin and gelatin with or without tryptophan protein breakfasts on hunger, 'satiety' hormones, and protein kinetics. Int J Obes. 2008;32:30.

13. Koren MS, Purnell JQ, Breen PA et al. Changes in plasma amino Acid levels do not predict satiety and weight loss on diets with modified macronutrient composition. Ann Nutr Metab. 2007;51(2):182-7.

14. Veldhorst MAB, Nieuwenhuizen A, Hochstenbach-Waelen A et al. Effects of casein, soy, whey with or without GMP, alphalactalbumin, or gelatin with or withour tryptophan-protein breakfasts on energy intake. Int J Obes. 2008;32:142.

15. Diepvens K, Haberer D, Westerterp-Plantenga MS. Different proteins and biopeptides differently affect satiety and anorexigenic/orexigenic hormones in healthy humans. Int J Obes 2008;32:1018.

16. Batterham RL, Heffron $\mathrm{H}$, Kapoor $\mathrm{S}$ et al. Critical role for peptide $\mathrm{YY}$ in protein-mediated satiation and body-weight regulation. Cell Metab. 2006;4:223-33.

17. Pichon L, Potier M, Tome D et al., High-protein diets containing different milk protein fractions differently influence food intake and adiposity in rat. Br J Nutr. 2008;99(4):739-48

18. Bowen J, Noakes M, Clifton PM. Energy intake, ghrelin, and cholecystokinin after different carbohydrate and protein preloads in overweight men. J Clin Endocrinol Metab, 2006;91(4):1477-83.

19. Bowen J, Noakes M, Clifton PM. Appetite regulatory hormone responses to various dietary proteins differ by body mass index status despite similar reductions in ad libitum energy intake. J Clin Endocrinol Metab. 2006;91(8): 2913-9.

20. Burton Freeman BM. Glycomacropeptide (GMP) is not critical to whey-induced satiety, but may have a unique role in energy intake regulation through cholecystokinin (CCK). Physiol Behav 2008;93:379-87.

21. Bertenshaw EJ, Lluch A, Yeomans MR. Satiating effects of protein but not carbohydrate consumed in a between meal beverage context. Physiol Behav 2008, 93, 427-36. 
22. Harper A, James A, Flint A et al. Increased satiety after intake of a chocolate milk drink compared with a carbonated beverage, but no difference in subsequent ad libitum lunch intake. Br J Nutr 2007, 97: 579-83.

23. Soenen S, Westerterp-Plantenga MS. No differences in satiety or energy intake after highfructosee corn syrup, sucrose, or milk preloads. Am J Clin Nutr 2007, 86:1586-94.

24. Bellissimo N, Desantadina MV, Pencharz PB et al. A comparison of short-term appetite and energy intakes in normal weight and obese boys following glucose and whey-protein drinks. Int J Obes (Lond). 2008:32(2):362-71.

25. Mellinkoff SM. Relationship between serum amino acid concentration and fluctuations in appetite. J Appl Physiol, 1956. 8(5): p. 535-8.16.

26. Faipoux R, Tomé D, Gougis S et al. Proteins activate satiety-related neuronal pathways in the brainstem and hypothalamus of rats. J Nutr. 2008;138(6):1172-8.

27. Lejeune MP, Luscombe-Marsh ND, Westerterp-Plantenga MS. 24h energy metabolism, satiety, and hormone concentrations during a high-protein diet measured in a respiration chamber in lean men. Unpublished data.

28. Weigle DS, Breen PA, Matthys CC et al. A high-protein diet induces sustained reductions in appetite, ad libitum caloric intake, and body weight despite compensatory changes in diurnal plasma leptin and ghrelin concentrations. Am J Clin Nutr, 2005;82(1): 41-8.

29. Frassetto LA, Morris RCJr, Sebastian A. A practical approach to the balance between acid production and renal acid excretion in humans. J Nephrol 2006;19 Suppl 9:S33-S40.

30. Hoy WE, Hughson MD, Bertram JF et al. Nephron number, hypertension, renal disease, and renal failure. J Am Soc Nephrol 2005;16:2557-64.

31. Praga, M. Synergy of low nephron number and obesity: a new focus on hyperfiltration nephropathy. Nephrol Dial Transplant 2005;20:2594-7.

32. Bagby SP. Maternal nutrition, low nephron number, and hypertension in later life: pathways of nutritional programming. J Nutr 2007;137:1066-72. 



\section{SUSTAINED INTAKE OF REQUIRED PROTEIN OPTIMAL FOR WEIGHT LOSS, SUPRA-SUSTAINED PROTEIN INTAKE OPTIMAL FOR WEIGHT MAINTENANCE}

StiJn Soenen, ANANda HochStenbach-W Aelen AND MARgRiet S WesterterP-Plantenga 


\section{ABSTRACT}

\section{Background}

High-protein diets have gained considerable interest to reach successful body-weight loss and weight maintenance thereafter.

\section{Objective}

Our objective was to examine if a sustained (SP) compared to a supra-sustained (SSP) milk-protein intake results into a difference in body weight (BM) and body composition over a 6-month intervention.

\section{Design}

Body composition of 43 subjects (BMI $31 \pm 5 \mathrm{~kg} / \mathrm{m}^{2}$ and fat percentage $39 \pm 8 \%$ ), resting energy expenditure, satiety and blood- and urine-parameters were assessed before and after energy intakes of $100 \%, 33 \%$ and $67 \%$ for 1,1 and 2 months respectively (phases 1,2 and 3), with protein intake from meal replacements and 2 months of $67 \%$ energy intake including ad libitum protein intake additional to the meal replacements (phase 4). The SP- and SSP-diets consisted of $10 / 50 / 40$ and $20 / 50 / 30 \mathrm{E} \%$ protein/carbohydrate/fat at baseline and resulted in $0.8 \pm 0.3 \mathrm{~g} / \mathrm{kgBM}$ and a significant higher protein intake (24-hour nitrogen) of $1.2 \pm 0.3 \mathrm{~g} / \mathrm{kgBM}$, respectively $(\mathrm{p}<0.05)$.

\section{Results}

Body weight and fat percentage decreased in both groups after 6 months (SP $-7 \pm 5 \mathrm{~kg}$ and $-5 \pm 3 \%$; SSP $-6 \pm 3 \mathrm{~kg}$ and $-5 \pm 3 \%, \mathrm{p}<0.001$ ). Fat free mass did not decrease in the SSP-group but slightly decreased in the SP-group after 6-months (SP vs. SSP; $-0.8 \pm 1.4 \mathrm{~kg}$ vs. $0.1 \pm 1.0 \mathrm{~kg}$ ). Fat free mass decreased in both groups less compared to its predicted decrease. Resting energy expenditure as function fat free mass did not decrease in the SSP-diet and decreased only slightly in the SP-diet after 4 months.

\section{Conclusion}

A sustained-protein intake results in similar decrease in body weight and fat percentage compared with a supra-sustained protein intake, while fat free mass is extra preserved in the presence of the extra high protein.

\section{Keywords}

protein leverage, fat free mass, resting energy expenditure, weight loss 


\section{INTRODUCTION}

As overweight and obesity are associated with increased risk of several diseases, it is relevant to reduce the excess of body weight and fat percentage and maintain the lowered body weight during lifetime. Obesity results from a positive energy balance over a longer period of time, occurring when energy intake exceeds energy expenditure. This slow development of increase in body weight and fat percentage is mostly combated with strict restriction of energy intake over a relatively short period of time, i.e. 0 to 6 months. Remarkably, obese subjects that intend to lose weight have several of those strict energy-restriction periods of time in their lifetime. Indeed, it is difficult to maintain the reduced body weight, because resting energy expenditure decreases more than predicted from the amount of body-weight loss during energy restriction. A restriction of 26-30 MJ results in reduction of $1 \mathrm{~kg}$ body mass, or about $0.67 \mathrm{~kg}$ fat mass plus $0.33 \mathrm{~kg}$ fat free mass (1). As fat free mass is the main determinant of resting metabolic rate (2) as well as 24-hour energy expenditure (3), preservation of fat free mass is crucial to prevent a positive energy balance after bodyweight loss. In this respect, elevated protein diets were more successful compared to control diets in reduction of body weight and sparing of fat free mass during energy restriction, and maintenance of body weight thereafter (4-7). These so-called 'highprotein' diets with energy percentages of 20 to $30 \%$ of protein during energy restriction of about $50 \%$, actually sustain the absolute amount of required protein $(0.8 \mathrm{~g} / \mathrm{kg}$ body mass) during energy balance (energy percentages of 10 to $15 \%$ of protein during weight-stable conditions). Furthermore, the protein leverage hypothesis (8) provides a mechanism for why sustaining protein intake is important in diet regimes to promote weight loss. Individuals do not overconsume energy when the diet has an increased protein to carbohydrate and fat ratio, or a sustained protein intake during reduced energy intake. In contrast, individuals overeat a diet containing a lower ratio of protein to carbohydrate and fat until the daily intake target amount of protein is ingested, and not the target of total energy intake where there would still be a deficit of protein intake (8). The question remains if optimal reduction of body weight and maintenance of body weight thereafter is reached by a sustained-protein diet, with sustained protein intake of requirements during energy balance, or a supra-sustained-protein diet, were protein intake exceeds the levels of protein requirement. Therefore, the aim of this study was to compare possible differences in reduction of body weight and changes in body composition as a result of 2 diets contrasting in protein intake in 4 different phases of energy intake during 6 months.

\section{METHODS}

The study was conducted following a randomized parallel design including 2 energyrestriction diets differing in protein content, namely sustained-protein (SP) and suprasustained-protein (SSP). The Medical Ethics committee of Maastricht University Medical Centre approved the study. All participants gave written informed consent.

\section{Participants}

Participants were recruited with advertisements in local newspapers. The study protocol was explained orally and a paper version was handed-out. Inclusion criteria 
were age $18-80$ years and BMI $>25 \mathrm{~kg} / \mathrm{m}^{2}$. Exclusion criteria were smoking, the use of medication except the use of contraceptives for women, underlying malignity, more than $10 \%$ reduction of body weight during the last 6 months, furthermore women who were pregnant or breastfeeding were excluded. From the 59 participants who started, 16 dropped-out: 10 in the SP- and 6 in the SSP-group; or 8 (SP 5 and SSP 3) during the strict energy-restriction phase, 6 (SP 3 and SSP 3) more during the mild energyrestriction phase, and 2 (SP 2 and SSP 0) during the ad libitum phase. Participants stopped due to several reasons, such as personal reasons and inability to fulfill the schedule with visits to the clinic.

Table 4.1. Dietary composition

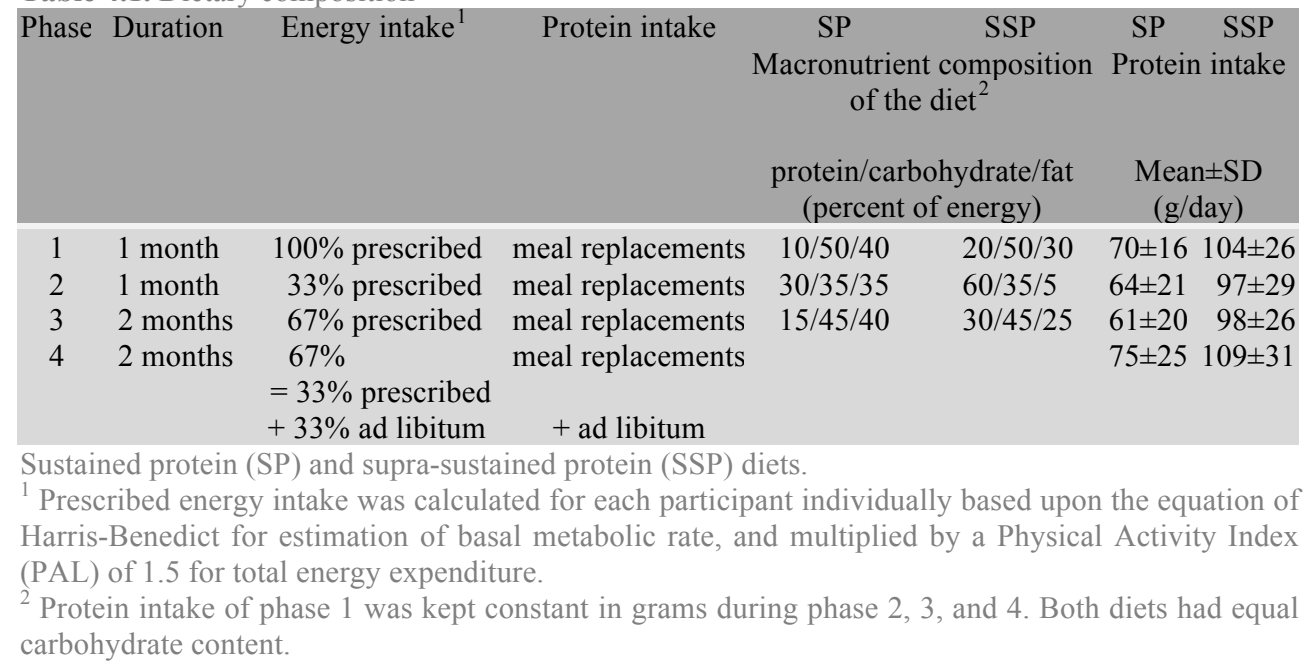

\section{Dietary intervention}

The study had a duration of 6 months and consisted of 4 phases (Table 4.1). The first phase was a run-in phase of 1 month prescribed energy intake at the level of $100 \%$ of subject specific energy requirements, and a protein source supplied from meal replacements. The second phase was 1 month of prescribed energy intake of $33 \%$ with the protein source supplied from meal replacements. The third phase was 2 months of prescribed energy intake of $67 \%$ with the protein source supplied from meal replacements. The forth phase were 2 months to examine the impact of weight development after these energy-restriction phases, were participants consumed food ad libitum in combination with prescribed intake to reach energy intake of about $67 \%$ of energy.

Prescribed energy intake was calculated for each participant individually based upon the equation of Harris-Benedict (9) for estimation of basal metabolic rate, and multiplied by a Physical Activity Index (PAL) of 1.5 for total energy expenditure. Baseline protein intake of the first phase was kept constant in grams during the entire study according to the protein leverage hypothesis (8) to ensure sufficient protein availability for the preservation of fat free mass. Furthermore, both diets had equal carbohydrate content. Therefore, the macronutrient composition in percentage of energy changes in the different phases during the study, but the absolute protein 
content in grams is stable throughout the duration of the study. Diets were a combination of customized meal replacements to reach protein content of the diet, combined with prescribed food items to match macronutrient content of the diet. The meal replacements contained per $100 \mathrm{~g}, 61 \mathrm{~g}$ milk protein, $27 \mathrm{~g}$ carbohydrate (lactose) and $1 \mathrm{~g}$ fat. Subjects were instructed to consume daily at least $200 \mathrm{~g}$ of fruit and $300 \mathrm{~g}$ of vegetables, and to maintain their customary level of physical activity during the entire duration of the study.

\section{Measurements}

Participants were familiarized with the equipment and the procedures before the start of all measurements. Anthropometry, body composition and urinary nitrogen were measured at baseline and after phases 1, 2, 3 and 4. Energy expenditure and blood parameters were measured at baseline and after phases 1,2 and 3.

Height was measured at screening to the nearest $0.1 \mathrm{~cm}$ (Seca-stadiometer, model 220, Hamburg, Germany). Body weight (BM) was measured with subjects in underwear after an overnight fast using a calibrated scale of the Bod $\operatorname{Pod}^{\circledR}$. Body mass index (BMI) was calculated by dividing body weight by height squared $\left(\mathrm{kg} / \mathrm{m}^{2}\right)$. Waist circumference was measured at the site of smallest circumference between rib cage and iliac crest and hip circumference was measured at the site of largest circumference between waist and thighs. Systolic and diastolic blood pressures were recorded using an automatic blood pressure monitor with subjects in sitting position (OMRON M6, Hoofddorp, The Netherlands).

Body composition was calculated from body volume of the $\operatorname{Bod~Pod~}^{\circledR}$ (Life measurement, Concord, CA, USA) (10) and total body water of the deuterium-dilution technique (11) using Siri's three-compartment model (12). The dilution of the deuterium isotope $\left({ }^{2} \mathrm{H}_{2} \mathrm{O}\right)$ is a measure for total body water. Fat free mass was calculated by dividing total body water by the hydrating factor 0.73 . Participants wore tightly fitting bathing suits and a swim cap during the volume-measurements of the Bod Pod $^{\circledR}$, and had not engaged in exercise at least 1 hour prior to the test.

Resting energy expenditure was measured with subjects lying supine by means of an open circuit ventilated hood system. Gas analysis was performed by a paramagnetic oxygen analyzer (Omnical type 1155B, Crowborough Sussex, UK) and an infrared carbon dioxide analyzer (Omnical type 1520/1507). Resting energy expenditure was calculated using Weir's formula. The respiratory quotient (RQ) was calculated as $\mathrm{CO}_{2}$ produced/ $\mathrm{O}_{2}$ consumed.

To determine physical activity the validated Baecke-questionnaire was used (13). To determine whether attitudes towards food intake changed during the experiment, a validated Dutch translation of the Three Factor Eating Questionnaire (TFEQ) was used.

Fasting venous blood samples were taken to analyze concentrations of plasma glucagon-like-peptide-1 (GLP-1), Peptide-YY (PYY) 3-36, insulin, glucose, FFA, TAG, and HDL, LDL and total cholesterol, and creatinin. Plasma was obtained by centrifugation $\left(1500^{*} \mathrm{~g}\right.$ for $10 \mathrm{~min}$ at $\left.4^{\circ} \mathrm{C}\right)$, frozen in liquid nitrogen and stored at $-80^{\circ} \mathrm{C}$ until analysis. Blood samples were collected in tubes containing EDTA to prevent clotting. Blood samples for GLP-1 and PYY analysis were collected in ice-chilled syringes containing $20 \mu \mathrm{l}$ of dipeptidyl peptidase-IV (DPP-IV) inhibitor (Linco Research Inc., St. Charles, Missouri, USA) to prevent degradation. Blood samples for 
PYY analysis were mixed with Trasylol (Bayer Diagnostics Europe Ltd, The Netherlands). Concentrations of active GLP-1 were measured by ELISA (EGLP-35K; Linco Research Inc., ST Charles, Missouri, USA). Concentrations of PYY and insulin were measured by RIA (Linco Research Inc., St Charles, Missouri, USA; Insulin RIA100; Kabi-Pharmacia, Uppsala, Sweden). Glucose concentrations were measured using the hexokinase method (Glucose HK 125 kit; ABX diagnostics, Montpellier, France). HOMA-index was calculated by glucose $(\mathrm{mmol} / \mathrm{L}) *$ insulin (mUnits/L)/22.5. Concentrations of FFA were determined with the Wako NEFA C-kit (Wako chemicals, Neuss, Germany). Concentrations of TAG were measured using the GPO-trinder kit (Sigma Diagnostics Inc., St Louis, MO, USA). Total cholesterol was measured with the cholesterol 100 kit (ABX diagnostics, Montpellier, France) and HDL cholesterol with a combination of the cholesterol 100 kit and the HDL-C kit (Roche Diagnostics GmBH, Mannheim, Germany). LDL cholesterol was calculated according to the Friedewald formula (14).

Urine samples were collected for 24 hours in containers with $10 \mathrm{~mL} \mathrm{H}_{2} \mathrm{SO}_{4}$ to prevent nitrogen loss through evaporation. Volume and nitrogen concentration were measured, the latter with a nitrogen analyzer (CHN-O-Rapid; Heraeus, Hanau, Germany).

\section{Statistical analysis}

Data are presented as means with standard deviations unless otherwise stated. Treatment over time differences between the SSP- and SP-group were tested by ANCOVA with baseline values as covariate and changes over time within groups compared to baseline with repeated-measures ANOVA with Bonferroni post hoc corrections. Differences were regarded as significant if $p<0.05$. All analyses were performed with the Statistical Package for the Social Sciences (SPSS) version 16.0.2 for Macintosh OS X.

\section{RESULTS}

\section{Protein intake}

Protein intake, determined according to 24-hour urinary nitrogen, was significantly higher in the supra-sustained-protein (SSP) diet compared to the sustained-protein (SP) diet in all 4 phases (95\%CI 23 to 45,18 to 47,23 to 51 and 17 to $52 \mathrm{~g}, \mathrm{p}<0.001$ ). Baseline protein intake did not differ between groups (SP; $71 \pm 24 \mathrm{~g}$ or $0.8 \pm 0.3 \mathrm{~g} / \mathrm{kgBM}$ and SSP; $81 \pm 31 \mathrm{~g}$ or $0.9 \pm 0.3 \mathrm{~g} / \mathrm{kgBM}$ ).

The SP-diet resulted in protein intakes comparable with baseline during phases 1,2 and $3 ; 70 \pm 16,64 \pm 21$ and $61 \pm 20 \mathrm{~g}$ or $0.8 \pm 0.2,0.8 \pm 0.3$ and $0.8 \pm 0.3 \mathrm{~g}$ per actual $\mathrm{kg}$ body weight with meal substitutes as protein source and prescribed energy intakes of $100 \%$, $33 \%$ and $67 \%$ respectively. Thus, subjects of the SP-group were able to maintain their intake of daily protein requirement, even with energy restriction up to $-67 \%$. The ad libitum protein intake additional to the meal substitutes during phase 4 resulted in a significantly increased protein intake of $75 \pm 25 \mathrm{~g} / \mathrm{d}$ or $1.0 \pm 0.4 \mathrm{~g}$ per actual $\mathrm{kg}$ body weight $(\mathrm{p}<0.05)$.

The SSP-diet resulted in significantly increased protein intakes compared to baseline during all phases; $104 \pm 26,97 \pm 29,98 \pm 26$ and $109 \pm 31$ g or $1.2 \pm 0.3,1.2 \pm 0.3$, 
$1.2 \pm 0.3$ and $1.3 \pm 0.4 \mathrm{~g}$ per actual $\mathrm{kg}$ body weight $(\mathrm{p}<0.05)$. Thus, subjects of the SSPgroup were able to increase their absolute protein intake, resulting in higher intakes compared to the SP-group during the 6 months of intervention (treatment over time between groups in all 4 phases; $95 \%$ CI 21 to 43,15 to 40,14 to 41 and 10 to $47 \mathrm{~g}$, $\mathrm{p}<0.005)$.
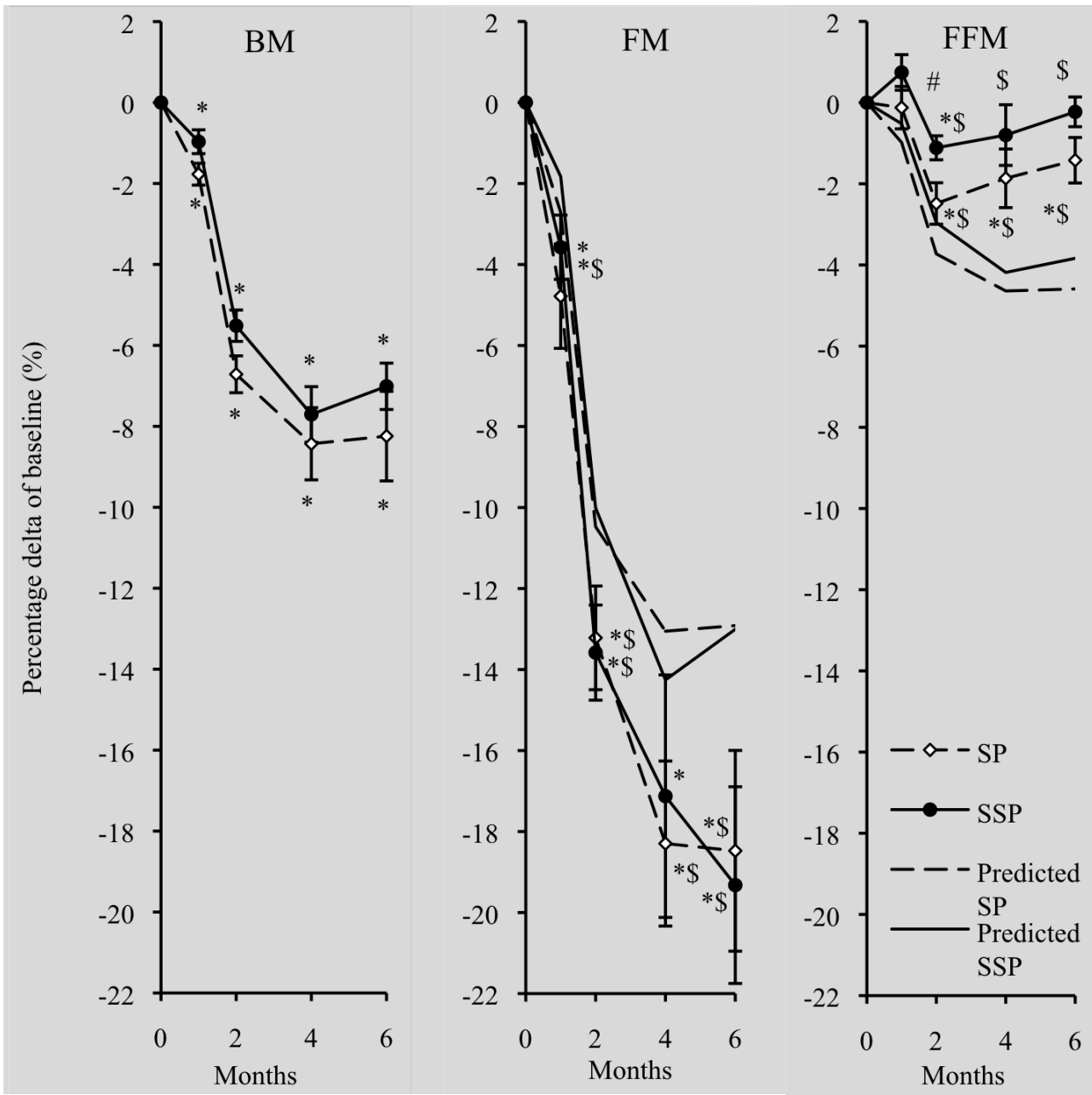

Figure 4.1. Mean and SEM of body weight, measured and predicted fat mass (1/3 of the decrease in body weight) and measured and predicted fat free mass ( $2 / 3$ of the decrease in body weight)

$* \mathrm{p}<0.05$; changes over time compared to baseline within groups.

$\#$ p $<0.05$; treatment over time between groups, sustained-protein (SP) vs. supra-sustained-protein (SSP).

$\$ p<0.05$; measured vs. predicted fat mass or fat free mass. 


\section{Body weight and body composition}

Baseline values of and changes over time in body weight and BMI did not differ between groups. Both groups decreased in body weight and BMI after 6 months compared to baseline (phases $1+2+3+4, \mathrm{p}<0.001$, Table 4.2). Furthermore, the decrease of body weight and BMI was significant in phase 1, 2 and 3 (SP; $-2 \pm 2,-5 \pm 2$, $-2 \pm 3$ and SSP; $-1 \pm 1,-5 \pm 2,-2 \pm 2 \%$ change in body weight of start-value phase 1,2 and 3 respectively, $\mathrm{p}<0.05)$.

Baseline values of fat free mass, fat mass and fat percentage did not differ between groups. Both groups decreased in fat mass and fat percentage after 6 months compared to baseline $(\mathrm{p}<0.001)$. Furthermore, the decrease in fat mass and fat percentage was in both groups significant in phase 1 and 2 (SP; $-5 \pm 7,-8 \pm 6$, and SSP; $-4 \pm 4,-10 \pm 6$ $\%$ change in fat mass of start-value phase 1 and 2 respectively, $\mathrm{p}<0.05$ ). Also fat free mass decreased in the strict energy restriction phase 2 of $-67 \%$ energy intake (SP; $-2 \pm 3$ and SSP; $-2 \pm 2 \%$ change in fat free mass of start-value phase $2, \mathrm{p}<0.05)$. However, fat free mass decreased less and fat mass decreased more in both groups compared to their predicted decreases $(\mathrm{p}<0.001$, Figure 4.1); predicted decrease in fat free mass is $33 \%$ and predicted decrease in fat mass is $67 \%$ of the decrease in body weight (1). The proportion of decreased fat free mass on decreased body weight was $22 \%$ for SP and $12 \%$ for SSP after the strict energy restriction phase 2, and 14\% for SP and 7\% for SSP after the mild energy restriction phase 3. Furthermore, the SSP-group decreased less in fat free mass compared to the SP-group after 2 months (phase $1+2$ SSP vs. SP; $-1 \pm 1$ vs. $-2 \pm 3 \%$ change in fat free mass of baseline, $\mathrm{p}<0.05)$. Moreover, fat free mass did not change in the SSP-group but decreased slightly in the SP-group after 6 months compared to baseline $(\mathrm{p}<0.05)$.

\section{Energy expenditure}

Resting energy expenditure (REE) was linearly related to fat free mass at baseline and after all 3 phases $(p<0.001$, Figure 4.2). The regression line of the SP-group shifts down as body-weight loss progresses, indicating that REE decreases for a certain fat free mass as body weight decreases due to energy intake restriction. Compared to the SP-group, the regression line of the SSP-group shifts less. Predicted REE was calculated based on the regression equation of the whole study population at baseline; $\mathrm{REE}=0.078 \mathrm{FFM}+0.038 \mathrm{FM}+1.435\left(\mathrm{r}^{2}=0.782, \mathrm{n}=57\right)$ by filling in the fat free mass (FFM) and fat mass (FM) values from the respective phase. Measured and predicted REE did not differ in the SSP-group. In the SP-group, measured REE was lower compared to the predicted REE after 2 and 4 months $(-0.3$ and $-0.2 \mathrm{MJ} /$ day; $95 \% \mathrm{CI}$ -0.5 to -0.1 and -0.4 to $-0.1 \mathrm{MJ} /$ day, $\mathrm{p}<0.01)$. Therefore, the SP-group differed significantly more in measured - predicted REE compared to the SSP-group after 2 months ( -0.3 vs. $0.0 \mathrm{MJ} /$ day; $95 \%$ CI 0.1 to $0.6 \mathrm{MJ} /$ day, $\mathrm{p}<0.05)$. Overall, the reduction of REE over time was absent in the SSP-group and small, but significantly present in the SP-group.

Baseline RQ did not differ between groups. Both groups did not change in RQ over time after 4 months. However, RQ decreased after 2 months compared to baseline $(\mathrm{p}<0.01$, Table 4.2). Furthermore, the decrease in RQ was significant in both groups in phase 2 (SP; $-2 \pm 5$ and SSP; $-5 \pm 5 \%$ change in RQ of start-value phase $2, \mathrm{p}<0.05)$, 
reversed significantly in the SP-group in phase 3 (SP; $4 \pm 6 \%$ change in RQ of startvalue phase $3, \mathrm{p}<0.05$ ), but did not reverse in the SSP-group.

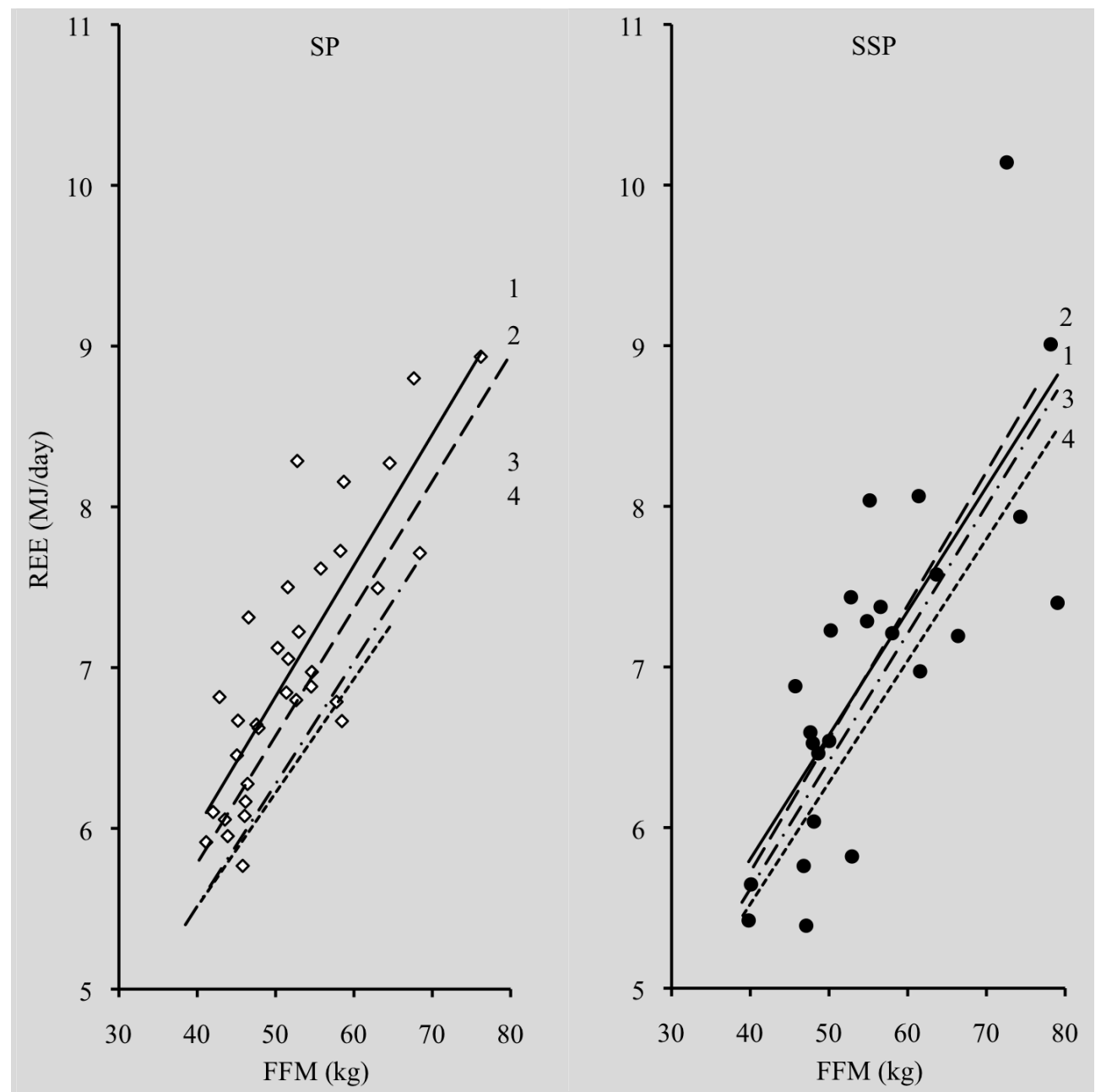

Figure 4.2. Resting energy expenditure as a function of fat free mass plotted at baseline and linear regression lines at baseline and of phase 1,2 and $3(1,2,3,4)$

Sustained-protein (SP) regression line $\quad 1 ; \mathrm{y}=0.082 \mathrm{x}+2.745, \mathrm{r}^{2}=0.69$

$2 ; \mathrm{y}=0.079 \mathrm{x}+2.618, \mathrm{r}^{2}=0.66$

$3 ; \mathrm{y}=0.076 \mathrm{x}+2.477, \mathrm{r}^{2}=0.60$

$4 ; y=0.071 x+2.672, r^{2}=0.50$

Supra-sustained-protein (SSP) regression line 1; $y=0.077 \mathrm{x}+2.716, \mathrm{r}^{2}=0.60$

$2 ; y=0.083 x+2.403, r^{2}=0.50$

$3 ; \mathrm{y}=0.080 \mathrm{x}+2.439, \mathrm{r}^{2}=0.75$

4; $y=0.076 x+2.492, r^{2}=0.70$ 


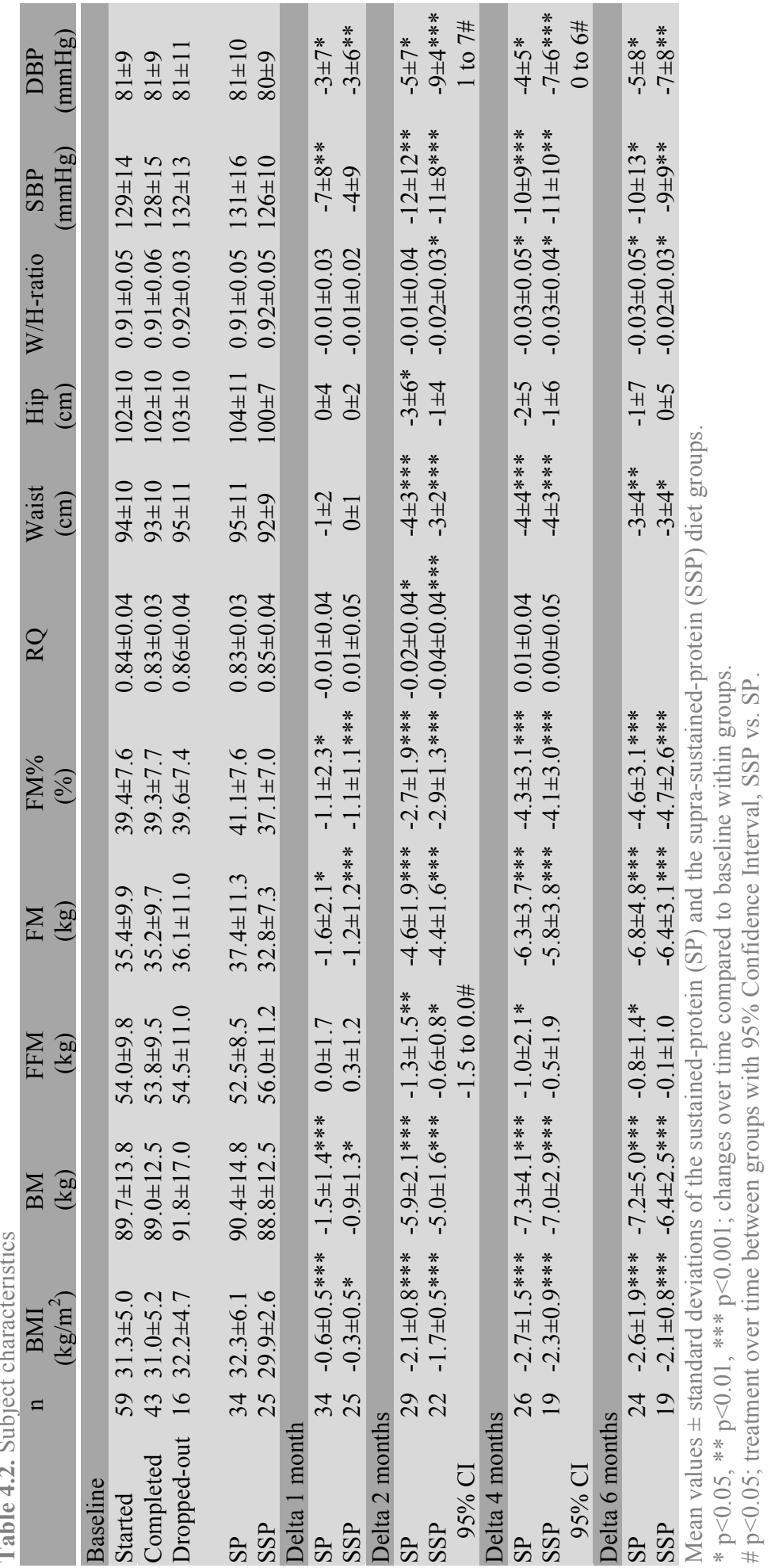




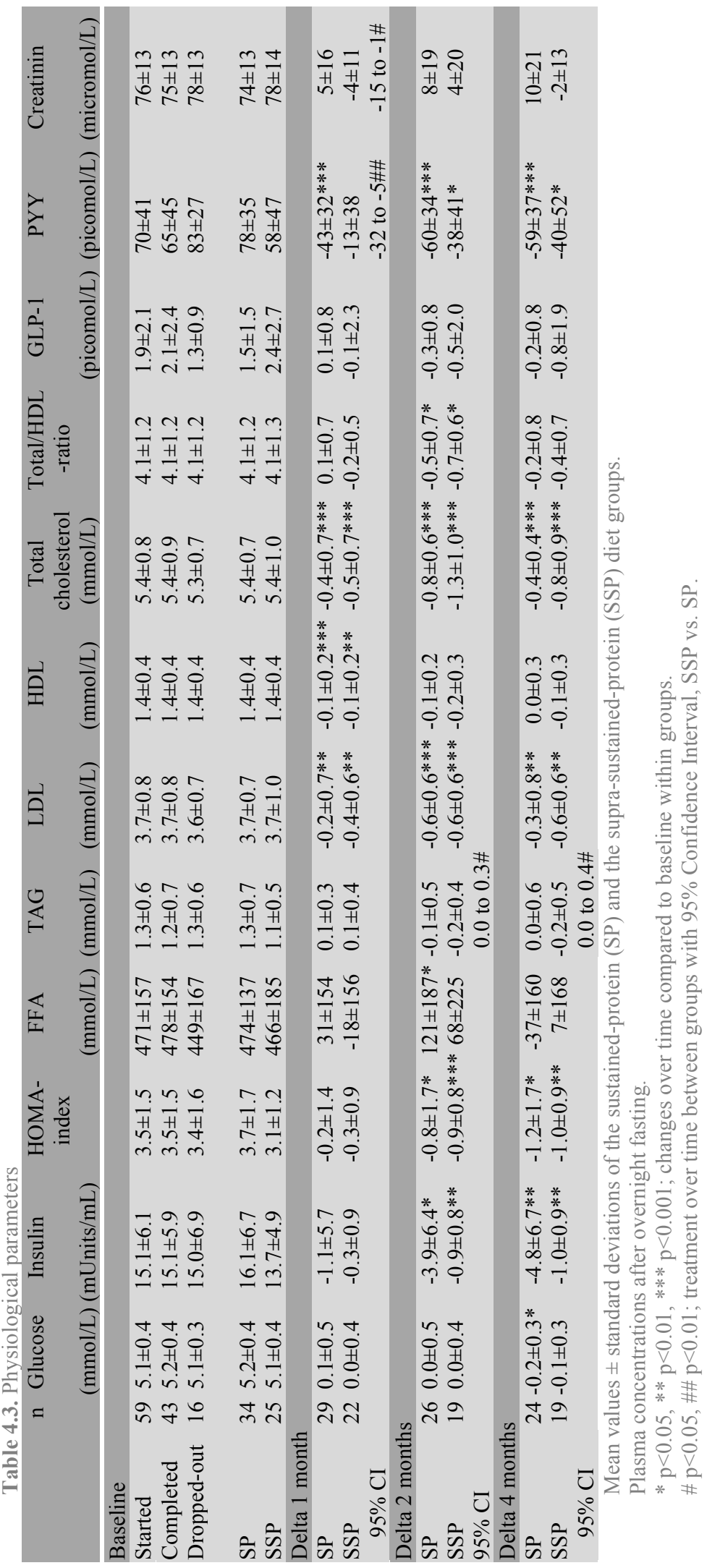




\section{Waist- and hip-circumference}

Baseline values of and changes over time in waist- and hip-circumference and waisthip ratio did not differ between groups. Both groups decreased in waist in phase 2 (SP; $-3 \pm 2$ and SSP; $-3 \pm 2, \%$ change in waist of start-value phase $2 ; \mathrm{p}<0.05$ ) and reversed in phase 4 (SP; $1 \pm 3$ and SSP; $2 \pm 3 \%$ change in waist of start-value phase 4 ; $\mathrm{p}<0.05)$. Furthermore, waist circumference and waist-hip ratio decreased after 6 months compared to baseline $(\mathrm{p}<0.05$, Table 4.2)

\section{Physiological characteristics}

Baseline values of and changes over time in fasted morning plasma of glucose and insulin, and HOMA-index did not differ between groups. Both groups decreased in insulin and HOMA-index after 4 months compared to baseline $(\mathrm{p}<0.05$, Table 4.3). Furthermore, insulin decreased significantly in phase 2 (SP; $-15 \pm 27$ and SSP; $-17 \pm 30$ $\%$ change in insulin of start-value phase $2 ; \mathrm{p}<0.05)$. Glucose decreased after 4 months in the SP-group $(\mathrm{p}<0.05)$. Overall, decreases in insulin $(\mathrm{r}=0.347, \mathrm{p}=0.023)$ and HOMAindex $(r=0.352, p=0.021)$ were related to decrease in body weight.

Baseline values of and changes over time in fasted morning plasma of FFA, HDL, LDL and total cholesterol, and baseline values of TAG did not differ between groups. Both groups decreased in LDL and total cholesterol after 4 months compared to baseline $(\mathrm{p}<0.01)$. Furthermore, LDL and total cholesterol decreased significantly in phase 1 and 2 (LDL SP; $-9 \pm 16,-7 \pm 16$ and SSP; $-10 \pm 15,-12 \pm 15$, and total cholesterol SP; $-8 \pm 12,-4 \pm 12$ and SSP; $-9 \pm 13,-10 \pm 12 \%$ change of start-value phase 1 and 2 respectively, $\mathrm{p}<0.05$ ), and reversed significantly in phase 3 (LDL SP; $12 \pm 24$ and SSP; $24 \pm 24$, and total cholesterol SP; $11 \pm 13$ and SSP; $17 \pm 18 \%$ change of start-value phase $3, \mathrm{p}<0.05)$. FFA, TAG and HDL concentrations did not change over time after 4 months. However, TAG decreased less in the SP-compared to the SSP-group after 2 and 4 months $(\mathrm{p}<0.05)$. Overall, decrease in TAG was related to decrease in body weight $(\mathrm{r}=0.325, \mathrm{p}=0.031)$.

Baseline values of and changes over time in systolic blood pressure, and baseline values of diastolic blood pressure did not differ between groups. Both groups decreased in systolic and diastolic blood pressure after 6 months $(p<0.05$, Table 4.2). Furthermore, diastolic blood pressure decreased less in the SP-compared to the SSPgroup after 2 and 4 months $(\mathrm{p}<0.05)$. Overall, decrease in fat mass was related to decreases in systolic $(\mathrm{r}=0.324, \mathrm{p}=0.047)$ and diastolic blood pressure $(\mathrm{r}=0.375$, $\mathrm{p}=0.020)$.

\section{Physical activity and eating behavior}

Baseline values of and changes over time in physical activity scores of the Baeckequestionnaire did not differ between groups. Both groups did not change in total physical activities over time during the 6 months of intervention.

Baseline values of and changes over time in Three Factor Eating Questionnaire (TFEQ) score of dietary restraint (F1), disinhibition (F2) and hunger (F3) did not differ between groups. Both groups increased in F1-score and decreased in F2- and F3-scores after 6 months $(\mathrm{p}<0.05$, Table 4.4). Overall, decrease in F3-score was related to decreases in body weight $(\mathrm{r}=0.340, \mathrm{p}=0.027)$, fat mass $(\mathrm{r}=0.398, \mathrm{p}=0.015)$ and fat 
percentage $(\mathrm{r}=0.414, \mathrm{p}=0.011)$, and decrease in $\mathrm{F} 2$-score was related to decrease in body weight $(\mathrm{r}=0.313, \mathrm{p}=0.043)$.

\section{Hunger and satiety}

Baseline values of and changes over time in visual analogue scores (VAS) and fasted morning plasma of GLP-1 concentrations, and baseline values of PYY concentrations did not differ between groups. Both groups did not change in VAS of hunger, desire to eat, prospective food consumption, thirst, desire to drink, prospective drink consumption, fullness and satiety over time during the 6 months of intervention. Furthermore, GLP-1 concentrations did not change over time after 4 months. However, both groups decreased in PYY concentrations after 4 months compared to baseline $(\mathrm{p}<0.05$, Table 4.3). Furthermore, the SP-group decreased significantly more in PYY concentrations compared to the SSP-group in phase $1(\mathrm{p}<0.01)$.

\section{Kidney function}

Baseline values of fasted morning serum creatinin concentrations did not differ between groups. Change in creatinin over time differed between the SP- and the SSPgroup after 1 month (SP vs. SSP; $8 \pm 22$ vs. $-4 \pm 12 \%$ change in creatinin of baseline, $\mathrm{p}<0.05)$.

Table 4.4. Physical activity and eating behavior

\begin{tabular}{|c|c|c|c|c|c|c|c|c|}
\hline & $\mathrm{n}$ & Work $^{1}$ & Sport $^{1}$ & Leisure time $^{1}$ & Baecke $^{1}$ & TFEQ F $1^{2}$ & TFEQ F $2^{3}$ & TFEQ F $3^{4}$ \\
\hline \multicolumn{9}{|l|}{ Baseline } \\
\hline Started & 59 & $2.7 \pm 0.6$ & $2.6 \pm 0.8$ & $3.0 \pm 0.6$ & $8.3 \pm 1.4$ & $8.2 \pm 4.3$ & $5.9 \pm 2.5$ & $4.6 \pm 2.8$ \\
\hline Completed & 43 & $2.7 \pm 0.6$ & $2.6 \pm 0.9$ & $3.0 \pm 0.6$ & $8.3 \pm 1.5$ & $9.2 \pm 4.3$ & $5.8 \pm 2.3$ & $4.6 \pm 3.0$ \\
\hline Dropped-out & 16 & $2.7 \pm 0.5$ & $2.6 \pm 0.5$ & $3.2 \pm 0.5$ & $8.5 \pm 0.9$ & $5.4 \pm 2.9$ & $6.3 \pm 2.9$ & $4.4 \pm 2.4$ \\
\hline SP & 34 & $2.8 \pm 0.5$ & $2.6 \pm 1.0$ & $3.1 \pm 0.6$ & $8.4 \pm 1.4$ & $8.2 \pm 4.1$ & $6.2 \pm 2.7$ & $4.7 \pm 3.0$ \\
\hline SSP & 25 & $2.6 \pm 0.6$ & $2.6 \pm 0.6$ & $3.0 \pm 0.5$ & $8.1 \pm 1.3$ & $8.2 \pm 4.5$ & $5.5 \pm 2.1$ & $4.4 \pm 2.7$ \\
\hline \multicolumn{9}{|c|}{ Delta 1 month } \\
\hline SP & 34 & $0.0 \pm 0.3$ & $0.1 \pm 0.5$ & $0.1 \pm 0.3$ & $0.2 \pm 0.6$ & $0.9 \pm 3.4$ & $-0.6 \pm 1.8$ & $-0.3 \pm 1.9$ \\
\hline SSP & 25 & $0.0 \pm 0.3$ & $0.0 \pm 0.3$ & $0.0 \pm 0.5$ & $0.1 \pm 0.7$ & $1.0 \pm 2.2 *$ & $-0.1 \pm 1.3$ & $-0.1 \pm 1.8$ \\
\hline \multicolumn{9}{|c|}{ Delta 2 months } \\
\hline SP & 29 & $0.0 \pm 0.3$ & $0.1 \pm 0.7$ & $0.2 \pm 0.3$ & $0.2 \pm 0.9$ & $2.3 \pm 3.9 *$ & $-1.4 \pm 2.2 *$ & $-1.7 \pm 3.0 *$ \\
\hline SSP & 22 & $0.0 \pm 0.2$ & $0.1 \pm 0.4$ & $0.1 \pm 0.6$ & $0.2 \pm 0.8$ & $1.8 \pm 3.0 *$ & $-0.8 \pm 1.9$ & $-0.9 \pm 2.3$ \\
\hline \multicolumn{9}{|c|}{ Delta 4 months } \\
\hline $\mathrm{SP}$ & 26 & $-0.1 \pm 0.3$ & $0.0 \pm 0.8$ & $0.2 \pm 0.4^{*}$ & $0.1 \pm 1.2$ & $1.8 \pm 3.8^{*}$ & $-1.4 \pm 2.1 *$ & $-1.7 \pm 3.0 *$ \\
\hline SSP & 19 & $0.0 \pm 0.3$ & $0.1 \pm 0.4$ & $0.1 \pm 0.6$ & $0.2 \pm 0.7$ & $2.8 \pm 4.1 * *$ & $-0.9 \pm 1.4^{*}$ & $-1.9 \pm 2.7 *$ \\
\hline \multicolumn{9}{|c|}{ Delta 6 months } \\
\hline SP & 24 & $-0.1 \pm 0.3$ & $-0.2 \pm 0.8$ & $0.3 \pm 0.4 * *$ & $0.0 \pm 1.1$ & $2.2 \pm 4.1^{*}$ & $-1.7 \pm 2.4^{*}$ & $-1.8 \pm 2.6^{*}$ \\
\hline SSP & 19 & $0.0 \pm 0.3$ & $0.0 \pm 0.3$ & $0.1 \pm 0.3$ & $0.1 \pm 0.6$ & $3.3 \pm 3.0 * *$ & $-0.7 \pm 1.5^{*}$ & $-1.9 \pm 2.9 *$ \\
\hline
\end{tabular}

Mean values \pm standard deviations of the sustained protein (SP) and the supra-sustained protein (SSP) diet group.

$* \mathrm{p}<0.05, * * \mathrm{p}<0.01$; changes over time compared to baseline within groups.

No treatment over time between groups.

${ }^{1}$ The Baecke total activity index and its activity sub-scores of sport, leisure time and work.

${ }^{2}$ A measure of cognitive restraint of the three-factor eating questionnaire (TFEQ); minimum score 0 , maximum score 21; cut-off point fort the Dutch population 9. Values greater than 9 indicate cognitive restraint eating.

${ }^{3}$ A measure of disinhibition or emotional eating of the TFEQ; minimum score 0 , maximum score 14.

${ }^{4}$ A general feeling of hunger of the TFEQ; minimum score 0 , maximum score 14 . 


\section{DISCUSSION}

Reduction of body weight, fat mass and fat percentage was not affected by the extra elevation above sustained-protein intake during different phases of energy restriction. However, the extra protein intake of the supra-sustained-protein diet was more successful in sparing fat free mass. Fat free mass of the supra-sustained-protein group decreased significantly less during the strict energy restriction phase of $-67 \%$ compared to the sustained-protein group. Furthermore, fat free mass regained in the suprasustained-protein group during the mild energy restriction phases of $-33 \%$, so that it did not differ from baseline after 6 months, despite a reduction of 7\% in body weight. Both protein diets were effective in sparing fat free mass during energy restriction, as actual fat free mass decreased less compared to the predicted losses based upon amount of body-weight loss. The proportion of decreased fat free mass on decreased body weight was $22 \%$ and $14 \%$ for sustained-protein intake and $12 \%$ and $7 \%$ for supra-sustainedprotein intake after strict and mild energy restriction respectively compared to $33 \%$ for energy restricted diets without elevated protein intake (1).

Nitrogen retention is an acute response to a protein rich meal $(15,16)$. Protein rich diets up to 50-days still result in retention of nitrogen (17), and therefore increase the systemic amino acid content. As systemic amino acid availability influences muscleprotein synthesis $(18,19)$ nitrogen retention results into net muscle-protein synthesis (20). Indeed, elevated-protein diets over a longer phase of time result in sparing of fat free mass during energy restriction with protein intakes of $1.0-1.5 \mathrm{~g}$ protein $/ \mathrm{kg}$ body weight $(5,21-27)$. Our protocol succeeded in creating a contrast in protein intake between the supra-sustained-protein and sustained-protein diets $(1.2 \mathrm{vs} .0 .8 \mathrm{~g} / \mathrm{kgBM})$. By using 24-hour urine nitrogen content to quantify protein intakes, we calculated the real grams of protein intake and thereby confirmed the presence and magnitude of intervention. This is the only and necessary way to show compliance of protein intake, as it is well known that dietary record methods are prone to misreporting (28). In conclusion, the protein intakes of 1.2 and $0.8 \mathrm{~g} / \mathrm{kgBM}$ result into sparing of fat free mass during loss of body weight, with the intake of $1.2 \mathrm{~g} / \mathrm{kgBM}$ being most successful.

As a result of the more successful sparing of fat free mass of the supra-sustainedprotein diet, resting energy expenditure as a function of fat free mass did not decrease. The supra-sustained-protein diet resulted in sustained resting energy expenditure as a function of fat free mass as was predicted from the relationship of resting energy expenditure with fat free mass during baseline. Successful sparing of fat free mass of the supra-sustained-protein intake hereby facilitates maintenance of reduced body weight, as was shown before $(21-24,29-31)$. Similarly, elevated protein compared to control diets has shown to reduce body weight more successfully after energy restriction of 2 up to 6 months $(4-6,21-27,31,32)$.

Reduction of body weight is facilitated by the high -satiation capacity of protein $(5-7,21)$, that increases compliance to the diet $(6,25,33)$. The negative energy balance of an energy-restricted diet is reinforced by the sustained energy expenditure of elevated-protein diets during body loss (34), due to the high ATP cost of protein synthesis $(35,36)$, and to improved fat oxidation $(37,38)$, which is moreover suggested to reduce appetite $(39,40)$. Subjective feeling of hunger of the TFEQ-questionnaire decreased in both protein diets. Furthermore, decreases in body weight and fat percentage were related to the decrease in subjective feeling of hunger. The amount of 
protein intake sustained the peripheral plasma concentrations of the nutrient-related hormone glucagon-like-peptide-1 during energy restriction. Peptide-YY, however decreased already after the first phase where participants reduced in body weight despite the prescription of $100 \%$ energy intake to reach energy balance. The participants of this weight-loss study were so motivated to decrease their body weight that they had started to do so in the first phase. Consonantly, dietary restraint, a measure of control of food intake by thought and will-power, increased, and disinhibition of control, an incidental inability to resist eating cues, decreased in both groups. Furthermore, the decrease in body weight was related to the decrease in disinhibition. In conclusion, decrease in disinhibition and decrease in hunger reinforce good compliance of the diet resulting in successful reduction of body weight over time.

The metabolic profile was remarkably improved in both groups. Insulin, HOMAindex, LDL and total cholesterol decreased as a result of body-weight loss due to the dietary intervention. As previously, protein-rich energy-restricted diets with successful body-weight loss influenced the metabolic profile positively $(23,24,29,41)$. Still, it is not clear if these beneficial effects on the metabolic profile are driven by reduction of body weight or by the macronutrient composition, i.e. elevated protein intake. Regarding these protein-rich diets, some caution is needed when protein intake is elevated in an absolute sense for a longer phase. There may be adverse effects on the kidney, related to elevated blood pressure. Systolic and diastolic blood pressure decreased as a result of the decrease in body weight, and probably due to elevation in protein intake as the supra-sustained-protein diet resulted in a larger decrease compared to the sustained-protein diet. Sustaining baseline required-protein and the elevatedprotein intake of the supra-sustained-protein diet did not change kidney function parameters over time, as both diets did not result into reduced creatinin clearence of the kidney and remained between normal values of 60 to $120 \mathrm{micromol} / \mathrm{L}$ urinary creatinin over 24 hours. Furthermore, two recent reviews conclude that the link between protein intake and initiation or progression of renal disease lacks evidence in healthy individuals $(37,42)$. The WHO-report no. 935 'Protein and amino acid requirements in human nutrition' states that 'the value accepted for the safe level of protein intake is $0.83 \mathrm{~g} / \mathrm{kg}$ per day'. Furthermore, it states that 'no safe upper limit has been identified, and it is unlikely that intakes of twice the safe level are associated with any risk'. Individuals with sub-clinical renal functioning however, such as individuals with the metabolic syndrome or diabetes mellitus type 2 , and elderly are especially vulnerable for a decrease in kidney function (43).

In conclusion, supra-sustained-rotein and sustained-protein diets during energy restriction reduce body weight and fat percentage equally, while supra-sustainedprotein diet spares more fat free mass in combination with a sustained resting energy expenditure as a function of fat free mass, during loss of body weight.

\section{ACKNOWLEDGMENTS}

We gratefully acknowledge Freeha Faizi for her assistance. The study was supported by Top Institute Food and Nutrition (TIFN, Wageningen, The Netherlands). 


\section{REFERENCES}

1. Westerterp KR, Meijer GA, Kester AD, Wouters L, ten Hoor F. Fat free mass as a function of fat mass and habitual activity level. Int J Sports Med 1992;13:163-6.

2. Halliday D, Hesp R, Stalley SF, Warwick P, Altman DG, Garrow JS. Resting metabolic rate, weight, surface area and body composition in obese women. Int J Obes 1979;3:1-6.

3. Ravussin E, Lillioja S, Anderson TE, Christin L, Bogardus C. Determinants of 24-hour energy expenditure in man. Methods and results using a respiratory chamber. J Clin Invest 1986;78:1568-78.

4. Krieger JW, Sitren HS, Daniels MJ, Langkamp-Henken B. Effects of variation in protein and carbohydrate intake on body mass and composition during energy restriction: a meta-regression 1. Am J Clin Nutr 2006;83:260-74.

5. Lejeune MP, Kovacs EM, Westerterp-Plantenga MS. Additional protein intake limits weight regain after weight loss in humans. Br J Nutr 2005;93:281-9.

6. Weigle DS, Breen PA, Matthys CC, et al. A high-protein diet induces sustained reductions in appetite, ad libitum caloric intake, and body weight despite compensatory changes in diurnal plasma leptin and ghrelin concentrations. Am J Clin Nutr 2005;82:41-8.

7. Westerterp-Plantenga MS, Rolland V, Wilson SA, Westerterp KR. Satiety related to $24 \mathrm{~h}$ diet induced thermogenesis during high protein/carbohydrate vs high fat diets measured in a respiration chamber. Eur J Clin Nutr 1999;53:495-502.

8. Simpson SJ, Raubenheimer D. Obesity: the protein leverage hypothesis. Obes Rev 2005;6:13342.

9. Harris JA, Benedict FG. A Biometric Study of Human Basal Metabolism. Proc Natl Acad Sci U S A 1918;4:370-3.

10. Dempster P, Aitkens S. A new air displacement method for the determination of human body composition. Med Sci Sports Exerc 1995;27:1692-7.

11. Westerterp KR, Wouters L, van Marken Lichtenbelt WD. The Maastricht protocol for the measurement of body composition and energy expenditure with labeled water. Obes Res 1995;3 Suppl 1:49-57.

12. siri W. Body composition from fluid spaces and density: analysis of methods. . In: Henschel A, ed. Techniques for Measuring Body Composition. Washington DC: Natl.Acad.Sci.Natl.Res.Council, 1961:223-224.

13. Philippaerts RM, Westerterp KR, Lefevre J. Doubly labelled water validation of three physical activity questionnaires. Int J Sports Med 1999;20:284-9.

14. Friedewald WT, Levy RI, Fredrickson DS. Estimation of the concentration of low-density lipoprotein cholesterol in plasma, without use of the preparative ultracentrifuge. Clin Chem 1972;18:499-502.

15. Garlick PJ, McNurlan MA, Patlak CS. Adaptation of protein metabolism in relation to limits to high dietary protein intake. Eur J Clin Nutr 1999;53 Suppl 1:S34-43.

16. Pannemans DL, Wagenmakers AJ, Westerterp KR, Schaafsma G, Halliday D. Effect of protein source and quantity on protein metabolism in elderly women. Am J Clin Nutr 1998;68:1228-35.

17. Oddoye EA, Margen S. Nitrogen balance studies in humans: long-term effect of high nitrogen intake on nitrogen accretion. J Nutr 1979;109:363-77.

18. Paddon-Jones D, Sheffield-Moore M, Zhang XJ, et al. Amino acid ingestion improves muscle protein synthesis in the young and elderly. Am J Physiol Endocrinol Metab 2004;286:E321-8.

19. Bohe J, Low A, Wolfe RR, Rennie MJ. Human muscle protein synthesis is modulated by extracellular, not intramuscular amino acid availability: a dose-response study. J Physiol 2003;552:315-24.

20. Harber MP, Schenk S, Barkan AL, Horowitz JF. Effects of dietary carbohydrate restriction with high protein intake on protein metabolism and the somatotropic axis. J Clin Endocrinol Metab 2005;90:5175-81.

21. Westerterp-Plantenga MS, Lejeune MP, Nijs I, van Ooijen M, Kovacs EM. High protein intake sustains weight maintenance after body-weight loss in humans. Int J Obes Relat Metab Disord 2004;28:57-64. 
22. Farnsworth E, Luscombe ND, Noakes M, Wittert G, Argyiou E, Clifton PM. Effect of a highprotein, energy-restricted diet on body composition, glycemic control, and lipid concentrations in overweight and obese hyperinsulinemic men and women. Am J Clin Nutr 2003;78:31-9.

23. Layman DK, Boileau RA, Erickson DJ, et al. A reduced ratio of dietary carbohydrate to protein improves body composition and blood lipid profiles during weight loss in adult women. J Nutr 2003;133:411-7.

24. Parker B, Noakes M, Luscombe N, Clifton P. Effect of a high-protein, high-monounsaturated fat weight loss diet on glycemic control and lipid levels in type 2 diabetes. Diabetes Care 2002;25:425-30.

25. Skov AR, Toubro S, Ronn B, Holm L, Astrup A. Randomized trial on protein vs carbohydrate in ad libitum fat reduced diet for the treatment of obesity. Int J Obes Relat Metab Disord 1999;23:528-36.

26. Piatti PM, Monti F, Fermo I, et al. Hypocaloric high-protein diet improves glucose oxidation and spares lean body mass: comparison to hypocaloric high-carbohydrate diet. Metabolism 1994;43:1481-7.

27. Hoffer LJ, Bistrian BR, Young VR, Blackburn GL, Matthews DE. Metabolic effects of very low calorie weight reduction diets. J Clin Invest 1984;73:750-8.

28. Westerterp KR, Goris AH. Validity of the assessment of dietary intake: problems of misreporting. Curr Opin Clin Nutr Metab Care 2002;5:489-93.

29. Baba NH, Sawaya S, Torbay N, Habbal Z, Azar S, Hashim SA. High protein vs high carbohydrate hypoenergetic diet for the treatment of obese hyperinsulinemic subjects. Int J Obes Relat Metab Disord 1999;23:1202-6.

30. Lejeune MP, Kovacs EM, Westerterp Plantenga MS. Additional protein intake limits weight regain after weight loss in humans. Br J Nutr 2005;93:281-9.

31. Deibert P, Konig D, Schmidt-Trucksaess A, et al. Weight loss without losing muscle mass in preobese and obese subjects induced by a high-soy-protein diet. Int J Obes Relat Metab Disord 2004;28:1349-52.

32. Noakes M, Keogh JB, Foster PR, Clifton PM. Effect of an energy-restricted, high-protein, lowfat diet relative to a conventional high-carbohydrate, low-fat diet on weight loss, body composition, nutritional status, and markers of cardiovascular health in obese women. Am J Clin Nutr 2005;81:1298-306.

33. Due A, Toubro S, Skov AR, Astrup A. Effect of normal-fat diets, either medium or high in protein, on body weight in overweight subjects: a randomised 1-year trial. Int $\mathrm{J}$ Obes Relat Metab Disord 2004;28:1283-90.

34. Luscombe-Marsh ND, Noakes M, Wittert GA, Keogh JB, Foster P, Clifton PM. Carbohydraterestricted diets high in either monounsaturated fat or protein are equally effective at promoting fat loss and improving blood lipids. Am J Clin Nutr 2005;81:762-72.

35. Tessari P, Kiwanuka E, Zanetti M, Barazzoni R. Postprandial body protein synthesis and amino acid catabolism measured with leucine and phenylalanine-tyrosine tracers. Am J Physiol Endocrinol Metab 2003;284:E1037-42.

36. van Milgen J. Modeling biochemical aspects of energy metabolism in mammals. J Nutr 2002;132:3195-202.

37. Halton TL, Hu FB. The effects of high-protein diets on thermogenesis, satiety and weight loss: a critical review. J Am Coll Nutr 2004;23:373-85.

38. Westerterp-Plantenga MS. The significance of protein in food intake and body weight regulation. Curr Opin Clin Nutr Metab Care 2003;6:635-8.

39. Langhans W. Fatty acid oxidation in the energostatic control of eating--a new idea. Appetite 2008;51:446-51.

40. Scharrer E. Control of food intake by fatty acid oxidation and ketogenesis. Nutrition 1999;15:704-14.

41. Wolfe BM, Piche LA. Replacement of carbohydrate by protein in a conventional-fat diet reduces cholesterol and triglyceride concentrations in healthy normolipidemic subjects. Clin Invest Med 1999;22:140-8. 
42. Martin WF, Armstrong LE, Rodriguez NR. Dietary-protein intake and renal function. Nutr Metab (Lond) 2005;2:25.

43. Hoy WE, Hughson MD, Bertram JF, Douglas-Denton R, Amann K. Nephron number, hypertension, renal disease, and renal failure. J Am Soc Nephrol 2005;16:2557-64.

44. Hegsted M, Linkswiler HM. Long-term effects of level of protein intake on calcium metabolism in young adult women. J Nutr 1981;111:244-51.

45. Kerstetter JE, O'Brien KO, Caseria DM, Wall DE, Insogna KL. The impact of dietary protein on calcium absorption and kinetic measures of bone turnover in women. J Clin Endocrinol Metab 2005;90:26-31.

46. Skov AR, Toubro S, Bulow J, Krabbe K, Parving HH, Astrup A. Changes in renal function during weight loss induced by high vs low-protein low-fat diets in overweight subjects. Int $\mathrm{J}$ Obes Relat Metab Disord 1999;23:1170-7.

47. Pannemans DL, Schaafsma G, Westerterp KR. Calcium excretion, apparent calcium absorption and calcium balance in young and elderly subjects: influence of protein intake. Br J Nutr 1997;77:721-9.

48. Bonjour JP. Dietary protein: an essential nutrient for bone health. J Am Coll Nutr 2005;24:526S$36 \mathrm{~S}$.

49. Heaney RP. Protein intake and the calcium economy. J Am Diet Assoc 1993;93:1259-60.

50. Weikert C, Walter D, Hoffmann K, Kroke A, Bergmann MM, Boeing H. The relation between dietary protein, calcium and bone health in women: results from the EPIC-Potsdam cohort. Ann Nutr Metab 2005;49:312-8.

51. Barzel US, Massey LK. Excess dietary protein can adversely affect bone. J Nutr 1998;128:10513. 



\section{PROTEIN INTAKE INDUCED CHANGES IN BODY COMPOSITION IN ENERGY BALANCE}

StiJn Soenen AND MARgriet S WeSterterp-Plantenga

SUBMITTED FOR PUBLICATION 


\section{ABSTRACT}

\section{Objective}

To examine if elevated protein intake in energy balance influences body composition.

\section{Design}

The 4-compartment body composition and blood parameters were assessed before and after a 3-month eucaloric dietary-intervention of $2 \mathrm{MJ} / \mathrm{d}$ supplements of protein, or carbohydrate and fat, as exchange with $2 \mathrm{MJ} / \mathrm{d}$ of habitual energy intake. Protein intake was calculated from 24-hour urinary nitrogen.

\section{Results}

Subjects were in energy balance without changing their body weight (BM) and physical activity. The protein group $(n=12)$ had a higher protein intake vs. control $(n=4)(80 \pm 21$ vs. $59 \pm 11 \mathrm{~g}, \mathrm{p}<0.05)$, which resulted in a decrease in fat percentage in the protein and not the control group $(\mathrm{p}<0.05)$. Protein intake increased in the protein group $(11 \pm 14 \mathrm{~g}$ or $0.1 \pm 0.2 \mathrm{~g} / \mathrm{kgBM}, \mathrm{p}<0.05)$ and resulted in increased fat free mass $(0.9 \pm 0.6 \mathrm{~kg}, \mathrm{p}<0.01)$, and in decreased fat mass and fat percentage $(-0.6 \pm 0.8 \mathrm{~kg}$, $\mathrm{p}<0.05 ;-1.0 \pm 1.1 \%, \mathrm{p}<0.05)$.

\section{Conclusion}

Increased protein intake during 3 months in energy balance and with stable physical activity results in a more favorable body composition, i.e. an increased fat free mass at the cost of fat mass.

\section{Keywords}

protein intake, fat mass, fat free mass, energy balance 


\section{INTRODUCTION}

As overweight and obesity are associated with increased risk of several diseases, it is relevant to prevent weight gain during lifetime. Body weight gains as a result of a positive energy balance, whch occurs when energy intake exceeds energy expenditure. Maintenance of body weight is achieved when energy intake is adjusted to energy expenditure. Energy intake is mainly influenced by appetite and satiety whereas energy expenditure is mainly influenced by body composition and thermogenesis. In this respect, high-protein diets have gained considerable interest. Of all macronutrients, proteins have shown to be the most satiating (1-4), to be the most thermogenic $(4,5)$, and to result in increased weight loss and greater fat loss during energy restriction, and thereby promoting a higher ratio of fat free mass to fat mass $(3,6-10)$. This fat free mass sparing effect from protein rich diets has been shown during interventions for body-weight loss $(3,6,7,9,11)$ and body-weight maintenance thereafter $(3,7,11)$. We propose that this effect is instrumental in weight maintenance, and since it is the main determinant of energy expenditure supporting sustained energy expenditure. The question remains whether in order to prevent weight gain without previous weight loss, thus in energy balance, a fat free mass sparing effect can be observed as a consequence of a protein rich diet.

\section{METHODS}

Subjects were recruited by means of an advertisement in local newspapers and on notice boards at Maastricht University. Twenty-five subjects (11 men, 14 women) started, 8 subjects ( 5 men and 3 women; 4 subjects in each group) dropped out due to several reasons, such as personal and an inability to fulfill the schedule. One subject of the control group had excessive protein intake at baseline $(216 \mathrm{~g}$ at baseline and $89 \mathrm{~g}$ during the intervention) and was removed from the analysis. All subjects were in good health, non-smokers, at most moderate alcohol users, had a stable body weight and did not use prescription medication.

This study was conducted according to the guidelines laid down in the Declaration of Helsinki and all procedures involving human subjects were approved by the Medical Ethics committee of the University and Academic Hospital of Maastricht. Written informed consent was obtained from all subjects.

The study had a parallel design and consisted of a dietary intervention of 3 months. Subjects were counseled to consume eucaloric diets to sustain body weight with $2 \mathrm{MJ}$ milk-protein or carbohydrate-fat supplements as an exchange of a $2 \mathrm{MJ}$ part of their habitual diet. The protein supplements contained in total $52 \mathrm{~g}$ of milk-protein (Modifast, Novartis Nutrition, Breda, The Netherlands). The control group received carbohydrate-fat supplements consisting of a limonade (Karvan Cevitam, Koninklijke de Ruijter, Zeist, The Netherlands) and of olive oil. All subjects were instructed to consume daily at least $200 \mathrm{~g}$ of fruit and $300 \mathrm{~g}$ of vegetables.

We used 24-hour urine nitrogen to quantify protein intakes at baseline and during the intervention at 1.5 and 3 months, as a compliance marker for the increase in protein as a result of the $2 \mathrm{MJ}$ exchange by the protein supplements. Samples were collected with $10 \mathrm{~mL} \mathrm{H}_{2} \mathrm{SO}_{4}$ to prevent nitrogen loss through evaporation, stored frozen at $-20^{\circ} \mathrm{C}$, and later analyzed for urinary nitrogen with a nitrogen analyzer (CHN-O-Rapid; 
Heraeus, Hanau, Germany). We did not use dietary record methods, as they are prone to misreporting (12).

To monitor body weight stability, as a compliance marker for the maintenance of energy intake, subjects were instructed to measure their body weight daily at home. At the University, body weight was measured 2-weekly using a digital balance (ChyoMW-150K, Chyo, Japan; weighing accuracy $0.02 \mathrm{~kg}$ ) with subjects in underwear. Body composition was assessed in the fasting state within the same morning with the 4-compartment model of Lohman; fat percentage $(\% \mathrm{FM})=(274.7 / \mathrm{Db}-71.4 \mathrm{TBW} / \mathrm{BM}$ $+114.6 \mathrm{BMC} / \mathrm{BM}$ - 205.03). Measurements were whole-body density (Db) with the underwater-weighing technique with residual lung volume measured simultaneously with the helium-dilution technique, total body water (TBW) with the deuteriumdilution technique (13), and total bone mineral content (BMC) with whole-body DXA (Lunar Corp., Madison, WI). Measuring whole-body density, total body water and total bone mineral content separately increases the accuracy of fat free mass and fat mass measurements and is therefore more suitable to determine changes in fat free mass and fat mass, especially if subjects sustain their body weight. The day before the measurements, subjects were asked to refrain from alcohol, refrain from indulgement in strenuous exercise and to refrain from eating and drinking after 11:00 PM. At the morning of the tests, we asked subjects if they had been compliant to these requests. Furthermore, subjects were instructed to maintain their baseline body weight and customary level of physical activity for the duration of the study.

To determine physical activity the validated Baecke-questionnaire was used (14).

To determine whether attitudes towards food intake changed during the experiment, a validated Dutch translation of the Three Factor Eating Questionnaire (TFEQ) was used (15).

Systolic and diastolic blood pressures were recorded using an automatic blood pressure monitor with subjects in sitting position (OSZ 5 easy; Spreidel \& Keller $\mathrm{GmBH}$ and Co. KG, Jungingen, Germany).

Fasting plasma samples of glucose, insulin, FFA, TAG, HDL, LDL and total cholesterol were collected in EDTA-tubes, centrifuged at $1500^{*} \mathrm{~g}$ for $10 \mathrm{~min}$ at $4^{\circ} \mathrm{C}$, frozen in nitrogen and stored at $-80^{\circ} \mathrm{C}$ until analysis. The Statistical Package for the Social Sciences (SPSS) version 16.0.2 for Macintosh OS X was used to analyze group comparisons with ANOVA, changes over time with 2-tailed paired Student T-tests, and relations between protein intake and body composition with linear regressions.

\section{RESULTS AND DISCUSSION}

Physical activity, body weight (BM) and BMI did not change significantly over the 3months of intervention (Table 5.1). So, subjects were in energy balance and diets were eucaloric during the intervention. Protein intake determined according to 24-hour urinary nitrogen significantly increased in the protein group $(11 \pm 14 \mathrm{~g}$ or $0.1 \pm 0.2 \mathrm{~g} / \mathrm{kgBM}, \mathrm{p}<0.05)$, which resulted into significantly different protein intake between both groups during the intervention $(80 \pm 21$ vs. $59 \pm 11 \mathrm{~g}, \mathrm{p}<0.05 ; 1.2 \pm 0.2 \mathrm{vs}$. $0.9 \pm 0.1 \mathrm{~g} / \mathrm{kgBM}, \mathrm{p}<0.05)$. Baseline protein intake did not differ between groups. As a result of the increase in protein intake fat free mass increased, and fat mass and fat percentage decreased in the protein group $(0.9 \pm 0.6 \mathrm{~kg}, \mathrm{p}<0.01 ;-0.6 \pm 0.8 \mathrm{~kg}, \mathrm{p}<0.05$; $-1.0 \pm 1.1 \%, \mathrm{p}<0.05)$, which resulted in a significant change in fat percentage over time 
between both groups $(-1.0 \pm 1.1$ vs. $0.3 \pm 0.7 \%, \mathrm{p}<0.05)$. Protein intake during the intervention of the protein group explained $51 \%$ of the variation in fat percentage after the intervention $(\mathrm{r}=-0.712, \mathrm{p}<0.01)$. Furthermore, protein intake was related to fat mass and fat free mass $(\mathrm{r}=-0.617, \mathrm{p}<0.05 ; \mathrm{r}=0.716, \mathrm{p}<0.01)$.

As muscle protein synthesis is greatly influenced by systemic amino acid availability (16) nitrogen retention results into net muscle protein synthesis. Nitrogen retention is an acute response to a protein-rich meal (17). Consumption of a proteinrich diet in energy balance continued to achieve nitrogen retention after 1 week to 50 days (18). The positive nitrogen balance of $1.6 \mathrm{~g}(4.4 \%$ of daily nitrogen intake of $36 \mathrm{~g})$ did not show a significant trend to reach a new nitrogen balance (18). Nitrogen excretion is reflecting precisely any increase in amino acid oxidation and subsequent nitrogen elimination. So, assuming that all nitrogen retention is used to build up fat free mass, we can calculate a predicted increase in fat free mass according to daily nitrogen retention of $4.4 \%$ and the 24-hour urine nitrogen excretion of $89 \%$ measured in the study of Odoye et al. (18). Average 24-hour urine nitrogen during the intervention of 3 months was $12.8 \mathrm{~g}$ (80 g protein/6.25) in the protein group, thus calculated daily positive nitrogen balance was $0.56 \mathrm{~g}(4.4 \%$ of $12.8 \mathrm{~g})$. Assuming the factor of $34 \mathrm{~g}$ nitrogen per $\mathrm{kg}$ fat free mass, $0.016 \mathrm{~kg}$ fat free mass would be built up each day resulting in a total predicted increase of $1.5 \mathrm{~kg}$ fat free mass over 90 days. Taking together, an amount of $1.2 \mathrm{~g} / \mathrm{kgBM}$ in energy balance is sufficient to reach a prolonged positive whole-body nitrogen balance leading to an increase in fat free mass of $0.9 \mathrm{~kg}$ or $2 \%$ of initial $52.1 \mathrm{~kg}$ fat free mass over 90 days at the cost of fat mass. Of all macronutrients, proteins have shown to be the most thermogenic $(4,5)$, to increase 24-hour energy expenditure (19), and thereby promote a negative energy balance. The low energy efficiency of proteins even resulted in a limited body weight-gain during overfeeding $(20,21)$. The elevated thermogenesis may be reached by increased oxygen consumption $(22,23)$ mediated by the high ATP costs of postprandial protein synthesis (24-26). Infusion of amino acids stimulates muscle protein synthesis and increase resting energy expenditure (27). Synthesis and breakdown of muscle protein contribute to the energy expenditure of resting muscle (24). Thus, increase in total fat free mass leads to an increase in total energy expenditure. This elevated energy expenditure is mainly derived from fat oxidation, as it is the preferred substrate of muscle during resting conditions (28). The elevated thermogenesis explains the decrease in fat mass during energy balance co-occurring with the build up of fat free mass in weight stable subjects.

Previously, only resistance exercise changed the body composition in energy balance into a more favorable composition (29). Total activity index of the Baeckequestionnaire and its sub-scores sport, leisure time, and work did not change. So, increased protein intake supported by a moderately active lifestyle without increase in physical activity is also beneficial for a more favorable body composition.

Protein rich diets showed favorable effects on glycemic control (30-33). These improved metabolic parameters are possibly more related to the decrease in body weight than the elevation in protein. In this study, fasting glucose and insulin did not change after the 3 months of elevation in protein intake. 
Table 5.1. Subject characteristics

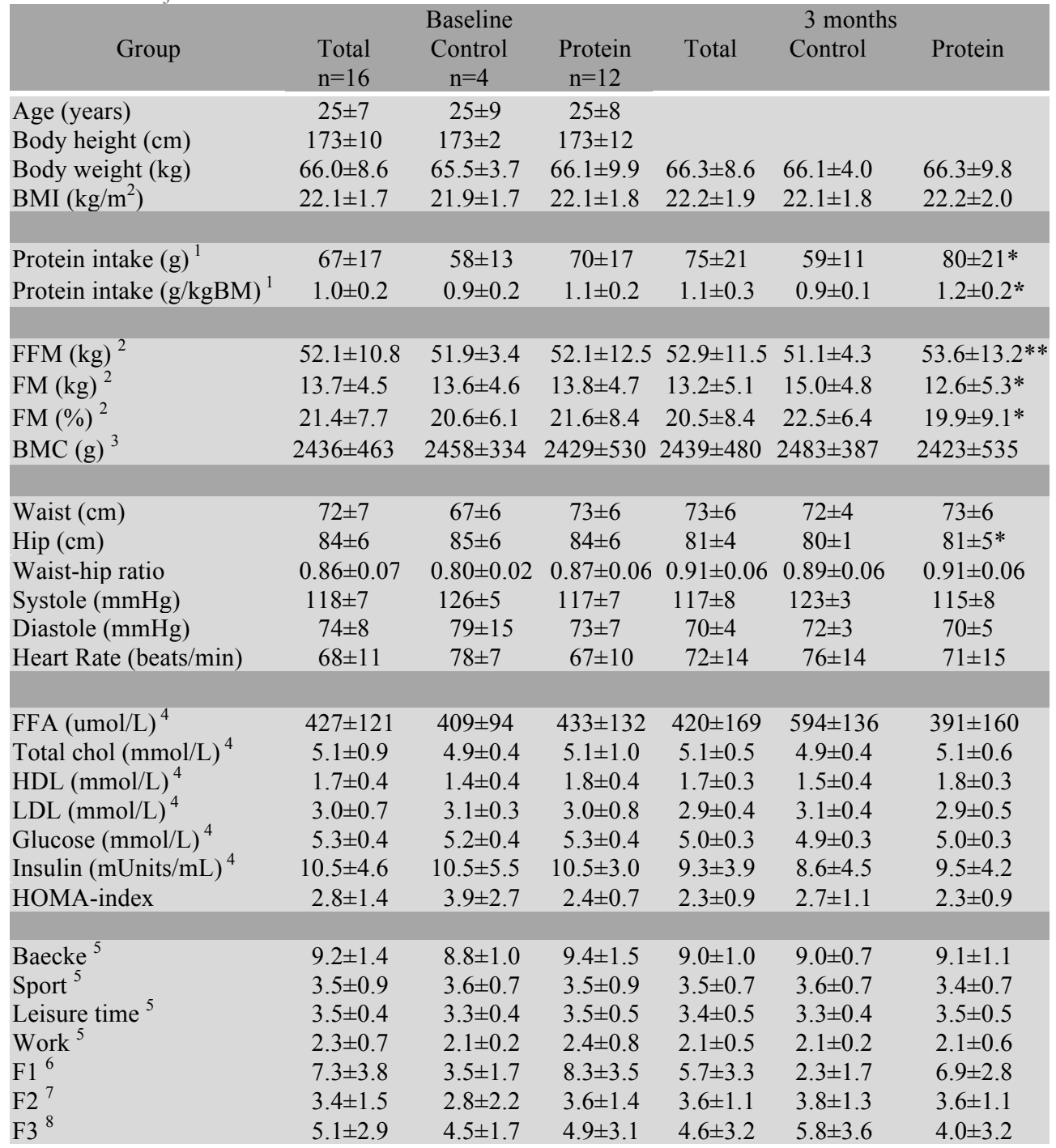

Mean valuess \pm standard deviations of the protein and control diet groups.

$* \mathrm{p}<0.05, * * \mathrm{p}<0.01$; changes over time compared to baseline within groups.

${ }^{1}$ Protein intake based on 24-hour urinary nitrogen content; the 3-month value is the protein intake during the intervention; average of 1.5 and 3 months.

${ }^{2}$ Body composition of the 4-compartment model of Lohman; \%FM $=(274.7 / \mathrm{Db}-71.4 \mathrm{TBW} / \mathrm{BM}$ $+114.6 \mathrm{BMC} / \mathrm{BM}-205.03)$.

${ }^{3}$ Total bone mineral content (BMC) with whole-body DXA.

${ }^{4}$ Plasma concentrations after overnight fasting, $n=15$ at 3 months.

${ }^{5}$ The Baecke total activity index and its activity sub-scores of sport, leisure time and work.

${ }^{6} \mathrm{~A}$ measure of cognitive restraint of the three-factor eating questionnaire (TFEQ); minimum score 0 , maximum score 21; cut-off point fort he Dutch population 9. Values greater than 9 indicate cognitive restraint eating.

${ }^{7}$ A measure of disinhibition or emotional eating of the TFEQ; minimum score 0 , maximum score 14.

${ }^{8} \mathrm{~A}$ general feeling of hunger of the TFEQ; minimum score 0 , maximum score 14 . 
Previously, there was concern about the interference of protein rich diets with bone balance. It was suggested that the acid load would be partially buffered by bone, which could result in bone resorption and hypercalciuria, and furthermore result in a negative calcium balance (34). Increased urinary calcium excretion however, stimulates increased intestinal calcium absorption without contribution from bone resorption (35), and thus does not result in negative protein-induced effects on calcium balance (36), bone-turnover markers or bone turnover (35). Total bone mineral content did not change over the 3 months. Bone mineral content after the intervention was positively related to protein intake during the intervention $(\mathrm{r}=0.783, \mathrm{p}<0.01)$. Furthermore, a review of large clinical prospective epidemiological studies concluded that highprotein intake is associated with increased bone mineral content (37). Even during weight loss, protein intake positively effected calcium balance and consequently preserved bone mineral content (38).

In conclusion, increased protein intake of 3 months in energy balance results in a more favorable body composition, i.e. an increased fat free mass at the cost of fat mass, without the trigger of energy restriction or increase in physical activity.

\section{ACKNOWLEDGEMENTS}

We gratefully acknowledge Edith van den Hooven for her assistance. The study was supported by Top Institute Food and Nutrition (TIFN, Wageningen, Netherlands. 


\section{REFERENCES}

1. Soenen S, Westerterp-Plantenga MS. Proteins and satiety: implications for weight management. Curr Opin Clin Nutr Metab Care 2008;11:747-51.

2. Weigle DS, Breen PA, Matthys CC, et al. A high-protein diet induces sustained reductions in appetite, ad libitum caloric intake, and body weight despite compensatory changes in diurnal plasma leptin and ghrelin concentrations. Am J Clin Nutr 2005;82:41-8.

3. Westerterp-Plantenga MS, Lejeune MP, Nijs I, van Ooijen M, Kovacs EM. High protein intake sustains weight maintenance after body-weight loss in humans. Int J Obes Relat Metab Disord 2004;28:57-64.

4. Westerterp-Plantenga MS, Rolland V, Wilson SA, Westerterp KR. Satiety related to $24 \mathrm{~h}$ diet induced thermogenesis during high protein/carbohydrate vs high fat diets measured in a respiration chamber. Eur J Clin Nutr 1999;53:495-502.

5. Nair KS, Halliday D, Garrow JS. Thermic response to isoenergetic protein, carbohydrate or fat meals in lean and obese subjects. Clin Sci (Lond) 1983;65:307-12.

6. Krieger JW, Sitren HS, Daniels MJ, Langkamp-Henken B. Effects of variation in protein and carbohydrate intake on body mass and composition during energy restriction: a meta-regression 1. Am J Clin Nutr 2006;83:260-74.

7. Lejeune MP, Kovacs EM, Westerterp-Plantenga MS. Additional protein intake limits weight regain after weight loss in humans. Br J Nutr 2005;93:281-9.

8. Layman DK, Boileau RA, Erickson DJ, et al. A reduced ratio of dietary carbohydrate to protein improves body composition and blood lipid profiles during weight loss in adult women. J Nutr 2003;133:411-7.

9. Skov AR, Toubro S, Ronn B, Holm L, Astrup A. Randomized trial on protein vs carbohydrate in ad libitum fat reduced diet for the treatment of obesity. Int J Obes Relat Metab Disord 1999;23:528-36.

10. Piatti PM, Monti F, Fermo I, et al. Hypocaloric high-protein diet improves glucose oxidation and spares lean body mass: comparison to hypocaloric high-carbohydrate diet. Metabolism 1994;43:1481-7.

11. Deibert P, Konig D, Schmidt-Trucksaess A, et al. Weight loss without losing muscle mass in preobese and obese subjects induced by a high-soy-protein diet. Int J Obes Relat Metab Disord 2004;28:1349-52.

12. Westerterp KR, Goris AH. Validity of the assessment of dietary intake: problems of misreporting. Curr Opin Clin Nutr Metab Care 2002;5:489-93.

13. Westerterp KR, Wouters L, van Marken Lichtenbelt WD. The Maastricht protocol for the measurement of body composition and energy expenditure with labeled water. Obes Res 1995;3 Suppl 1:49-57.

14. Philippaerts RM, Westerterp KR, Lefevre J. Doubly labelled water validation of three physical activity questionnaires. Int J Sports Med 1999;20:284-9.

15. Stunkard AJ, Messick S. The three-factor eating questionnaire to measure dietary restraint, disinhibition and hunger. J Psychosom Res 1985;29:71-83.

16. Paddon-Jones D, Sheffield-Moore M, Zhang XJ, et al. Amino acid ingestion improves muscle protein synthesis in the young and elderly. Am J Physiol Endocrinol Metab 2004;286:E321-8.

17. Pannemans DL, Wagenmakers AJ, Westerterp KR, Schaafsma G, Halliday D. Effect of protein source and quantity on protein metabolism in elderly women. Am J Clin Nutr 1998;68:1228-35.

18. Oddoye EA, Margen S. Nitrogen balance studies in humans: long-term effect of high nitrogen intake on nitrogen accretion. J Nutr 1979;109:363-77.

19. Dauncey MJ, Bingham SA. Dependence of $24 \mathrm{~h}$ energy expenditure in man on the composition of the nutrient intake. Br J Nutr 1983;50:1-13.

20. Dulloo AG, Jacquet J. Low-protein overfeeding: a tool to unmask susceptibility to obesity in humans. Int J Obes Relat Metab Disord 1999;23:1118-21.

21. Stock MJ. Gluttony and thermogenesis revisited. Int J Obes Relat Metab Disord 1999;23:110517. 
22. Halton TL, Hu FB. The effects of high-protein diets on thermogenesis, satiety and weight loss: a critical review. J Am Coll Nutr 2004;23:373-85.

23. Westerterp-Plantenga MS. The significance of protein in food intake and body weight regulation. Curr Opin Clin Nutr Metab Care 2003;6:635-8.

24. Wolfe RR. The underappreciated role of muscle in health and disease. Am J Clin Nutr 2006;84:475-82.

25. Tessari P, Kiwanuka E, Zanetti M, Barazzoni R. Postprandial body protein synthesis and amino acid catabolism measured with leucine and phenylalanine-tyrosine tracers. Am J Physiol Endocrinol Metab 2003;284:E1037-42.

26. van Milgen J. Modeling biochemical aspects of energy metabolism in mammals. J Nutr 2002;132:3195-202.

27. Giordano M, Castellino P. Correlation between amino acid induced changes in energy expenditure and protein metabolism in humans. Nutrition 1997;13:309-12.

28. Rasmussen BB, Wolfe RR. Regulation of fatty acid oxidation in skeletal muscle. Annu Rev Nutr 1999;19:463-84.

29. Phillips SM. Physiologic and molecular bases of muscle hypertrophy and atrophy: impact of resistance exercise on human skeletal muscle (protein and exercise dose effects). Appl Physiol Nutr Metab 2009;34:403-10.

30. Promintzer M, Krebs M. Effects of dietary protein on glucose homeostasis. Curr Opin Clin Nutr Metab Care 2006;9:463-8.

31. Manco M, Mingrone G. Effects of weight loss and calorie restriction on carbohydrate metabolism. Curr Opin Clin Nutr Metab Care 2005;8:431-9.

32. Gannon MC, Nuttall FQ. Effect of a high-protein, low-carbohydrate diet on blood glucose control in people with type 2 diabetes. Diabetes 2004;53:2375-82.

33. Gannon MC, Nuttall FQ, Saeed A, Jordan K, Hoover H. An increase in dietary protein improves the blood glucose response in persons with type 2 diabetes. Am J Clin Nutr 2003;78:734-41.

34. Hegsted M, Linkswiler HM. Long-term effects of level of protein intake on calcium metabolism in young adult women. J Nutr 1981;111:244-51.

35. Kerstetter JE, O'Brien KO, Caseria DM, Wall DE, Insogna KL. The impact of dietary protein on calcium absorption and kinetic measures of bone turnover in women. J Clin Endocrinol Metab 2005;90:26-31.

36. Pannemans DL, Schaafsma G, Westerterp KR. Calcium excretion, apparent calcium absorption and calcium balance in young and elderly subjects: influence of protein intake. Br J Nutr 1997;77:721-9.

37. Bonjour JP. Dietary protein: an essential nutrient for bone health. J Am Coll Nutr 2005;24:526S$36 \mathrm{~S}$.

38. Westerterp KR. Weight loss and bone mineral content. Obes Res 2002;10:559. 



\section{PROTEIN INTAKE INDUCED INCREASE}

\section{IN EXERCISE STIMULATED FAT OXIDATION \\ IN ENERGY BALANCE}

Stijn Soenen, Guy Plasqui, Astrid J Smeets

AND MARgRiet S WeSTERTERP-Plantenga

SUBMITTED FOR PUBLICATION 


\section{ABSTRACT}

\section{Background}

Protein-rich weight-loss diets spare fat free mass at the cost of fat mass.

\section{Objective}

The objective was to examine if there is a change in stimulated fat oxidation related to protein intake in energy balance.

\section{Design}

Maximal fat oxidation ( $\mathrm{Fat}_{\mathrm{max}}$ ) was assessed during a graded bicycle test, before and after a 3-month dietary-intervention. Subjects (BMI $22 \pm 2 \mathrm{~kg} / \mathrm{m}^{2}$, age $25 \pm 8 \mathrm{y}$ ) were fed in energy balance by exchanging $2 \mathrm{MJ}$ of habitual energy intake with $2 \mathrm{MJ}$ supplements of protein (protein group) or carbohydrate and fat (control group). Protein intake was determined according to 24-hour urine nitrogen, and body-composition according to a 4-compartment model.

\section{Results}

Subjects were in energy balance without changing physical activity. The protein group $(\mathrm{n}=12)$ increased protein intake $(11 \pm 14 \mathrm{~g}, \mathrm{p}<0.05)$ and had significantly higher daily protein intake vs. control $(n=4)(80 \pm 21$ vs. $59 \pm 11 \mathrm{~g}, \mathrm{p}<0.05)$. Fat max $_{\text {increased }}$ significantly in the protein group $(0.08 \pm 0.08 \mathrm{~g} / \mathrm{min}, \mathrm{p}<0.01)$, fat free mass increased independent of change in body weight $(\mathrm{p}<0.01)$, and fat mass and fat percentage decreased $(\mathrm{p}<0.05)$. Change in $\mathrm{Fat}_{\max }$ was a function of change in protein intake $(\mathrm{r}=0.623, \mathrm{p}<0.05)$, and not of changes in body composition or $\mathrm{VO}_{2 \max }$.

\section{Conclusion}

Increased stimulated fat oxidation was related to increased protein intake.

\section{Keywords}

protein intake, fat oxidation, fat mass, fat free mass, fat percentage 


\section{INTRODUCTION}

Obesity is a condition in which fat mass and fat percentage are increased (1) and levels of fat oxidation are suggested to be disturbed (2). Fat and carbohydrate oxidation are mainly influenced by exercise intensity (3). With increasing exercise intensity, fat oxidation first increases to its maximal fat oxidation rate (Fat $\mathrm{max}_{\max }$ ) from low- to moderate-exercise intensities and then decreases from moderate- to high-exercise intensities (3). The daily majority of energy demand is at rest or during moderate exercise intensity. During these conditions, fat oxidation is the main source of energy production for the body (4). So, moderate-exercise intensity yields the most grams of fat used for oxidation, and could therefore play a role in the maintenance or reduction of fat mass. The desired goal for treatment and reduction of development of obesity is to decrease fat mass whilst preserving or increasing fat free mass. Increased protein intake has shown to result in greater loss of fat mass and less loss of fat free mass during energy restriction, and lower regain of fat mass and greater regain of fat free mass during weight regain after weight loss (5-7). The resulted higher ratio of fat free mass to fat mass plays an important role in the maintenance of energy balance (8) and the preservation of metabolic and overall health $(9,10)$. Since elevated protein intake results in a more favorable body composition during weight loss and weight maintenance thereafter, and since fat mass is mainly reduced during moderate-exercise intensity, the question remains whether these characteristics hold when subjects are in conditions of energy balance. Therefore, the aim of this study was to investigate whether a change in dietary protein might change stimulated fat oxidation during exercise in subjects with constant body weight over time.

\section{METHODS}

\section{Subjects}

Subjects were recruited by means of an advertisement in local newspapers and on notice boards at Maastricht University. Subjects who were willing to participate in the study were subsequently screened, by means of a detailed medical history and a physical examination. All subjects were in good health, non-smokers, at most moderate alcohol users, had a stable body weight $(<2 \mathrm{k}$ g change over at least the last two months) and did not use prescription medication. All subjects gave a written informed consent. The Medical Ethics committee of the University and Academic Hospital of Maastricht approved the study. Twenty-five subjects started in the study, 11 men and 14 women. Eight subjects (5 men and 3 women, 4 subjects in each group) dropped out due to several reasons, such as personal and an inability to fulfill the schedule with visits to the university. One subject of the control group had excessive protein intake at baseline (216 $\mathrm{g}$ at baseline and $89 \mathrm{~g}$ during the intervention), and was removed from the analysis. Subject characteristics $(n=16 ; 12$ in the protein group and 4 in the control group) are given in Table 6.1.

\section{Study design}

The study had a parallel design and consisted of a dietary intervention period of 3 months. A test day that included measurement of substrate oxidation during a graded bicycle test to exhaustion, measurements of body composition, blood sampling and 
completing questionnaires took place at baseline and after 3 months of intervention. Subjects were familiarized with the equipment and the procedures before the start of all measurements. Measurements were performed in the morning after an overnight fast. The bicycle-ergometer test started at the same time in the morning to avoid circadian variance. The day before both test days, subjects were asked to refrain from alcohol, refrain from indulgement in strenuous exercise and to refrain from eating and drinking after 11:00 PM. Subjects were instructed to maintain their baseline body weight and to maintain their customary level of physical activity during the entire duration of the study.

\section{Dietary intervention}

Subjects were fed in energy balance with eucaloric diets to sustain body weight by exchanging $2 \mathrm{MJ}$ of their habitual energy intake with $2 \mathrm{MJ}$ of supplements. The protein group received protein supplements consisting of milk proteins. These protein supplements were rich in essential micronutrients and were supplied in three sachets daily containing in total $52 \mathrm{~g}$ of milk protein, dissolved in water to obtain a milk shake, pudding, soup or muesli (Modifast, Novartis Nutrition, Breda, The Netherlands). The control group received carbohydrate-fat supplements consisting of a limonade (Karvan Cevitam, Koninklijke de Ruijter, Zeist, The Netherlands) and of olive oil. All subjects were instructed to consume daily at least $200 \mathrm{~g}$ of fruit and $300 \mathrm{~g}$ of vegetables.

To asses dietary protein intake, subjects completed three 24-hour urine collections at baseline and in week 6 and 12. Samples were samples were collected with $10 \mathrm{~mL}$ $\mathrm{H}_{2} \mathrm{SO}_{4}$ to prevent nitrogen loss through evaporation, stored frozen at $-20^{\circ} \mathrm{C}$, and later analyzed for urinary nitrogen with a nitrogen analyzer (CHN-O-Rapid; Heraeus, Hanau, Germany).

\section{Anthropometry}

To monitor body weight stability, subjects were instructed to measure their body weight daily at home. At the University, body weight was measured 2-weekly using a digital balance (Chyo-MW-150K, Chyo, Japan; weighing accuracy $0.02 \mathrm{~kg}$ ) with subjects in underwear, in the fasted state and after voiding their bladder. If body weight fluctuated by $>2 \mathrm{~kg}$ from baseline, subjects were instructed to adjust their energy intake to encourage a return to and maintenance of baseline body weight. Height was measured at baseline to the nearest $0.1 \mathrm{~cm}$ using a wall-mounted stadiometer (Seca, model 220, Hamburg, Germany). Body mass index (BMI) was calculated by dividing body weight by height squared $\left(\mathrm{kg} / \mathrm{m}^{2}\right)$.

\section{Body composition}

Body composition was assessed in the fasted state with the 4-compartment model of Lohman (11). The model was used to calculate fat percentage $(\% \mathrm{FM})$ from the independently determined whole-body density $(\mathrm{Db})$, total body water (TBW) and total bone mineral content (BMC). Measuring whole-body density, total body water and total bone mineral content separately increases the accuracy of fat free mass and fat mass at baseline and after the intervention and is therefore more suitable to determine changes in fat free mass and fat mass, especially if subjects sustain their body weight. All measurements were completed within the same morning. The used equation of 
Lohman was $\% \mathrm{FM}=(2.747 / \mathrm{Db}-0.714 \times \mathrm{TBW} / \mathrm{BM}+1.146 \times \mathrm{BMC} / \mathrm{BM}-2.0503) \mathrm{x}$ 100 (11).

Whole-body density was measured with the underwater weighing technique. Body mass in air and underwater were determined on a digital balance, accurate to $0.01 \mathrm{~kg}$ (Sauer type E1200). Residual lung volume was measured simultaneously with the helium dilution technique using a spirometer (Volugraph 2000, Mijnhardt, The Netherlands).

Total body water was measured using the deuterium-dilution technique according to the Maastricht protocol (12). In the evening before the test day, subjects collected a background urine sample and then ingested a dose of deuterium-enriched water, after which they refrained from consuming fluid and food. The following morning, a urine sample from the second voiding was collected between 08.00 and 10.00 AM. The concentration of deuterium in the urine samples was measured using an isotope ratio mass spectrometer (Micromass Optima, Manchester, UK). The dilution of the deuterium isotope $\left({ }^{2} \mathrm{H}_{2} \mathrm{O}\right)$ is a measure for total body water. Total body water was obtained by dividing the measured deuterium-dilution space by 1.04 to correct for exchange of the ${ }^{2} \mathrm{H}$ label with non-aqueous hydrogen of body solids (13).

Total bone mineral content was measured using dual-energy X-ray absorptiometry (DXA; Lunar Corp., Madison, WI) with a resolution of 4.8 x $9.6 \mathrm{~mm}$ (whole-body). Bone content and density were calculated by Lunar software (version 1.3z). The subjects wore loose metal free clothing and remained in a supine position while scanning was completed. The results were compared with the Germany Total Body White Reference Population provided by the manufacturer.

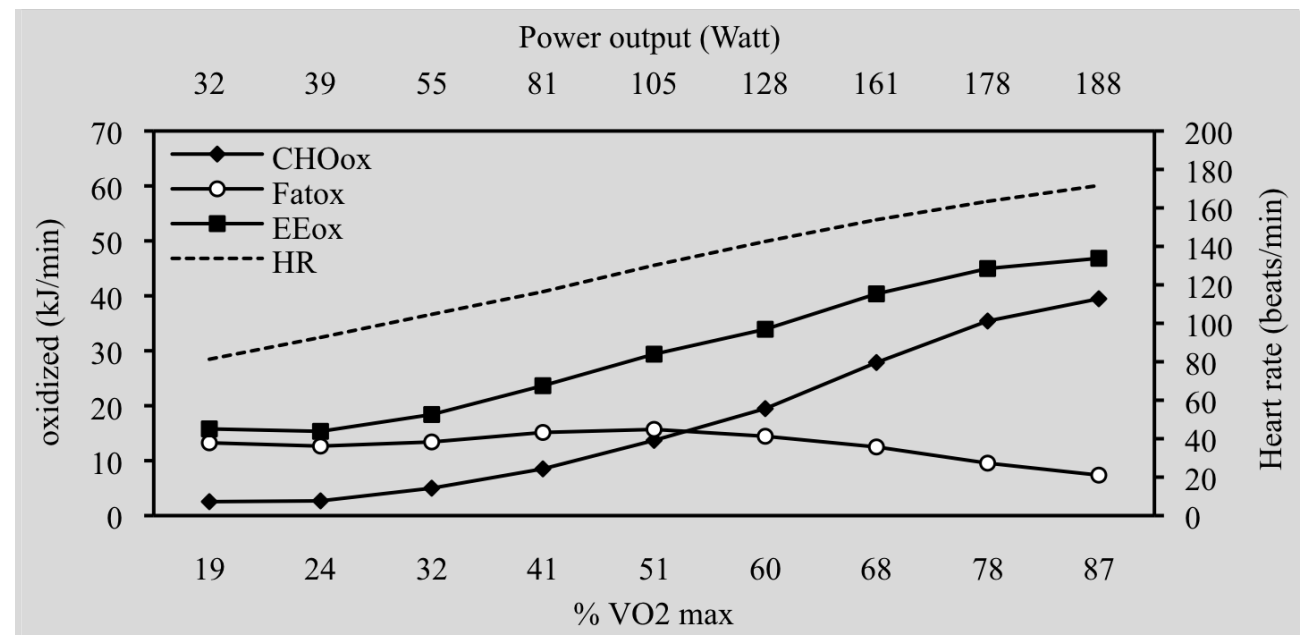

Figure 6.1. Fat oxidation in function of $\mathrm{VO}_{2 \max }$ and power output during a graded bicycle test to exhaustion

CHOox is the amount of carbohydrate oxidized in $\mathrm{kJ} / \mathrm{min}$

Fatox is the amount of fat oxidized in $\mathrm{kJ} / \mathrm{min}$

EEox is the amount of total energy expenditure in $\mathrm{kJ} / \mathrm{min}$

$\mathrm{HR}$ is heart rate in beats/min 


\section{Substrate oxidation during the cycle-ergometer test}

Subjects performed a graded exercise test to exhaustion on an electromagnetically braked bicycle ergometer (Excalibur, Lode, Groningen, The Netherlands). Simultaneous indirect calorimetric breath-by-breath measurements enabled to measure fat oxidation rate over a wide range of intensities. Fat oxidation rate was plotted against exercise intensity, expressed as $\% \mathrm{VO}_{2 \max }$, power output and heart rate, constructing a fat oxidation curve to accurately determine maximum fat oxidation $\left(\mathrm{Fat}_{\max }\right)$. The cycle ergometer protocol has been validated to determine the exercise intensity that elicits $\mathrm{Fat}_{\max }$ (14). Moreover, it has been shown that the early stages of this type of protocol do not influence the exercise intensity at Fat $\max _{\max }(14)$.

Workload of the cycle-ergometer test was calculated for each subject to standardize the cycling protocol between subjects. Subjects started cycling at a workload of $0.5 \mathrm{~W} / \mathrm{kg}$ fat free mass. Workload was increased by $0.5 \mathrm{~W} / \mathrm{kg}$ fat free mass every 3 minutes until exhaustion. Maximal workload was calculated as the last completed stage plus the fraction of time spent in the final non-completed stage multiplied by the workload increment.

Indirect calorimetric measurements were performed using an Omnical IV gas analysis system. The gas analyzers were calibrated with a $\% \mathrm{CO}_{2}-\% \mathrm{~N}_{2}$ gas mixture. Average values for oxygen uptake $\left(\mathrm{VO}_{2}\right)$ and carbon dioxide production $\left(\mathrm{VCO}_{2}\right)$ were calculated over the last 2 minutes of each 3 minutes stage, during which the respiratory quotient $\left(\mathrm{RQ}=\mathrm{VCO}_{2} / \mathrm{VO}_{2}\right.$ ) was $<1 . \mathrm{VO}_{2 \max }$ was calculated as the average oxygen uptake of the 3 highest sequent oxygen uptakes during the last 60 seconds of the cycle test. Stages of 3 minutes can be used to accurately determine $\mathrm{VO}_{2 \max }(15)$. Fat and carbohydrate oxidation and energy expenditure were calculated using stoichiometric equations and appropriate energy equivalents, with the assumption that the urinary nitrogen excretion rate was negligible during the cycle test.

Heart rate was recorded continuously during the test by using a radio telemetry heart rate monitor (Polar S610, Polar Electro Ltd., Oy, Finland).

\section{Physical activity}

To determine physical activity the validated (16) Baecke-questionnaire was used. The Baecke-questionnaire consists of three components: work activity, sports activity and leisure time activity.

\section{Blood samples}

Fasting venous blood samples were taken to determine concentrations of plasma FFA and TAG. The blood samples were collected in tubes containing EDTA to prevent clotting. Plasma was obtained by centrifugation $\left(1500^{*} \mathrm{~g}\right.$ for $10 \mathrm{~min}$ at $\left.4^{\circ} \mathrm{C}\right)$, frozen in liquid nitrogen and stored at $-80^{\circ} \mathrm{C}$ until analysis. FFA concentrations were measured using the Wako NEFA C-kit (Wako Chemicals, Neuss, Germany).

\section{Statistical analysis}

Groups were compared by ANOVA. Changes over time within groups were compared by 2 -tailed paired Student T-tests. Regression analyses were used to analyze the relation between fat oxidation and body composition or protein intake. All analyses 
were performed with the Statistical Package for the Social Sciences (SPSS) version 16.0.2 for Macintosh OS X. Differences were regarded as significant if $\mathrm{p}<0.05$.

\section{RESULTS}

Body weight (BM) and BMI did not change significantly over the intervention period (Table 6.1). Protein intake determined according to 24-hour urinary nitrogen was significantly different between the protein and control group during the 3 months of intervention ( $80 \pm 21$ vs. $59 \pm 11 \mathrm{~g}, \mathrm{p}<0.05$; or $1.2 \pm 0.2$ vs. $0.9 \pm 0.1 \mathrm{~g} / \mathrm{kgBM}, \mathrm{p}<0.05$ ). The protein group significantly increased in protein intake $(11 \pm 14 \mathrm{~g}, \mathrm{p}<0.05$; and $0.1 \pm 0.2 \mathrm{~g} / \mathrm{kgBM}, \mathrm{p}<0.05)$. Baseline protein intake did not differ between groups.

Table 6.1. Subject characteristics

\begin{tabular}{|c|c|c|c|c|c|c|}
\hline Group & $\begin{array}{l}\text { Total } \\
\mathrm{n}=16\end{array}$ & $\begin{array}{c}\text { Baseline } \\
\text { Control } \\
n=4\end{array}$ & $\begin{array}{c}\text { Protein } \\
n=12\end{array}$ & Total & $\begin{array}{l}3 \text { months } \\
\text { Control }\end{array}$ & Protein \\
\hline Age (years) & $25 \pm 7$ & $25 \pm 9$ & $25 \pm 8$ & & & \\
\hline Body height (cm) & $173 \pm 10$ & $173 \pm 2$ & $173 \pm 12$ & & & \\
\hline Body weight (kg) & $66.0 \pm 8.6$ & $65.5 \pm 3.7$ & $66.1 \pm 9.9$ & $66.3 \pm 8.6$ & $66.1 \pm 4.0$ & $66.3 \pm 9.8$ \\
\hline $\operatorname{BMI}\left(\mathrm{kg} / \mathrm{m}^{2}\right)$ & $22.1 \pm 1.7$ & $21.9 \pm 1.7$ & $22.1 \pm 1.8$ & $22.2 \pm 1.9$ & $22.1 \pm 1.8$ & $22.2 \pm 2.0$ \\
\hline FFM $(\mathrm{kg})^{1}$ & $52.1 \pm 10.8$ & $51.9 \pm 3.4$ & $52.1 \pm 12.5$ & $52.9 \pm 11.5$ & $51.1 \pm 4.3$ & $53.6 \pm 13.2 * *$ \\
\hline $\mathrm{FM}(\mathrm{kg})^{1}$ & $13.7 \pm 4.5$ & $13.6 \pm 4.6$ & $13.8 \pm 4.7$ & $13.2 \pm 5.1$ & $15.0 \pm 4.8$ & $12.6 \pm 5.3^{*}$ \\
\hline $\mathrm{FM}(\%)^{1}$ & $21.4 \pm 7.7$ & $20.6 \pm 6.1$ & $21.6 \pm 8.4$ & $20.5 \pm 8.4$ & $22.5 \pm 6.4$ & $19.9 \pm 9.1^{*}$ \\
\hline FFA $(u m o l / L)^{2}$ & $427 \pm 121$ & $409 \pm 94$ & $433 \pm 132$ & $420 \pm 169$ & $594 \pm 136$ & $391 \pm 160$ \\
\hline Protein intake $(\mathrm{g})^{3}$ & $67 \pm 17$ & $58 \pm 13$ & $70 \pm 17$ & $75 \pm 21$ & $59 \pm 11$ & $80 \pm 21 *$ \\
\hline Protein intake $(\mathrm{g} / \mathrm{kgBM})^{3}$ & $1.0 \pm 0.2$ & $0.9 \pm 0.2$ & $1.1 \pm 0.2$ & $1.1 \pm 0.3$ & $0.9 \pm 0.1$ & $1.2 \pm 0.2 *$ \\
\hline $\mathrm{Fat}_{\max }(\mathrm{g} / \mathrm{min})$ & $0.43 \pm 0.10$ & $0.52 \pm 0.12$ & $0.43 \pm 0.11 *$ & & $0.52 \pm 0.11$ & $0.55 \pm 0.04$ \\
\hline $\mathrm{VO}_{2 \max }(\mathrm{mL} / \mathrm{min})$ & $2804 \pm 855$ & $2549 \pm 597$ & $2889 \pm 932$ & & $2946 \pm 862$ & $3004 \pm 508$ \\
\hline $\mathrm{VO}_{2 \max } / \mathrm{FFM}(\mathrm{mL} / \mathrm{min} / \mathrm{kg})$ & $50.6 \pm 7.4$ & $46.7 \pm 9.5$ & $51.9 \pm 6.5$ & & $54.1 \pm 6.2$ & $57.0 \pm 2.3$ \\
\hline Baecke ${ }^{4}$ & $9.2 \pm 1.4$ & $8.8 \pm 1.0$ & $9.4 \pm 1.5$ & $9.0 \pm 1.0$ & $9.0 \pm 0.7$ & $9.1 \pm 1.1$ \\
\hline Sport $^{4}$ & $3.5 \pm 0.9$ & $3.6 \pm 0.7$ & $3.5 \pm 0.9$ & $3.5 \pm 0.7$ & $3.6 \pm 0.7$ & $3.4 \pm 0.7$ \\
\hline Leisure time $^{4}$ & $3.5 \pm 0.4$ & $3.3 \pm 0.4$ & $3.5 \pm 0.5$ & $3.4 \pm 0.5$ & $3.3 \pm 0.4$ & $3.5 \pm 0.5$ \\
\hline Work $^{4}$ & $2.3 \pm 0.7$ & $2.1 \pm 0.2$ & $2.4 \pm 0.8$ & $2.1 \pm 0.5$ & $2.1 \pm 0.2$ & $2.1 \pm 0.6$ \\
\hline \multicolumn{7}{|c|}{$\begin{array}{l}\text { Mean valuess } \pm \text { standard deviations of the protein and control diet groups. } \\
* \text { p }<0.05 \text {; changes over time compared to baseline within groups. } \\
{ }^{1} \text { Body composition of the 4-compartment model of Lohman; } \% \mathrm{FM}=(274.7 / \mathrm{Db}-71.4 \mathrm{TBW} / \mathrm{BM} \\
+114.6 \mathrm{BMC} / \mathrm{BM}-205.03) \text {. } \\
{ }^{2} \text { Plasma concentrations after overnight fasting, } \mathrm{n}=15 \text { at } 3 \text { months. } \\
{ }^{3} \text { Based on } 24 \text {-hour urinary nitrogen nitrogen content, } 3 \text {-months value is the average of } 1.5 \text { and } 3 \\
\text { months. } \\
{ }^{4} \text { The Baecke total activity index and its activity sub-scores of sport, leisure time and work. }\end{array}$} \\
\hline
\end{tabular}

Fat $_{\max }$ significantly increased in the protein group $(0.08 \pm 0.08 \mathrm{~g} / \mathrm{min}, \mathrm{p}<0.01)$. Change in $\mathrm{Fat}_{\max }$ was a function of change in protein intake $(\mathrm{r}=0.623, \mathrm{p}<0.05)$. Thus, increased protein intake explained $39 \%$ of the variation in increase in Fatmax. At baseline, Fatmax was a function of body weight $(\mathrm{r}=0.621, \mathrm{p}<0.05)$, fat free mass $(\mathrm{r}=0.604, \mathrm{p}<0.05)$, and $\mathrm{VO}_{2 \max }(\mathrm{r}=0.621, \mathrm{p}<0.05)$. Change in $\mathrm{Fat}_{\max }$ was not a function of change in body weight, change in fat free mass, or change in $\mathrm{VO}_{2 \max }$. Taking 
covariates change in body weight or change in $\mathrm{VO}_{2 \max }$ into account Fat $\mathrm{max}_{\max }$ still significantly increased in the protein group $(\mathrm{p}<0.05)$. Body weight and $\mathrm{VO}_{2 \max }$ did not change over time. Taking change in fat free mass into account Fat max $_{\text {ax }}$ changed as a trend $(\mathrm{p}=0.060)$. As a result of the increase in protein intake fat free mass increased, and fat mass and fat percentage decreased over time $(p<0.05)$, which resulted in a significant change in fat percentage over time between the protein and control group $(\mathrm{p}<0.05)$.

Total activity index of the Baecke-questionnaire and its sub-scores sport, leisure time and work, $\mathrm{VO}_{2 \max }$ and $\mathrm{VO}_{2 \max } / \mathrm{FFM}$ (fat free mass) did not change. At baseline, all subjects cycled on average $25 \mathrm{~min} 52 \mathrm{sec} \pm 3 \mathrm{~min} 37 \mathrm{sec}$ and reached a maximal power output of $226 \pm 67$ Watt and maximal heart rate of $187 \pm 7$ beats per minute during the graded bicycle test to exhaustion. Figure 6.1 illustrates subjects' fat oxidation in function of their $\mathrm{VO}_{2 \max }$ and power output during the bicycle test at baseline. Fat max $_{\max }$ was $0.43 \pm 0.10 \mathrm{~g} / \mathrm{min}$ at $51 \pm 10 \% \mathrm{VO}_{2 \max }$, and at a power output of $97 \pm 35 \mathrm{Watt}$ and a heart rate of $130 \pm 16$ beats per minute. Fat ${ }_{\max }$ resulted in $63 \pm 17 \%$ of energy expenditure with a carbohydrate oxidation of $0.65 \pm 0.46 \mathrm{~g} / \mathrm{min}$.

Body composition, stimulated fat oxidation and protein intake have been determined with high accuracy. Combination of densitometry with measurements of total body water and bone mineral content determined the 4-compartment model of subjects' body composition. Furthermore, we used 24-hour urine nitrogen concentrations, which are more applicable to quantify protein intakes because dietary record methods are prone to misreporting (27). The graded bicycle test with continuous indirect calorimetric measurements allowed precise determination of maximal fat oxidation.

The relative exercise intensity that elicited maximal fat oxidation of $51 \% \mathrm{VO}_{2 \max }$ after an overnight fast in our subjects is comparable with the 43-64\% $\mathrm{VO}_{2 \max }$ observed in previous studies after an overnight fast in trained and untrained men $(28,29)$ and with the $48-56 \% \mathrm{VO}_{2 \max }$ in a post-absorptive state 3-4 hours after a meal in men and women $(30,31)$.

In conclusion, in subjects with increased protein intake stimulated fat oxidation was increased. Stimulated fat oxidation was a function of protein intake, body composition and $\mathrm{VO}_{2 \max }$. Yet, overall change in stimulated fat oxidation was a function of change in protein intake and not of change in body composition or $\mathrm{VO}_{2 \max }$.

\section{ACKNOWLEDGEMENTS}

We gratefully acknowledge Loek Wouters and Paul Schoffelen and Edith van den Hooven for their assistance. The study was supported by Top Institute Food and Nutrition (TIFN, Wageningen, The Netherlands). 


\section{REFERENCES}

1. Mittendorfer B, Fields DA, Klein S. Excess body fat in men decreases plasma fatty acid availability and oxidation during endurance exercise. Am J Physiol Endocrinol Metab 2004;286:E354-62.

2. Kelley DE, Goodpaster B, Wing RR, Simoneau JA. Skeletal muscle fatty acid metabolism in association with insulin resistance, obesity, and weight loss. Am J Physiol 1999;277:E1130-41.

3. Romijn JA, Coyle EF, Sidossis LS, et al. Regulation of endogenous fat and carbohydrate metabolism in relation to exercise intensity and duration. Am J Physiol 1993;265:E380-91.

4. Hickner RC, Privette J, McIver K, Barakat H. Fatty acid oxidation in African-American and Caucasian women during physical activity. J Appl Physiol 2001;90:2319-24.

5. Lejeune MP, Kovacs EM, Westerterp-Plantenga MS. Additional protein intake limits weight regain after weight loss in humans. Br J Nutr 2005;93:281-9.

6. Westerterp-Plantenga MS, Lejeune MP, Nijs I, van Ooijen M, Kovacs EM. High protein intake sustains weight maintenance after body-weight loss in humans. Int J Obes Relat Metab Disord 2004;28:57-64.

7. Skov AR, Toubro S, Ronn B, Holm L, Astrup A. Randomized trial on protein vs carbohydrate in ad libitum fat reduced diet for the treatment of obesity. Int J Obes Relat Metab Disord 1999;23:528-36.

8. Baba NH, Sawaya S, Torbay N, Habbal Z, Azar S, Hashim SA. High protein vs high carbohydrate hypoenergetic diet for the treatment of obese hyperinsulinemic subjects. Int J Obes Relat Metab Disord 1999;23:1202-6.

9. Wolfe RR. The underappreciated role of muscle in health and disease. Am J Clin Nutr 2006;84:475-82.

10. Harber MP, Schenk S, Barkan AL, Horowitz JF. Effects of dietary carbohydrate restriction with high protein intake on protein metabolism and the somatotropic axis. J Clin Endocrinol Metab 2005;90:5175-81.

11. Lohman TG. Advances in Body Composition Assesment. 1st ed. Champaign, IL, 1992.

12. Westerterp KR, Wouters L, van Marken Lichtenbelt WD. The Maastricht protocol for the measurement of body composition and energy expenditure with labeled water. Obes Res 1995;3 Suppl 1:49-57.

13. Schoeller DA, van Santen E, Peterson DW, Dietz W, Jaspan J, Klein PD. Total body water measurement in humans with $18 \mathrm{O}$ and 2H labeled water. Am J Clin Nutr 1980;33:2686-93.

14. Achten J, Gleeson M, Jeukendrup AE. Determination of the exercise intensity that elicits maximal fat oxidation. Med Sci Sports Exerc 2002;34:92-7.

15. Bishop D, Jenkins DG, Mackinnon LT. The effect of stage duration on the calculation of peak VO2 during cycle ergometry. J Sci Med Sport 1998;1:171-8.

16. Philippaerts RM, Westerterp KR, Lefevre J. Doubly labelled water validation of three physical activity questionnaires. Int J Sports Med 1999;20:284-9.

17. Lejeune MP, Westerterp KR, Adam TC, Luscombe-Marsh ND, Westerterp-Plantenga MS. Ghrelin and glucagon-like peptide 1 concentrations, 24-h satiety, and energy and substrate metabolism during a high-protein diet and measured in a respiration chamber. Am J Clin Nutr 2006;83:89-94.

18. Westerterp KR, Smeets A, Lejeune MP, Wouters-Adriaens MP, Westerterp-Plantenga MS. Dietary fat oxidation as a function of body fat. Am J Clin Nutr 2008;87:132-5.

19. Halliday D, Hesp R, Stalley SF, Warwick P, Altman DG, Garrow JS. Resting metabolic rate, weight, surface area and body composition in obese women. Int J Obes 1979;3:1-6.

20. Ravussin E, Lillioja S, Anderson TE, Christin L, Bogardus C. Determinants of 24-hour energy expenditure in man. Methods and results using a respiratory chamber. J Clin Invest 1986;78:1568-78.

21. Phillips SM. Physiologic and molecular bases of muscle hypertrophy and atrophy: impact of resistance exercise on human skeletal muscle (protein and exercise dose effects). Appl Physiol Nutr Metab 2009;34:403-10. 
22. Paddon-Jones D, Sheffield-Moore M, Zhang XJ, et al. Amino acid ingestion improves muscle protein synthesis in the young and elderly. Am J Physiol Endocrinol Metab 2004;286:E321-8.

23. Tessari P, Kiwanuka E, Zanetti M, Barazzoni R. Postprandial body protein synthesis and amino acid catabolism measured with leucine and phenylalanine-tyrosine tracers. Am J Physiol Endocrinol Metab 2003;284:E1037-42.

24. van Milgen J. Modeling biochemical aspects of energy metabolism in mammals. J Nutr 2002;132:3195-202.

25. Halton TL, Hu FB. The effects of high-protein diets on thermogenesis, satiety and weight loss: a critical review. J Am Coll Nutr 2004;23:373-85.

26. Rasmussen BB, Wolfe RR. Regulation of fatty acid oxidation in skeletal muscle. Annu Rev Nutr 1999;19:463-84.

27. Westerterp KR, Goris AH. Validity of the assessment of dietary intake: problems of misreporting. Curr Opin Clin Nutr Metab Care 2002;5:489-93.

28. Nordby P, Saltin B, Helge JW. Whole-body fat oxidation determined by graded exercise and indirect calorimetry: a role for muscle oxidative capacity? Scand J Med Sci Sports 2006;16:20914.

29. Achten J, Jeukendrup AE. Maximal fat oxidation during exercise in trained men. Int J Sports Med 2003;24:603-8.

30. Stisen AB, Stougaard O, Langfort J, Helge JW, Sahlin K, Madsen K. Maximal fat oxidation rates in endurance trained and untrained women. Eur J Appl Physiol 2006;98:497-506.

31. Venables MC, Achten J, Jeukendrup AE. Determinants of fat oxidation during exercise in healthy men and women: a cross-sectional study. J Appl Physiol 2005;98:160-7. 



\section{EFFICACY OF ALPHA-LACTALBUMIN}

FOR WEIGHT LOSS COMPARED TO

\section{SUSTAINED AND SUPRA-SUSTAINED MILK PROTEIN}

StiJn Soenen, ANANDa HochSTEnbaCh-WAELEN

AND MARgRiet S WesterterP-Plantenga

SUBMITTED FOR PUBLICATION 


\section{ABSTRACT}

\section{Objective}

Our objective was to examine if elevated alpha-lactalbumin (Alphalac) protein intake compared to supra-sustained (SSP) and sustained (SP) milk-protein intake results into a difference in body weight and body composition over a 6-month intervention.

\section{Design}

Body weight (BM) and body composition of 87 subjects (BMI $31 \pm 5 \mathrm{~kg} / \mathrm{m}^{2}$ and fat percentage $40 \pm 8 \%$ ), resting energy expenditure, satiety and blood- and urineparameters were assessed before and after energy intakes of $100 \%, 33 \%$ and $67 \%$ for 1 , 1 and 2-months respectively (periods 1, 2 and 3), with protein intake from mealreplacements and 2 -months of $67 \%$ including ad libitum protein intake additional to the meal-replacements (period 4). The diets consisted of $10 / 50 / 40 \mathrm{E} \%$ for SP and 20/50/30E\% for SSP and Alphalac of protein/carbohydrate/fat at baseline and resulted in $0.8 \pm 0.3 \mathrm{~g} / \mathrm{kgBM}$ for SSP and significant higher protein intake (24-hour nitrogen) of $1.2 \pm 0.3 \mathrm{~g} / \mathrm{kgBM}$ and $1.0 \pm 0.3 \mathrm{~g} / \mathrm{kgBM}$ for SSP and Alphalac $(\mathrm{p}<0.05)$.

\section{Results}

Body weight and fat percentage decreased in all groups after 6 months (SP $-7 \pm 5 \mathrm{~kg}$ and $-5 \pm 3 \%$; SSP $-6 \pm 3 \mathrm{~kg}$ and $-5 \pm 3 \%$; alphalac $-6 \pm 4 \mathrm{~kg}$ and $-4 \pm 4 \%, \mathrm{p}<0.001)$. Fat free mass decreased in all groups less compared to its predicted decrease of $33 \%$. The proportion of decreased fat free mass on decreased body weight was $24 \%$ for SP, $7 \%$ for SSP and $12 \%$ for Alphalac after 4 months. Reduction of resting energy expenditure as a function of fat free mass of the Alphalac-group was comparable with the SP-group and slightly higher compared to the SSP-group.

\section{Conclusion}

The efficacy of alpha-lactalbumin on reduction of body weight and fat mass, and preservation of fat free mass and resting energy expenditure is situated between the efficacy of equivalent and lower daily intakes of milk-protein over a relatively longterm period of time.

\section{Keywords}

alphalac, protein leverage, fat free mass, resting energy expenditure, weight loss 


\section{INTRODUCTION}

As overweight and obesity are associated with increased risk of several diseases, it is relevant to reduce the excess of body weight. Body weight decreases when energy expenditure exceeds energy intake. Energy intake is mainly influenced by appetite and satiety, whereas energy expenditure is mainly influenced by body composition, as fat free mass is the main predictor of resting and 24-hour energy expenditure $(1,2)$. Therefore it is relevant to spare fat free mass during the negative energy balance needed to achieve body-weight loss. In daily life successful loss of body weight by means of energy restriction will be reached by an energy-inefficient diet with high satiety capacity. Regarding the macronutrient composition of the diet, elevated protein diets have gained interest; of all macronutrients proteins have shown to be the most satiating (3-6), to be the most thermogenic (6-9), and to promote the highest ratio of fat free mass to fat mass during energy restriction $(3,5,10-17)$. Regarding the type of protein, digestion and absorption rate and amino acid composition may play a role; the 'fast-absorbable' whey-protein has a more pronounced satiety and peak amino acid concentrations compared to the 'slow-absorbable' casein (18). However, when different proteins are consumed at very high levels protein induced satiety is very high, and therefore differences in satiating effects are difficult to observe. In two studies, effects between whey and casein protein were not detectable with high-protein meals inducing larger satiating effect than high-carbohydrate meals $(19,20)$. Besides amount and type of protein, particular the amino acid tryptophan, a precursor of the neurotransmitter serotonin (21), may be involved in appetite regulation via serotonins anorexigenic effects in the brain (22). Alpha-lactalbumin, a whey peptide containing relatively high levels of tryptophan and relatively low levels of large neutral amino acids, prolonged suppression of hunger compared to gelatin, a collagen hydrolysate containing very low levels of tryptophan (23). The question remains whether these short-term effects on appetite regulation, also hold during a relative long period of energy restriction, resulting in differences in body-weight loss. Therefore, the aim of this study was to compare possible differences in reduction of body weight as a result of elevated alpha-lactalbumin protein intake compared to elevated and sustained milkprotein diets in 4 different phases of energy intake during 6 months.

\section{SUBJECTS AND METHODS}

The study was conducted following a randomized parallel design including 3 energyrestriction diets differing in protein content, namely sustained milk-protein (SP), suprasustained milk-protein (SSP), and supra-sustained alpha-lactalbumin protein (Alphalac). The Medical Ethics committee of Maastricht University Medical Centre approved the study. All participants gave written informed consent.

\section{Participants}

Participants were recruited with advertisements in local newspapers. The studyprotocol was explained orally and a paper version was handed-out. Inclusion criteria were age $18-80$ years and BMI $>25 \mathrm{~kg} / \mathrm{m}^{2}$. Exclusion criteria were smoking, the use of medication except the use of contraceptives for women, underlying malignity, more than $10 \%$ reduction of body weight during the last 6 months, and women who were 


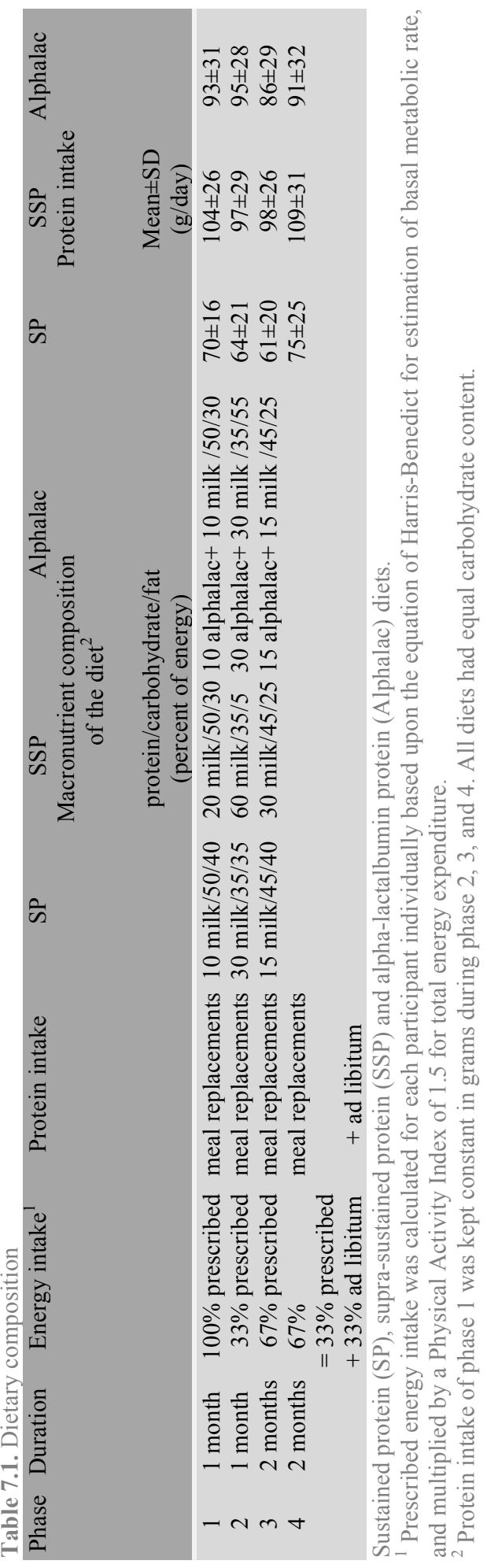


pregnant or breastfeeding. From the 87 participants who started, 25 dropped-out; 10 in the SP group, 6 in the SSP, and 9 in the alphalac; or 4,3,5 during the strict energyrestriction phase; 4,3,3 more during the mild energy-restriction phase; and 1,0,2 during the ad libitum phase in the SP-, SSP-, and alphalac-group respectively. Participants stopped due to several reasons, such as personal reasons and inability to fulfill the schedule with visits to the clinic.

\section{Dietary intervention}

The study had a duration of 6 months and consisted of 4 phases (Table 7.1). The first phase was run-in phase of 1 month prescribed energy intake at the level of $100 \%$ of subject specific energy requirements, and a protein source supplied from meal replacements. The second phase was 1 month of prescribed energy intake of $33 \%$ with the protein source supplied from meal replacements. The third phase was 2 months of prescribed energy intake of $67 \%$ with the protein source supplied from meal replacements. The forth phase were 2 months to examine the impact of weight development after these energy-restriction periods, where participants consumed food ad libitum in combination with prescribed intake of $33 \%$ to reach energy intake of about $67 \%$.

Prescribed energy intake was calculated for each participant individually based upon the equation of Harris-Benedict (24) for estimation of basal metabolic rate, and multiplied by a Physical Activity Index (PAL) of 1.5 for total energy expenditure. Baseline protein intake of phase 1 was kept constant in grams during the entire study according to the protein leverage hypothesis (25) to ensure sufficient protein availability for the preservation of fat free mass. Furthermore, both diets had equal carbohydrate content. Therefore, the macronutrient composition in percentage of energy changes in the different phases during the study, but the absolute protein content in grams is stable throughout the duration of the study. According to the protein leverage hypothesis individuals do not overconsume energy when the diet has an increased protein to carbohydrate and fat ratio, or a sustained protein intake during reduced energy intake. However, when the diet has a decreased protein to carbohydrate and fat ratio individuals overeat until the daily intake target amount of protein is ingested, and not the target of total energy intake where there would still be a deficit of protein intake (25). Diets were customized meal replacements containing milk-protein for both milk-protein diets or containing a 50/50 mixture of alpha-lactalbumin and milk-protein for the Alphalac-diet to reach protein content of the diet. The meal replacements contained per $100 \mathrm{~g}: 61 \mathrm{~g}$ milk-protein, $27 \mathrm{~g}$ carbohydrate (lactose), and $1 \mathrm{~g}$ fat. The meal replacements were combined with prescribed food items to match macronutrient content of the diet. Subjects were instructed to consume daily at least $200 \mathrm{~g}$ of fruit and $300 \mathrm{~g}$ of vegetables, and to maintain their customary level of physical activity during the entire duration of the study.

\section{Measurements}

Participants were familiarized with the equipment and the procedures before the start of all measurements. Anthropometry, body composition and urinary nitrogen were measured at baseline and after phases 1, 2, 3 and 4. Energy expenditure and blood 
parameters were measured at baseline and after phases 1,2 and 3, and not after phase 4 because participants where allowed to partly consume food ad libitum during phase 4 .

Height was measured at screening to the nearest $0.1 \mathrm{~cm}$ (Seca-stadiometer, model 220, Hamburg, Germany). Body weight was measured with subjects in underwear after an overnight fast using a calibrated scale of the Bod $\operatorname{Pod}^{\circledR}$. Body mass index (BMI) was calculated by dividing body weight by height squared $\left(\mathrm{kg} / \mathrm{m}^{2}\right)$. Waist circumference was measured at the site of smallest circumference between rib cage and iliac crest and hip circumference was measured at the site of largest circumference between waist and thighs. Systolic and diastolic blood pressures were recorded using an automatic blood pressure monitor with subjects in sitting position (OMRON M6, Hoofddorp, The Netherlands).

Body composition was calculated from body volume of the Bod $\operatorname{Pod}^{\circledR}$ (Life measurement, Concord, CA, USA) (26) and total body water (TBW) of the deuteriumdilution technique (27) using Siri's three-compartment model (28). The dilution of the deuterium isotope $\left({ }^{2} \mathrm{H}_{2} \mathrm{O}\right)$ is a measure for total body water. Fat free mass was calculated by dividing total body water by the hydrating factor 0.73 . Participants wore tightly fitting bathing suits and a swim cap during the volume-measurements of the $\operatorname{Bod} \operatorname{Pod}^{\circledR}$, and had not engaged in exercise at least 1 hour prior to the test.

Resting energy expenditure was measured with subjects lying supine by means of an open circuit ventilated hood system. Gas analysis was performed by a paramagnetic oxygen analyzer (Omnical type 1155B, Crowborough Sussex, UK) and an infrared carbon dioxide analyzer (Omnical type 1520/1507). Resting energy expenditure was calculated using Weir's formula. The respiratory quotient (RQ) was calculated as $\mathrm{CO}_{2}$ produced/ $\mathrm{O}_{2}$ consumed.

To determine physical activity the validated Baecke-questionnaire was used (29).

To determine whether attitudes towards food intake changed during the experiment, a validated Dutch translation of the Three Factor Eating Questionnaire (TFEQ) was used.

Fasting venous blood samples were taken to analyze concentrations of plasma glucagon-like-peptide-1 (GLP-1), Peptide-YY (PYY) 3-36, insulin, glucose, FFA, TAG, and HDL, LDL and total cholesterol, and creatinin. Plasma was obtained by centrifugation $\left(1500^{*} \mathrm{~g}\right.$ for $10 \mathrm{~min}$ at $4^{\circ} \mathrm{C}$ ), frozen in liquid nitrogen and stored at $-80^{\circ} \mathrm{C}$ until analysis. Blood samples were collected in tubes containing EDTA to prevent clotting. Blood samples for GLP-1 and PYY analysis were collected in ice-chilled syringes containing $20 \mu \mathrm{l}$ of dipeptidyl peptidase-IV (DPP-IV) inhibitor (Linco Research Inc., St. Charles, Missouri, USA) to prevent degradation. Blood samples for PYY analysis were mixed with Trasylol (Bayer Diagnostics Europe Ltd, The Netherlands). Concentrations of active GLP-1 were measured by ELISA (EGLP-35K; Linco Research Inc., ST Charles, Missouri, USA). Concentrations of PYY and insulin were measured by RIA (Linco Research Inc., St Charles, Missouri, USA; Insulin RIA100; Kabi-Pharmacia, Uppsala, Sweden). Glucose concentrations were measured using the hexokinase method (Glucose HK 125 kit; ABX diagnostics, Montpellier, France). HOMA-index was calculated by glucose (mmol/L)*insulin (mUnits/L)/22.5. Concentrations of FFA were determined with the Wako NEFA C-kit (Wako chemicals, Neuss, Germany). Concentrations of TAG were measured using the GPO-trinder kit (Sigma Diagnostics Inc., St Louis, MO, USA). Total cholesterol was measured with 
the cholesterol 100 kit (ABX diagnostics, Montpellier, France) and HDL cholesterol with a combination of the cholesterol 100 kit and the HDL-C kit (Roche Diagnostics GmBH, Mannheim, Germany). LDL cholesterol was calculated according to the Friedewald (30) formula.

Urine samples were collected for 24 hours in containers with $10 \mathrm{~mL} \mathrm{H}_{2} \mathrm{SO}_{4}$ to prevent nitrogen loss through evaporation. Volume and nitrogen concentration were measured, the latter with a nitrogen analyzer (CHN-O-Rapid; Heraeus, Hanau, Germany).

\section{Statistical analysis}

Data are presented as means with standard deviations unless otherwise stated. Differences between groups were tested by ANCOVA with baseline values as covariate. Changes over time between and within groups were tested by factorial repeated-measures ANOVA with Bonferroni post hoc corrections. Differences were regarded as significant if $\mathrm{p}<0.05$. All analyses were performed with the Statistical Package for the Social Sciences (SPSS) version 16.0.2 for Macintosh OS X.

\section{RESULTS}

\section{Protein intake}

Protein intake, determined according to 24-hour urinary nitrogen, was significantly higher in the Alphalac-diet compared to the control sustained-protein (SP) diet in the first 3 periods $(95 \%$ CI 6 to 36,11 to 42 and 2 to $36 \mathrm{~g}, \mathrm{p}<0.05)$. The Alphalac and supra-sustained-protein (SSP) diets with protein intakes above their requirements did not differ in protein intake. Furthermore, baseline protein intake did not differ between groups (SP; $71 \pm 24 \mathrm{~g}$ or $0.8 \pm 0.3 \mathrm{~g} / \mathrm{kgBM}, \mathrm{SSP} ; 81 \pm 31 \mathrm{~g}$ or $0.9 \pm 0.3 \mathrm{~g} / \mathrm{kgBM}$, and alphalac; $77 \pm 23$ g or $0.8 \pm 0.3 \mathrm{~g} / \mathrm{kgBM}$ ).

The SP-diet resulted in protein intakes comparable with baseline during periods 1 , 2 and $3 ; 70 \pm 16,64 \pm 21$ and $61 \pm 20 \mathrm{~g}$ or $0.8 \pm 0.2,0.8 \pm 0.3$ and $0.8 \pm 0.3 \mathrm{~g} / \mathrm{kgBM}$ with meal substitutes as protein source and prescribed energy intakes of $100 \%, 33 \%$ and $67 \%$ respectively. Thus, subjects of the SP-group were able to maintain their intake of protein requirement, even with energy restriction up to $-67 \%$. The ad libitum protein intake additional to the meal substitutes during period 4 resulted in significantly increased protein intake of $75 \pm 25 \mathrm{~g}$ or $1.0 \pm 0.4 \mathrm{~g} / \mathrm{kgBM}(\mathrm{p}<0.01)$.

The SSP- and Alphalac-diet resulted in significantly increased protein intakes compared to baseline during all periods; SSP: $104 \pm 26,97 \pm 29,98 \pm 26$ and $109 \pm 31 \mathrm{~g}$ or $1.2 \pm 0.3,1.2 \pm 0.3,1.2 \pm 0.3$ and $1.3 \pm 0.4 \mathrm{~g} / \mathrm{kgBM}(\mathrm{p}<0.05)$, alphalac: $93 \pm 31,95 \pm 28$, $86 \pm 29$ and $91 \pm 32 \mathrm{~g}$ or $1.0 \pm 0.3,1.2 \pm 0.4,1.1 \pm 0.4$ and $1.1 \pm 0.4 \mathrm{~g} / \mathrm{kgBM}(\mathrm{p}<0.05)$. Thus, subjects of the Alphalac- and SSP-group were able to increase their absolute protein intake, resulting in higher intakes of protein the Alphalac-group compared to the subjects of the SP-group (treatment over time in all 4 periods; 95\%CI 7 to 38, 13 to 48 and 7 to $43 \mathrm{~g}, \mathrm{p}<005$ ) and similar intakes compared to the SSP-group during the 6 months of intervention. 


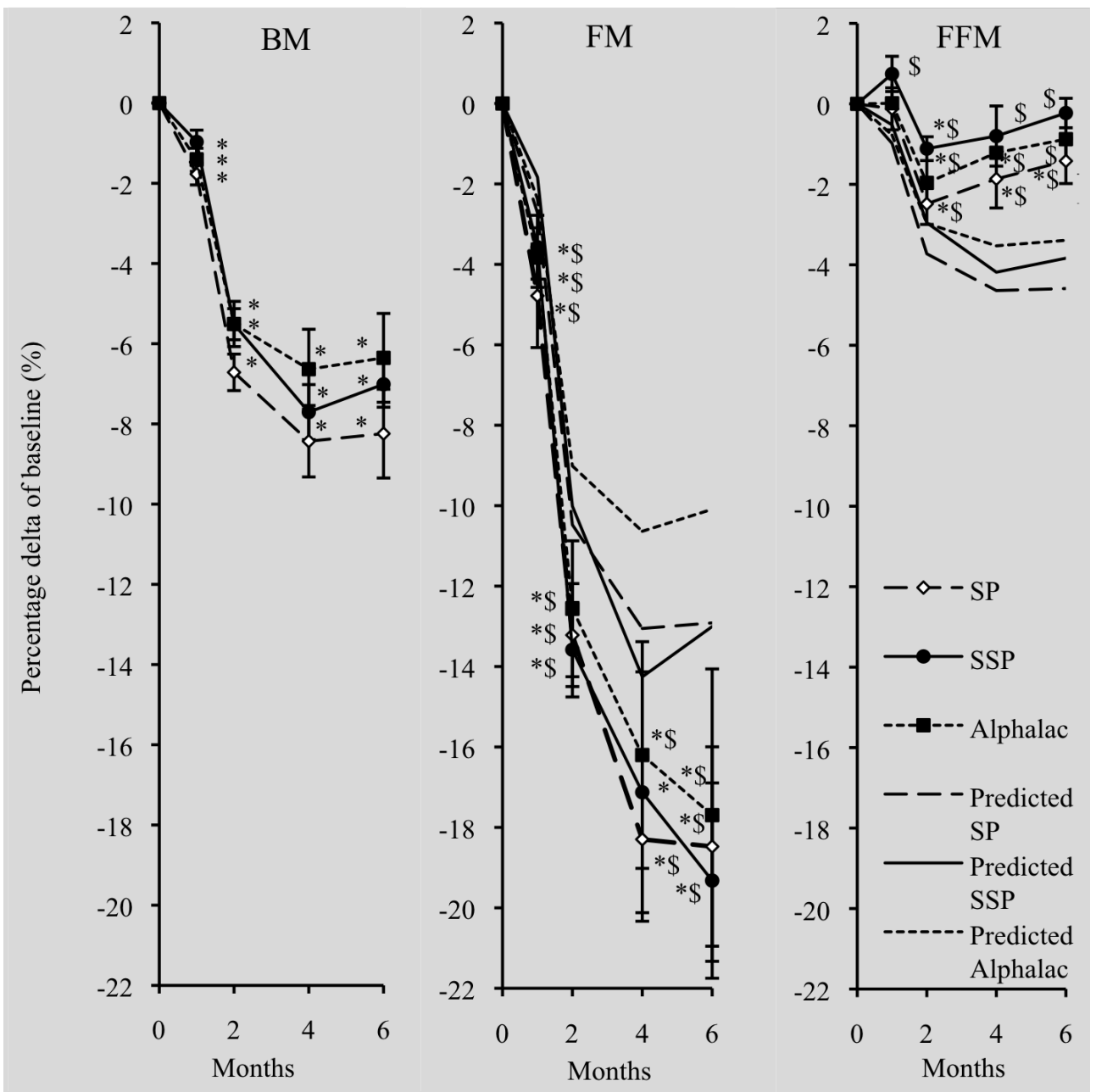

Figure 7.1. Mean and SEM of body weight, measured and predicted fat mass (1/3 of the decrease in body weight) and measured and predicted fat free mass ( $2 / 3$ of the decrease in body weight)

$* \mathrm{p}<0.05$; changes over time compared to baseline within groups.

No treatment over time of alpha-lactalbumin (Alphalac) vs. sustained-protein (SP) and vs. suprasustained-protein (SSP).

$\$ \mathrm{p}<0.05$; measured vs. predicted fat mass or fat free mass.

\section{Body weight and body composition}

All groups decreased in body weight, body mass index, fat mass, and fat percentage after 6 months compared to baseline (periods $1+2+3+4, p<0.001$, Table 7.2). Fat free mass did not change in the Alphalac- and SSP-group but decreased slightly in the SPgroup after 6 months $(\mathrm{p}<0.05)$. Furthermore, fat free mass decreased in the strict energy restriction period 2 of $-67 \%$ energy intake in all groups (Alphalac; $-2 \pm 2$, SSP; $-2 \pm 2$, and SP; $-2 \pm 3 \%$ change in fat free mass of start-value period $2, \mathrm{p}<0.05$ ). However, fat free mass decreased less and fat mass decreased more in all groups compared to their predicted decreases $(p<0.001$, Figure 7.1); predicted decrease in fat free mass is $33 \%$ and predicted decrease in fat mass is $67 \%$ of the decrease in body weight (31). 
The proportion of decreased fat free mass on decreased body weight was $24 \%$ for SP, $12 \%$ for Alphalac and 7\% for SSP after 4 months.

\section{Energy expenditure}

Baseline values of resting energy expenditure (REE) and respiratory quotient (RQ) did not differ between groups. RQ did not change after 4 months in all groups. Groups decreased in REE after 4 months compared to baseline (periods $1+2+3, \mathrm{p}<0.01$ ). REE was linearly related to fat free mass at baseline and after all 3 periods $(p<0.001)$. The regression line shifts down as body-weight loss progresses, indicating that REE decreases for a certain fat free mass as body weight decreases due to energy intake restriction. The regression line of the Alphalac-group shifts more compared to the SSPgroup and less compared to the SP-group. Predicted REE was calculated based on the regression equation of the whole study population at baseline; REE $=0.076 \mathrm{FFM}+$ $0.036 \mathrm{FM}+1.597\left(\mathrm{r}^{2}=0.806, \mathrm{n}=85\right)$ by filling in the fat free mass (FFM) and fat mass (FM) values from the respective period. The Alphalac- and SSP-group did not differ in measured compared to predicted REE after 4 months. However, in the Alphalac-group measured REE was lower compared to predicted REE after 1 and 2 months (-0.3 and $0.3 \mathrm{MJ} /$ day; $95 \% \mathrm{CI}-0.5$ to -0.1 and -0.5 to $-0.1 \mathrm{MJ} /$ day). Overall, the reduction of $\mathrm{REE}$ as a function of fat free mass over time of the Alphalac-group was comparable with the SP-group and slightly higher compared to the SSP-group.

\section{Waist- and hip-circumference}

Baseline values of and changes over time in waist- and hip-circumference and waisthip ratio did not differ between groups. All groups decreased in waist circumference after 6 months compared to baseline $(\mathrm{p}<0.05$, Table 7.2).

\section{Physiological characteristics}

Baseline values of and changes over time in fasted morning glucose, insulin or HOMA-index did not differ between groups. All groups decreased in insulin and HOMA-index after 4 months compared to baseline ( $p<0.01$, Table 7.3).

Baseline values of and changes over time in fasted morning FFA, TAG, HDL and LDL cholesterol, and baseline values of total cholesterol did not differ between groups. The control groups SP and SSP but not the Alphalac-group decreased in LDL and total cholesterol after 4 months compared to baseline $(p<0.001)$. Furthermore, total cholesterol decreased less in the Alphalac-group compared to the SSP-group after 4 months $(p<0.05)$. FFA, TAG and HDL did not change after 4 months.

Baseline values of and changes in systolic blood pressure, and baseline values of diastolic blood pressure did not differ between groups. All groups decreased in systolic and diastolic blood pressure after 6 months compared $(\mathrm{p}<0.05$, Table 7.2).

\section{Physical activity and eating behavior}

Baseline values of and changes over time in physical activity scores of the Baeckequestionnaire did not differ between groups (Table 7.4). All groups did not change in total physical activity over time during the 6 months of intervention.

Baseline values of and changes in Three Factor Eating Questionnaire (TFEQ) score of dietary restraint (F1), disinhibition (F2) and hunger (F3) did not differ between 


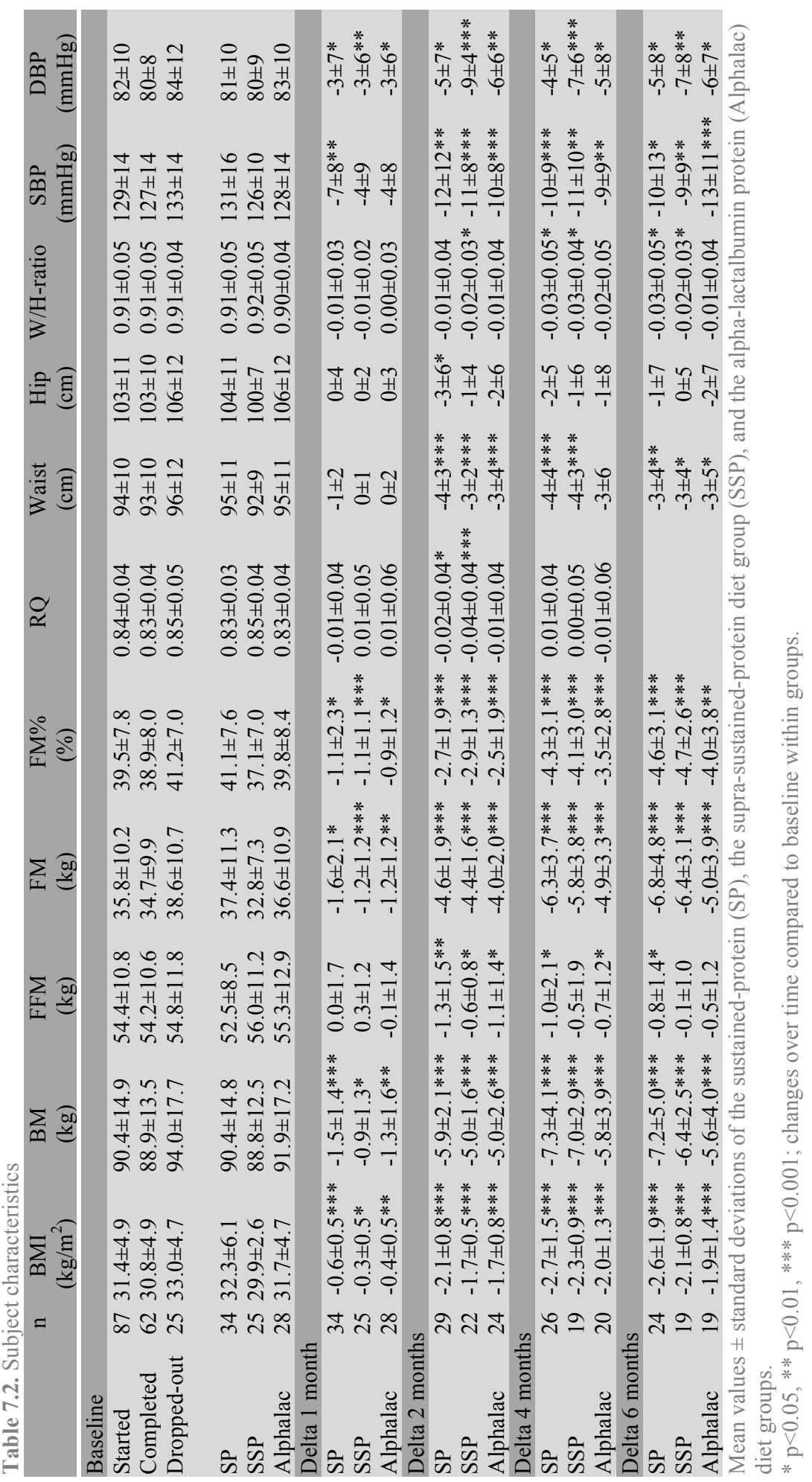




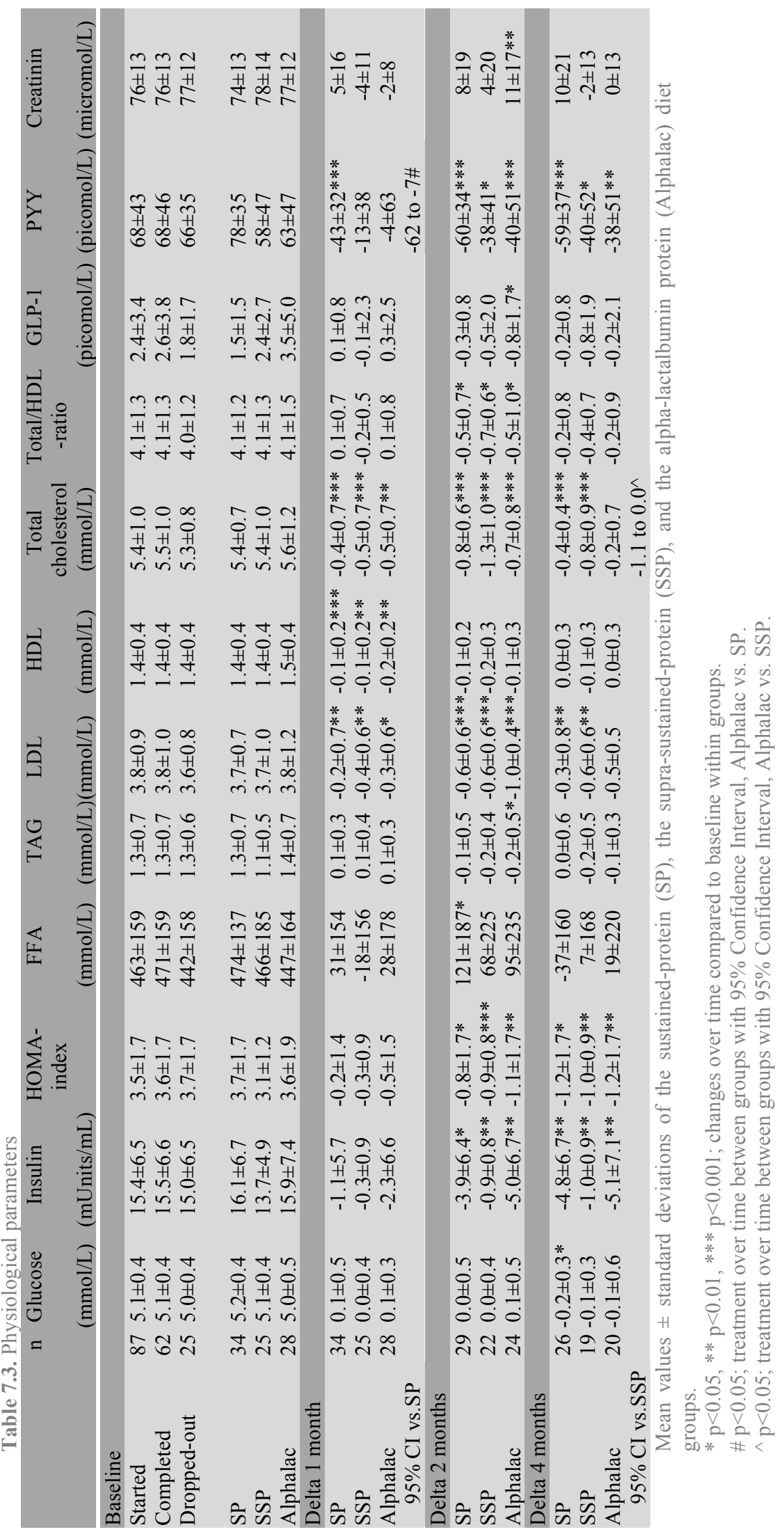


groups. All groups increased in F1-score and decreased in F2- and F3-scores after 6 months compared to baseline $(\mathrm{p}<0.05)$.

\section{Hunger and satiety}

Baseline values of and changes over time in or visual analogue scores (VAS) and fasted morning GLP-1, and baseline values of fasted morning PYY did not differ between groups. All groups did not change in VAS of hunger, desire to eat, prospective food consumption, thirst, desire to drink, prospective drink consumption, fullness and satiety over time during the 6 months of intervention. Furthermore, GLP-1 did not change after 4-months. However, all groups decreased in PYY after 4 months compared to baseline $(\mathrm{p}<0.01$, Table 7.3$)$.

Table 7.4. Physical activity and eating behavior

\begin{tabular}{|c|c|c|c|c|c|c|c|c|}
\hline & $\mathrm{n}$ & Work $^{1}$ & Sport $^{1}$ & Leisure time $^{1}$ & ${ }^{1}$ Baecke $^{1}$ & TFEQ F $1^{2}$ & TFEQ F $^{3}$ & TFEQ F3 $^{4}$ \\
\hline \multicolumn{9}{|l|}{ Baseline } \\
\hline Started & 87 & $2.6 \pm 0.6$ & $2.5 \pm 0.9$ & $3.1 \pm 0.5$ & $8.3 \pm 1.3$ & $8.2 \pm 4.1$ & $6.0 \pm 2.8$ & $4.8 \pm 3.0$ \\
\hline Completed & 62 & $2.7 \pm 0.6$ & $2.5 \pm 0.9$ & $3.1 \pm 0.6$ & $8.3 \pm 1.3$ & $8.6 \pm 4.3$ & $5.8 \pm 2.7$ & $4.7 \pm 3.1$ \\
\hline Dropped-out & 25 & $2.5 \pm 0.6$ & $2.6 \pm 0.9$ & $3.1 \pm 0.4$ & $8.3 \pm 1.1$ & $7.0 \pm 3.5$ & $6.6 \pm 3.1$ & $5.0 \pm 3.1$ \\
\hline SP & 34 & $2.8 \pm 0.5$ & $2.6 \pm 1.0$ & $3.1 \pm 0.6$ & & $8.2 \pm 4.1$ & $6.2 \pm 2.7$ & $4.7 \pm 3.0$ \\
\hline SSP & 25 & $2.6 \pm 0.6$ & $2.6 \pm 0.6$ & $3.0 \pm 0.5$ & $8.1 \pm 1.3$ & $8.2 \pm 4.5$ & $5.5 \pm 2.1$ & $4.4 \pm 2.7$ \\
\hline Alphalac & 28 & $2.6 \pm 0.7$ & $2.4 \pm 0.9$ & $3.2 \pm 0.5$ & $8.1 \pm 1.1$ & $8.1 \pm 3.9$ & $6.1 \pm 3.5$ & $5.3 \pm 3.5$ \\
\hline \multicolumn{9}{|c|}{ Delta 1 month } \\
\hline SP & 34 & $0.0 \pm 0.3$ & $0.1 \pm 0.5$ & $0.1 \pm 0.3$ & $0.2 \pm 0.6$ & $0.9 \pm 3.4$ & $-0.6 \pm 1.8$ & $-0.3 \pm 1.9$ \\
\hline SSP & 25 & $0.0 \pm 0.3$ & $0.0 \pm 0.3$ & $0.0 \pm 0.5$ & $0.1 \pm 0.7$ & $1.0 \pm 2.2 *$ & $-0.1 \pm 1.3$ & $-0.1 \pm 1.8$ \\
\hline Alphalac & 28 & $0.1 \pm 0.2$ & $0.2 \pm 0.4 *$ & $0.0 \pm 0.4$ & $0.3 \pm 0.5 * *$ & $* 1.5 \pm 2.8 * *$ & $-0.5 \pm 1.8$ & $-0.7 \pm 2.6$ \\
\hline \multicolumn{9}{|c|}{ Delta 2 months } \\
\hline SP & 29 & $0.0 \pm 0.3$ & $0.1 \pm 0.7$ & $0.2 \pm 0.3$ & $0.2 \pm 0.9$ & $2.3 \pm 3.9 *$ & $-1.4 \pm 2.2 *$ & $-1.7 \pm 3.0^{*}$ \\
\hline SSP & 22 & $0.0 \pm 0.2$ & $0.1 \pm 0.4$ & $0.1 \pm 0.6$ & $0.2 \pm 0.8$ & $1.8 \pm 3.0 *$ & $-0.8 \pm 1.9$ & $-0.9 \pm 2.3$ \\
\hline Alphalac & 24 & $0.2 \pm 0.3 *$ & * $0.4 \pm 0.6 * *$ & $-0.1 \pm 0.5$ & $0.5 \pm 0.7 * *$ & * $2.7 \pm 3.2 * * *$ & $-1.2 \pm 1.9 * *$ & $-1.1 \pm 1.6 * *$ \\
\hline \multicolumn{9}{|c|}{ Delta 4 months } \\
\hline SP & 26 & $-0.1 \pm 0.3$ & $0.0 \pm 0.8$ & $0.2 \pm 0.4^{*}$ & $0.1 \pm 1.2$ & $1.8 \pm 3.8 *$ & $-1.4 \pm 2.1 *$ & $-1.7 \pm 3.0^{*}$ \\
\hline SSP & 19 & $0.0 \pm 0.3$ & $0.1 \pm 0.4$ & $0.1 \pm 0.6$ & $0.2 \pm 0.7$ & $2.8 \pm 4.1 * *$ & $-0.9 \pm 1.4^{*}$ & $-1.9 \pm 2.7 *$ \\
\hline Alphalac & 20 & $0.1 \pm 0.4$ & $0.3 \pm 0.5 *$ & $-0.1 \pm 0.6$ & $0.2 \pm 1.2$ & $3.7 \pm 3.0 * * *$ & $-1.1 \pm 2.5$ & $-1.6 \pm 2.8 *$ \\
\hline \multicolumn{9}{|c|}{ Delta 6 months } \\
\hline SP & 24 & $-0.1 \pm 0.3$ & $-0.2 \pm 0.8$ & $0.3 \pm 0.4 * *$ & $0.0 \pm 1.1$ & $2.2 \pm 4.1^{*}$ & $-1.7 \pm 2.4^{*}$ & $-1.8 \pm 2.6^{*}$ \\
\hline SSP & 19 & $0.0 \pm 0.3$ & $0.0 \pm 0.3$ & $0.1 \pm 0.3$ & $0.1 \pm 0.6$ & $3.3 \pm 3.0 * *$ & $-0.7 \pm 1.5^{*}$ & $-1.9 \pm 2.9 *$ \\
\hline Alphalac & 19 & $0.1 \pm 0.3$ & $0.2 \pm 0.5$ & $-0.2 \pm 0.7$ & $0.2 \pm 1.2$ & $3.2 \pm 3.4 * * *$ & $-1.5 \pm 2.6^{*}$ & $-1.8 \pm 2.5 * *$ \\
\hline \multicolumn{9}{|c|}{$\begin{array}{l}\text { Mean values } \pm \text { standard deviations of the sustained-protein (SP), the supra-sustained-protein (SSP), } \\
\text { and the alpha-lactalbumin protein (Alphalac) diet groups. } \\
* \mathrm{p}<0.05, * * \mathrm{p}<0.01, * * * \mathrm{p}<0.001 \text {; changes over time compared to baseline within groups. } \\
\text { No treatment over time between groups. } \\
{ }^{1} \text { The Baecke total activity index and its activity sub-scores of sport, leisure time and work. } \\
{ }^{2} \text { A measure of cognitive restraint of the three-factor eating questionnaire (TFEQ); minimum score } 0 \text {, } \\
\text { maximum score } 21 \text {; cut-off point fort the Dutch population } 9 \text {. Values greater than } 9 \text { indicate cognitive } \\
\text { restraint eating. } \\
{ }^{3} \text { A measure of disinhibition or emotional eating of the TFEQ; minimum score } 0 \text {, maximum score } 14 \text {. } \\
{ }^{4} \text { A general feeling of hunger of the TFEQ; minimum score } 0 \text {, maximum score } 14 \text {. }\end{array}$} \\
\hline
\end{tabular}




\section{Kidney function}

Baseline values of and changes over time in fasted morning plasma creatinin did not differ between groups. The SP- but not the Alphalac- or SSP-group increased in creatinin after 4 months $(\mathrm{p}<0.05)$.

Remarkably, sustaining baseline required protein intake slightly increased serum creatinin, as the elevated protein intake of Alphalac and SSP did not change kidney function parameters over time. Indicating that the SP-group increased in muscle creatinphosphate metabolism or cleared less creatinin via the kidneys. The higher protein intake of the alphalac- and supra-sustained-protein diet did not result into reduced creatinin-clearence of the kidney. All groups remained between the range of normal-values; 60 to $120 \mathrm{micromol} / \mathrm{L}$.

\section{DISCUSSION}

Reduction of body weight and fat percentage was not affected by protein type, alphalactalbumin vs. milk-protein, or amount of protein during different phases of energy restriction. Fat mass decreased more as predicted from its decrease in body weight compared to the predicted decrease of fat mass of $67 \%$ (31); decrease of fat mass per amount of body-weight loss was $88 \%$ for Alphalac, $76 \%$ for SP and $93 \%$ for SSP. Furthermore, all protein diets were effective in sparing fat free mass during energyrestriction, as actual fat free mass decreased less compared to the predicted decrease. Thus, sparing of fat free mass was not affected by protein type. However, amount of protein affected sparing of fat free mass. Fat free mass decreased less after the extra protein intake of alpha-lactalbumin and supra-sustained-protein compared to sustainedprotein. Part of this sparing of fat free mass has been revealed; protein rich diets result into net muscle-protein synthesis (32-34) and increase energy expenditure due to the high energetic-cost of protein synthesis $(35,36)$. The successful sparing of fat free mass resulted in a slightly decrease in resting energy expenditure as a function of fat free mass in the alpha-lactalbumin and sustained-protein-group and no change over time in the supra-sustained-protein group after 4 months. Successful sparing of fat free mass and limited decrease of energy expenditure facilitates maintenance of reduced body weight, as was shown before with protein-rich diets $(5,11-14,37,38)$.

Our protocol succeeded in creating a contrast in protein intake between both elevated-protein diets; alpha-lactalbumin and supra-sustained-protein, vs. the sustained protein diet; sustained-protein ( 1.0 to 1.2 vs. $0.8 \mathrm{~g} / \mathrm{kgBM}$ ). Compliance to energy intake of the diet and therefore reduction of body weight $(4,15,39)$ is facilitated by the high satiation capacity of proteins (3-6). Studies on short-term effects, i.e. satiety and food intake, of whey proteins compared to casein indicated that whey proteins are promising for good compliance of a diet to lose weight. Whey (18) and its peptide alpha-lactalbumin (23) were more satiating and/or decreased food intake more compared to casein (18), or gelatin (23) or egg protein (40). Our results show that the efficacy of alpha-lactalbumin on reduction of body weight and fat mass, and preservation of fat free mass and resting energy expenditure is situated between the efficacy of equivalent and lower daily intakes of milk-protein over a relatively longterm period of time. So, the short-term promising higher satiety effects of alphalactalbumin, a whey peptide containing relatively high levels of tryptophan and 
relatively low levels of large neutral amino acids, did not result into better long-term effects compared to a complete protein having all essential amino acids; milk protein.

Subjective feeling of hunger of the TFEQ-questionnaire decreased in all protein diets. The amount of protein intake sustained the peripheral plasma concentrations of the nutrient-related hormone glucagon-like-peptide-1 during energy restriction. Peptide-YY, however decreased in all groups. Consonantly, dietary restraint, a measure of control of food intake by thought and will-power, increased, and disinhibition of control, an incidental inability to resist eating cues, decreased in both groups. Thus, increase in dietary restraint, and decrease in disinhibition and hunger reinforce good compliance of energy intake of the energy restriction phase resulting in successful reduction of body weight over time.

The metabolic profile was remarkably improved in the milk-protein groups; insulin, HOMA-index, LDL and total cholesterol decreased as a result of body-weight loss. Systolic and diastolic blood pressure decreased as well. As previously, proteinrich energy-restricted diets with successful loss of body weight influenced the metabolic profile positively $(13,14,38,41)$. However, the Alphalac-group did not decrease in LDL and total cholesterol. Therefore, it is not clear if these beneficial effects on the metabolic profile are driven by reduction of body weight or by macronutrient composition, i.e. elevated protein intake, or even type of protein.

As a result of the decrease in body weight, and probably due to elevation in protein intake as the supra-sustained-protein group resulted in a larger decrease compared to the sustained-protein diet.

In conclusion, reduction of body weight and fat percentage is not affected by amount or type; i.e. contrast in the level of the amino acid tryptophan, of protein. On the other hand, sparing of fat free mass is affected by amount of protein, and decrease in resting energy expenditure during body weight-reduction is affected by both amount and type of protein. All diets reduce body weight and fat percentage equally, while both elevated-protein diets; supra-sustained-protein and alpha-lactalbumin, spare more fat free mass, additionally the supra-sustained-protein diet preserved resting energy expenditure as a function of fat free mass during loss of body weight as well.

\section{ACKNOWLEDGEMENTS}

We gratefully acknowledge Freeha Faizi for her assistance. The study was supported by Top Institute Food and Nutrition (TIFN, Wageningen, The Netherlands). 


\section{REFERENCES}

1. Ravussin E, Lillioja S, Anderson TE, Christin L, Bogardus C. Determinants of 24-hour energy expenditure in man. Methods and results using a respiratory chamber. J Clin Invest 1986;78:1568-78.

2. Halliday D, Hesp R, Stalley SF, Warwick P, Altman DG, Garrow JS. Resting metabolic rate, weight, surface area and body composition in obese women. Int J Obes 1979;3:1-6.

3. Lejeune MP, Kovacs EM, Westerterp-Plantenga MS. Additional protein intake limits weight regain after weight loss in humans. Br J Nutr 2005;93:281-9.

4. Weigle DS, Breen PA, Matthys CC, et al. A high-protein diet induces sustained reductions in appetite, ad libitum caloric intake, and body weight despite compensatory changes in diurnal plasma leptin and ghrelin concentrations. Am J Clin Nutr 2005;82:41-8.

5. Westerterp-Plantenga MS, Lejeune MP, Nijs I, van Ooijen M, Kovacs EM. High protein intake sustains weight maintenance after body-weight loss in humans. Int J Obes Relat Metab Disord 2004;28:57-64.

6. Westerterp-Plantenga MS, Rolland V, Wilson SA, Westerterp KR. Satiety related to $24 \mathrm{~h}$ diet induced thermogenesis during high protein/carbohydrate vs high fat diets measured in a respiration chamber. Eur J Clin Nutr 1999;53:495-502.

7. Westerterp KR, Wilson SA, Rolland V. Diet induced thermogenesis measured over $24 \mathrm{~h}$ in a respiration chamber: effect of diet composition. Int J Obes Relat Metab Disord 1999;23:287-92.

8. Dauncey MJ, Bingham SA. Dependence of $24 \mathrm{~h}$ energy expenditure in man on the composition of the nutrient intake. Br J Nutr 1983;50:1-13.

9. Nair KS, Halliday D, Garrow JS. Thermic response to isoenergetic protein, carbohydrate or fat meals in lean and obese subjects. Clin Sci (Lond) 1983;65:307-12.

10. Krieger JW, Sitren HS, Daniels MJ, Langkamp-Henken B. Effects of variation in protein and carbohydrate intake on body mass and composition during energy restriction: a meta-regression 1. Am J Clin Nutr 2006;83:260-74.

11. Deibert P, Konig D, Schmidt-Trucksaess A, et al. Weight loss without losing muscle mass in preobese and obese subjects induced by a high-soy-protein diet. Int J Obes Relat Metab Disord 2004;28:1349-52.

12. Farnsworth E, Luscombe ND, Noakes M, Wittert G, Argyiou E, Clifton PM. Effect of a highprotein, energy-restricted diet on body composition, glycemic control, and lipid concentrations in overweight and obese hyperinsulinemic men and women. Am J Clin Nutr 2003;78:31-9.

13. Layman DK, Boileau RA, Erickson DJ, et al. A reduced ratio of dietary carbohydrate to protein improves body composition and blood lipid profiles during weight loss in adult women. J Nutr 2003;133:411-7.

14. Parker B, Noakes M, Luscombe N, Clifton P. Effect of a high-protein, high-monounsaturated fat weight loss diet on glycemic control and lipid levels in type 2 diabetes. Diabetes Care 2002;25:425-30.

15. Skov AR, Toubro S, Ronn B, Holm L, Astrup A. Randomized trial on protein vs carbohydrate in ad libitum fat reduced diet for the treatment of obesity. Int $J$ Obes Relat Metab Disord 1999;23:528-36.

16. Piatti PM, Monti F, Fermo I, et al. Hypocaloric high-protein diet improves glucose oxidation and spares lean body mass: comparison to hypocaloric high-carbohydrate diet. Metabolism 1994;43:1481-7.

17. Hoffer LJ, Bistrian BR, Young VR, Blackburn GL, Matthews DE. Metabolic effects of very low calorie weight reduction diets. J Clin Invest 1984;73:750-8.

18. Hall WL, Millward DJ, Long SJ, Morgan LM. Casein and whey exert different effects on plasma amino acid profiles, gastrointestinal hormone secretion and appetite. Br J Nutr 2003;89:239-48.

19. Bowen J, Noakes M, Trenerry C, Clifton PM. Energy intake, ghrelin, and cholecystokinin after different carbohydrate and protein preloads in overweight men. J Clin Endocrinol Metab 2006;91:1477-83. 
20. Bowen J, Noakes M, Clifton PM. Appetite regulatory hormone responses to various dietary proteins differ by body mass index status despite similar reductions in ad libitum energy intake. J Clin Endocrinol Metab 2006;91:2913-9.

21. Wurtman RJ, Wurtman JJ. Do carbohydrates affect food intake via neurotransmitter activity? Appetite 1988;11 Suppl 1:42-7.

22. Halford JC, Harrold JA, Boyland EJ, Lawton CL, Blundell JE. Serotonergic drugs : effects on appetite expression and use for the treatment of obesity. Drugs 2007;67:27-55.

23. Nieuwenhuizen AG, Hochstenbach-Waelen A, Veldhorst MA, et al. Acute effects of breakfasts containing alpha-lactalbumin, or gelatin with or without added tryptophan, on hunger, 'satiety' hormones and amino acid profiles. Br J Nutr 2008:1-8.

24. Harris JA, Benedict FG. A Biometric Study of Human Basal Metabolism. Proc Natl Acad Sci U S A 1918;4:370-3.

25. Simpson SJ, Raubenheimer D. Obesity: the protein leverage hypothesis. Obes Rev 2005;6:13342.

26. Dempster P, Aitkens S. A new air displacement method for the determination of human body composition. Med Sci Sports Exerc 1995;27:1692-7.

27. Westerterp KR, Wouters L, van Marken Lichtenbelt WD. The Maastricht protocol for the measurement of body composition and energy expenditure with labeled water. Obes Res 1995;3 Suppl 1:49-57.

28. siri W. Body composition from fluid spaces and density: analysis of methods. . In: Henschel A, ed. Techniques for Measuring Body Composition. Washington DC: Natl.Acad.Sci.Natl.Res.Council, 1961:223-224.

29. Philippaerts RM, Westerterp KR, Lefevre J. Doubly labelled water validation of three physical activity questionnaires. Int J Sports Med 1999;20:284-9.

30. Friedewald WT, Levy RI, Fredrickson DS. Estimation of the concentration of low-density lipoprotein cholesterol in plasma, without use of the preparative ultracentrifuge. Clin Chem 1972;18:499-502.

31. Westerterp KR, Meijer GA, Kester AD, Wouters L, ten Hoor F. Fat free mass as a function of fat mass and habitual activity level. Int J Sports Med 1992;13:163-6.

32. Phillips SM. Physiologic and molecular bases of muscle hypertrophy and atrophy: impact of resistance exercise on human skeletal muscle (protein and exercise dose effects). Appl Physiol Nutr Metab 2009;34:403-10.

33. Harber MP, Schenk S, Barkan AL, Horowitz JF. Effects of dietary carbohydrate restriction with high protein intake on protein metabolism and the somatotropic axis. J Clin Endocrinol Metab 2005;90:5175-81.

34. Paddon-Jones D, Sheffield-Moore M, Zhang XJ, et al. Amino acid ingestion improves muscle protein synthesis in the young and elderly. Am J Physiol Endocrinol Metab 2004;286:E321-8.

35. Tessari P, Kiwanuka E, Zanetti M, Barazzoni R. Postprandial body protein synthesis and amino acid catabolism measured with leucine and phenylalanine-tyrosine tracers. Am J Physiol Endocrinol Metab 2003;284:E1037-42.

36. van Milgen J. Modeling biochemical aspects of energy metabolism in mammals. J Nutr 2002;132:3195-202.

37. Lejeune MP, Kovacs EM, Westerterp Plantenga MS. Additional protein intake limits weight regain after weight loss in humans. Br J Nutr 2005;93:281-9.

38. Baba NH, Sawaya S, Torbay N, Habbal Z, Azar S, Hashim SA. High protein vs high carbohydrate hypoenergetic diet for the treatment of obese hyperinsulinemic subjects. Int J Obes Relat Metab Disord 1999;23:1202-6.

39. Due A, Toubro S, Skov AR, Astrup A. Effect of normal-fat diets, either medium or high in protein, on body weight in overweight subjects: a randomised 1-year trial. Int J Obes Relat Metab Disord 2004;28:1283-90.

40. Anderson GH, Tecimer SN, Shah D, Zafar TA. Protein source, quantity, and time of consumption determine the effect of proteins on short-term food intake in young men. J Nutr 2004;134:3011-5. 
41. Wolfe BM, Piche LA. Replacement of carbohydrate by protein in a conventional-fat diet reduces cholesterol and triglyceride concentrations in healthy normolipidemic subjects. Clin Invest Med 1999;22:140-8. 



\section{ELEVATED PROTEIN RECOMMENDED AND LOWERED CARBOHYDRATE ADDITIONALLY SUGGESTED FOR OPTIMAL WEIGHT LOSS}

StiJn Soenen, Alberto G Bonomi, Jolande Scholte,

MYRIAM AMA THIJSSEN, FRANK VAN BERKUM ANd Margriet S Westerterp-Plantenga

SUBMITTED FOR PUBLICATION 


\section{ABSTRACT}

\section{Objective}

Relatively high-protein diets as well as 'low-carb' diets have been shown to be effective in reduction of body weight and fat percentage. The present aim is to unravel whether it is elevated protein low carbohydrate during energy restriction that is crucial herein.

\section{Design}

Body weight and fat percentage (deuterium-dilution technique) of 139 participants $(107 \pm 20 \mathrm{~kg}$ and $44 \pm 6 \%)$ and blood- and urine-parameters were compared during 3 months between four $-67 \%$ energy-restriction diets, namely with energy percentages of protein/carbohydrate/fat: $30 / 35 / 35 \mathrm{E} \%$ sustained-protein normal-carbohydrate (SPNC), 30/5/65E\% sustained-protein low-carbohydrate (SPLC), 60/35/5E\% suprasustained-protein normal-carbohydrate (SSPNC), and 60/5/35E $\%$ supra-sustainedprotein low-carbohydrate (SSPLC). 24-hours nitrogen analyses showed protein intakes of $66 \pm 17 \mathrm{~g}$ (SPNC-diet), $72 \pm 19 \mathrm{~g}$ (SPLC-diet), 99 $\pm 26 \mathrm{~g}$ (SSPNC-diet), and $115 \pm 28 \mathrm{~g}$ (SSPLC-diet).

\section{Results}

Synergistically, the SSPLC-diet showed the largest decrease in body weight and fat percentage from 1 month onwards $(\mathrm{p}<0.05)$. The elevated-protein intake of the SSPdiets had not only an effect on body weight and fat percentage when combined with low- (SSPLC $-15 \pm 5 \mathrm{~kg}$ and $-6 \pm 3 \%$ vs. SPLC $-12 \pm 4 \mathrm{~kg}$ and $-5 \pm 4 \%, \mathrm{p}<0.05$ ) but also with normal-carbohydrate intake (SSPNC $-13 \pm 3 \mathrm{~kg}$ and $-6 \pm 3 \%$ vs. SPNC $-11 \pm 4 \mathrm{~kg}$ and $-4 \pm 3 \%, \mathrm{p}<0.05)$. The low-carbohydrate intake however had no effect on body weight and fat percentage when combined with the sustained-protein intake, yet only was effective in the presence of a supra-sustained-protein diet. The decrease in body weight improved the metabolic profile. Kidney function parameters did not change over time.

\section{Conclusion}

Elevated-protein plus lowered-carbohydrate diet reduce body weight and fat percentage synergistically most, followed by an elevated-protein diet irrespective of the carbohydrate content, while a lowered-carbohydrate diet only reduces body weight and fat percentage relatively more in the presence of an elevated-protein diet.

\section{Keywords}

high protein, low carb, weight loss, body composition 


\section{INTRODUCTION}

Obesity, one of the major health problems of today, develops due to an imbalance between energy intake and energy expenditure. Both energy intake and energy expenditure have been targeted to combat the development of increasing body weight and fat percentage. Reducing the excess of body weight and fat percentage can successfully be reached by restricting energy intake, supported by a balanced macronutrient composition of the diet. In this aspect, low carbohydrate energyrestricted diets have been shown to be more successful in the short-term compared to higher carbohydrate intakes (1-5). However, these energy-restricted diets did not only decrease the energy percentage of carbohydrate but also increased the energy percentage of protein of the diet compared to the control diet (1-5). Diets with energypercentages of 20 to $30 \%$ of protein during energy restriction of about $50 \%$, named 'high' protein energy restricted diets, actually sustain the absolute amount of required protein $(0.8 \mathrm{~g} / \mathrm{kg}$ body weight) during energy balance (energy-percentages of 10 to $15 \%$ of protein during weight-stable conditions). These diets resulted in relatively increased reduction of body weight and fat percentage as a result of a sustained level of satiety, relatively increased energy expenditure, increased fat oxidation and sparing of fat free mass (6-8). Regarding the optimal macronutrient composition of an energyrestricted diet, the question remains whether it is the decrease in carbohydrate or the increase in protein content that is crucial in the larger reduction of body weight and fat percentage. Therefore, the aim of this study was to compare possible differences in reduction of body weight and fat percentage as a result of $-67 \%$ restricted energy intake of four diets contrasting elevated vs. normal protein and/or lowered vs. normal carbohydrate intake.

\section{METHODS}

The study was conducted following a randomized $2 \times 2$ factorial design including 4 parallel energy-restriction diets differing in protein and/or carbohydrate content, namely sustained-protein normal-carbohydrate (SPNC), sustained-protein lowcarbohydrate (SPLC), supra-sustained-protein normal-carbohydrate (SSPNC), and supra-sustained-protein low-carbohydrate (SSPLC). The Medical Ethics committee of the University Medical Centre Groningen approved the study. The study is registered in www.clinicaltrials.gov, number NCT00862953. All participants gave written informed consent.

\section{Participants}

Participants were recruited from potential clients of a weight management program of an outpatient-clinic in the city of Hengelo, The Netherlands. These subjects were referred by their general practitioner or specialist, or came on their own initiative. A dietitian explained the study-protocol orally and handed-out a paper version. Inclusion criteria were age $18-80$ years and BMI $>27 \mathrm{~kg} / \mathrm{m}^{2}$. Exclusion criteria were underlying malignity, cancer, HIV-infection, psychiatric disease, more than $10 \%$ reduction of body weight during the last 6 months; moreover women who were pregnant or breastfeeding were excluded. From the 139 participants who started, only $4 \%$ droppedout; 2 in the SPNC-group after 1 week, 1 in the SPLC-group after 6 weeks, 2 in the 


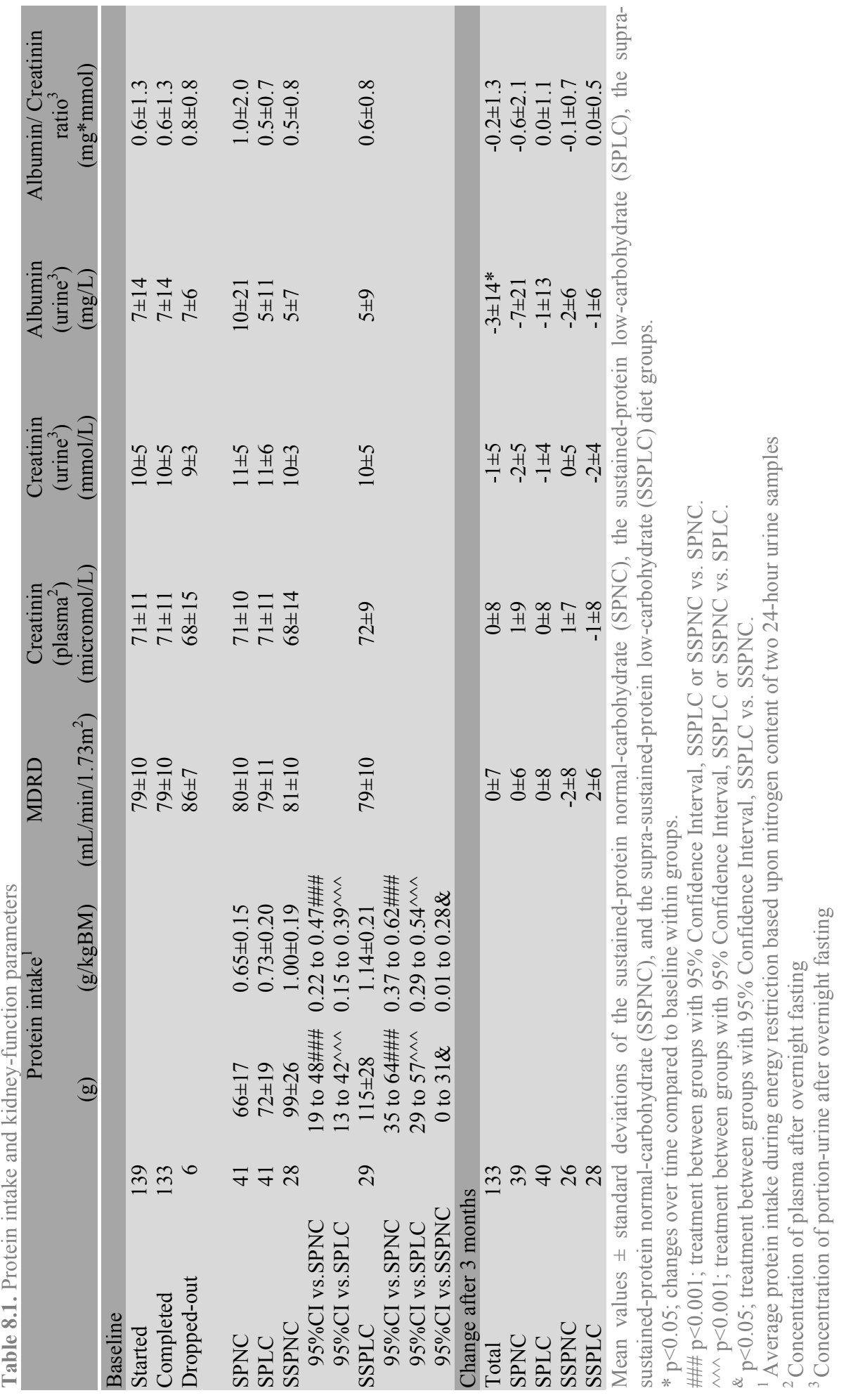


SSPNC-group after 1 and 8 weeks, and 1 in the SSPLC-group after 8 weeks. Participants stopped due to several reasons, such as personal reasons and inability to fulfill the schedule with visits to the clinic.

\section{Dietary intervention}

Prescribed dietary intake was restricted with $67 \%$ for 3 months after a run-in phase of 2 weeks with energy intake of $100 \%$. Prescribed energy intake was calculated for each participant individually based upon the equation of Harris-Benedict for estimation of basal metabolic rate, and multiplied by a Physical Activity Index (PAL) of 1.5 for total energy expenditure. The diets had the following macronutrient composition of energy percent of protein/carbohydrate/fat: SPNC 10/50/40, SPLC 10/25/65, SSPNC 20/50/30 and SSPLC 20/25/55 during the run-in phase, and SPNC 30/35/35, SPLC 30/5/65, SSPNC 60/35/5 and SSPLC 60/5/35 during the energy-restricted phase. Baseline protein intake of the run-in phase was kept constant in grams during the energyrestricted phase to ensure sufficient protein availability for the preservation of fat free mass.

\section{Counseling}

Participants followed a standardized group-organized program, guided by dietitians and containing participants from all diet-groups. The program focused on eating behavior and healthy diet. Diets were supplemented, if necessary, with whey-protein milkshakes (Ollyxa, The Netherlands) to reach the prescribed protein content of the diet. Participants visited the clinic every week in the first month and every 2 weeks in the following 2 months, in total 9 sessions over the 3 months.

\section{Measurements}

At the clinic, body weight was measured at all visits. Subjects were weighed in their underwear after an overnight fast, using a calibrated hospital scale to the nearest $0.1 \mathrm{~kg}$ (Tanita TBF-310). Height was measured at screening to the nearest $0.1 \mathrm{~cm}$ (Secastadiometer). Waist circumference was measured each month at the site of smallest circumference between rib cage and iliac crest and hip circumference was measured at the site of largest circumference between waist and thighs. Systolic and diastolic blood pressures were recorded each month using an automatic blood pressure monitor with subjects in sitting position (Microlife BP 3AC1-2).

Body composition was assessed at baseline and after 3 months with the deuteriumdilution technique (9). The dilution of the deuterium isotope $\left({ }^{2} \mathrm{H}_{2} \mathrm{O}\right)$ is a measure for total body water. Fat free mass was calculated by dividing total body water by the hydrating factor 0.73 .

To determine physical activity the validated Baecke-questionnaire was used. Furthermore, a motion sensor was used to measure physical activity for 14 consecutive days in a subgroup of 52 participants. The device was a tri-axial validated Tracmoraccelerometer (Philips Research) (10). Participants were instructed to place the accelerometer at the lower back and to wear it during waking hours. Physical activity was quantified by defining the average acceleration counts scored daily. 
To determine whether attitudes towards food intake changed during the experiment, a validated Dutch translation of the Three Factor Eating Questionnaire (TFEQ) was used.

Fasting venous blood samples were taken at baseline and after 3 months to analyze concentrations of plasma insulin, glucose, creatinin, TAG, HDL, LDL and total cholesterol, and concentrations of albumin and creatinin in urine samples. Furthermore, 24-hour urine nitrogen content was determined. Participants were thoroughly instructed to collect all urine excreted after the first volume voided in the morning until and including the first morning urine voided the following day. Urine samples were collected in containers with $10 \mathrm{~mL} \mathrm{H}_{2} \mathrm{SO}_{4}$ to prevent nitrogen loss through evaporation. Volume and nitrogen concentration were measured, the latter with a nitrogen analyzer (CHN-O-Rapid; Heraeus, Hanau, Germany). Plasma was obtained by centrifugation $\left(1500^{*} \mathrm{~g}\right.$ for $10 \mathrm{~min}$ at $4^{\circ} \mathrm{C}$ ), frozen in liquid nitrogen and stored at $-80^{\circ} \mathrm{C}$ until analysis. Insulin was measured using an immuno-metrical chemo-luminescention assay on an Immulite 2000 analyzer (Siemens Medical Solutions Diagnostics). Albumin, creatinin, glucose, TAG, HDL and total cholesterol were measured using a standardized enzymatic colorimetric method on the Cobas 6000 analyzer (Roche Diagnostics). LDL cholesterol was calculated according to the Friedewald formula. HOMA-index was calculated by glucose $(\mathrm{mmol} / \mathrm{L}) *$ insulin $(\mathrm{mUnits} / \mathrm{L}) / 22.5$.

\section{Statistical analysis}

Data are presented as means with standard deviations unless otherwise stated. Differences between groups were tested by ANCOVA with baseline values as covariate. Changes over time between and within groups were tested by factorial repeated-measures ANOVA with Bonferroni post hoc corrections. Analyses were intention to treat analyses with no substitution of the missing values because of the low number of dropouts, i.e. $4 \%$. Differences were regarded as significant if $p<0.05$. All analyses were performed with the Statistical Package for the Social Sciences (SPSS) version 16.0.2 for Macintosh OS X.

\section{RESULTS}

Protein intake was higher in the supra-sustained-protein diets compared to the sustained-protein diets $(\mathrm{p}<0.05$, Table 8.1). Kidney-function parameters did not change over time and were not different between diet-groups.

\section{Body weight}

Body weight reduced significantly in all groups $(\mathrm{p}<0.001$, Table 8.2$)$. The reduction of body weight was most effective in the SSPLC-diet; this reduction was significantly more compared to both SP-diets $(\mathrm{p}<0.01$, Figure 8.1$)$. So, there was a synergistic effect of supra-sustained-protein and low-carbohydrate (SSPLC vs. SPNC) and an effect of supra-sustained-protein in the low-carbohydrate condition (SSPLC vs. SPLC). Furthermore, there was an effect of supra-sustained-protein in the normal-carbohydrate condition (SSPNC vs. SPNC, $\mathrm{p}<0.05$ ). There was no effect of low-carbohydrate in the sustained- (SPLC vs. SPNC) or supra-sustained-protein (SSPLC vs. SSPNC) condition. Overall, reduction of body weight was related to absolute protein intake $(r=-0.306$, $\mathrm{p}<0.001$ ). 


\section{Body composition}

Fat percentage, fat mass, fat free mass, and waist- and hip-circumference decreased in all groups $(\mathrm{p}<0.001$, Table 8.2). Fat percentage and fat mass decreased most effectively in the SSPLC-diet. The effect of elevated protein on fat mass reduction was significant in the normal- (SSPNC vs. SPNC) and low-carbohydrate (SSPLC vs. SPLC) condition $(\mathrm{p}<0.05)$, and thus independent of carbohydrate condition, while no effect of low-carbohydrate in the sustained- (SPLC vs. SPNC) or supra-sustainedprotein (SSPLC vs. SSPNC) condition occurred. Change in fat free mass was not different between groups.

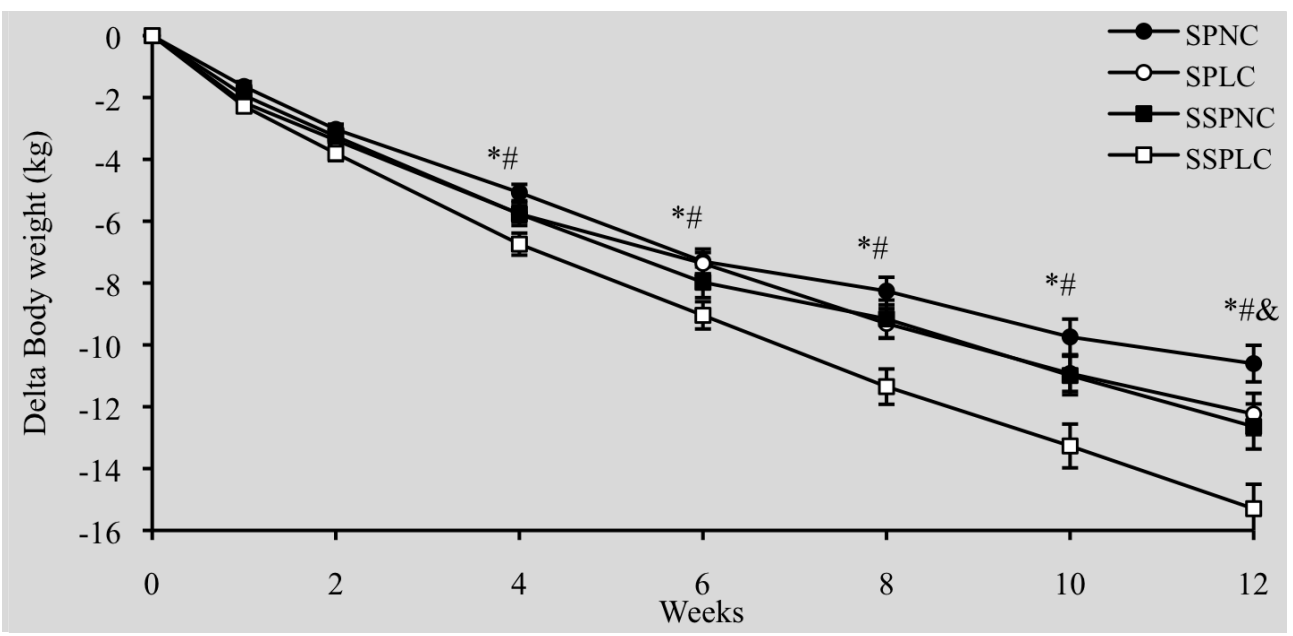

Figure 8.1. Means and SEM of reduction of body weight of the 3-months of energy restriction of the sustained-protein normal-carbohydrate (SPNC), the sustained-protein low-carbohydrate (SPLC), the supra-sustained-protein normal-carbohydrate (SSPNC), and the supra-sustained-protein lowcarbohydrate (SPLC) diet group.

$* \mathrm{p}<0.01$, treatment over time between groups, higher decease in body weight of SSPLC vs. SPNC of $-1.2,-1.5,-2.2,-2.7$ and 3.6 with $95 \%$ Confidence Intervals

of -2.0 to $-0.5,-2.6$ to $-0.4,-3.5$ to $-0.9,-4.3$ to -1.2 and -5.2 to -1.9

after $4,6,8,10$ and 12 weeks of energy restriction.

$\# \mathrm{p}<0.05$, treatment over time between groups, higher decease in body weight of SSPLC vs. SPLC of $-0.9,-1.4,-1.6,-1.9$ and 2.3 with $95 \%$ Confidence Intervals

of -1.6 to $-0.1,-2.4$ to $-0.4,-2.9$ to $-0.4,-3.3$ to -0.4 and -4.0 to -0.7

after $4,6,8,10$ and 12 weeks of energy restriction.

$\& \mathrm{p}<0.05$, treatment over time between groups, higher decease in body weight of SSPNC vs. SPNC of -2.2 with $95 \%$ Confidence Interval of -3.9 to -0.5 after 12 weeks of energy restriction.

\section{Metabolic profile}

Blood pressure, heart rate and fasting plasma concentrations of glucose, insulin, HOMA-index, TAG and total cholesterol decreased after the 3 months of energy restriction $(\mathrm{p}<0.01$, Table 8.3). Groups did not differ in changes in glucose, insulin, HOMA-index, TAG, HDL, LDL and total cholesterol. The decrease in insulin $(\mathrm{r}=0.311, \mathrm{p}<0.001)$ and HOMA-index $(\mathrm{r}=0.307, \mathrm{p}<0.001)$ were related to decrease in body weight. Decreases in insulin $(\mathrm{r}=0.239, \mathrm{p}=0.007)$, HOMA-index $(\mathrm{r}=0.187$, 


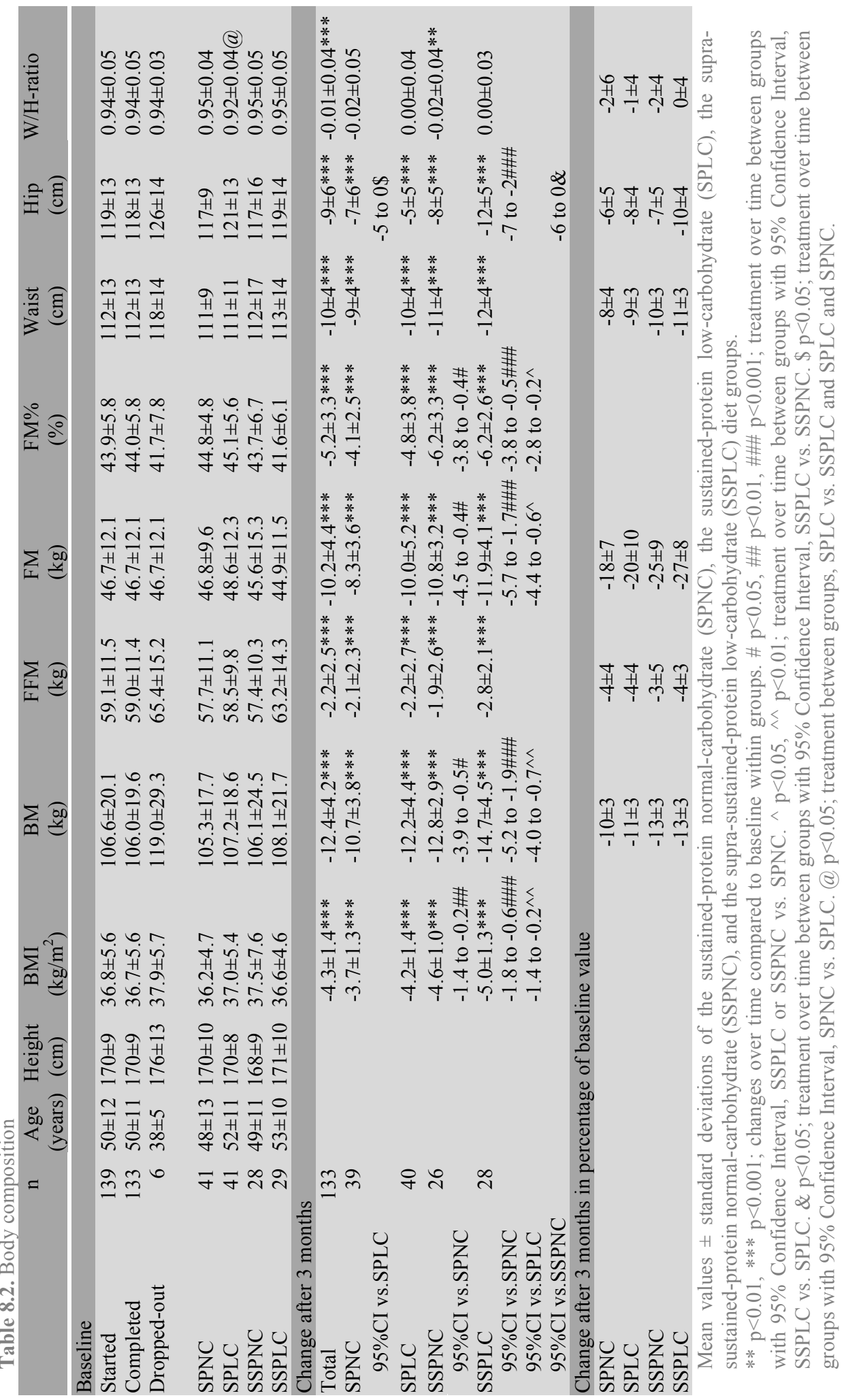




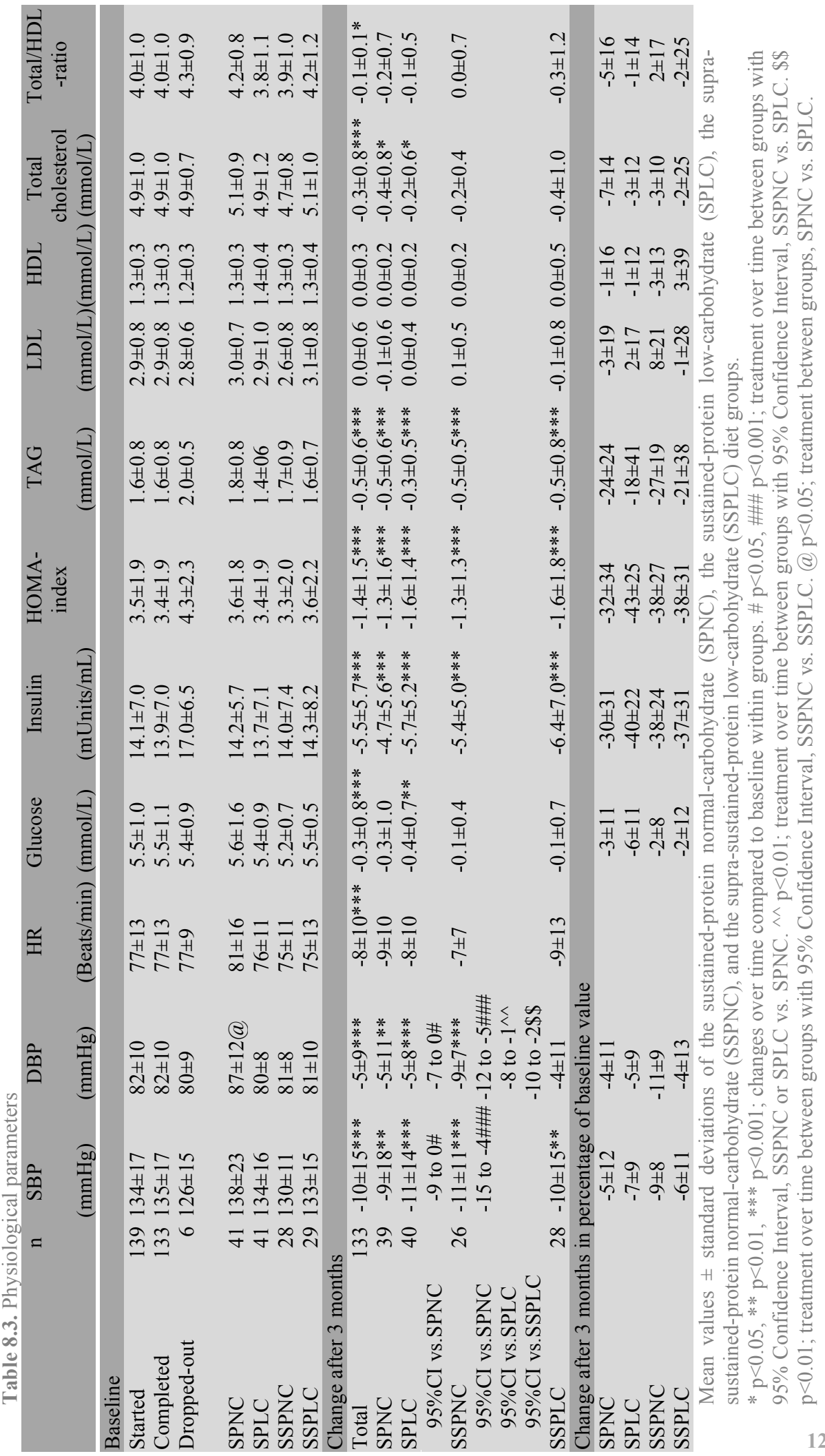




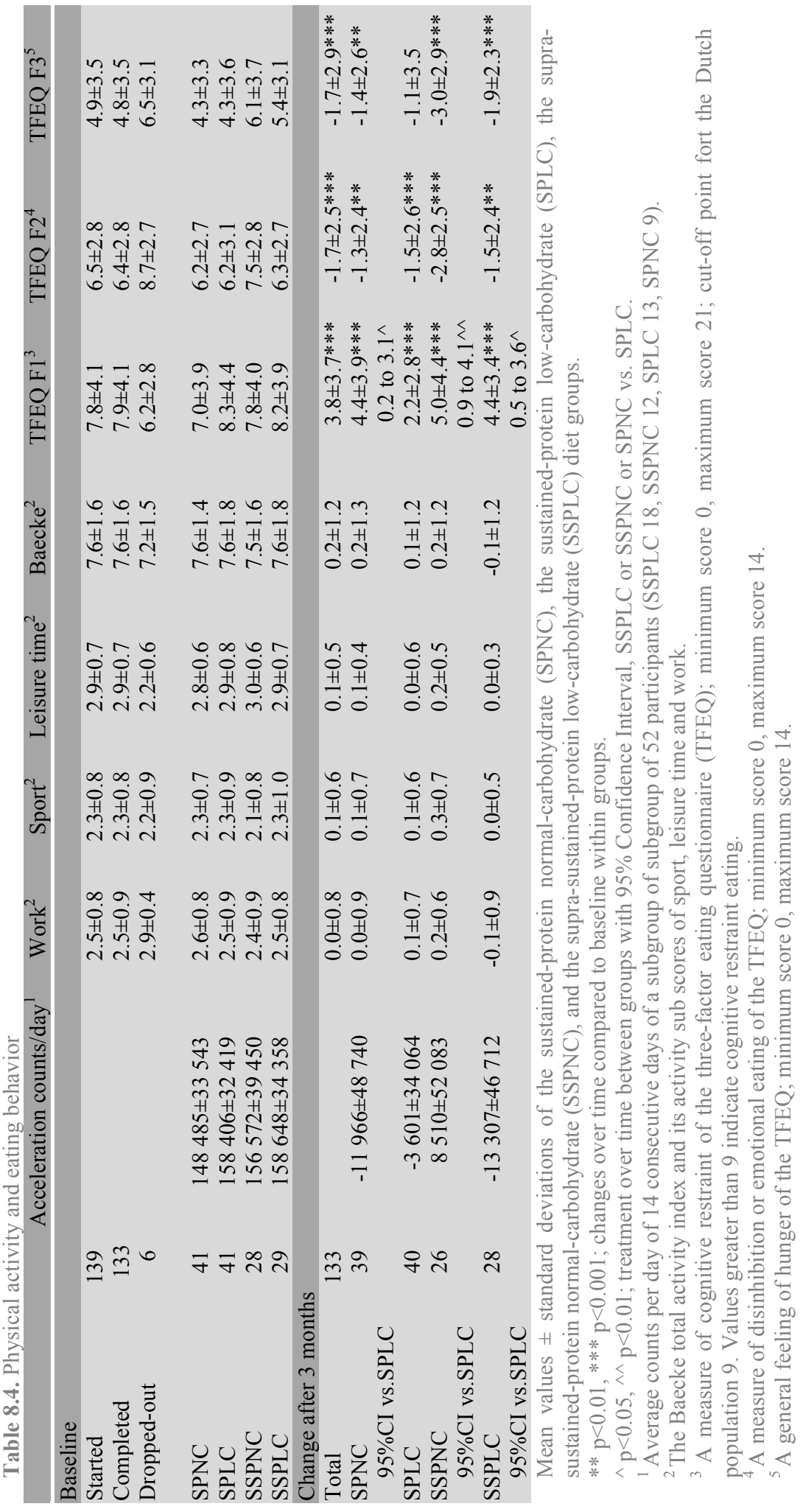


$\mathrm{p}=0.030)$, and systolic $(\mathrm{r}=0.195, \mathrm{p}=0.030)$ and diastolic blood pressure $(\mathrm{r}=0.261$, $\mathrm{p}=0.003$ ) were related to the decrease in waist circumference.

\section{Physical activity and eating behavior}

Groups did not differ in changes in physical activity, measured with the Baecke questionnaire; nor did a subgroup, measured with the Tracmor-accelerometer (Table 8.4). TFEQ-scores of dietary restraint (F1) increased, and scores of disinhibition (F2) and hunger (F3) decreased after the 3 months of energy restriction $(\mathrm{p}<0.01)$. The restraint score increased significantly less in the SPLC-diet compared to all 3 other diets $(p<0.05)$. The decreases in body weight and waist circumference were related to the decrease in disinhibition score $(r=0.226, p=0.010 ; r=0.206, p=0.020)$. Furthermore, the decrease in body weight was related to the decrease in hunger score $(\mathrm{r}=0.291, \mathrm{p}<0.001)$. Restraint score was a function of disinhibition score $(\mathrm{r}=-0.382, \mathrm{p}<0.001)$ and hunger score $(\mathrm{r}=-0.344, \mathrm{p}<0.001)$; disinhibition score was a function of hunger score $(\mathrm{r}=0.526, \mathrm{p}<0.001)$.

\section{DISCUSSION}

Synergistically, the supra-sustained-protein and low-carbohydrate diet showed the largest decrease in body weight and fat percentage. The elevated protein intake of the supra-sustained-protein diet had not only an effect on body weight and fat percentage when combined with low-carbohydrate but also when combined with normalcarbohydrate intake. The low-carbohydrate intake however had no effect on body weight and fat percentage when combined with the sustained-protein intake, yet only was effective in the presence of a supra-sustained-protein diet. Thus the effect of elevated protein on body weight reduction was reinforced in the presence of lowcarbohydrate intake; not only the combination was most effective, supra-sustained vs. sustained-protein intake reached level of significance after already 4 weeks in the lowcarbohydrate condition compared to after 12 weeks in the normal-carbohydrate condition.

Elevated protein and lowered carbohydrate intake also resulted previously in larger reduction of body weight compared to elevated protein and normal carbohydrate intake after energy restriction for 4 weeks (11). Energy restriction of 2 up to 6 months showed a larger reduction of body weight of elevated protein intake in combination with normal $(8,12,13)$ or lowered $(1-4,6,14-17)$ carbohydrate intake compared to control diets. Oppositely, one very large study found no difference in loss of body weight between diets with different macronutrient compositions (18). However, in that study elevation in protein intake was estimated to be minor, i.e. less than 5\%. Our protocol was successful in creating a contrast in protein intake between the supra-sustained- and sustained-protein diets (1.1 vs. $0.7 \mathrm{~g} / \mathrm{kg}$ body weight). By using 24-hour urine nitrogen content to quantify protein intakes, we calculated the absolute grams of protein intake in reality and thereby confirmed the presence and magnitude of intervention over 3 months. This is the only and necessary way to show compliance to protein intake, as it is well known that dietary record methods are prone to misreporting (19).

Larger reduction of body weight and fat percentage relates to an elevated proteininduced satiety, elevated energy expenditure and in particular elevated fat oxidation, and sparing of fat free mass. In studies with an ad libitum food intake approach, 
elevated protein intake led to a decrease in body weight $(8,20)$, supported by a higher level of satiety of proteins compared to carbohydrates and fat $(7,8)$. Elevated-protein intake therefore can increase the compliance to a prescribed energy-restricted diet resulting into successful reduction of body weight over time $(6,7,12)$. In our study with prescribed diets, the overall decrease in body weight and/or waist circumference were related to decrease in subjective feeling of hunger and decrease in disinhibition, while hunger, disinhibition and restraint were inter-related. Thus, increase in restraint with decrease in hunger and decrease in disinhibition reinforce good compliance to the diet resulting in successful reduction of body weight over time.

An additional mechanism underscoring the decrease in body weight of the elevated-protein, low-carbohydrate, relatively high fat diet is the very strong satietyeffect created by the ketogenic state of the diet. The formation of ketone bodies such as beta-hydroxybutyrate (21) are related to appetite-reduction and greater reduction of body weight in humans when they are energy restricted $(5,11,22)$. Moreover, this type of diet increases energy expenditure, supporting a negative energy balane, via increased gluconeogenesis (25).

The sustained-protein low-carbohydrate diet did not differ in reduction of body weight or fat percentage compared to the sustained-protein normal-carbohydrate diet. This may be explained by the significantly lower increase in restraint score and lack of decrease in subjective feeling of hunger compared to all 3 other diets resulting into a lower compliance to the diet in this group. Thus, carbohydrate to fat ratio only seems to influence body-weight loss during energy restriction in the presence of supra-sustained protein intake of $1.1 \mathrm{~g} / \mathrm{kg}$ body weight and not in the presence of sustained protein intake of $0.7 \mathrm{~g} / \mathrm{kg}$ body weight.

Studies measuring energy expenditure after food intake showed that proteins have a higher thermogenic response compared to carbohydrates and fat (26), resulting in increased 24-hour energy expenditure (27). The elevated energy expenditure was able to facilitate the reduction of body weight as the energy expenditure is sustained despite this body weight-reduction (28), thus preventing the 'yo-yo-effect'. In addition, elevated protein intake changes substrate oxidation, in that more fat is oxidized than consumed resulting in a negative fat balance, thereby facilitating the reduction of fat mass $(29,30)$.

During elevated protein intake less protein is oxidized than consumed resulting in a positive protein balance (29). As muscle protein synthesis is greatly influenced by systemic amino acid availability (31) nitrogen retention results into net muscle protein synthesis (32). Indeed, elevated protein intakes of $1.0-1.5 \mathrm{~g} / \mathrm{kg}$ body weight results in sparing of fat free mass during reduction of body weight after energy restriction $(7,12$, $33,34)$. This preservation of fat free mass is crucial, as it is the main determinant of resting metabolic rate (35), and thereby supports the negative energy balance (energy intake - energy expenditure) during energy restriction. As body weight decreased more for the supra-sustained-protein diets but fat free mass decreased the same for all diets, these diets with elevated protein intake succeeded more in preserving fat free mass during the loss of body weight. The greater reduction of fat mass and preservation of fat free mass of the supra-sustained-protein energy-restriction diets promoted a higher ratio of fat free mass to fat mass and thus lower fat percentage. 
The metabolic profile was remarkably improved in all groups. The decreased metabolic parameters were related to the decrease in waist and body weight, thereby showing completely the beneficial effect of reduction of body weight and regional fat depots. Glucose, insulin, HOMA-index, TAG and total cholesterol decreased as a result of the dietary intervention, as was also shown previously $(12,36)$.

Regarding these protein rich diets, some caution is needed when protein intake is elevated in an absolute sense for a longer period. There may be adverse effects on the kidney, related to elevated blood pressure. Our dietary intervention did not affect kidney function parameters and resulted in a decrease in systolic and diastolic blood pressure after the reduction of body weight. Individuals with sub-clinical renal functioning due to metabolic syndrome or diabetes mellitus type 2, and elderly are especially vulnerable (37). However, the link between protein intake and the initiation or progression of renal disease lacks evidence in healthy individuals $(30,38)$. Furthermore, consumption of alkali-rich foods like fruits and vegetables buffering acidic loads (39) was strongly advised in all diets.

In conclusion, elevated-protein plus lowered-carbohydrate diet during energy restriction reduce body weight and fat percentage synergistically most, followed by elevated-protein diet irrespective of the carbohydrate content, while a lowcarbohydrate diet only reduces body weight and fat percentage more in the presence of elevated-protein diet.

\section{ACKNOWLEDGEMENTS}

We gratefully acknowledge collaboration with Previtas, Annemieke Izeboud, WillemJan Toubes and Bruce Wolffenbuttel. The study was supported by Top Institute Food and Nutrition (TIFN, Wageningen, The Netherlands). 


\section{REFERENCES}

1. Gardner CD, Kiazand A, Alhassan S, et al. Comparison of the Atkins, Zone, Ornish, and LEARN diets for change in weight and related risk factors among overweight premenopausal women: the A TO Z Weight Loss Study: a randomized trial. Jama 2007;297:969-77.

2. Boden G, Sargrad K, Homko C, Mozzoli M, Stein TP. Effect of a low-carbohydrate diet on appetite, blood glucose levels, and insulin resistance in obese patients with type 2 diabetes. Ann Intern Med 2005;142:403-11.

3. Dansinger ML, Gleason JA, Griffith JL, Selker HP, Schaefer EJ. Comparison of the Atkins, Ornish, Weight Watchers, and Zone diets for weight loss and heart disease risk reduction: a randomized trial. Jama 2005;293:43-53.

4. Foster GD, Wyatt HR, Hill JO, et al. A randomized trial of a low-carbohydrate diet for obesity. N Engl J Med 2003;348:2082-90.

5. Samaha FF, Iqbal N, Seshadri P, et al. A low-carbohydrate as compared with a low-fat diet in severe obesity. N Engl J Med 2003;348:2074-81.

6. Krieger JW, Sitren HS, Daniels MJ, Langkamp-Henken B. Effects of variation in protein and carbohydrate intake on body mass and composition during energy restriction: a meta-regression 1. Am J Clin Nutr 2006;83:260-74.

7. Lejeune MP, Kovacs EM, Westerterp-Plantenga MS. Additional protein intake limits weight regain after weight loss in humans. Br J Nutr 2005;93:281-9.

8. Weigle DS, Breen PA, Matthys CC, et al. A high-protein diet induces sustained reductions in appetite, ad libitum caloric intake, and body weight despite compensatory changes in diurnal plasma leptin and ghrelin concentrations. Am J Clin Nutr 2005;82:41-8.

9. Westerterp KR, Wouters L, van Marken Lichtenbelt WD. The Maastricht protocol for the measurement of body composition and energy expenditure with labeled water. Obes Res 1995;3 Suppl 1:49-57.

10. Plasqui G, Joosen AM, Kester AD, Goris AH, Westerterp KR. Measuring free-living energy expenditure and physical activity with triaxial accelerometry. Obes Res 2005;13:1363-9.

11. Johnstone AM, Horgan GW, Murison SD, Bremner DM, Lobley GE. Effects of a high-protein ketogenic diet on hunger, appetite, and weight loss in obese men feeding ad libitum. Am J Clin Nutr 2008;87:44-55.

12. Noakes M, Keogh JB, Foster PR, Clifton PM. Effect of an energy-restricted, high-protein, lowfat diet relative to a conventional high-carbohydrate, low-fat diet on weight loss, body composition, nutritional status, and markers of cardiovascular health in obese women. Am J Clin Nutr 2005;81:1298-306.

13. Layman DK, Boileau RA, Erickson DJ, et al. A reduced ratio of dietary carbohydrate to protein improves body composition and blood lipid profiles during weight loss in adult women. J Nutr 2003;133:411-7.

14. Shai I, Schwarzfuchs D, Henkin Y, et al. Weight loss with a low-carbohydrate, Mediterranean, or low-fat diet. N Engl J Med 2008;359:229-41.

15. Yancy WS, Jr., Olsen MK, Guyton JR, Bakst RP, Westman EC. A low-carbohydrate, ketogenic diet versus a low-fat diet to treat obesity and hyperlipidemia: a randomized, controlled trial. Ann Intern Med 2004;140:769-77.

16. Sondike SB, Copperman N, Jacobson MS. Effects of a low-carbohydrate diet on weight loss and cardiovascular risk factor in overweight adolescents. J Pediatr 2003;142:253-8.

17. Westman EC, Yancy WS, Edman JS, Tomlin KF, Perkins CE. Effect of 6-month adherence to a very low carbohydrate diet program. Am J Med 2002;113:30-6.

18. Sacks FM, Bray GA, Carey VJ, et al. Comparison of weight-loss diets with different compositions of fat, protein, and carbohydrates. N Engl J Med 2009;360:859-73.

19. Westerterp KR, Goris AH. Validity of the assessment of dietary intake: problems of misreporting. Curr Opin Clin Nutr Metab Care 2002;5:489-93.

20. Due A, Toubro S, Skov AR, Astrup A. Effect of normal-fat diets, either medium or high in protein, on body weight in overweight subjects: a randomised 1-year trial. Int J Obes Relat Metab Disord 2004;28:1283-90. 
21. Langhans W. Fatty acid oxidation in the energostatic control of eating--a new idea. Appetite 2008;51:446-51.

22. Kahler A, Zimmermann M, Langhans W. Suppression of hepatic fatty acid oxidation and food intake in men. Nutrition 1999;15:819-28.

23. Robinson AM, Williamson DH. Physiological roles of ketone bodies as substrates and signals in mammalian tissues. Physiol Rev 1980;60:143-87.

24. Scharrer E. Control of food intake by fatty acid oxidation and ketogenesis. Nutrition 1999;15:704-14.

25. Westerterp-Plantenga MS, Rolland V, Wilson SA, Westerterp KR. Satiety related to $24 \mathrm{~h}$ diet induced thermogenesis during high protein/carbohydrate vs high fat diets measured in a respiration chamber. Eur J Clin Nutr 1999;53:495-502.

26. Dauncey MJ, Bingham SA. Dependence of $24 \mathrm{~h}$ energy expenditure in man on the composition of the nutrient intake. Br J Nutr 1983;50:1-13.

27. Luscombe-Marsh ND, Noakes M, Wittert GA, Keogh JB, Foster P, Clifton PM. Carbohydraterestricted diets high in either monounsaturated fat or protein are equally effective at promoting fat loss and improving blood lipids. Am J Clin Nutr 2005;81:762-72.

28. Lejeune MP, Westerterp KR, Adam TC, Luscombe-Marsh ND, Westerterp-Plantenga MS. Ghrelin and glucagon-like peptide 1 concentrations, 24-h satiety, and energy and substrate metabolism during a high-protein diet and measured in a respiration chamber. Am J Clin Nutr 2006;83:89-94.

29. Halton TL, Hu FB. The effects of high-protein diets on thermogenesis, satiety and weight loss: a critical review. J Am Coll Nutr 2004;23:373-85.

30. Paddon-Jones D, Sheffield-Moore M, Zhang XJ, et al. Amino acid ingestion improves muscle protein synthesis in the young and elderly. Am J Physiol Endocrinol Metab 2004;286:E321-8.

31. Harber MP, Schenk S, Barkan AL, Horowitz JF. Effects of dietary carbohydrate restriction with high protein intake on protein metabolism and the somatotropic axis. J Clin Endocrinol Metab 2005;90:5175-81.

32. Farnsworth E, Luscombe ND, Noakes M, Wittert G, Argyiou E, Clifton PM. Effect of a highprotein, energy-restricted diet on body composition, glycemic control, and lipid concentrations in overweight and obese hyperinsulinemic men and women. Am J Clin Nutr 2003;78:31-9.

33. Piatti PM, Monti F, Fermo I, et al. Hypocaloric high-protein diet improves glucose oxidation and spares lean body mass: comparison to hypocaloric high-carbohydrate diet. Metabolism 1994;43:1481-7.

34. Halliday D, Hesp R, Stalley SF, Warwick P, Altman DG, Garrow JS. Resting metabolic rate, weight, surface area and body composition in obese women. Int J Obes 1979;3:1-6.

35. Wolfe BM, Piche LA. Replacement of carbohydrate by protein in a conventional-fat diet reduces cholesterol and triglyceride concentrations in healthy normolipidemic subjects. Clin Invest Med 1999;22:140-8.

36. Hoy WE, Hughson MD, Bertram JF, Douglas-Denton R, Amann K. Nephron number, hypertension, renal disease, and renal failure. J Am Soc Nephrol 2005;16:2557-64.

37. Martin WF, Armstrong LE, Rodriguez NR. Dietary-protein intake and renal function. Nutr Metab (Lond) 2005;2:25.

38. Barzel US, Massey LK. Excess dietary protein can adversely affect bone. J Nutr 1998;128:10513. 



\section{EFFECT OF CARBOHYDRATE CONTENT}

\section{OF PROTEIN LEVERAGE DIETS ON EFFICACY OF}

WEIGHT MAINTENANCE UPON WEIGHT LOSS

StiJn Soenen, Jolande Scholte, Myriam AMA ThiJsSen,

FRANK VAN BERKUM AND MARGRIET S WESTERTERP-PLANTENGA

SUBMITTED FOR PUBLICATION 


\section{ABSTRACT}

\section{Objective}

The objective was to examine whether it is sustained elevated protein or lowered carbohydrate during weight maintenance after energy restriction that is effective in reduction of body weight.

\section{Design}

Body weight (BM) and fat percentage (deuterium-dilution technique) of 139 participants $(107 \pm 20 \mathrm{~kg}$ and $44 \pm 6 \%)$ and blood- and urine-parameters were compared during 9 months of weight maintenance after 3 months of weight loss between four diets, with energy percentages of protein/carbohydrate/fat: 15/45/40E\% sustainedprotein normal-carbohydrate (SPNC), 15/25/60E\% sustained-protein low-carbohydrate (SPLC), 30/45/25\% supra-sustained-protein normal-carbohydrate (SSPNC), and 30/25/45E\% supra-sustained-protein low-carbohydrate (SSPLC) during weight maintenance. 24-hours nitrogen analyses showed protein intakes of $0.8 \pm 0.2 \mathrm{~g} / \mathrm{kgBM}$ (SPNC-diet), $0.8 \pm 0.2 \mathrm{~g} / \mathrm{kgBM}$ (SPLC-diet), $1.1 \pm 0.1 \mathrm{~g} / \mathrm{kgBM}$ (SSPNC-diet), and $1.2 \pm 0.2 \mathrm{~g} / \mathrm{kgBM}$ (SSPLC-diet) during the 12 months.

\section{Results}

The SSPNC-diet was the only diet that did not slightly regain in body weight and fat mass over the 9 months of weight maintenance after successful weight loss in all groups. The body-weight lost was preserved during the first 6 months of weight maintenance in all groups. Overall, the SSP-diets resulted in significantly larger decrease in body weight after the 12 months of dietary intervention. This weight loss was underscored by a decreased subjective feeling of hunger. Blood pressure, HOMAindex and fasting plasma concentrations of insulin also stayed decreased after 12 months. Furthermore, the low vs. normal carbohydrate intake reinforced the decrease in insulin and HOMA-index.

\section{Conclusion}

Elevated-protein plus normal-carbohydrate diet is most effective in maintaining reduced body weight, followed by the limiting effect on weight regain of elevated protein diets irrespective of the carbohydrate content.

\section{Keywords}

protein leverage, weight maintenance, body composition, metabolic profile 


\section{INTRODUCTION}

Excess of body weight and fat mass of obesity can successfully be targeted by energyrestricted diets. However, weight regain thereafter is a common problem that still needs attention (1). Oppositely to the traditional attention to fat and carbohydrate, the protein leverage hypothesis of Simpson (2) provides a mechanism for why protein intake is more important than fat or carbohydrate in diet regimes to promote and maintain bodyweight loss. Evidence suggests that macronutrient intake is regulated over a day. In contrast, energy balance is regulated over a few days to a week. Furthermore, the response of an unbalanced diet, relative to the usual daily intake target, is to prioritize protein intake. Individuals overeat carbohydrate and fat of a diet containing a lower ratio of protein to carbohydrate and fat until the daily intake target amount of protein is ingested, and not the target of total energy intake, where there would still be a deficit of protein intake (2). Elevated protein intake during energy restriction results in increased reduction of body weight and fat percentage as a result of sustained level of satiety reducing energy intake, of increased energy expenditure, and of sparing of fat free mass (3-5). Elevated protein intake combined with low carbohydrate intake can furthermore increase the rate of success of reducing body weight (6-10). Moreover, a protein intake of $1.2 \mathrm{~g} / \mathrm{kg}$ body weight in combination with low-carbohydrate intake showed the largest decrease in body weight after 3 months of energy restriction. As a follow up, the question remains whether this beneficial decrease in body weight can be maintained during weight maintenance. Therefore, the aim of this study was to compare possible differences in weight maintenance after reduction of body weight of four diets contrasting elevated vs. normal protein and/or lowered vs. normal carbohydrate intake.

\section{METHODS}

The study was conducted following a randomized $2 \times 2$ factorial design differing in protein and/or carbohydrate content, namely sustained-protein normal-carbohydrate (SPNC), sustained-protein low-carbohydrate (SPLC), supra-sustained-protein normalcarbohydrate (SSPNC), and supra-sustained-protein low-carbohydrate (SSPLC). The Medical Ethics committee of the University Medical Centre Groningen approved the study. The study is registered in www.clinicaltrials.gov, number NCT00862953. All participants gave written informed consent.

\section{Participants}

Participants were recruited from potential clients of a weight management program of an outpatient-clinic in the city of Hengelo, The Netherlands. These subjects were referred by their general practitioner or specialist, or came on their own initiative. A dietitian explained the study-protocol orally and handed-out a paper version. Inclusion criteria were age $18-80$ years and BMI $>27 \mathrm{~kg} / \mathrm{m}^{2}$. Exclusion criteria were underlying malignity, cancer, HIV-infection, psychiatric disease, more than $10 \%$ reduction of body weight during the last 6 months, moreover women who were pregnant or breastfeeding were excluded. From the 139 participants who started, 37 dropped-out during the 12 months; 14 in the SPNC-group (2 during the 3 months of $33 \%$ energy intake +12 during the following 9 months of $67 \%$ energy intake), 11 in the SPLC- 


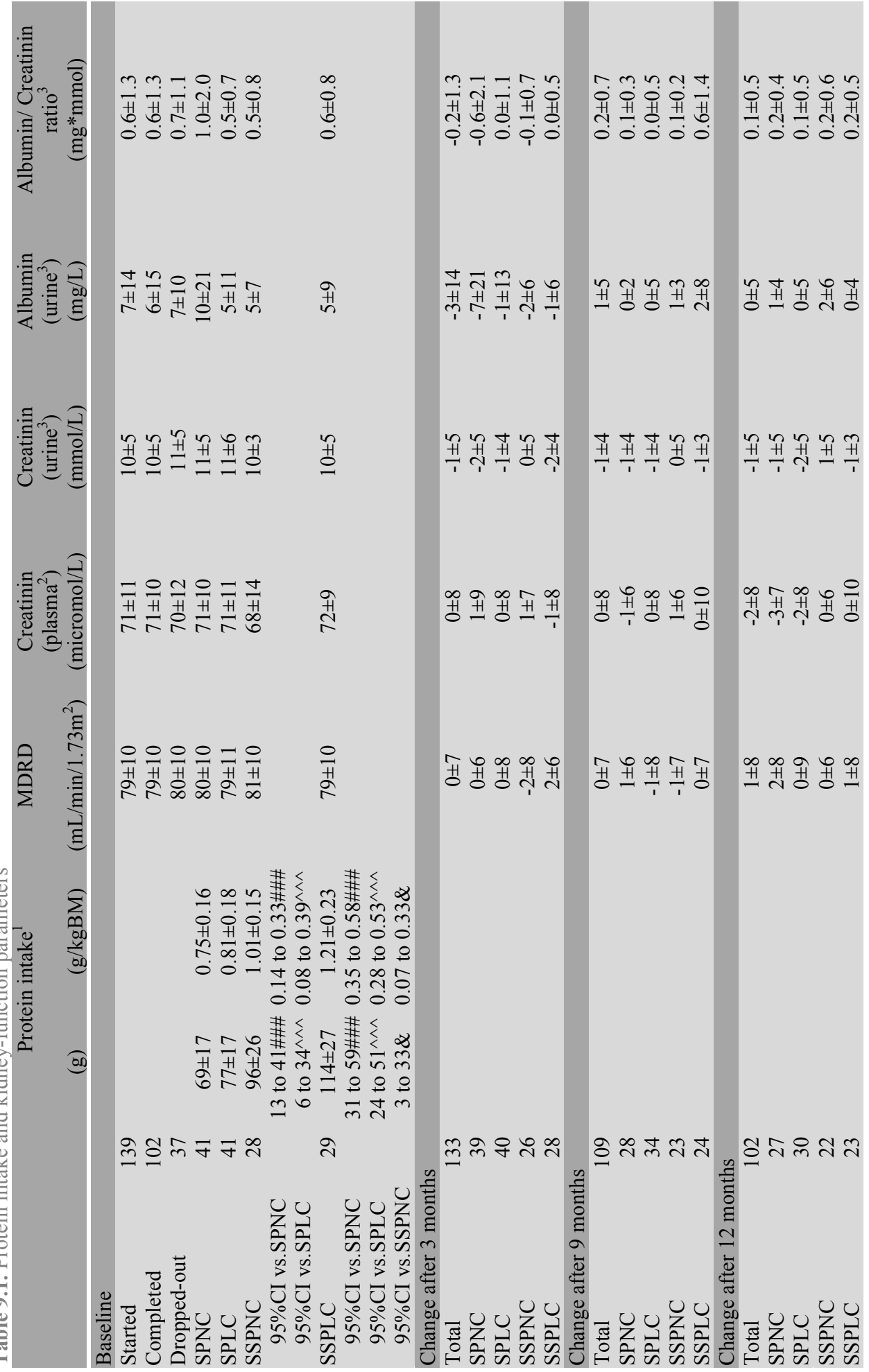


Mean values \pm standard deviations of the sustained-protein normal-carbohydrate (SPNC), the sustained-protein low-carbohydrate (SPLC), the supra-sustained-protein normal-carbohydrate (SSPNC), and the supra-sustained-protein low-carbohydrate (SSPLC) diet groups.

\#\#\# $<<0.001$; treatment between groups with $95 \%$ Confidence Interval, SSPLC or SSPNC vs. SPNC. $\wedge \wedge \wedge p<0.001$; treatment between groups with $95 \%$ Confidence Interval, SSPLC or SSPNC vs. SPLC.

${ }^{\&} \mathrm{p}<0.05$; treatment between groups with $95 \%$ Confidence Interval, SSPLC vs. SSPNC.

${ }^{1}$ Average protein intake during energy restriction based upon nitrogen content of two 24-hour urine samples.

${ }^{2}$ Concentration of plasma after overnight fasting.

${ }^{3}$ Concentration of portion-urine after overnight fasting.

group $(1+10), 6$ in the SSPNC-group $(2+4)$, and 6 in the SSPLC-group $(1+5)$. Participants stopped due to several reasons, such as personal reasons and inability to fulfill the schedule with visits to the clinic.

\section{Dietary intervention}

Prescribed dietary intake was restricted during weight maintenance with $-33 \%$ for 9 months after a weight-loss phase of 3 months with energy intake restriction of $-67 \%$. Prescribed energy intake was calculated for each participant individually based upon the equation of Harris-Benedict for estimation of basal metabolic rate, and multiplied by a Physical Activity Index (PAL) of 1.5 for total energy expenditure. The diets had the following macronutrient composition of energy percent of protein/carbohydrate/fat: SPNC 15/45/40, SPLC 15/25/60, SSPNC 30/45/25, and SSPLC 30/25/45 during the weight maintenance phase. Baseline protein intake was kept constant in grams during the entire 12 months to ensure sufficient protein availability for the preservation of fat free mass.

\section{Counseling}

Participants followed a standardized group-organized program, guided by dietitians and containing participants from all diet groups. The program focused on eating behavior and healthy diet. Diets were supplemented, if necessary, with whey-protein milkshakes (Ollyxa, The Netherlands) to reach the prescribed protein content of the diet. Participants visited the clinic every week in the first month, every 2 weeks in the following 3 months and once a month in the last 8 months, in total 19 sessions over the 12 months. Participants started in groups over one year to exclude seasonal effects.

\section{Measurements}

At the clinic, body weight was measured at all visits. Subjects were weighed in their underwear after an overnight fast, using a calibrated hospital scale to the nearest $0.1 \mathrm{~kg}$ (Tanita TBF-310). Height was measured at screening to the nearest $0.1 \mathrm{~cm}$ (Secastadiometer). Waist circumference was measured each month at the site of smallest circumference between rib cage and iliac crest and hip circumference was measured at the site of largest circumference between waist and thighs. Systolic and diastolic blood pressures were recorded each month using an automatic blood pressure monitor with subjects in sitting position (Microlife BP 3AC1-2).

Body composition was assessed at baseline and after 3,9 and 12 months with the deuterium-dilution technique (11). The dilution of the deuterium isotope $\left({ }^{2} \mathrm{H}_{2} \mathrm{O}\right)$ is a 
measure for total body water. Fat free mass was calculated by dividing total body water by the hydrating factor 0.73 .

To determine physical activity the validated Baecke-questionnaire was used.

To determine whether attitudes towards food intake changed during the experiment, a validated Dutch translation of the Three Factor Eating Questionnaire (TFEQ) was used.

Fasting venous blood samples were taken at baseline and after 3, 9 and 12 months to analyse concentrations of plasma insulin, glucose, creatinin, TAG, HDL, LDL and total cholesterol, and concentrations of albumin and creatinin in urine samples. Furthermore, 24-hour urine nitrogen content was determined. Participants were thoroughly instructed to collect all urine excreted after the first volume voided in the morning until and including the first morning urine voided the following day. Urine samples were collected in containers with $10 \mathrm{~mL} \mathrm{H}_{2} \mathrm{SO}_{4}$ to prevent nitrogen loss through evaporation. Volume and nitrogen concentration were measured, the latter with a nitrogen analyzer (CHN-O-Rapid; Heraeus, Hanau, Germany). Plasma was obtained by centrifugation $\left(1500^{*} \mathrm{~g}\right.$ for $10 \mathrm{~min}$ at $4{ }^{\circ} \mathrm{C}$ ), frozen in liquid nitrogen and stored at $-80^{\circ} \mathrm{C}$ until analysis. Insulin was measured using an immuno-metrical chemoluminescention assay on an Immulite 2000 analyser (Siemens Medical Solutions Diagnostics). Albumin, creatinin, glucose, TAG, HDL and total cholesterol were measured using a standardized enzymatic colorimetric method on the Cobas 6000 analyzer (Roche Diagnostics). LDL cholesterol was calculated according to the Friedewald formula. HOMA-index was calculated by glucose $(\mathrm{mmol} / \mathrm{L}) *$ insulin (mUnits/L)/22.5.

\section{Statistical analysis}

Data are presented as means with standard deviations unless otherwise stated. Differences between groups were tested by ANCOVA with baseline values as covariate. Changes over time between and within groups were tested by factorial repeated-measures ANOVA with Bonferroni post hoc corrections. Differences were regarded as significant if $\mathrm{p}<0.05$. All analyses were performed with the Statistical Package for the Social Sciences (SPSS) version 16.0.2 for Macintosh OS X.

\section{RESULTS}

\section{Protein intake}

Protein intake was kept constant at a sustained level of $0.8 \mathrm{~g} / \mathrm{kgBM}$ or a suprasustained level of 1.0 to $1.2 \mathrm{~g} / \mathrm{kgBM}$. The supra-sustained-protein diets increased daily protein intake during the 3 months of weight loss and 9 months of weight maintenance thereafter to a significant higher level compared to the sustained-protein diets $(\mathrm{p}<0.001$, Table 9.1). Kidney-function parameters did not change over time and were not different between diet-groups.

\section{Body weight}

Body weight was significantly reduced after 12 months in all groups $(\mathrm{p}<0.05$, Table 9.2). After a reduction of $-15 \mathrm{~kg}$ of the most successful diet SSPLC to $-11 \mathrm{~kg}$ of the least successful diet SPNC after 3 months of energy restriction, all groups 
preserved the reduced body weight during the first 6 months of weight maintenance. The last 3 months of weight maintenance thereafter resulted in significant weight regain over time compared to achieved weight loss during energy restriction in the SPNC, SPLC and SSPLC diet (Figure 9.1). The SSPNC-diet was the only diet that did not regain in body weight over the 9 months of weight maintenance after successful weight loss of $-13 \mathrm{~kg}$. Thus, there is a divergence from 6 to 9 months of weight regain between the diets. The SSPNC-diet regained significantly less compared to the SPNC$(1.3 \mathrm{~kg}$ less with $95 \% \mathrm{CI}$ of 0.4 to $2.3 \mathrm{~kg})$ and SPLC- $(1.1 \mathrm{~kg}$ less with $95 \% \mathrm{CI}$ of 0.2 to $2.1 \mathrm{~kg})$ diets $(\mathrm{p}<0.05)$. Overall, the SSP-compared to the SP-diets regained the last 3 months significantly less in body weight $(\mathrm{p}<0.01)$ and resulted in significantly larger decrease in body weight after the 12 months of dietary intervention (delta 12 months baseline SSP vs. SP $-2.3 \mathrm{~kg}$ more with $95 \% \mathrm{CI}$ of -4.4 to $-0.1 \mathrm{~kg}, \mathrm{p}<0.05)$ due to the success of SSPLC during energy restriction and the success of SSPNC during weight maintenance (Figure 9.2).

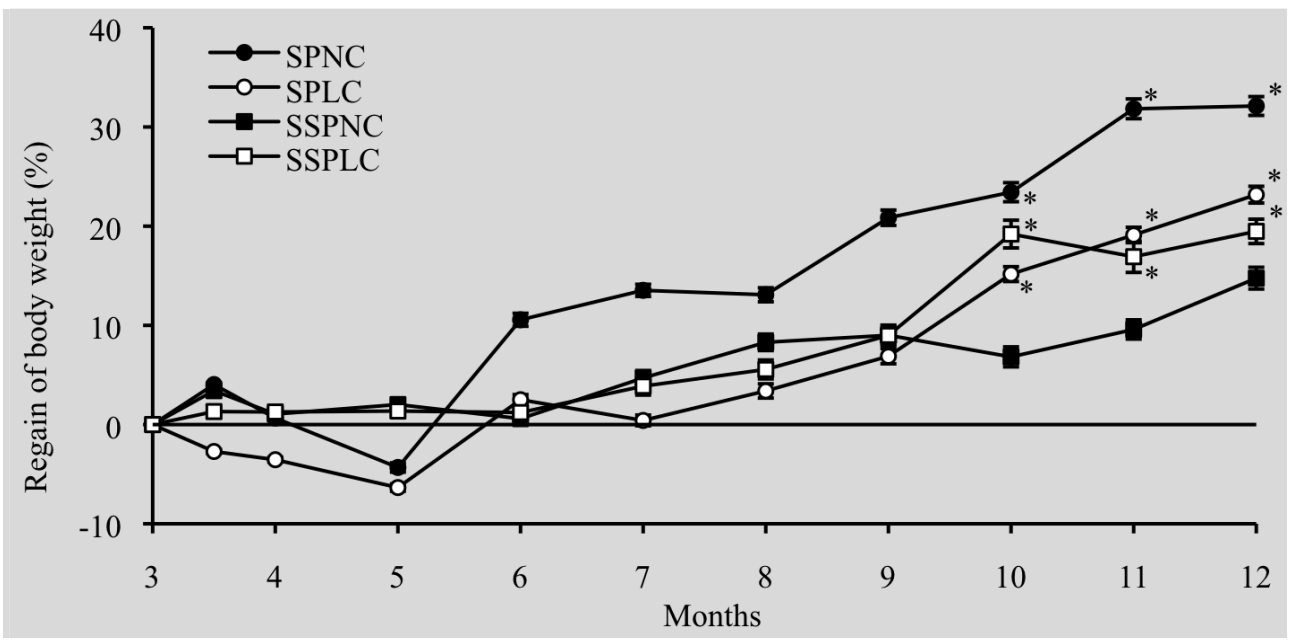

Figure 9.1. Means and SEM of regain in body weight during 9-months after weight loss of the sustained-protein normal-carbohydrate (SPNC), the sustained-protein low-carbohydrate (SPLC), the supra-sustained-protein normal-carbohydrate (SSPNC), and the supra-sustained-protein lowcarbohydrate (SSPLC) diet group.

* $\mathrm{p}<0.05$, over time, regain in body weight vs. weight lost at 3 months of SSPLC, SPLC, and SPNC.

\section{Body composition}

Fat mass, fat percentage, and waist- and hip-circumference decreased in all groups during the 12 months of dietary intervention ( $p<0.05$, Table 9.2). After the successful decrease in fat mass during the 3 months of energy restriction, fat mass did not increase during the first 6 months of weight maintenance thereafter. However, fat mass regained significantly during the last 3 months in the SPNC-, SPLC- and SSPLC-diets $(p<0.05)$. The SSPNC-diet was thus the only diet that did not increase fat mass during the 9 months of weight maintenance. 


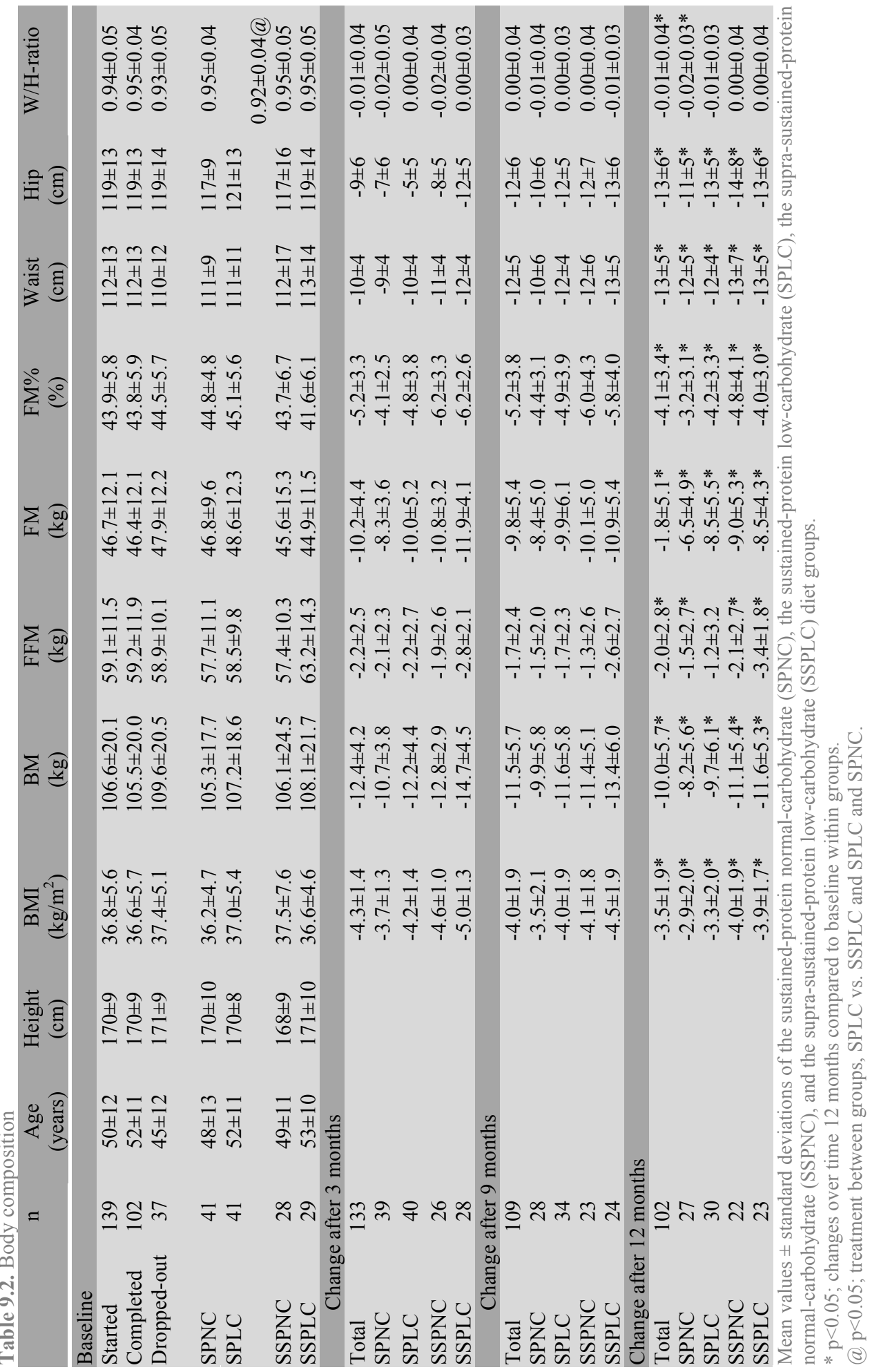




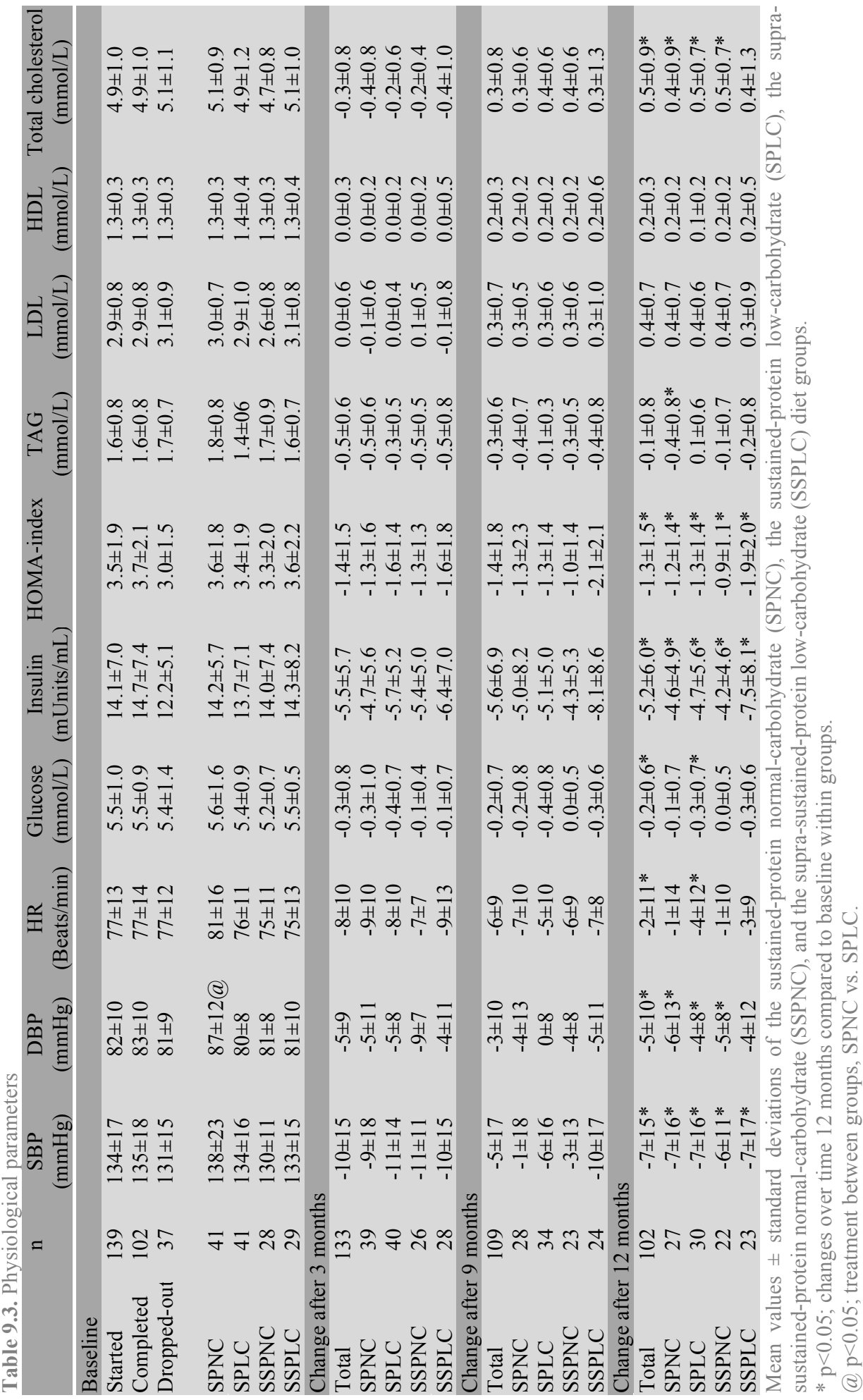




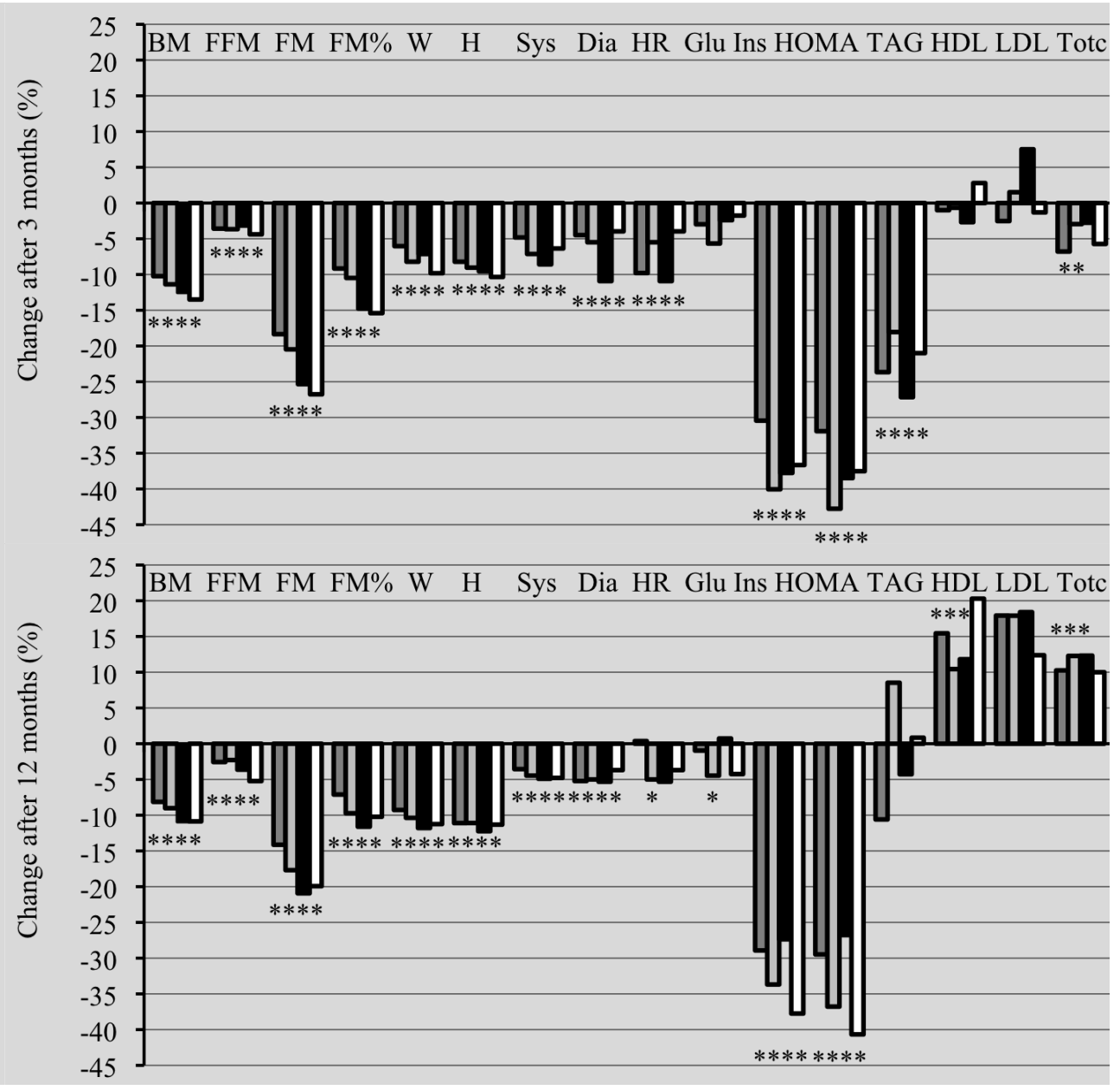

Figure 9.2. Means of percentage decrease in body weight, body composition and metabolic markers after 3 months of weight loss and 9 months of weight maintenance thereafter of the sustained-protein normal-carbohydrate (SPNC) $\square$, the sustained-protein low-carbohydrate (SPLC) $\square$, the suprasustained-protein normal-carbohydrate (SSPNC) $\square$, and the supra-sustained-protein lowcarbohydrate diet group (SSPLC) $\square$

$* \mathrm{p}<0.05$, over time, decrease in body weight, body composition and metabolic markers compared to baseline.

\section{Metabolic profille}

Blood pressure, HOMA-index and fasting plasma concentrations of insulin decreased after 12 months $(\mathrm{p}<0.05$, Table 9.3). HOMA-index (SSPNC $+0.4 \mathrm{mUnits} / \mathrm{L}$ with $95 \% \mathrm{CI}$ of 0.1 to 0.7 and $\mathrm{SPNC}+0.6 \mathrm{mUnits} / \mathrm{L}$ with $95 \% \mathrm{CI}$ of 0.1 to $1.0, \mathrm{p}<0.05$ ) and insulin (SSPNC +1.6 mUnits/L with $95 \% \mathrm{CI}$ of 0.3 to $2.9 \mathrm{mUnits} / \mathrm{L}$ and $\mathrm{SPNC}+$ $1.9 \mathrm{mUnits} / \mathrm{L}$ with $95 \% \mathrm{CI}$ of 0.3 to $3.4 \mathrm{mUnits} / \mathrm{L}, \mathrm{p}<0.05)$ regained partly in both normal carbohydrate diets but not in the low carbohydrate diets during the 9 months of weight maintenance after an initial decrease during 3 months of energy restriction. Total, LDL and HDL cholesterol, and TAG regained in all diets $(\mathrm{p}<0.05$, Figure 9.2). 
Total and HDL cholesterol fasting plasma concentrations increased over the 12 months $(\mathrm{p}<0.05$, Table 9.3). Changes over the 12 months of decrease in systolic $(r=0.267$, $\mathrm{p}<0.01)$ and diastolic blood pressure $(\mathrm{r}=0.205, \mathrm{p}<0.05)$, and heart rate $(\mathrm{r}=0.293$, $\mathrm{p}<0.005)$ were related to the decrease in BMI. Decrease in insulin $(r=0.263$ and $\mathrm{r}=0.344, \mathrm{p}<0.01)$, HOMA-index $(\mathrm{r}=0.271$ and $\mathrm{r}=0.340, \mathrm{p}<0.01)$ and $\mathrm{TAG}(\mathrm{r}=0.207$ and $\mathrm{r}=0.216, \mathrm{p}<0.05)$, and increase in HDL cholesterol $(\mathrm{r}=-0.286$ and $\mathrm{r}=-0.285, \mathrm{p}<0.005)$ were related to the decrease in fat mass and BMI.

Table 9.4. Physical activity and eating behavior

\begin{tabular}{|c|c|c|c|c|c|c|c|c|}
\hline & & Work $^{1}$ & Sport $^{1}$ & Leisure time ${ }^{1}$ & Baecke $^{1}$ & TFEQ F $^{2}$ & TFEQ F $2^{3}$ & TFEQ F $^{4}$ \\
\hline \multicolumn{9}{|l|}{ Baseline } \\
\hline Started & 139 & $2.5 \pm 0.8$ & $2.3 \pm 0.8$ & $2.9 \pm 0.7$ & $7.6 \pm 1.6$ & $7.8 \pm 4.1$ & $6.5 \pm 2.8$ & $4.9 \pm 3.5$ \\
\hline Completed & 102 & $2.5 \pm 0.8$ & $2.4 \pm 0.8$ & $2.9 \pm 0.6$ & $7.7 \pm 1.6$ & $7.9 \pm 4.1$ & $6.3 \pm 2.9$ & $4.7 \pm 3.4$ \\
\hline Dropped-out & 37 & $2.6 \pm 0.8$ & $2.0 \pm 0.8$ & $2.8 \pm 0.8$ & $7.3 \pm 1.7$ & $7.5 \pm 3.9$ & $7.0 \pm 2.7$ & $5.5 \pm 3.7$ \\
\hline SPNC & 41 & $2.6 \pm 0.8$ & $2.3 \pm 0.7$ & $2.8 \pm 0.6$ & $7.6 \pm 1.4$ & $7.0 \pm 3.9$ & $6.2 \pm 2.7$ & $4.3 \pm 3.3$ \\
\hline SPLC & 41 & $2.5 \pm 0.9$ & $2.3 \pm 0.9$ & $2.9 \pm 0.8$ & 1.8 & $8.3 \pm 4.4$ & $6.2 \pm 3.1$ & $4.3 \pm 3.6$ \\
\hline SSPNC & 28 & $2.4 \pm 0.9$ & $2.1 \pm 0.8$ & $3.0 \pm 0$ & $.5 \pm 1.6$ & $7.8 \pm 4.0$ & $5 \pm 2.8$ & $6.1 \pm 3.7$ \\
\hline SSPLC & 29 & $2.5 \pm 0.8$ & $2.3 \pm 1.0$ & & 7.6 & $8.2 \pm 3.9$ & $6.3 \pm 2.7$ & $5.4 \pm 3.1$ \\
\hline \multicolumn{9}{|c|}{ Change after 3 months } \\
\hline Total & 133 & $0.0 \pm 0.8$ & $0.1 \pm 0.6$ & $0.1 \pm$ & $0.2 \pm 1.2$ & $3.8 \pm 3.7$ & $-1.7 \pm 2.5$ & $-1.7 \pm 2.9$ \\
\hline SPNC & 39 & $0.0 \pm 0.9$ & $0.1 \pm 0.7$ & $0.1 \pm 0.4$ & $0.2 \pm 1.3$ & $4.4 \pm 3.9$ & $-1.3 \pm 2.4$ & $-1.4 \pm 2.6$ \\
\hline SPLC & 40 & $0.1 \pm 0.7$ & $0.1 \pm 0.6$ & $0.0 \pm 0.6$ & $0.1 \pm 1.2$ & $2.2 \pm 2.8$ & $-1.5 \pm 2.6$ & $-1.1 \pm 3.5$ \\
\hline SSPNC & 26 & $0.2 \pm 0.6$ & $0.3 \pm 0.7$ & $0.2 \pm 0.5$ & $0.2 \pm 1.2$ & $5.0 \pm 4.4$ & $-2.8 \pm 2.5$ & $-3.0 \pm 2.9$ \\
\hline SSPLC & 28 & $-0.1 \pm 0.9$ & $0.0 \pm 0.5$ & $0.0 \pm 0.3$ & $-0.1 \pm 1.2$ & $4.4 \pm 3.4$ & $-1.5 \pm 2.4$ & $-1.9 \pm 2.3$ \\
\hline \multicolumn{9}{|c|}{ Change after 9 months } \\
\hline Total & 109 & $0.2 \pm 0.7$ & $0.1 \pm 0.7$ & $0.1 \pm 0.4$ & $0.4 \pm 1.1$ & $4.0 \pm 3.6$ & $-1.1 \pm 2.5$ & $-1.4 \pm 2.5$ \\
\hline SPNC & 28 & $0.0 \pm 0.9$ & $0.1 \pm 0.8$ & $0.1 \pm 0.5$ & $0.2 \pm 1.4$ & $4.0 \pm 3.3$ & $-0.9 \pm 2.4$ & $-0.6 \pm 2.2$ \\
\hline SPLC & 34 & $0.2 \pm 0.6$ & $0.1 \pm 0.5$ & $0.1 \pm 0.3$ & $0.3 \pm 0.7$ & $2.7 \pm 2.8$ & $-0.4 \pm 2.7$ & $-0.9 \pm 2.4$ \\
\hline SSPNC & 23 & $0.3 \pm 0.7$ & $0.3 \pm 0.8$ & $0.1 \pm 0.5$ & $0.8 \pm 1.4$ & $4.4 \pm 4.0$ & $-1.6 \pm 2.5$ & $-1.8 \pm 2.5$ \\
\hline SSPLC & 24 & $0.1 \pm 0.4$ & $0.1 \pm 0.6$ & $0.1 \pm 0.4$ & $0.4 \pm 0.5$ & $5.4 \pm 4.0$ & $-1.6 \pm 2.0$ & $-2.8 \pm 2.3$ \\
\hline \multicolumn{9}{|c|}{ Change after 12 months } \\
\hline Total & 102 & $0.0 \pm 0.8$ & $0.0 \pm 0.7$ & $0.2 \pm 0.5$ & $0.2 \pm 1.2$ & $4.6 \pm 3.8^{*}$ & $-1.4 \pm 2.2^{*}$ & $-1.6 \pm 2.5^{*}$ \\
\hline SPNC & 27 & $-0.2 \pm 0.8$ & $0.1 \pm 0.7$ & $0.3 \pm 0.5$ & $0.1 \pm 1.2$ & $4.6 \pm 3.2 *$ & $-1.1 \pm 2.2^{*}$ & $-1.2 \pm 1.7$ \\
\hline SPLC & 30 & $0.1 \pm 0.7$ & $-0.1 \pm 0.7$ & $0.2 \pm 0.5$ & $0.1 \pm 1.3$ & $3.7 \pm 3.3^{*}$ & $-0.9 \pm 2.4^{*}$ & $-1.2 \pm 2.8^{*}$ \\
\hline SSPNC & 22 & $0.2 \pm 0.8$ & $0.1 \pm 0.7$ & $0.2 \pm 0.5$ & $0.5 \pm 1.4$ & $4.5 \pm 4.6^{*}$ & $-1.8 \pm 2.1^{*}$ & $-2.1 \pm 2.5^{*}$ \\
\hline & 23 & & & $01+0$ & & $59+43 *$ & $-19+19 *$ & \\
\hline
\end{tabular}

Mean values \pm standard deviations of the sustained-protein normal-carbohydrate (SPNC), the sustained-protein low-carbohydrate (SPLC), the supra-sustained-protein normal-carbohydrate (SSPNC), and the supra-sustained-protein low-carbohydrate (SSPLC) diet groups.

$* \mathrm{p}<0.05$; changes over time 12 months compared to baseline within groups.

${ }^{1}$ The Baecke total activity index and its activity sub-scores of sport, leisure time and work.

${ }^{2}$ A measure of cognitive restraint of the three-factor eating questionnaire (TFEQ); minimum score 0 , maximum score 21; cut-off point fort the Dutch population 9. Values greater than 9 indicate cognitive restraint eating.

${ }^{3}$ A measure of disinhibition or emotional eating of the TFEQ; minimum score 0 , maximum score 14.

${ }^{4}$ A general feeling of hunger of the TFEQ; minimum score 0 , maximum score 14 .

\section{Physical activity and eating behavior}

Physical activity did not change after the 12 months and groups did not differ in changes in physical activity (Table 9.4). TFEQ-scores of dietary restraint (F1) increased, and scores of disinhibition (F2) decreased $(\mathrm{p}<0.05)$. Subjective feeling of 
hunger (F3) decreased in both SSP-diets $(\mathrm{p}<0.05)$, but not in both SP-diets. Furthermore, changes over the 12 months of restraint score and hunger score were inter-related $(\mathrm{r}=-0.287, \mathrm{p}<0.005)$.

\section{DISCUSSION}

All diets decreased body weight after one year of dietary intervention; SSPLC $-11 \%$, SSPNC $-11 \%$, SPLC -9\%, and SPNC -8\%. The SSPNC-diet was most successful in limiting weight regain. It was the only diet that did not regain body weight during 9 months of weight maintenance after initial body-weight loss during 3 months of energy restriction. The supra-sustained-protein intake of $1.2 \mathrm{~g} / \mathrm{kgBM}$ vs. the sustained-protein intake of $0.8 \mathrm{~g} / \mathrm{kgBM}$ was more effective in reducing body weight. Protein intake was quantified by 24-hour urine nitrogen content, and confirmed thereby the presence and magnitude of contrast in protein intake between the SP- and SSP-diets over the 12 months of dietary intervention. These findings are in line with the principles of the protein leverage hypothesis (2); a diet containing a higher percentage of protein, eaten until the intake target of protein is reached, will result in a lower intake of carbohydrate and fat, and thereby create an energy deficit leading to weight loss. Furthermore, maintenance of reduced body weight during weight maintenance is supported by proteins high-satiating capacity $(4,5,12-14)$ and high-thermogenic respons after a meal (14-19) compared to carbohydrates and fat. Both SSP-diets even decreased hunger during weight maintenance, thereby limiting energy intake. Next to decrease in subjective feeling of hunger compliance to the diet, supported by an increase in dietary restraint, a measure of control of food intake by thought and will-power, and decrease in disinhibition of control, an incidental inability to resist eating cues, reinforces the effects of proteins in the diet.

The low carbohydrate content of the SSPLC-diet creates as a consequence of increased hepatic gluconeogenesis a situation where protein requirements are increased, leading to a situation where more energy will be eaten until this higher intake target of protein is reached (2). Furthermore, the relatively high fat intake during this diet may stimulate fat accumulation in the body and thereby facilitate weight regain, as reducing fat content in an ad libitum diet produces some weight loss (20). Moreover, after a period of energy restriction resulting in body-weight loss, the loss of fat free mass will increase the requirement of protein. Thus, weight maintenance after weight loss benefits from a diet with a higher ratio of protein to carbohydrate and fat. Furthermore, sparing of fat free mass is important, as it is the main determinant of resting (21) and 24-hour energy expenditure (22), and thereby facilitates weight maintenance after weight loss. Thus, the effects of proteins on energy intake and energy expenditure help to optimize compliance to energy-restricted diets to result in optimal body-weight loss (3-5, 23-25) and weight maintenance thereafter.

Targeting obesity is a way to decrease metabolic risk factors of several diseases related to the excess of body weight and fat mass. The metabolic profile remarkably improved as a result of the reduction of body weight and fat mass. Blood pressure, insulin and HOMA-index remained decreased after weight maintenance. The low carbohydrate intake reinforced the long-term decrease in HOMA-index. HDL and total cholesterol increased over the year, while the TAG and LDL also regained during weight maintenance. Previously protein rich diets improved blood pressure (26-28), 
glycaemic control (29) and fasting plasma lipid profile concentrations, i.e. they resulted into a greater increase in HDL cholesterol (30-32), a greater reduction of LDL cholesterol $(16,31,32)$ and a greater reduction of TAG $(24,31,32)$ during weight maintenance. Furthermore, none of the diets changed kidney function parameters. The WHO-report no. 935 'Protein and amino acid requirements in human nutrition' states that 'the value accepted for the safe level of protein intake is $0.83 \mathrm{~g} / \mathrm{kg}$ per day'. Furthermore, it states that 'no safe upper limit has been identified, and it is unlikely that intakes of twice the safe level are associated with any risk'.

In conclusion, elevated-protein plus normal-carbohydrate diet is most effective in maintaining reduced body weight, followed by the limiting effect on weight regain of protein diets with $1.0-1.2 \mathrm{~g} / \mathrm{kg}$ body weight irrespective of the carbohydrate content. Protein intakes of 0.8 to $1.2 \mathrm{~g} / \mathrm{kg}$ body weight improve the metabolic profile, while low vs. normal carbohydrate intake is more effective in improving HOMA-index.

\section{ACKNOWLEDGEMENTS}

We gratefully acknowledge collaboration with Previtas, Annemieke Izeboud, WillemJan Toubes and Bruce Wolffenbuttel. The study was supported by Top Institute Food and Nutrition (TIFN, Wageningen, The Netherlands). 


\section{REFERENCES}

1. Amigo I, Fernandez C. Effects of diets and their role in weight control. Psychol Health Med 2007;12:321-7.

2. Simpson SJ, Raubenheimer D. Obesity: the protein leverage hypothesis. Obes Rev 2005;6:13342.

3. Krieger JW, Sitren HS, Daniels MJ, Langkamp-Henken B. Effects of variation in protein and carbohydrate intake on body mass and composition during energy restriction: a meta-regression 1. Am J Clin Nutr 2006;83:260-74.

4. Lejeune MP, Kovacs EM, Westerterp-Plantenga MS. Additional protein intake limits weight regain after weight loss in humans. Br J Nutr 2005;93:281-9.

5. Weigle DS, Breen PA, Matthys CC, et al. A high-protein diet induces sustained reductions in appetite, ad libitum caloric intake, and body weight despite compensatory changes in diurnal plasma leptin and ghrelin concentrations. Am J Clin Nutr 2005;82:41-8.

6. Gardner CD, Kiazand A, Alhassan S, et al. Comparison of the Atkins, Zone, Ornish, and LEARN diets for change in weight and related risk factors among overweight premenopausal women: the A TO Z Weight Loss Study: a randomized trial. Jama 2007;297:969-77.

7. Boden G, Sargrad K, Homko C, Mozzoli M, Stein TP. Effect of a low-carbohydrate diet on appetite, blood glucose levels, and insulin resistance in obese patients with type 2 diabetes. Ann Intern Med 2005;142:403-11.

8. Dansinger ML, Gleason JA, Griffith JL, Selker HP, Schaefer EJ. Comparison of the Atkins, Ornish, Weight Watchers, and Zone diets for weight loss and heart disease risk reduction: a randomized trial. Jama 2005;293:43-53.

9. Foster GD, Wyatt HR, Hill JO, et al. A randomized trial of a low-carbohydrate diet for obesity. N Engl J Med 2003;348:2082-90.

10. Samaha FF, Iqbal N, Seshadri P, et al. A low-carbohydrate as compared with a low-fat diet in severe obesity. N Engl J Med 2003;348:2074-81.

11. Westerterp KR, Wouters L, van Marken Lichtenbelt WD. The Maastricht protocol for the measurement of body composition and energy expenditure with labeled water. Obes Res 1995;3 Suppl 1:49-57.

12. Astrup A. The satiating power of protein--a key to obesity prevention? Am J Clin Nutr 2005;82:1-2.

13. Westman EC, Yancy WS, Edman JS, Tomlin KF, Perkins CE. Effect of 6-month adherence to a very low carbohydrate diet program. Am J Med 2002;113:30-6.

14. Westerterp-Plantenga MS, Rolland V, Wilson SA, Westerterp KR. Satiety related to $24 \mathrm{~h}$ diet induced thermogenesis during high protein/carbohydrate vs high fat diets measured in a respiration chamber. Eur J Clin Nutr 1999;53:495-502.

15. Raben A, Agerholm-Larsen L, Flint A, Holst JJ, Astrup A. Meals with similar energy densities but rich in protein, fat, carbohydrate, or alcohol have different effects on energy expenditure and substrate metabolism but not on appetite and energy intake. Am J Clin Nutr 2003;77:91-100.

16. Parker B, Noakes M, Luscombe N, Clifton P. Effect of a high-protein, high-monounsaturated fat weight loss diet on glycemic control and lipid levels in type 2 diabetes. Diabetes Care 2002;25:425-30.

17. Westerterp KR, Wilson SA, Rolland V. Diet induced thermogenesis measured over $24 \mathrm{~h}$ in a respiration chamber: effect of diet composition. Int J Obes Relat Metab Disord 1999;23:287-92.

18. Tappy L. Thermic effect of food and sympathetic nervous system activity in humans. Reprod Nutr Dev 1996;36:391-7.

19. Nair KS, Halliday D, Garrow JS. Thermic response to isoenergetic protein, carbohydrate or fat meals in lean and obese subjects. Clin Sci (Lond) 1983;65:307-12.

20. Astrup A, Grunwald GK, Melanson EL, Saris WH, Hill JO. The role of low-fat diets in body weight control: a meta-analysis of ad libitum dietary intervention studies. Int J Obes Relat Metab Disord 2000;24:1545-52.

21. Halliday D, Hesp R, Stalley SF, Warwick P, Altman DG, Garrow JS. Resting metabolic rate, weight, surface area and body composition in obese women. Int J Obes 1979;3:1-6. 
22. Ravussin E, Lillioja S, Anderson TE, Christin L, Bogardus C. Determinants of 24-hour energy expenditure in man. Methods and results using a respiratory chamber. J Clin Invest 1986;78:1568-78.

23. Due A, Toubro S, Skov AR, Astrup A. Effect of normal-fat diets, either medium or high in protein, on body weight in overweight subjects: a randomised 1-year trial. Int J Obes Relat Metab Disord 2004;28:1283-90.

24. Layman DK, Boileau RA, Erickson DJ, et al. A reduced ratio of dietary carbohydrate to protein improves body composition and blood lipid profiles during weight loss in adult women. J Nutr 2003;133:411-7.

25. Skov AR, Toubro S, Ronn B, Holm L, Astrup A. Randomized trial on protein vs carbohydrate in ad libitum fat reduced diet for the treatment of obesity. Int J Obes Relat Metab Disord 1999;23:528-36.

26. Appel LJ, Sacks FM, Carey VJ, et al. Effects of protein, monounsaturated fat, and carbohydrate intake on blood pressure and serum lipids: results of the OmniHeart randomized trial. Jama 2005;294:2455-64.

27. Hu FB. Protein, body weight, and cardiovascular health. Am J Clin Nutr 2005;82:242S-247S.

28. Appel LJ, Moore TJ, Obarzanek E, et al. A clinical trial of the effects of dietary patterns on blood pressure. DASH Collaborative Research Group. N Engl J Med 1997;336:1117-24.

29. Promintzer M, Krebs M. Effects of dietary protein on glucose homeostasis. Curr Opin Clin Nutr Metab Care 2006;9:463-8.

30. Baba NH, Sawaya S, Torbay N, Habbal Z, Azar S, Hashim SA. High protein vs high carbohydrate hypoenergetic diet for the treatment of obese hyperinsulinemic subjects. Int J Obes Relat Metab Disord 1999;23:1202-6.

31. Wolfe BM, Piche LA. Replacement of carbohydrate by protein in a conventional-fat diet reduces cholesterol and triglyceride concentrations in healthy normolipidemic subjects. Clin Invest Med 1999;22:140-8.

32. Wolfe BM, Giovannetti PM. Short-term effects of substituting protein for carbohydrate in the diets of moderately hypercholesterolemic human subjects. Metabolism 1991;40:338-43. 



\section{RELATIONSHIP BETWEEN PERILIPIN}

\section{GENE POLYMORPHISMS AND}

\section{BODY WEIGHT AND BODY COMPOSITION}

\section{DURING WEIGHT LOSS AND WEIGHT MAINTENANCE}

Stijn Soenen, EdWin CM Mariman, NeEltJe Vogels,

Freek G Bouwman, MARCEL den Hoed, Louise Brown AND MARgriet S WeSterterp-Plantenga

PHYSIOL BEHAV 2009;96:723-728 


\section{ABSTRACT}

\section{Background}

Genetic variation in the perilipin (PLIN) gene may play a role in the etiology and treatment of obesity.

\section{Objective}

To examine different polymorphisms in the PLIN gene in relation to body-weight regulation.

\section{Design}

118 subjects followed a 6-week very low caloric diet (VLCD), followed by 1-year weight maintenance. Body-weight, body composition, leptin concentration, and polymorphisms of the PLIN gene: PLIN 1 rs2289487, PLIN 4 rs894160, PLIN 6 rs1052700, PLIN 5 rs2304795 and PLIN 7 rs 2304796 were determined.

\section{Results}

Body-weight loss during VLCD was $7.0 \pm 3.1 \mathrm{~kg}(\mathrm{p}<0.05)$, and body-weight regain was $3.7 \pm 1.4 \mathrm{~kg} \quad(\mathrm{p}<0.05)$, including changes in BMI, waist circumference, body composition and leptin concentrations $(p<0.05)$. Linkage disequilibria were observed between PLIN 1 and PLIN 4: D'>0.9, $\mathrm{r}^{2}=0.72$; PLIN 5 and PLIN 7: D'>0.9, $\mathrm{r}^{2}=0.85$. In men, body weight, BMI, waist circumference, body fat, leptin concentrations were significantly lower for the haplotype of PLIN1 (C-alleles) and PLIN 4 (A-alleles). In women body-weight loss and loss of fat mass was larger for the haplotype of PLIN 1 (C-alleles) and PLIN 4 (A-alleles). For PLIN 6 genotypes body weight and body fat was lower for homozygotes of the minor allele (T/T) in the men; in the women leptin concentrations were lower. The haplotype of PLIN 5 and PLIN 7 consisting of G/G and $\mathrm{A} / \mathrm{G}$ of PLIN5 and A/A of PLIN 7 showed a reduction of fat mass $5.9 \pm 0.6 \mathrm{~kg}$ vs. $3.1 \pm 0.4 \mathrm{~kg}$, fat: fat percentage $5.5 \pm 0.6 \%$ vs. $2.2 \pm 0.2 \%$, and leptin $20.5 \pm 10.8 \mathrm{ng} / \mathrm{mL}$ vs. $12.9 \pm 6.7 \mathrm{ng} / \mathrm{mL}$ over time in the women $(\mathrm{p}<0.05)$.

\section{Conclusion}

The PLIN 1-4, 6, and 5-7 loci appear as a genetic influencer of obesity risk in humans. The haplotype of the minor alleles PLIN 1-4, PLIN 6, and PLIN 5-7 was related to body-weight regulation at a lower level of body weight in men as well in women.

\section{Keywords}

obesity, body composition, gender, perilipin polymorphisms 


\section{INTRODUCTION}

Overweight and obesity are emerging as major health problems, and it is only recently that understanding on how genetic variation impacts weight management has started to emerge. For instance, an association between perilipin (PLIN) gene variants and weight gain has been suggested. The perilipins are part of an ancient family of proteins that interact with the surfaces of intracellular neutral lipid droplets. Collectively, these have been called the PAT family, after the founding member Perilipin and two other related mammalian proteins ADRP and TIP-47 (1). Perilipin exists in different isoforms. These isoforms are the products of differentially spliced transcripts from a single gene, PLIN (2). The predominant form expressed in adipocytes (3), is involved in regulating fat storage, primarily by modulating hormone sensitive lipase (HSL) activity. HSL mediates the hydrolysis of triacylglycerol, a major form of stored energy in the body.

Studies in rodents have shown that loss of the PLIN gene results in a lean phenotype and protection against high-fat diet-induced obesity $(4,5)$. The plin -/phenotype is marked by a reduction of stored adipose mass of approximately $60-70 \%$, normal body weight despite increased food intake, increased muscle mass, increased metabolic rate and oxygen consumption and near-maximal lipolysis (in adipocytes) under basal conditions. The increase in basal lipolysis is a consequence of constitutively activated HSL (6). A conformational change of perilipin as a consequence of phosphorylation facilitates proper HSL translocation and allows lipolysis to occur. Concomitant with phosphorylation of this perilipin isoform, PKA also phosphorylates and activates HSL (6). Constitutive activation of lipolysis would be expected to result in an increase in plasma levels of free fatty acids. However, surprisingly this was not found to be the case in plin -/- animals (5). The increase in lipolytic activity may be accompanied by a compensatory increase in free fatty acid utilisation. In line with this idea absence of perilipin appeared to result in increased beta-oxidation in muscle, adipose and liver and an altered pattern of gene (e.g. ACC $1 / 2$, CPT-1) expression that would support a 'fat burning' phenotype (7).

In human studies, for example in a Spanish population, a gender specific association with a genetic variation at position 6209 (PLIN 1 T $>$ C) and 11482 (PLIN 4 $\mathrm{G}>\mathrm{A}$ ) of the PLIN gene in women, but not in men was found (8). The minor alleles of PLIN 1 and PLIN 4 were both associated with low BMI and body weight and both conferred a reduced risk of obesity (OR 0.57 and 0.52 , respectively) (8). Moreover, PLIN 4 allele-specific differences in lipolysis and perlipin protein concentrations in adipose tissue have been observed in Caucasian women, the minor allele being associated with reduced perilipin levels and increased lipolytic activity (9). With respect to postprandial triacylglycerol metabolism in white populations, PerezMartinez et al. observed modifications by the presence of genetic variation at the perilipin locus (10). They conclude that the presence of the minor $\mathrm{C}$ and $\mathrm{A}$ alleles at PLIN 1 and PLIN 4, respectively, are associated with a lower postprandial response that may result in lower atherogenic risk for these persons (10). In addition, Jang et al., showed that genetic variation at the perilipin locus is associated with changes in serum free fatty acids and abdominal fat following mild weight loss (11). With respect to risk of diabetes mellitus type 2 in US-women, Qi et al. report that central obesity may modify the associations between PLIN variations and diabetes risk in women (12). Associations between body weight and genetic variations at positions 13041 (PLIN 5 
$\mathrm{A}>\mathrm{G}$ ) and 14995 (PLIN $6 \mathrm{~A}>\mathrm{T}$ ) have been reported as well, with the minor alleles of PLIN 5 and PLIN 6 both being positively associated with BMI, \% body-fat and waist circumference (10). Furthermore, analysis of inferred haplotypes for PLIN 5/6 revealed an increased risk of obesity for the A/T (OR 1.76) and G/T (OR 1.73) haplotypes (13). Again, these associations were only observed in women.

On the other hand, a French study (14), investigating whether perilipin gene polymorphisms were associated with obesity, diabetes mellitus type 2 and related variables in a cross-sectional sample of 1120 French men and women, observed that the rs4578621 and rs894160 (PLIN 4) polymorphisms of the perilipin gene are not major genetic determinants of obesity and diabetes mellitus type 2 related phenotypes (14).

Taken together, these data implicate the PLIN locus as a possible genetic influencer of obesity risk in humans, women seeming to be more sensitive to the genetic effect of PLIN than men. In addition, genetic variation for PLIN may influence body-weight management. In obese patients genotyped for four polymorphisms at the PLIN locus (PLIN 1/4/5/6) PLIN 4 was found to be statistically $(p<0.05)$ associated with weight and BMI, with A allele carriers having significantly lower body weight and BMI than GG homozygotes. After diet intervention, a statistically significant $(p=0.015)$ gene interaction was observed, but only between PLIN 4 and body-weight decrease in response to diet (15).

From the observations reported, it seems likely that the differential response to a weight-loss weight-maintenance intervention may be supported by a differential effect on body composition, and the role of the PLIN genotype therein. This possible effect was tested in the following study.

\section{METHODS}

\section{Subjects}

Subjects were recruited by advertisements in local newspapers. 133 healthy subjects complied with the selection criteria: BMI $>25 \mathrm{~kg} / \mathrm{m}^{2}$ and age between 20 and 65 years. Participation in another scientific study up to 30 days prior to this study was an exclusion criterion. Age was on average $48.1 \pm 9.5$ years, and BMI was $31.1 \pm 3.7 \mathrm{~kg} / \mathrm{m}^{2}$. Subjects started with a Very Low Calorie Diet (VLCD) for six weeks. Measurements were executed before and after weight loss, and at three months and one year after the end of the weight loss period. At three months weight maintenance 15 subjects dropped-out for several reasons (e.g. moving house). The dropouts did not significantly change the baseline characteristics of the subjects. Data have been analyzed for the 118 subjects (age $49.0 \pm 9.8$ years, BMI $31.0 \pm 3.8 \mathrm{~kg} / \mathrm{m}^{2}$ ) who completed the entire study. Subjects gave their written informed consent to participate in the study, which was approved by the Medical Ethical Committee of Maastricht University (16).

\section{Study design}

The study consisted of a dietary weight-loss intervention under free-living circumstances for six weeks and a weight maintenance period of 1 year. The VLCD (Modifast, Novartis Nutrition, Brussels, Belgium) consisted of $2.1 \mathrm{MJ} / \mathrm{d}(500 \mathrm{kcal} / \mathrm{d})$ given in three sachets per day. It provided $50 \mathrm{~g}$ carbohydrates, $52 \mathrm{~g}$ protein, $7 \mathrm{~g}$ fat and 
a vitamins- and minerals-content which meets the Dutch recommended daily allowance. The VLCD was dissolved in water to make a soup, milkshake or dessert. In addition to the VLCD, subjects were allowed to consume two pieces of fruit and an unrestricted amount of vegetables every day, without sauces or vinaigrettes.

\section{Measurements}

Measurements of body-weight, body composition, leptin concentration, dietary restraint, and physical activity took place at baseline before the VLCD (t0), immediately after the VLCD (t1), 3 months after baseline (t2), and one year after baseline ( $\mathrm{t} 3)$. At baseline one blood sample was taken and stored for DNA analysis (16, 17).

\section{Anthropometry}

Height was measured using a wall-mounted stadiometer (Seca, model 220, Hamburg, Germany) and body weight was measured using a digital balance accurate to $0.1 \mathrm{~kg}$ (Sauter D7470, Ebingen, Germany). Measurements were executed in underwear, after an overnight fast and after voiding the bladder. BMI was calculated by body weight divided by height squared $\left(\mathrm{kg} / \mathrm{m}^{2}\right)$. The waist circumference was measured at the site of the smallest circumference between the rib cage and the iliac crest, with the subjects in standing position (16).

\section{Body composition}

Body composition was measured using the deuterium-dilution technique. Deuterium dilution was used to measure total body water (TBW). Subjects were asked to collect a urine sample in the evening just before drinking the deuterium-enriched water solution. After ingestion of this solution, no further consumption was allowed. Ten hours after drinking the deuterium dilution, another urine sample was collected. The dilution of the deuterium isotope $\left({ }^{2} \mathrm{H}_{2} \mathrm{O}\right)$ is a measure of the total body water of the subject. Deuterium was measured in the urine samples with an isotope ratio mass spectrometer (VG-Isogas Aqua Sira, VG Isogas, Middlewich, Cheshire, England). Total body water was obtained by dividing the measured deuterium-dilution space by 1.04 . Fat free mass was calculated by dividing total body water by the hydration factor $0.73(16,18-20)$.

\section{Leptin}

Blood samples were taken following a 12-hour overnight fast. Serum leptin concentrations were measured with a double-antibody, sandwich-type enzyme-linked immunosorbent assay that used a monoclonal antibody specific for human leptin. The lower limit of detection is $0.5 \mu \mathrm{g} / \mathrm{L}$ and the upper limit is $50 \mu \mathrm{g} / \mathrm{L}$. The intra- and interassay CVs were $9 \%$ and $12 \%$, respectively. The leptin concentrations of normalweight subjects range from 2 to $12 \mu \mathrm{g} / \mathrm{L}$ (16).

\section{DNA isolation and PLIN Genotyping}

The genomic DNA's of 118 subjects were isolated from peripheral blood leukocytes using the QIAamp blood kit from Qiagen. Genotyping of rs2289487 T $>C$ (intron 2) named PLIN 1, rs894160 G>A (intron 6) named PLIN 4, and rs $1052700 \mathrm{~A}>\mathrm{T}$ (exon 9) named PLIN 6, was performed by using commercially available TaqMan SNP 
Genotyping assays from Applied Biosystems. The procedure was performed according to the manufacturer's protocol and analyses were performed on an Applied Biosystems 7900 HT Fast Real-Time PCR System. Allelic calls were determined semiautomatically using the allelic discrimination software of Applied Biosystems.

The genotypes of rs2304795 A>G (exon 8) named PLIN 5 and rs2304796 A>G (exon 8) named PLIN 7 were determined by DNA sequencing. A 184-bp fragment that contained both SNP's was generated from genomic DNA by PCR with the use of forward primer 5'-CTCACCGGCACGTAATGCAC-3' and reverse primer 5'-CCCTCCAGACCACCATCTCG-3'. Sequencing was carried out on an ABI Prism 3100 genetic analyzer from Applied Biosystems using the BigDye Terminator v3.1 Cycle sequence kit.

Table 10.1. Subject characteristics

\begin{tabular}{|c|c|c|c|c|}
\hline & Baseline & $\begin{array}{l}\text { Change after } \\
1.5 \text { months }\end{array}$ & $\begin{array}{l}\text { Change after } \\
4.5 \text { months }\end{array}$ & $\begin{array}{l}\text { Change after } \\
13.5 \text { months }\end{array}$ \\
\hline BMI $\left(\mathrm{kg} / \mathrm{m}^{2}\right)$ & $31.0 \pm 3.8$ & $28.6 \pm 3.6^{*}$ & $28.7 \pm 3.7 *$ & $29.8 \pm 3.8^{*} \#$ \\
\hline BM (kg) & $90.3 \pm 15.4$ & $83.0 \pm 13.8^{*}$ & $83.7 \pm 14.2 *$ & $86.7 \pm 14.9 * \#$ \\
\hline FFM (kg) & $57.1 \pm 12.7$ & $54.6 \pm 11.1^{*}$ & $56.5 \pm 11.9 \#$ & $56.2 \pm 12.0 \#$ \\
\hline FM (kg) & $33.1 \pm 9.0$ & $28.4 \pm 7.3 *$ & $\pm 7.5 * \#$ & 29.8 \\
\hline FM (\%) & $36.8 \pm 7.4$ & $34.3 \pm 6.8^{*}$ & $31.8 \pm 7.1 * \#$ & $34.9 \pm 7.3 *$ \\
\hline Waist (cm) & $102 \pm 12$ & $94 \pm 11 *$ & $95 \pm 11 *$ & $96 \pm 12 * \#$ \\
\hline Baecke $^{1}$ & $8.2 \pm 1.2$ & $8.4 \pm 1.3^{*}$ & $8.4 \pm 1.2 *$ & $8.3 \pm 1.3$ \\
\hline TFEQ F $1^{2}$ & $8.4 \pm 4.5$ & $10.6 \pm 4.7 *$ & $11.5 \pm 4.4^{*}$ & $10.7 \pm 4.5^{*}$ \\
\hline TFEQ F2 ${ }^{3}$ & $5.5 \pm 2.7$ & $5.1 \pm 2.6^{*}$ & $4.9 \pm 2.6^{*}$ & $5.1 \pm 2.7$ \\
\hline TFEQ F $3^{4}$ & $5.5 \pm 3.8$ & $4.0 \pm 3.1 *$ & $3.3 \pm 3.0 *$ & $3.7 \pm 3.1 *$ \\
\hline Leptin (ng/mL) & $26.8 \pm 16.9$ & $9.0 \pm 5.7^{*}$ & $14.7 \pm 8.6^{*} \#$ & $16.7 \pm 8.6^{* \#}$ \\
\hline \multicolumn{5}{|c|}{$\begin{array}{l}\text { Mean values } \pm \text { standard deviations of all subjects ( } \mathrm{n}=118 \text { ). } \\
* \mathrm{p}<0.05 \text {; changes over time compared to baseline within groups } \\
\text { \# } \mathrm{p}<0.05 \text {; changes over time within groups } 3 \text { and } 12 \text { months weight maintenance compared to after } \\
1.5 \text { months of Very Low Calorie Diet } \\
{ }^{1} \text { The Baecke total activity index and its activity sub scores of sport, leisure time and work. } \\
{ }^{2} \text { A measure of cognitive restraint of the three-factor eating questionnaire (TFEQ); minimum score } 0 \text {, } \\
\text { maximum score } 21 \text {; cut-off point fort the Dutch population } 9 \text {. Values greater than } 9 \text { indicate cognitive } \\
\text { restraint eating. } \\
{ }^{3} \text { A measure of disinhibition or emotional eating of the TFEQ; minimum score } 0 \text {, maximum score } 14 \text {. }\end{array}$} \\
\hline
\end{tabular}

\section{Statistical analysis}

Statistical analysis took gender into account since reported papers showed significantly different outcomes between genders $(8,15)$. Associations between continuously distributed phenotype variables and genotype were assessed with factorial analysis of variance (ANOVA). First differences over time were determined with a 3-factor ANOVA repeated measures, separately for each of the PLIN polymorphisms. Differences between groups and changes over time were determined with factorial ANOVA and Scheffé-F or Fisher PLSD post hoc test (Statview SE GraphicsTM for Macintosh). $\chi 2$ statistics were used to assess possible deviation from Hardy-Weinberg equilibrium (Statview SE GraphicsTM for Macintosh). Haplotype analysis was conducted using the stochastic-EM algorithm (21). When homozygotes for the minor alleles did not differ significantly from the heterozygotes, they were taken together (PLIN 1, PLIN 4, PLIN 5). When homozygotes for the major alleles did not differ 
significantly from the heterozygotes those were taken together, and contrasted with homozygotes for the minor alleles (PLIN 6 and PLIN 7). All statistical tests were twosided, differences were considered significant at $\mathrm{p}<0.05$. Values are expressed as mean \pm standard deviation $(\mathrm{SD})$.

\section{RESULTS}

Body-weight loss during VLCD was $7.0 \pm 3.1 \mathrm{~kg}(\mathrm{p}<0.05)$, and body-weight regain was $3.7 \pm 1.4 \mathrm{~kg}(\mathrm{p}<0.05)(16)$. This coincided with changes in BMI, waist circumference, body composition and leptin concentrations (16; Table 10.1).

The overall genotype frequencies were in Hardy-Weinberg equilibrium $(\mathrm{p}<0.05)$. Linkage disequilibria were observed between PLIN 1 and PLIN 4: D'>0.9, and a pairwise $r^{2}$ of 0.72 ; and between PLIN 5 and PLIN 7: D' $>0.9$, and a pairwise $r^{2}$ of 0.85 . Figure 10.1 represents the location of PLIN polymorphisms and linkage disequilibrium.

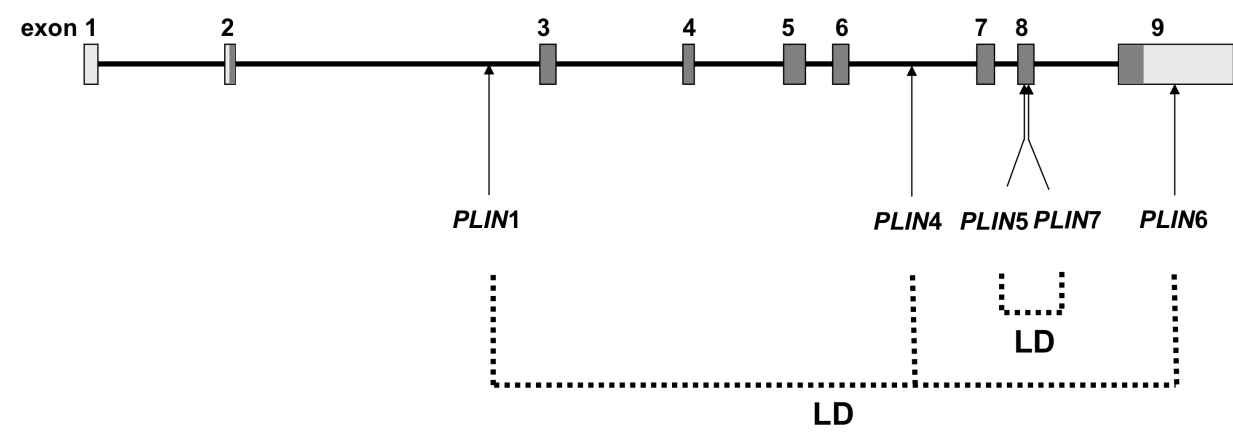

Figure 10.1. Architecture of the perilipin gene. All variants are silent or anonymous. Linkage disequilibria were present for PLIN1 and PLIN4: D'>0.9, $\mathrm{r}^{2}=0.72$; between PLIN5 and PLIN7: D' $>0.9, \mathrm{r}^{2}=0.85$.

Table 10.2 shows differences in the baseline characteristics of the subjects, as well as in changes of these characteristics over time, for the PLIN 1-4 haplotype; taking the minor alleles of the homozygotes together with the heterozygotes, since the phenotypes of the latter two categories did not differ significantly.

In men, body weight, BMI, waist circumference, body fat and leptin concentrations were significantly lower for this haplotype of PLIN 1 (C-alleles) and PLIN 4 (A-alleles) at baseline, and at every further time-point. In women it was the changes in characteristics over time, i.e. a greater weight loss and loss of fat mass was shown for the haplotype of PLIN 1 (C-alleles) and PLIN 4 (A-alleles). Taken together, the haplotype of PLIN 1-4 (minor alleles) was related to body-weight regulation at a lower level of body weight in the men as well in the women.

For the PLIN 6 genotypes body weight and body fat was lower at almost each time point (Table 10.3) for homozygotes of the minor allele (T/T) in the men; in the women only leptin concentrations were lower for the T/T genotype at baseline. 
Table 10.2. Subject characteristics of perilipin 1 (rs2289487) and perilin 4 (rs894160)

\begin{tabular}{|c|c|c|c|c|}
\hline & Baseline & $\begin{array}{l}\text { Change after } \\
1.5 \text { months }\end{array}$ & $\begin{array}{l}\text { Change after } \\
4.5 \text { months }\end{array}$ & $\begin{array}{l}\text { Change after } \\
13.5 \text { months }\end{array}$ \\
\hline Men $\quad n=42$ & & & & \\
\hline PLIN1 (C/C and T/C) & 20 & 20 & 20 & 20 \\
\hline \multicolumn{5}{|l|}{ PLIN4 (A/A and G/A) } \\
\hline $\operatorname{BMI}\left(\mathrm{kg} / \mathrm{m}^{2}\right)$ & $30.5 \pm 1.4 * *$ & $28.0 \pm 1.4 * *$ & $28.1 \pm 1.6^{* *}$ & $29.6 \pm 2.0 * *$ \\
\hline $\mathrm{BM}(\mathrm{kg})$ & $96.9 \pm 7.6 * *$ & $88.3 \pm 6.9 * *$ & $88.9 \pm 7.0 * *$ & $93.7 \pm 7.4 * *$ \\
\hline FFM (kg) & $67.3 \pm 6.9 * *$ & $63.3 \pm 6.5 * *$ & $65.0 \pm 6.7 * *$ & $67.0 \pm 6.9 * *$ \\
\hline FM (kg) & $29.7 \pm 5.0 * *$ & $25.0 \pm 4.8 * *$ & $23.9 \pm 4.1 * *$ & $26.7 \pm 4.7 * *$ \\
\hline FM (\%) & $30.7 \pm 3.9 * *$ & $28.3 \pm 3.7 * *$ & $26.9 \pm 3.7 * *$ & $28.5 \pm 3.8 * *$ \\
\hline Waist (cm) & $107 \pm 8 * *$ & $97 \pm 7 * *$ & $99 \pm 8 * *$ & $100 \pm 8 * *$ \\
\hline Leptin $(\mathrm{ng} / \mathrm{mL})$ & $12.2 \pm 6.3 * *$ & $4.1 \pm 1.8 * *$ & $6.9 \pm 2.0 * *$ & $9.7 \pm 3.8 * *$ \\
\hline PLIN1 (T/T) & 22 & 22 & 22 & 22 \\
\hline \multicolumn{5}{|l|}{ PLIN4 (G/G) } \\
\hline BMI $\left(\mathrm{kg} / \mathrm{m}^{2}\right)$ & $33.5 \pm 4.1 * *$ & $30.6 \pm 3.6 * *$ & $31.1 \pm 3.6 * *$ & $32.1 \pm 3.0 * *$ \\
\hline $\mathrm{BM}(\mathrm{kg})$ & $106.2 \pm 14.9 * *$ & $96.6 \pm 11.2 * *$ & $98.0 \pm 10.8 * *$ & $101.5 \pm 12.5 * *$ \\
\hline FFM (kg) & $69.1 \pm 10.1 * *$ & $66.9 \pm 9.4 * *$ & $70.5 \pm 9.6^{* *}$ & $70.8 \pm 9.4 * *$ \\
\hline FM (kg) & $37.1 \pm 6.9 * *$ & $31.0 \pm 5.1 * *$ & $27.5 \pm 6.5 * *$ & $30.7 \pm 5.7 * *$ \\
\hline FM $(\%)$ & $34.9 \pm 7.1 * *$ & $30.0 \pm 6.0 * *$ & $28.1 \pm 5.7 * *$ & $30.3 \pm 5.7 * *$ \\
\hline Waist (cm) & $115 \pm 13 * *$ & $106 \pm 12 * *$ & $106 \pm 12 * *$ & $107 \pm 12 * *$ \\
\hline Leptin (ng/mL) & $18.8 \pm 9.1 * *$ & $5.6 \pm 3.2 * *$ & $8.9 \pm 5.4 * *$ & $12.1 \pm 6.5^{* *}$ \\
\hline \multicolumn{5}{|l|}{ Women $\mathrm{n}=76$} \\
\hline PLIN1 (C/C and T/C) & 34 & 34 & 34 & 34 \\
\hline \multicolumn{5}{|l|}{ PLIN4 (A/A and G/A) } \\
\hline $\mathrm{BMI}\left(\mathrm{kg} / \mathrm{m}^{2}\right)$ & $30.3 \pm 2.1$ & $27.8 \pm 1.2$ & $288.2 \pm 2.1$ & $28.9 \pm 1.9 \#$ \\
\hline $\mathrm{BM}(\mathrm{kg})$ & $82.4 \pm 9.2$ & $76.0 \pm 7.8$ & $77.1 \pm 7.0$ & $78.8 \pm 7.5 \#$ \\
\hline FFM (kg) & $49.0 \pm 6.0$ & $48.5 \pm 4.4$ & $48.8 \pm 4.8$ & $48.2 \pm 4.7$ \\
\hline FM (kg) & $33.4 \pm 7.1$ & $27.5 \pm 5.2$ & $28.3 \pm 5.1$ & $30.6 \pm 6.6 \#$ \\
\hline FM $(\%)$ & $40.5 \pm 5.9$ & $36.2 \pm 5.8$ & $36.7 \pm 5.7$ & $38.8 \pm 6.0$ \\
\hline Waist $(\mathrm{cm})$ & $96 \pm 8$ & $89 \pm 7$ & $90 \pm 6$ & $90 \pm 6$ \\
\hline Leptin (ng/mL) & $34.0 \pm 13.8$ & $11.1 \pm 4.6$ & $17,7 \pm 7.6$ & $20.9 \pm 8.6$ \\
\hline PLIN1 (T/T) & 42 & 42 & 42 & 42 \\
\hline \multicolumn{5}{|l|}{ PLIN4 (G/G) } \\
\hline BMI $\left(\mathrm{kg} / \mathrm{m}^{2}\right)$ & $30.4 \pm 3.1$ & $28.0 \pm 2.8$ & $28.4 \pm 2.6$ & $29.5 \pm 1.9 \#$ \\
\hline BM (kg) & $84.2 \pm 9.4$ & $77.6 \pm 8.3$ & $78.8 \pm 7.8$ & $81.4 \pm 9.3 \#$ \\
\hline FFM (kg) & $51.5 \pm 6.3$ & $48.8 \pm 5.5$ & $51.2 \pm 5.8$ & $50.4 \pm 5.5$ \\
\hline FM (kg) & $32.7 \pm 7.5$ & $28.8 \pm 6.2$ & $27.6 \pm 6.8$ & $31.0 \pm 6.4 \#$ \\
\hline FM $(\%)$ & $38.8 \pm 7.9$ & $37.1 \pm 8.2$ & $35.0 \pm 7.7$ & $38.8 \pm 8.0$ \\
\hline Waist (cm) & $97 \pm 10$ & $91 \pm 9$ & $91 \pm 9$ & $92 \pm 9$ \\
\hline Leptin $(\mathrm{ng} / \mathrm{mL})$ & $30.3 \pm 15.1$ & $10.7 \pm 5.3$ & $18.8 \pm 9.7$ & $20.2 \pm 10.5$ \\
\hline
\end{tabular}

Mean values \pm standard deviations.

** $\mathrm{p}<0.01$; treatment between groups, haplotype PLIN1 (C/C and T/C) PLIN4 (A/A and G/A) vs. PLIN1 (T/T) PLIN4 (G/G).

\# $\mathrm{p}<0.05$; treatment over time compared to baseline between groups, haplotype PLIN1 (C/C and T/C) PLIN4 (A/A and G/A) vs. PLIN1 (T/T) PLIN4 (G/G), body-weight loss (3.6 vs -2.8kg) and fat mass loss

$(-2.8 \mathrm{vs}-1.7 \mathrm{~kg})$.

1.5 months of Very Low Calorie Diet.

23 and 12 months weight maintenance after 1.5 months of Very Low Calorie Diet. 
Table 10.3. Subject characteristics of perilipin 6 (rs 1052700)

\begin{tabular}{|c|c|c|c|c|}
\hline & Baseline & $\begin{array}{l}\text { Change after } \\
1.5 \text { months }\end{array}$ & $\begin{array}{l}\text { Change after } \\
4.5 \text { months }^{2}\end{array}$ & $\begin{array}{l}\text { Change after } \\
13.5 \text { months }^{2}\end{array}$ \\
\hline \multicolumn{5}{|l|}{ Men $\quad n=42$} \\
\hline PLIN6 (T/T) & 7 & 7 & 7 & 7 \\
\hline BMI $\left(\mathrm{kg} / \mathrm{m}^{2}\right)$ & $29.5 \pm 2.9 * *$ & $26.9 \pm 2.8 * *$ & $27.1 \pm 2.9 * *$ & $28.2 \pm 2.3 * *$ \\
\hline $\mathrm{BM}(\mathrm{kg})$ & $89.7 \pm 9.7 * *$ & $81.7 \pm 8.7 * *$ & $82.3 \pm 8.9 * *$ & $85.5 \pm 9.4 * *$ \\
\hline FFM (kg) & $63.3 \pm 6.8 * *$ & $58.8 \pm 5.9 * *$ & $62.9 \pm 6.6 * *$ & $66.1 \pm 6.4 * *$ \\
\hline FM (kg) & $26.3 \pm 3.7 * *$ & $22.9 \pm 3.1 * *$ & $19.4 \pm 2.4 * *$ & $19.4 \pm 2.4 * *$ \\
\hline FM (\%) & $28.7 \pm 3.2 * *$ & $27.9 \pm 3.1$ & $23.8 \pm 3.0$ & $24.2 \pm 3.2 * *$ \\
\hline Waist (cm) & $104.6 \pm 10.1 * *$ & $94.9 \pm 9.7 * *$ & $95.1 \pm 9.3 * *$ & $97.1 \pm 9.3$ \\
\hline Leptin $(\mathrm{ng} / \mathrm{mL})$ & $8.8 \pm 4.4 * *$ & $3.1 \pm 2.3$ & $6.0 \pm 2.5$ & $6.6 \pm 3.8 * *$ \\
\hline PLIN6 (A/A and T/A) & 35 & 35 & 35 & 35 \\
\hline $\mathrm{BMI}\left(\mathrm{kg} / \mathrm{m}^{2}\right)$ & $32.8 \pm 3.9 * *$ & $29.7 \pm 3.3^{* *}$ & $30.1 \pm 3.2 * *$ & $31.5 \pm 3.2 * *$ \\
\hline $\mathrm{BM}(\mathrm{kg})$ & $105.0 \pm 9.4 * *$ & $95.5 \pm 9.2 * *$ & $96.5 \pm 8.9 * *$ & $100.8 \pm 9.6 * *$ \\
\hline FFM (kg) & $69.0 \pm 8.9 * *$ & $66.9 \pm 6.5 * *$ & $70.6 \pm 6.8 * *$ & $70.4 \pm 7.3 * *$ \\
\hline FM (kg) & $35.7 \pm 4.5 * *$ & $28.6 \pm 3.2 * *$ & $25.9 \pm 3.3 * *$ & $30.3 \pm 3.3 * *$ \\
\hline FM $(\%)$ & $33.5 \pm 4.2 * *$ & $29.2 \pm 3.1$ & $25.1 \pm 3.3$ & $29.3 \pm 3.1 * *$ \\
\hline Waist (cm) & $112 \pm 9 * *$ & $103 \pm 9 * *$ & $103 \pm 10 * *$ & $105 \pm 9$ \\
\hline Leptin (ng/mL) & $17.2 \pm 8.3 * *$ & $5.1 \pm 2.2$ & $8.4 \pm 4.6$ & $12.1 \pm 5.2 * *$ \\
\hline \multicolumn{5}{|l|}{ Women $n=76$} \\
\hline PLIN6 (T/T) & 10 & 10 & 10 & 10 \\
\hline BMI $\left(\mathrm{kg} / \mathrm{m}^{2}\right)$ & $30.3 \pm 3.5$ & $28.1 \pm 4.9$ & $28.0 \pm 4.6$ & $29.2 \pm 4.6$ \\
\hline BM (kg) & $80.9 \pm 8.0$ & $75.1 \pm 7.7$ & $74.9 \pm 7.5$ & $78.1 \pm 7.8$ \\
\hline FFM (kg) & $47.8 \pm 4.8$ & $45.6 \pm 4.7$ & $47.4 \pm 4.8$ & $47.1 \pm 4.6$ \\
\hline FM (kg) & $33.1 \pm 3.2$ & $29.5 \pm 3.3$ & $26.6 \pm 2.7$ & $31.0 \pm 3.4$ \\
\hline FM $(\%)$ & $40.9 \pm 4.3$ & $39.3 \pm 4.2$ & $35.9 \pm 4.1$ & $39.5 \pm 4.2$ \\
\hline Waist (cm) & $98 \pm 10$ & $91 \pm 9$ & $91 \pm 10$ & $92 \pm 10$ \\
\hline Leptin $(\mathrm{ng} / \mathrm{mL})$ & $30.2 \pm 15.1 *$ & $11.3 \pm 5.9$ & $17.2 \pm 8.1$ & $21.8 \pm 10.4$ \\
\hline PLIN6 (A/A and T/A) & 66 & 66 & 66 & 66 \\
\hline BMI $\left(\mathrm{kg} / \mathrm{m}^{2}\right)$ & $30.3 \pm 3.4$ & $28.21 \pm 2.7$ & $28.2 \pm 3.3$ & $29.2 \pm 3.7$ \\
\hline $\mathrm{BM}(\mathrm{kg})$ & $83.7 \pm 8.1$ & $77.6 \pm 7.8$ & $78.0 \pm 7.5$ & $80.5 \pm 8.1$ \\
\hline FFM (kg) & $50.7 \pm 5.3$ & $48.3 \pm 4.8$ & $49.9 \pm 4.8$ & $49.4 \pm 4.6$ \\
\hline FM (kg) & $34.4 \pm 4.3$ & $29.2 \pm 4.1$ & $27.8 \pm 3.3$ & $31.0 \pm 3.6$ \\
\hline FM $(\%)$ & $39.7 \pm 4.1$ & $37.5 \pm 3.7$ & $34.8 \pm 3.4$ & $38.8 \pm 3.6$ \\
\hline Waist (cm) & $97 \pm 10$ & $90 \pm 10$ & $91 \pm 9$ & $92 \pm 9$ \\
\hline Leptin $(\mathrm{ng} / \mathrm{mL})$ & $33.0 \pm 17.2$ & $11.2 \pm 6.2$ & $18.4 \pm 8.1$ & $20.1 \pm 10.5$ \\
\hline \multicolumn{5}{|c|}{$\begin{array}{l}\text { Mean values } \pm \text { standard deviations. } \\
* \mathrm{p}<0.0 * * \mathrm{p}<0.01 \text {; treatment between groups, PLIN6 (T/T) vs. (A/A and T/A). } \\
11.5 \text { months of Very Low Calorie Diet. }\end{array}$} \\
\hline
\end{tabular}

The haplotype of PLIN 5-7 consisting of the combination of the minor alleles $(\mathrm{G} / \mathrm{G}$ and $\mathrm{A} / \mathrm{G}$ of PLIN 5 and A/A of PLIN 7), resulting in 5 subjects in the men, and 8 in the women, showed no significant differences in anthropometric characteristics in the men, and a significantly larger reduction of fat mass $5.9 \pm 0.6 \mathrm{~kg}$ vs. $3.1 \pm 0.4 \mathrm{~kg}$, fat percentage $5.5 \pm 0.6 \%$ vs. $2.2 \pm 0.2 \%$, and leptin $20.5 \pm 10.8 \mathrm{ng} / \mathrm{mL}$ vs. $12.9 \pm 6.7 \mathrm{ng} / \mathrm{mL}$ over time in the women $(\mathrm{p}<0.05)$. Again body-weight regulation at a lower level was shown as phenotype related to the minor alleles genotype. 


\section{DISCUSSION}

Our observations on the polymorphisms of the PLIN gene confirm some previous findings and lead to new findings with respect to responses to interventions regarding body-weight loss and body-weight maintenance. Moreover, we added a new polymorphism, namely PLIN 7 to the already described polymorphisms of PLIN. Furthermore, instead of separated analyses for each individual PLIN genotype, we found two haplotypes, namely PLIN 1-4; PLIN 5-7, and analyzed the phenotypes according to the haplotypes.

The haplotype of PLIN 1-4 consisting of the combination of the minor alleles $(\mathrm{C} / \mathrm{C}$ and T/C of PLIN 1) and (A/A and G/A of PLIN 4), showed significantly lower body weight and fat mass in the men and larger body-weight loss and fat loss over time in the women. In the men, this represents a permanent trait. In the women a greater weight loss and loss of fat mass over time shows flexibility and responsiveness to weight-loss interventions. Also the association with waist circumference is of particular importance, since this means that it is especially associated with one of the metabolic syndrome factors, namely visceral obesity (21). Before, it was reported that a lower BMI and waist-hip ratio, as well as plasma glucose and triacylglycerol concentrations were associated with PLIN4 G>A in women, but not in men (8). The study by Qi et al., (8) in a Spanish population, reported a lower BMI, lower waist-to-hip ratio, plasma glucose, and triacylglycerol concentrations in the women, for A-carriers at PLIN 4, while no significant associations with these obesity-related phenotypes were found in men. Gender differences between our observations, and those by Qi et al., (8) are mainly due to the differences in the populations and the ranges of BMI involved. The effects that Qi et al. found in the women of a Spanish population were due to the lower BMI's, i.e. $25.2 \pm 0.3 \mathrm{~kg} / \mathrm{m}^{2}$ compared to $26.1 \pm 0.2 \mathrm{~kg} / \mathrm{m}^{2}$; the same applies to the lack of effects they found in the men, i.e. $26.5 \pm 0.2 \mathrm{~kg} / \mathrm{m}^{2}$ vs. $26.3 \pm 0.2 \mathrm{~kg} / \mathrm{m}^{2}$. Also, they did not measure body composition, so their observations did not take body fat into account. The statistical significance they report upon such small differences between the genotype groups in the women is due to the large number of subjects. In the women we found no significant difference in BMI, and no differences in fatpercentage. However, in our smaller population we already found a larger difference in BMI in men, supported by differences in body composition, related to the minor alleles of the PLINI 1-4 haplotype.

Also Corella et al. (15) showed that with PLIN $4 \mathrm{G}>\mathrm{A}$ baseline body weight was lower, for men as well as women. However, the resistance to body-weight loss in particular genotypes that Corella et al. (15) observed was not confirmed in our study. Our subjects lost $7 \pm 3.1 \mathrm{~kg}$ during the first six weeks easily, without any resistance. Furthermore, the lower values of bodyweight, BMI, and waist circumference associated with the A/A and G/A genotype at baseline, were still apparent after both the weight-loss and weight-maintenance periods. It is likely, that the main problem in the study by Corella et al., (15) is due to compliance to the energy-restricted diet. In our population no diet was prescribed, subjects followed their own strategies, supported by information from our laboratory.

In line with our results, Kang et al. (22) reported that PLIN 4 was associated with weight gain from rosaglitazone treatment, in which the AA genotype showed less increase in body weight than other genotypes. Mottagui-Tabar also reported a more 
rapid basal and noradrenalin induced lipolysis with the AA genotype (9). Thus with respect to the PLIN 1-4 haplotype, we conclude that it is associated with body-weight regulation and metabolic syndrome aspects, in favor of the minor alleles, in men as observed in our study. For the women we observed a greater responsiveness to treatment with this haplotype; a possible further effect still needs to be confirmed.

Table 10.4. Subject characteristics of perilipin 5 (rs2304795) and perilin 7 (rs2304796)

\begin{tabular}{|c|c|c|c|c|}
\hline & Baseline & $\begin{array}{l}\text { Change after } \\
1.5 \text { months }^{1}\end{array}$ & $\begin{array}{l}\text { Change after } \\
4.5 \text { months }^{2}\end{array}$ & $\begin{array}{l}\text { Change after } \\
13.5 \text { months }^{2}\end{array}$ \\
\hline \multicolumn{5}{|l|}{ Men $\quad n=42$} \\
\hline PLIN5 (G/G and A/G) & 5 & 5 & 5 & 5 \\
\hline \multicolumn{5}{|l|}{ PLIN7 (A/A) } \\
\hline BMI $\left(\mathrm{kg} / \mathrm{m}^{2}\right)$ & $32.7 \pm 3.6$ & $30.3 \pm 3.7$ & $31.1 \pm 3.4$ & $32.1 \pm 3.4$ \\
\hline $\mathrm{BM}(\mathrm{kg})$ & $100.6 \pm 10.5$ & $93.3 \pm 9.7$ & $95.7 \pm 9.8$ & $99.0 \pm 9.9$ \\
\hline FFM (kg) & $71.6 \pm 7.3$ & $68.2 \pm 7.3$ & $70.7 \pm 7.2$ & $71.0 \pm 7.2$ \\
\hline FM (kg) & $29.0 \pm 2.7$ & $25.2 \pm 3.1$ & $25.4 \pm 2.9$ & $28.0 \pm 3.5$ \\
\hline FM $(\%)$ & $28.9 \pm 2.7$ & $27.2 \pm 2.3$ & $26.7 \pm 2.7$ & $28.2 \pm 2.7$ \\
\hline Waist (cm) & $113 \pm 11$ & $104 \pm 11$ & $106 \pm 11$ & $107 \pm 11$ \\
\hline Leptin $(\mathrm{ng} / \mathrm{mL})$ & $12.7 \pm 6.9$ & $3.9 \pm 1.8$ & $6.9 \pm 3.2$ & $9.8 \pm 4.6$ \\
\hline PLIN5 (A/A) & 37 & 37 & 37 & 37 \\
\hline \multicolumn{5}{|l|}{ PLIN7 (G/G and A/G) } \\
\hline BMI $\left(\mathrm{kg} / \mathrm{m}^{2}\right)$ & $32.2 \pm 3.0$ & $29.2 \pm 24$ & $29.5 \pm 2.6$ & $30.8 \pm 2.8$ \\
\hline $\mathrm{BM}(\mathrm{kg})$ & $102.7 \pm 10.3$ & $93.2 \pm 9.7$ & $94.0 \pm 9.5$ & $98.2 \pm 9.1$ \\
\hline FFM (kg) & $68.6 \pm 6.4$ & $65.5 \pm 6.4$ & $69.4 \pm 6.7$ & $69.7 \pm 6.4$ \\
\hline FM (kg) & $34.3 \pm 3.5$ & $27.8 \pm 2.4$ & $24.6 \pm 2.0$ & $28.5 \pm 2.5$ \\
\hline FM $(\%)$ & $32.9 \pm 3.3$ & $29.2 \pm 3.1$ & $27.5 \pm 2.6$ & $28.5 \pm 2.7$ \\
\hline Waist (cm) & $111 \pm 10$ & $101 \pm 9$ & $101 \pm 9$ & $103 \pm 9$ \\
\hline Leptin (ng/mL) & $16.5 \pm 8.1$ & $4.8 \pm 2.0$ & $8.0 \pm 4.6$ & $11.2 \pm 5.0$ \\
\hline \multicolumn{5}{|l|}{ Women $n=76$} \\
\hline $\operatorname{PLIN} 5(\mathrm{G} / \mathrm{G}$ and $\mathrm{A} / \mathrm{G})$ & 8 & 8 & 8 & 8 \\
\hline \multicolumn{5}{|l|}{ PLIN7 (A/A) } \\
\hline BMI $\left(\mathrm{kg} / \mathrm{m}^{2}\right)$ & $30.0 \pm 2.6$ & $27.6 \pm 3.1$ & $27.5 \pm 2.5$ & $28.3 \pm 3.6$ \\
\hline $\mathrm{BM}(\mathrm{kg})$ & $83.0 \pm 8.8$ & $76.5 \pm 8.3$ & $76.1 \pm 8.1$ & $78.3 \pm 8.2$ \\
\hline FFM (kg) & $49.1 \pm 5.7$ & $47.3 \pm 5.4$ & $50.0 \pm 5.1$ & $50.0 \pm 5.6 \#$ \\
\hline FM (kg) & $33.9 \pm 3.8$ & $29.2 \pm 3.3$ & $26.1 \pm 3.6$ & $28.0 \pm 3.7 \#$ \\
\hline FM $(\%)$ & $42.5 \pm 4.3$ & $38.7 \pm 3.5$ & $34.7 \pm 3.7$ & $37.0 \pm 3.3 \#$ \\
\hline Waist $(\mathrm{cm})$ & $97 \pm 10$ & $92 \pm 10$ & $92 \pm 9$ & $92 \pm 10$ \\
\hline Leptin (ng/mL) & $37.7 \pm 18.3$ & $11.4 \pm 5.6$ & $17.3 \pm 8.6$ & $17.1 \pm 8.5 \#$ \\
\hline PLIN5 (A/A) & 67 & 67 & 67 & 67 \\
\hline \multicolumn{5}{|l|}{ PLIN7 (G/G and A/G) } \\
\hline BMI $\left(\mathrm{kg} / \mathrm{m}^{2}\right)$ & $30.3 \pm 3.5$ & $28.1 \pm 2.7$ & $28.3 \pm 2.4$ & $29.3 \pm 3.3$ \\
\hline $\mathrm{BM}(\mathrm{kg})$ & $83.6 \pm 8.5$ & $77.4 \pm 7.5$ & $77.9 \pm 8.1$ & $81.1 \pm 8.1$ \\
\hline FFM (kg) & $49.7 \pm 5.1$ & $47.6 \pm 4.7$ & $49.4 \pm 4.2$ & $48.9 \pm 5.0 \#$ \\
\hline FM (kg) & $33.6 \pm 3.3$ & $29.7 \pm 2.7$ & $28.4 \pm 2.7$ & $31.6 \pm 2.3 \#$ \\
\hline FM $(\%)$ & $39.1 \pm 3.2$ & $36.9 \pm 3.4$ & $34.9 \pm 3.7$ & $37.7 \pm 3.4 \#$ \\
\hline Waist (cm) & $96 \pm 9$ & $90 \pm 8$ & $91 \pm 8$ & $91 \pm 9$ \\
\hline Leptin (ng/mL) & $32.6 \pm 14.1$ & $11.2 \pm 4.4$ & $18.3 \pm 8.1$ & $20.2 \pm 10.0 \#$ \\
\hline $\begin{array}{l}\text { Mean values } \pm \text { standard } \\
\# \text { p }<0.05 \text {; treatment or } \\
\text { A/G) PLIN7 (A/A) vs. } \\
11.5 \text { months of Very L }\end{array}$ & $\begin{array}{l}\text { eviations. } \\
\text { time compa } \\
\text { IN5 (A/A) PI } \\
\text { Calorie Diet }\end{array}$ & $\begin{array}{l}\text { to baseline bet } \\
\text { (G/G and } A / G\end{array}$ & groups, hapl & PLIN5 (G/G \\
\hline
\end{tabular}


The PLIN 6 genotypes showed that in homozygotes for the minor alleles (T/T) in the men, body weight and body fat was lower at almost each time point; in the women only leptin concentrations were lower in the T/T genotype at baseline. This seems to be different from the findings reported by Qi et al. (13), who found an association of the haplotype of PLIN 5 and PLIN $6 \mathrm{~A}>\mathrm{T}$ with fat percentage and waist circumference in women. Here the difference between the observations is likely to be due to the haplotype approach that Qi et al., (13) applied, consisting of PLIN 5 and PLIN 6, whereas we found a PLIN 5-7 haplotype. Moreover, Corella et al. (24) observed dietgene interactions between PLIN6 $\mathrm{A}>\mathrm{T}$ and HOMA-index, a measure of insulin sensitivity.

With respect to PLIN 7 no previous observations regarding body-weight or bodyweight regulation have been reported. The haplotype of PLIN 5-7 consisting of the combination of the minor alleles (G/G and A/G of PLIN 5 and A/A of PLIN 7) showed no significant differences in the men, and a significantly larger reduction of fat mass, fat percentage, and leptin concentrations over time in women.

The observations reported above, provide evidence for a differential response to a weight-loss weight-maintenance intervention supported by a differential effect on body composition, especially body fat, with a role of the PLIN genotype therein. The predominant isoform is expressed in adipocytes and involved in regulating fat storage, primarily by modulating HSL activity mediating triacylglycerol hydrolysis (3). This is supported by the effect on body fat storage of the rodent plin -/- phenotype, namely a reduction of stored adipose mass, normal body-weight despite increased food intake, increased muscle mass, increased metabolic rate and oxygen consumption and nearmaximal lipolysis (in adipocytes) under basal conditions $(4,5)$. Basal lipolysis is related to activated HSL (6), despite increase in plasma free fatty acid levels, which is compensated by free fatty acid utilization.

Taken together, we found differential genotypic effects on body weight and bodyweight regulation, for the PLIN 1-4 haplotype, PLIN 6, and the PLIN 5-7 haplotype, in that the minor alleles supported body weight regulation at a lower level of body weight than the major alleles did. A remarkable sex difference was observed, in that the differences in anthropometrical characteristics in men were mostly present at baseline, and remained throughout the study, whereas in women it was the larger size of reaction on the diet that was underscored by the minor alleles of these PLIN polymorphisms.

In conclusion, the PLIN $(1-4,6,5-7)$ locus appears as a genetic influencer of obesity risk in humans, with comparable sensitivity in women and men. In addition, genetic variation for PLIN 1-4 and PLIN 5-7 appears to influence body-weight management in response to a diet. The differential response to a weight-loss weightmaintenance intervention was accompanied by a differential effect on body composition.

\section{ACKNOWLEDGEMENTS}

We thank Dr. Arnold Kester for statistical advice. The study was sponsored by Unilever Corporate Research. 


\section{REFERENCES}

1. Lu et al. The murine perilipin gene: the lipid droplet-associated perilipins derive from tissuespecific, mRNA splice variants and define a gene family of ancient origin. (2001) Mamm. Genome. 2001;12:741-749.

2. Londos C, Brasaemle DL, Schulz CJ, Adler-Wailes DC, Levin DM, Kimmel AR, Rondinonen CM. On the control of lipolysis in adipocytes. Ann. NY Acad. Sci. 1999;892:155-68.

3. Greenberg AS, Egan JJ, Wek SA, Moos MC, Londos C, Kimmel AR. Isolation of cDNAs for perilipins A and B: Sequence and experession of lipid droplet-associated proteins of adipocytes. Proc. Natl. Acad. Sci.2003;90:12035-12039.

4. Martinez-Botas J, Anderson JB, Tessier D, Lapillonne A, Chang H-J, Quast MJ, Gorenstein D, Chen K-H, Chan L. Absence of perilipin results in leanness and reverses obesity in Leprdb/db mice. Nature Genetics 2000; 26:474-479.

5. Tansey JT, Sztalryd C, Gruia-Gray J, Roush DL, Zee JV, Gavrilova O, reitman ML, Deng C-X. Li C. Kimmel AR, Londos C. Perilipin abalation results in a lean mouse with aberrant adipocyte lipolysis, enhanced leptin production, and resistance to diet-induced obesity. Proc. Natl. Acad. Sci.2001;98:6494-6499.

6. Tansey JT, Sztalryd C, Hlavin EM, Kimmel AR, Londos C. The central role of perilipin a in lipid metabolism and adipocyte lipolysis. IUBMB Life 2004;56:379-85.

7. Saha PK, Kojima H, Martinez Botas J, Sunehag AL, Chan L. Metabolic adaptions in the absence of perilipin. Journ Biol Chem 2004;279:35150-35158.

8. Qi L, Corella D, Sorli JV, Portoles O, Shen H, Coltell O, Gordoy D, Greenberg AS, Ordovas JM. Genetic variation at the perilipin (PLIN) locus is associated with obesity-related phenotypes in white women. Clin. Genet.2004a; 66:299-310.

9. Mottagui-Tabar S, Ryden M, Lofgren P, Faulds G, Hoffstedt J, Brookes AJ et al. Evidence for an important role of perilipin in the regulation of human adipocyte lipolysis. Diabetologia 2003;46:789-797.

10. Perez-Martinez P, Yiannakouris N, Lopez-Miranda J, Arnett D, Tsai M, Galan E, Straka R, Delgado-Lista J, Province M, Ruano J, Borecki I, Hixson J, Garcia-Bailo B, Perez-Jimenez Fm, Ordovas JM. Postprandial triacylglycerol metabolism is modified by the presence of genetic variation at the perilipin (PLIN) locus in 2 white populations. Am J Clin Nutr 2008;87:744-52.

11. Jang Y, Kim OY, Lee SJ, Chae JS, Park S, Cho H, Lee JE, Ordovas JM. Genetic variation at the perilipin locus is associated with changes in serum free fatty acids and abdominal fat following mild weight loss. Int J Obes Relat Metab Disord 2006;30:1601-8.

12. Qi L, Zhang C, Greenberg A, Hu FB. Common variations in perilipin gene, central obesity, and risk of type 2 diabetes in US women. Obesity 2008;16:1061-1065.

13. Qi L, Shen H, Larson I, Schaefer EJ, Greenberg AS, Tregouet Da et al. Gender-specific association of a perilipin gene haplotype with obesity risk in a White population. Obesity Research 2004b;12:1758-1765.

14. Meirhaeghe A, Thomas S, Ancot F, Cotel D, Arveiler D, Ferrieres J, Amouyel P. Study of the impact of perilipin polymorphismsin a French population. J Negat Results Biomed 2006;5:1017.

15. Corella D, Qi L, Sorli JV, Godoy D, Portoles O, Coltell O, Greenberg AS, Ordovas JM. Obese subjects carrying the $11482 \mathrm{G}>\mathrm{A}$ polymorphism at the perilipin (PLIN) locus are resistant to weight loss following dietary energy restriction. JCEM 2005;90:5121-6.

16. Vogels N, Westerterp-Plantenga MS. Categorical strategies on subject characyeristics of dietary restraint and physical activity, for weight maintenance. Int $\mathrm{J}$ Obes Relat Metab Disord 2005;29:849-57.

17. Vogels N, Mariman ECM, Bouwman FG, Kester ADM, Diepvens K, Westertterp-Plantenga MS. Relationship of weight maintenance and dietary restraint witth peroxisome proliferator-activated receptor g2, glucocorticoid receptor and ciliary neurotrophic factor polymorphisms. Am J Clin Nutr 2005;82:740-46. 
18. van Marken Lichtenbelt WD, Westerterp KR, Wouters L. Deuterium dilution as a method for determining total body water: effect of test protocol and sampling time. Br J Nutr 1994;72:4917.

19. Schoeller DA, van Santen E, Peterson DW, Dietz W, Jaspan J, Klein PD. Total body water measurement in humans with $18 \mathrm{O}$ and 2H labeled water. Am J Clin Nutr 1980;33:2686-93.

20. Westerterp KR, Wouters L, van Marken Lichtenbelt WD. The Maastricht protocol for the measurement of body composition and energy expenditure with labeled water. Obes Res 1995;3 Suppl 1:49-57.

21. Tregouet DA, Escolano S, Tiret L, Mallet A, Golmard JL. A new algorithm for haplotype-based association análisis: the Stochastic-EM algorithm. Ann Hum Genet 2004;68:165-177.

22. Sjostrom L, Rissanen A, Andersen T, et al. Randomised placebo-controlled trial of orlistat for weight loss and prevention of weight regain in obese patients. European Multicentre Orlistat Satudy Group. Lancet 1998;352:167-72.

23. Kang ES, Park SE, Han SJ, Kim SH, Nam CM, Ahn CW, Cha BS, Kim KS, Lee HC. LPIN1 genetic variation is associated with rosiglitazone response in type 2 diabetic patients. Mol Genet Metab. 2008;95(1-2):96-100.

24. Corella D, Qi L, Tai ES, et al. Perilipin gene variation determines higher susceptibility to insulin resistance in Asian women when consuming a high-saturated fat, low-carbohydrate diet. Diabetes Care 2006;29:1313-9. 



\section{GENERAL DISCUSSION}




\section{DIETARY APPROACH TO TARGET OBESITY}

The diet is one of the major factors that play a role in the obesity epidemic. Regarding the dietary impact on body weight development; energy content, energy density, macronutrient composition, presence of micronutrients and additives, all potentially influence the daily balance between energy intake and energy expenditure, which determines body-weight development over time. Traditionally, increase in body weight over time resulting in overweight (BMI of 25 to $29.9 \mathrm{~kg} / \mathrm{m}^{2}$ ), obesity (BMI of 30 to $34.9 \mathrm{~kg} / \mathrm{m}^{2}$ ), and severe obesity (BMI of 35 to $39.9 \mathrm{~kg} / \mathrm{m}^{2}$ ) is targeted with bouts of energy restriction during lifetime. Moreover, these energy-restricted diets mainly focused on reducing fat or carbohydrate intake, as fat is related to its high energy content, i.e. $37 \mathrm{~kJ} / \mathrm{g}$ for fat vs. $17 \mathrm{~kJ} / \mathrm{g}$ for carbohydrate and protein, and carbohydrate is widely used in refined products because of its sweetening capacity. Furthermore, fatand carbohydrate-rich foods are more accessible to consumers because of their high palatability. The typical Western-diet consists of 30 to $35 \%$ of energy from fat, 50 to $55 \%$ of energy from carbohydrate, and 10 to $15 \%$ of energy from protein.

The research in this thesis was focused on effects of macronutrient composition of the diet, especially protein, and body composition on energy intake and energy expenditure in relation to prevention and short- and long-term treatment of overweight and obesity. A supra-sustained-protein diet in energy balance results in a more favorable body composition, i.e. an increased fat free mass at the cost of fat mass, without the trigger of energy restriction or increase in physical activity. The increase in protein intake of the diet increases stimulated fat oxidation, as a function of change in protein intake. Furthermore, a supra-sustained-protein diet vs. a sustained-protein diet improves sparing of fat free mass in combination with sustained resting energy expenditure as a function of fat free mass during loss of body weight. Contrast in the level of the amino acid tryptophan, i.e. alpha-lactalbumin protein vs. milk protein, does not influence these results. A combined supra-sustained-protein low-carbohydrate diet reduces body weight and fat percentage synergistically most during energy restriction, followed by an elevated-protein diet irrespective of the carbohydrate content, while a low-carbohydrate diet only reduces body weight and fat percentage more in the presence of elevated-protein. Furthermore, the supra-sustained-protein normal carbohydrate diet is most successful in maintaining the reduced body weight. The differential response to a weight-loss weight-maintenance intervention is accompanied by a differential effect on body composition interacted by the genetic background. Genetic variation for perilipin 1-4 and 5-7 haplotypes appears to influence body-weight management in response to the diet. Regarding short-term effects of dietary components, preloads containing sucrose, HFCS, or milk do not differ in satiety, compensation, or overconsumption despite differences in biochemical properties and differences in mechanisms underlying satiety in relation to GLP-1 and ghrelin release.

\section{PROTEIN INTAKE REGULATION INSTEAD OF ENERGY INTAKE REGULATION?}

Oppositely to the traditional attention paid to fat and carbohydrate, energy intake seems to be a reflection of protein intake. The response to an unbalanced diet, relative to the usual daily intake target, is to prioritize protein intake. Individuals overeat 
carbohydrate and fat of a diet containing a lower ratio of protein to carbohydrate and fat until the daily intake target amount of protein is ingested, and not the target of total energy intake, where there would still be a deficit of protein intake. In contrast, individuals do not overconsume energy when the diet has an increased protein to carbohydrate and fat ratio. So, this protein leverage hypothesis (1) provides a mechanism for why protein intake is more important than fat or carbohydrate in diet regimes to promote body-weight loss. More traditional low-fat or low-carbohydrate energy-restricted diets reduce the protein intake during energy restriction and thereby, based on the protein leverage hypothesis, create a drive to overconsume the diet with its low protein to carbohydrate and fat ratio until the habitual-protein intake level is reached. Therefore, perceiving the amount of protein seems to be the motor behind perceiving energy intake. Furthermore, evidence suggests that protein balance is finely regulated over a day, in contrast to energy balance, which is roughly regulated over a few days to a week (1).

A long-term approach of successful body-weight loss and weight maintenance, i.e. individuals that are compliant to the restriction of energy, is supported by short-term effects of the diet. Short-term effects of a diet are complex as they are depending on multiple factors such as energy content, energy density, physiological state, macronutrient and micronutrient composition, and palatability of the food. For example, satiety, compensation, and overconsumption of liquid preloads containing sucrose, HFCS, or milk are not different despite differences in biochemical properties; such as osmotic pressure, absorption, thermogenic response and liver metabolism, and differences in mechanisms underlying satiety; such as nutrient-related hormones ghrelin and GLP-1 or plasma concentrations of glucose and insulin. Nevertheless, there is a lot of evidence of short-term differences between macronutrients related to energy intake and energy expenditure supporting long-term body weight management by increasing compliance to the diet.

One of the aspects of proteins that increase compliance to the diet is the satiating capacity of proteins, i.e. proteins are the most satiating of all macronutrients (2-8). Thus, increased hunger suppression before and enhanced satiety after a meal and throughout the day help to reduce daily energy intake resulting in a negative energy balance over time. Moreover, the satiety effect of an elevated-protein diet can be reinforced in combination with low-carbohydrate intake. A mechanism underscoring the very strong satiety effect of the sustained-protein low-carbohydrate diet may be based upon the ketogenic state created by this diet, thereby increasing postprandial fat oxidation in combination with the formation of ketone bodies such as betahydroxybutyrate (9), that is related to appetite-reduction and greater reduction of body weight in energy-restricted humans (10-12). Furthermore, the relatively high-fat intake during this diet may result in increased postprandial fat oxidation, increased fat oxidation reducing appetite (13), whereas inhibition of fat oxidation increases food intake (14).

Proteins also support compliance to the diet via their higher thermogenic response or diet induced thermogenesis, after a meal compared to carbohydrates and fat $(7,15-$ 19), resulting into increased 24-hour energy expenditure and thereby supporting a negative energy balance (20). This elevated thermogenesis is able to facilitate the reduction of body weight as it is sustained despite weight loss (21), and furthermore 
results in a limited weight gain during overfeeding $(22,23)$, and therefore prevent the so-called 'yo-yo-effect'. The low energy efficiency of proteins is possibly reached by increased oxygen consumption $(24,25)$ mediated by the high ATP costs of postprandial protein synthesis $(26,27)$. The effects of proteins on energy intake and energy expenditure help to optimize compliance to energy-restricted diets to result in optimal body-weight loss $(28,29)$ and weight maintenance thereafter. Compliance to the diet is furthermore reinforced by increase in dietary restraint, a measure of control of food intake by thought and will-power, decrease in disinhibition of control, an incidental inability to resist eating cues, and decrease in subjective feeling of hunger, all related to reduction of body weight.

\section{FAT FREE MASS REGULATION IN STEAD OF BODY WEIGHT REGULATION?}

Obesity is a result of a positive energy balance over time, occurring when energy intake exceeds energy expenditure. Dietary interventions to target obesity would therefore ideally support both a decrease in energy intake and an increase in energy expenditure. Energy intake is mainly influenced by appetite and satiety whereas energy expenditure is mainly influenced by the component resting energy expenditure determined by body composition and the component diet induced thermogenesis, not taking the component of physical activity induced energy expenditure into account. Optimal body-weight maintenance after successful weight loss is opposed by the drop in resting energy expenditure, due to the loss of body mass during energy restriction. Resting energy expenditure decreases even more than predicted from the amount of body loss. Therefore, as fat free mass is the main determinant of resting metabolic rate (30) as well as 24-hour energy expenditure (31), preservation of fat free mass during the loss of body weight is crucial to prevent a positive energy balance after bodyweight loss. In this respect, elevated protein diets are more successful compared to control diets in sparing of fat free mass during energy restriction $(3-5,7,16,29,32-$ 36).

Sparing of fat free mass via muscle-protein synthesis is a result of nitrogen retention, an acute response to a protein rich meal (37-40). In addition, elevated protein diets change substrate oxidation, in that more fat is oxidized than consumed resulting in a negative fat balance, thereby facilitating the reduction of fat mass $(24,37)$. Even, body-weight regain after weight loss was slower when the body composition of the weight regained consisted of a greater fat free mass due to increased protein intake $(5$, $16,33,34,41-43)$. Thus, the shift into a more optimal body composition, i.e. a higher ratio of fat free mass over fat mass to sustain energy expenditure during the negative energy balance and weight maintenance thereafter could increase long-term effects of a dietary weight reduction approach.

The differential response to a weight-loss weight-maintenance intervention interacts with the genetic background of the individual. The perilipin (1-4, 6, 5-7) locus appears as a genetic influencer of obesity risk in humans. The minor alleles support body weight regulation at a lower level of body weight. In addition, genetic variation for the haplotypes PLIN 1-4 and PLIN 5-7 appears to influence body-weight management in response to a diet, supported by a differential effect on body composition, especially body fat. Support for these findings is the fact that the 
predominant isoform of perilipin is expressed in adipocytes and involved in regulating fat storage, primarily by modulating hormone sensitive lipase (HSL) activity and thereby mediating triacylglycerol hydrolysis in the fat depots (44).

Targeting overweight and obesity or preventing weight gain during lifetime is a way to decrease metabolic risk factors of several diseases related to the excess of body weight and fat mass. The metabolic profile remarkably improves as a result of the energy restriction with both sustained-protein intake levels resulting in reduction of fat mass and body weight. Systolic and diastolic blood pressure, HOMA-index, and plasma concentrations of glucose, insulin, TAG and LDL and total cholesterol decrease as a result of body-weight loss due to the dietary intervention. Blood pressure, glucose, insulin and HOMA-index remain decreased after weight maintenance. Furthermore, low carbohydrate reinforces this long-term decrease in glucose, insulin and HOMAindex. These improved metabolic parameters are related to the decrease in waist circumference and body weight, thereby showing the beneficial effect of reduction of body weight and regional fat depots. Protein-rich diets also previously showed favorable effects on some metabolic syndrome risk markers. They improved blood pressure (45-47), glycemic control (48-51) and fasting plasma lipid profile concentrations, i.e. they resulted into a greater increase in HDL cholesterol $(43,46,52$, $53)$, a greater reduction of LDL cholesterol $(16,46,52,53)$ and a greater reduction of TAG $(34,46,52,53)$ after body-weight loss $(16,34,43,46,52-54)$ and during weight maintenance $(52,53)$, and decreases in TAG and FFA during energy balance (29). High-protein diets therefore reduce the risk of cardiovascular disease (55).

Perceiving protein intake via mechanisms such as satiety and diet induced energy expenditure influence compliance to the diet and thereby impacts body weight development over time. A decrease in body weight over time is reached by ad libitum high-protein diets vs. normal-protein diets $(4,28,29)$. The question remains what the optimal protein intake, irrespective of energy intake, is during energy balance, energy restriction and weight maintenance thereafter in the broad range of normal weight to severe obese individuals. The WHO-report no. 935 'Protein and amino acid requirements in human nutrition' states that 'the value accepted for the safe level of protein intake' is $0.83 \mathrm{~g} / \mathrm{kg}$ body weight per day. Our protocols repeatedly succeeded in creating a contrast in protein intake between a supra-sustained-protein (SSP) diet and a sustained-protein (SP) diet, i.e. 1.0 to 1.2 vs. 0.7 to $0.8 \mathrm{~g} / \mathrm{kg}$ body weight. We confirmed the presence and magnitude of intervention by quantifying the grams of protein intake using 24-hour urine nitrogen content. We did not use dietary record methods, as they are prone to misreporting (56).

The level of sustained-protein intake influences reduction of body weight and fat mass during energy restriction. A strict energy restriction (-67\% of energy intake) of 3 months in severe obese individuals (BMI $>35 \mathrm{~kg} / \mathrm{m}^{2}$ ) decreased body weight and fat mass significantly more; $-13 \%$ vs. $-10 \%$ body weight and $-26 \%$ vs. $-19 \%$ fat mass of protein intakes 1.1 vs. $0.7 \mathrm{~g} / \mathrm{kg}$ body weight, whereas a strict energy restriction of only 1 month in obese individuals (BMI $>30 \mathrm{~kg} / \mathrm{m}^{2}$ ) decreased body weight and fat mass in both 1.2 and $0.8 \mathrm{~g} / \mathrm{kg}$ body weight by $-6 \%$ body weight and $-13 \%$ fat mass. Reduction of body weight is not affected by protein type. Despite short-term promising higher satiety effects of the protein alpha-lactalbumin, a whey peptide containing relatively high levels of tryptophan and relatively low levels of large neutral amino acids, alpha- 
lactalbumin does not result into better long-term effects compared to a complete protein having all essential amino acids, i.e. milk-protein. Furthermore, efficacy of protein intake of $1.2 \mathrm{~g} / \mathrm{kg}$ body weight on reduction of body weight is reinforced by a decreased carbohydrate intake during energy restriction, however not during weight maintenance. On the other hand, the supra-sustained-protein intake with normalcarbohydrate intake is most effective in limiting body-weight regain after the successful weight loss. Thus, there is an overall effect of supra-sustained-protein intake on weight loss and weight maintenance thereafter.

Sparing of fat free mass during energy-restriction is achieved from a sustained protein intake of $0.8 \mathrm{~g} / \mathrm{kg}$ body weight onwards, as fat free mass decreases less compared to predicted losses of $-33 \%$ loss of fat free mass as a percentage of bodyweight loss during energy restriction (57). Theoretically, a restriction of 26-30 MJ results in reduction of $1 \mathrm{~kg}$ body mass, based upon loss of $0.67 \mathrm{~kg}$ fat mass with an energy content of $37 \mathrm{MJ} / \mathrm{kg}$ plus loss of $0.33 \mathrm{~kg}$ fat free mass with an energy content of 4-6 $\mathrm{MJ} / \mathrm{kg}$ (the water fraction of fat free mass is about $73 \%$, thus about $27 \%$ of $17 \mathrm{MJ} / \mathrm{kg}$ ) (57). The sustained-protein intake restricts losses of fat free mass to $-22 \%$ during strict energy restriction in the obese individuals. The higher supra-sustainedprotein intake is even more successful in sparing of fat free mass and restricts losses of fat free mass to $12 \%$. After an additional 4 months of mild energy restriction $(-33 \%$ of energy restriction) fat free mass equals baseline values despite a reduction of $7 \%$ in body weight after the supra-sustained-protein intake of $1.2 \mathrm{~g} / \mathrm{kg}$ body weight. In the severe obese individuals fat free mass did not decrease more after 3 months of strict energy restriction in the supra-sustained-protein vs. the sustained-protein diet despite the significant larger decrease in body weight, thereby reflecting a better sparing of fat free mass. In a preventive approach of weight gain, energy balanced normal weight subjects (BMI 20-25 kg/m ${ }^{2}$ ) differ significantly in change in fat percentage over time; $1.0 \%$ vs. $0.3 \%$ with protein intakes of $1.2 \mathrm{vs} .0 .9 \mathrm{~g} / \mathrm{kg}$ body weight, without change in body weight and physical activity over 3 months of dietary intervention. The increase in protein intake to $1.2 \mathrm{~g} / \mathrm{kg}$ body weight increased fat free mass and stimulated fat oxidation during an incremental bicycle test independently of change in body weight over the intervention period. The variation in this stimulated fat oxidation is mainly determined by protein intake and fat free mass. Furthermore, the protein intake of 1.2 $\mathrm{g} / \mathrm{kg}$ body weight during the intervention explains $51 \%$ of the variation in fat percentage after the intervention. As a result of the more successful sparing of fat free mass of the supra-sustained-protein diet, resting energy expenditure as a function of fat free mass does not decrease in the obese individuals. Successful sparing of fat free mass hereby facilitates maintenance of reduced body weight, as also was shown before after elevated protein intakes $(5,16,33,34,41-43)$.

Summarizing, the extra-elevated protein intake, i.e. $1.2 \mathrm{vs} .0 .8 \mathrm{~g} / \mathrm{kg}$ body weight either shows its beneficial effects in a larger reduction of body weight and fat mass or larger sparing of fat free mass and preserving resting energy expenditure during the loss of body weight.

There was some concern that the acid load of protein rich sulfur-containing amino acids, methionine and cysteine diets would be partially buffered by bone, and therefore result in a negative calcium balance (58). Increased urinary calcium excretion however, stimulates increased intestinal calcium absorption without contribution from bone 
resorption (59), and thus does not result in negative protein-induced effects on calcium balance $(60,61)$, or bone turnover $(33,59,62,63)$. Hypercalciuria moreover, can be compensated by an elevated calcium intake (64). Therefore, it is advisable that protein supplements are rich in calcium. Furthermore, it is advisable to consume 4 servings of fruit or vegetable per day, because consumption of alkali-rich foods like fruits and vegetables buffer acidic loads (65). Sustaining protein intake levels of 0.8 to $1.2 \mathrm{~g} / \mathrm{kg}$ body weight per day does not change kidney function parameters over time. Creatinin-clearence of the kidney does not decrease and remained between normal values of 60 to $120 \mathrm{micromol} / \mathrm{L}$ urinary creatinin over 24 hours. Furthermore, the link between protein intake and initiation or progression of renal disease lacks evidence in healthy individuals $(24,66)$. Regarding these protein-rich diets, some caution is needed when protein intake is elevated in an absolute sense for a longer phase in individuals with sub-clinical renal functioning, such as the metabolic syndrome or diabetes mellitus type 2, and elderly, which are especially vulnerable for a decrease in kidney function (67). The WHO-report no. 935 'Protein and amino acid requirements in human nutrition' states that 'the value accepted for the safe level of protein intake is $0.83 \mathrm{~g} / \mathrm{kg}$ per day'. Furthermore, it states that 'no safe upper limit has been identified, and it is unlikely that intakes of twice the safe level are associated with any risk'.

\section{CONCLUSIONS}

Macronutrient composition of the diet has a significant impact on body-weight development. Protein need reinforced by increase in dietary restraint, decrease in disinhibition of control, and decrease in subjective feeling of hunger influence compliance to the diet and thereby rate of success of the diet. A contrast in protein intake between a supra-sustained-protein diet and a sustained-protein diet, i.e. 1.2 vs. $0.8 \mathrm{~g} / \mathrm{kg}$ body weight, influences short- and long-term factors of success. The suprasustained-protein intake increases the reduction of body weight and fat mass and increases the sparing of fat free mass and the preserving of resting energy expenditure during the loss of body weight as a result of energy restriction, and increases stimulated fat oxidation and the reduction of fat percentage in weight stable conditions. The efficacy of this level of protein intake is reinforced by a low-carbohydrate intake during energy restriction, resulting in more decrease in glucose, insulin and HOMAindex, however not during weight maintenance. Supra-sustained-protein intake with normal-carbohydrate intake is most effective in limiting body-weight regain after the successful weight loss. The genetic background of perilipin furthermore influences body weight regulation during a weight loss and weight maintenance intervention.

\section{IMPLICATIONS FOR FUTURE RESEARCH}

Compliance to the diet determines to a great extent the outcomes of a weight-loss weight-maintenance dietary intervention. Better understanding of the interaction of subjects' genetic background, compliance to the diet, and the diet itself is therefore a logical continuation of the present research for improvement of targeting obesity. Individuals benefit from energy-restricted diets that improve weight maintenance after successful weight loss and simultaneously improve metabolic risk parameters. This way, it is possible to achieve a scientific background for a sensible and sensitive diet 
that promises not only the desired result but also implies the possibility to be executed by the target group. Further research of efficacy of a successful dietary macronutrient composition on lowering glucose, insulin and plasma lipids could therefore be beneficial for certain risk populations.

Furthermore, knowledge of the genetic background of subjects' extent to suppress hunger and subjects' extent of rewarding value of the food consumed, improves the diversity of a dietary approach to decrease the excess of body weight and fat mass. Subjects with a favorable genetic background regarding suppressing hunger and having a high rewarding value of the food consumed would successfully benefit from an energy-restriction approach, and therefore do not necessarily need to be overweight or obese. Whereas subjects with a less favorable genetic background would benefit from increased counseling. Furthermore, especially these latter subjects need attention for prevention of weight gain during lifetime, regarding their inability to successfully suppress hunger and their trigger of consuming a daily excess of food to achieve a sufficient level of rewarding value of the food consumed. 


\section{REFERENCES}

1. Simpson SJ, Raubenheimer D. Obesity: the protein leverage hypothesis. Obes Rev 2005;6:13342.

2. Astrup A. The satiating power of protein--a key to obesity prevention? Am J Clin Nutr 2005;82:1-2.

3. Lejeune MP, Kovacs EM, Westerterp-Plantenga MS. Additional protein intake limits weight regain after weight loss in humans. Br J Nutr 2005;93:281-9.

4. Weigle DS, Breen PA, Matthys CC, et al. A high-protein diet induces sustained reductions in appetite, ad libitum caloric intake, and body weight despite compensatory changes in diurnal plasma leptin and ghrelin concentrations. Am J Clin Nutr 2005;82:41-8.

5. Westerterp-Plantenga MS, Lejeune MP, Nijs I, van Ooijen M, Kovacs EM. High protein intake sustains weight maintenance after body-weight loss in humans. Int J Obes Relat Metab Disord 2004;28:57-64.

6. Westman EC, Yancy WS, Edman JS, Tomlin KF, Perkins CE. Effect of 6-month adherence to a very low carbohydrate diet program. Am J Med 2002;113:30-6.

7. Westerterp-Plantenga MS, Rolland V, Wilson SA, Westerterp KR. Satiety related to $24 \mathrm{~h}$ diet induced thermogenesis during high protein/carbohydrate vs high fat diets measured in a respiration chamber. Eur J Clin Nutr 1999;53:495-502.

8. Westerterp Plantenga MS, Rolland V, Wilson SA, Westerterp KR. Satiety related to $24 \mathrm{~h}$ diet induced thermogenesis during high protein/carbohydrate vs high fat diets measured in a respiration chamber. Eur J Clin Nutr 1999;53:495-502.

9. Robinson AM, Williamson DH. Physiological roles of ketone bodies as substrates and signals in mammalian tissues. Physiol Rev 1980;60:143-87.

10. Johnstone AM, Horgan GW, Murison SD, Bremner DM, Lobley GE. Effects of a high-protein ketogenic diet on hunger, appetite, and weight loss in obese men feeding ad libitum. Am J Clin Nutr 2008;87:44-55.

11. Boden G, Sargrad K, Homko C, Mozzoli M, Stein TP. Effect of a low-carbohydrate diet on appetite, blood glucose levels, and insulin resistance in obese patients with type 2 diabetes. Ann Intern Med 2005;142:403-11.

12. Scharrer E. Control of food intake by fatty acid oxidation and ketogenesis. Nutrition 1999;15:704-14.

13. Langhans W. Fatty acid oxidation in the energostatic control of eating--a new idea. Appetite 2008;51:446-51.

14. Kahler A, Zimmermann M, Langhans W. Suppression of hepatic fatty acid oxidation and food intake in men. Nutrition 1999;15:819-28.

15. Raben A, Agerholm-Larsen L, Flint A, Holst JJ, Astrup A. Meals with similar energy densities but rich in protein, fat, carbohydrate, or alcohol have different effects on energy expenditure and substrate metabolism but not on appetite and energy intake. Am J Clin Nutr 2003;77:91-100.

16. Parker B, Noakes M, Luscombe N, Clifton P. Effect of a high-protein, high-monounsaturated fat weight loss diet on glycemic control and lipid levels in type 2 diabetes. Diabetes Care 2002;25:425-30.

17. Westerterp KR, Wilson SA, Rolland V. Diet induced thermogenesis measured over $24 \mathrm{~h}$ in a respiration chamber: effect of diet composition. Int J Obes Relat Metab Disord 1999;23:287-92.

18. Tappy L. Thermic effect of food and sympathetic nervous system activity in humans. Reprod Nutr Dev 1996;36:391-7.

19. Nair KS, Halliday D, Garrow JS. Thermic response to isoenergetic protein, carbohydrate or fat meals in lean and obese subjects. Clin Sci (Lond) 1983;65:307-12.

20. Dauncey MJ, Bingham SA. Dependence of $24 \mathrm{~h}$ energy expenditure in man on the composition of the nutrient intake. Br J Nutr 1983;50:1-13.

21. Luscombe-Marsh ND, Noakes M, Wittert GA, Keogh JB, Foster P, Clifton PM. Carbohydraterestricted diets high in either monounsaturated fat or protein are equally effective at promoting fat loss and improving blood lipids. Am J Clin Nutr 2005;81:762-72. 
22. Dulloo AG, Jacquet J. Low-protein overfeeding: a tool to unmask susceptibility to obesity in humans. Int J Obes Relat Metab Disord 1999;23:1118-21.

23. Stock MJ. Gluttony and thermogenesis revisited. Int J Obes Relat Metab Disord 1999;23:110517.

24. Halton TL, Hu FB. The effects of high-protein diets on thermogenesis, satiety and weight loss: a critical review. J Am Coll Nutr 2004;23:373-85.

25. Westerterp-Plantenga MS. The significance of protein in food intake and body weight regulation. Curr Opin Clin Nutr Metab Care 2003;6:635-8.

26. Tessari P, Kiwanuka E, Zanetti M, Barazzoni R. Postprandial body protein synthesis and amino acid catabolism measured with leucine and phenylalanine-tyrosine tracers. Am J Physiol Endocrinol Metab 2003;284:E1037-42.

27. van Milgen J. Modeling biochemical aspects of energy metabolism in mammals. J Nutr 2002;132:3195-202.

28. Due A, Toubro S, Skov AR, Astrup A. Effect of normal-fat diets, either medium or high in protein, on body weight in overweight subjects: a randomised 1-year trial. Int J Obes Relat Metab Disord 2004;28:1283-90.

29. Skov AR, Toubro S, Ronn B, Holm L, Astrup A. Randomized trial on protein vs carbohydrate in ad libitum fat reduced diet for the treatment of obesity. Int $J$ Obes Relat Metab Disord 1999;23:528-36.

30. Halliday D, Hesp R, Stalley SF, Warwick P, Altman DG, Garrow JS. Resting metabolic rate, weight, surface area and body composition in obese women. Int J Obes 1979;3:1-6.

31. Ravussin E, Lillioja S, Anderson TE, Christin L, Bogardus C. Determinants of 24-hour energy expenditure in man. Methods and results using a respiratory chamber. J Clin Invest 1986;78:1568-78.

32. Krieger JW, Sitren HS, Daniels MJ, Langkamp-Henken B. Effects of variation in protein and carbohydrate intake on body mass and composition during energy restriction: a meta-regression 1. Am J Clin Nutr 2006;83:260-74.

33. Farnsworth E, Luscombe ND, Noakes M, Wittert G, Argyiou E, Clifton PM. Effect of a highprotein, energy-restricted diet on body composition, glycemic control, and lipid concentrations in overweight and obese hyperinsulinemic men and women. Am J Clin Nutr 2003;78:31-9.

34. Layman DK, Boileau RA, Erickson DJ, et al. A reduced ratio of dietary carbohydrate to protein improves body composition and blood lipid profiles during weight loss in adult women. J Nutr 2003;133:411-7.

35. Piatti PM, Monti F, Fermo I, et al. Hypocaloric high-protein diet improves glucose oxidation and spares lean body mass: comparison to hypocaloric high-carbohydrate diet. Metabolism 1994;43:1481-7.

36. Hoffer LJ, Bistrian BR, Young VR, Blackburn GL, Matthews DE. Metabolic effects of very low calorie weight reduction diets. J Clin Invest 1984;73:750-8.

37. Lejeune MP, Westerterp KR, Adam TC, Luscombe-Marsh ND, Westerterp-Plantenga MS. Ghrelin and glucagon-like peptide 1 concentrations, 24-h satiety, and energy and substrate metabolism during a high-protein diet and measured in a respiration chamber. Am J Clin Nutr 2006;83:89-94.

38. Harber MP, Schenk S, Barkan AL, Horowitz JF. Effects of dietary carbohydrate restriction with high protein intake on protein metabolism and the somatotropic axis. J Clin Endocrinol Metab 2005;90:5175-81.

39. Garlick PJ, McNurlan MA, Patlak CS. Adaptation of protein metabolism in relation to limits to high dietary protein intake. Eur J Clin Nutr 1999;53 Suppl 1:S34-43.

40. Pannemans DL, Wagenmakers AJ, Westerterp KR, Schaafsma G, Halliday D. Effect of protein source and quantity on protein metabolism in elderly women. Am J Clin Nutr 1998;68:1228-35.

41. Lejeune MP, Kovacs EM, Westerterp Plantenga MS. Additional protein intake limits weight regain after weight loss in humans. Br J Nutr 2005;93:281-9.

42. Deibert P, Konig D, Schmidt-Trucksaess A, et al. Weight loss without losing muscle mass in preobese and obese subjects induced by a high-soy-protein diet. Int J Obes Relat Metab Disord 2004;28:1349-52. 
43. Baba NH, Sawaya S, Torbay N, Habbal Z, Azar S, Hashim SA. High protein vs high carbohydrate hypoenergetic diet for the treatment of obese hyperinsulinemic subjects. Int J Obes Relat Metab Disord 1999;23:1202-6.

44. Greenberg AS, Egan JJ, Wek SA, Moos MC, Jr., Londos C, Kimmel AR. Isolation of cDNAs for perilipins $\mathrm{A}$ and $\mathrm{B}$ : sequence and expression of lipid droplet-associated proteins of adipocytes. Proc Natl Acad Sci U S A 1993;90:12035-9.

45. Appel LJ, Sacks FM, Carey VJ, et al. Effects of protein, monounsaturated fat, and carbohydrate intake on blood pressure and serum lipids: results of the OmniHeart randomized trial. Jama 2005;294:2455-64.

46. Hu FB. Protein, body weight, and cardiovascular health. Am J Clin Nutr 2005;82:242S-247S.

47. Appel LJ, Moore TJ, Obarzanek E, et al. A clinical trial of the effects of dietary patterns on blood pressure. DASH Collaborative Research Group. N Engl J Med 1997;336:1117-24.

48. Promintzer M, Krebs M. Effects of dietary protein on glucose homeostasis. Curr Opin Clin Nutr Metab Care 2006;9:463-8.

49. Manco M, Mingrone G. Effects of weight loss and calorie restriction on carbohydrate metabolism. Curr Opin Clin Nutr Metab Care 2005;8:431-9.

50. Gannon MC, Nuttall FQ. Effect of a high-protein, low-carbohydrate diet on blood glucose control in people with type 2 diabetes. Diabetes 2004;53:2375-82.

51. Gannon MC, Nuttall FQ, Saeed A, Jordan K, Hoover H. An increase in dietary protein improves the blood glucose response in persons with type 2 diabetes. Am J Clin Nutr 2003;78:734-41.

52. Wolfe BM, Piche LA. Replacement of carbohydrate by protein in a conventional-fat diet reduces cholesterol and triglyceride concentrations in healthy normolipidemic subjects. Clin Invest Med 1999;22:140-8.

53. Wolfe BM, Giovannetti PM. Short-term effects of substituting protein for carbohydrate in the diets of moderately hypercholesterolemic human subjects. Metabolism 1991;40:338-43.

54. Noakes M, Clifton PM. Weight loss and plasma lipids. Curr Opin Lipidol 2000;11:65-70.

55. Hu FB, Stampfer MJ, Manson JE, et al. Dietary protein and risk of ischemic heart disease in women. Am J Clin Nutr 1999;70:221-7.

56. Westerterp KR, Goris AH. Validity of the assessment of dietary intake: problems of misreporting. Curr Opin Clin Nutr Metab Care 2002;5:489-93.

57. Westerterp KR, Meijer GA, Kester AD, Wouters L, ten Hoor F. Fat free mass as a function of fat mass and habitual activity level. Int J Sports Med 1992;13:163-6.

58. Hegsted M, Linkswiler HM. Long-term effects of level of protein intake on calcium metabolism in young adult women. J Nutr 1981;111:244-51.

59. Kerstetter JE, O'Brien KO, Caseria DM, Wall DE, Insogna KL. The impact of dietary protein on calcium absorption and kinetic measures of bone turnover in women. J Clin Endocrinol Metab 2005;90:26-31.

60. Skov AR, Toubro S, Bulow J, Krabbe K, Parving HH, Astrup A. Changes in renal function during weight loss induced by high vs low-protein low-fat diets in overweight subjects. Int $\mathrm{J}$ Obes Relat Metab Disord 1999;23:1170-7.

61. Pannemans DL, Schaafsma G, Westerterp KR. Calcium excretion, apparent calcium absorption and calcium balance in young and elderly subjects: influence of protein intake. Br $\mathrm{J} \mathrm{Nutr}$ 1997;77:721-9.

62. Bonjour JP. Dietary protein: an essential nutrient for bone health. J Am Coll Nutr 2005;24:526S$36 \mathrm{~S}$.

63. Heaney RP. Protein intake and the calcium economy. J Am Diet Assoc 1993;93:1259-60.

64. Weikert C, Walter D, Hoffmann K, Kroke A, Bergmann MM, Boeing H. The relation between dietary protein, calcium and bone health in women: results from the EPIC-Potsdam cohort. Ann Nutr Metab 2005;49:312-8.

65. Barzel US, Massey LK. Excess dietary protein can adversely affect bone. J Nutr 1998;128:1051-3.

66. Martin WF, Armstrong LE, Rodriguez NR. Dietary-protein intake and renal function. Nutr Metab (Lond) 2005;2:25.

67. Hoy WE, Hughson MD, Bertram JF, Douglas-Denton R, Amann K. Nephron number, hypertension, renal disease, and renal failure. J Am Soc Nephrol 2005;16:2557-64. 



\section{SUMMARY}


This thesis deals with the following key-question in body weight management, namely whether the decrease in body weight and limited weight regain thereafter and its related metabolic risk factors, can be optimized by adjusted macronutrient composition of the diet. The first question is, whether a sustained and/or supra-sustained daily protein intake would be beneficial in weight stable conditions, and during weight loss and weight maintenance thereafter. Second, to what extent protein type or ratio of carbohydrate and fat would influence the results of an energy-restriction program on weight loss and weight maintenance thereafter. Third, if preloads containing sucrose, High Fructose Corn Syrup (HFCS), or milk differ in short-term satiating effects. Fourth, to what extent the genetic background of perilipin interacts with a differential response to a weight -loss weight-maintenance dietary intervention.

Overweight and obesity develop due to a minor daily positive energy balance over a long period of time. Oppositely, a major negative energy balance over a short period of time, i.e. bouts of energy restriction, traditionally targets the state of excess body weight. The resulting rapid decrease in body weight also decreases daily energy expenditure. This is mainly due to a decrease in fat free mass, the main determinant of energy expenditure. In this respect, an increased protein to carbohydrate and fat ratio in the diet results into an increased ratio of fat free mass to fat mass.

Regarding the period of body-weight loss and more importantly weight maintenance thereafter, the question remains whether the decrease in body weight can be optimized by adjusted macronutrient composition of the diet. We hypothesized, based upon the protein leverage hypothesis, that sustaining a protein intake of $0.8 \mathrm{~g} / \mathrm{kg}$ body weight, a WHO advised daily amount in weight stable conditions, during energy restriction would optimize body-weight loss, i.e. result in a more favorable body composition of increased fat free mass to fat mass ratio, and weight maintenance thereafter. It appeared that sustained absolute protein intake of $0.7-0.8 \mathrm{~g} / \mathrm{kg}$ body weight irrespective of energy intake, thus relatively increased protein intake during energy restriction, supports reduction of fat mass, and limits reduction of fat free mass and energy expenditure compared to predicted-losses based upon the amount of bodyweight loss.

The then following question was whether a supra-sustained daily protein intake would be beneficial during weight loss. The supra-sustained absolute daily protein intake, of $1.0-1.2$ vs. $0.7-0.8 \mathrm{~g} / \mathrm{kg}$ body weight is (i) more successful in decreasing body weight and fat mass co-occurring with a similar decrease in fat free mass, and (ii) more successful in sparing fat free mass and preserving energy expenditure cooccurring with a similar decrease in body weight and fat mass during energy restriction in overweight to severe obese individuals.

With respect to weight maintenance thereafter, the supra-sustained absolute protein intake is more successful in limiting weight regain upon body-weight loss. These effects were confirmed in a weight stable situation when subjects were in energy balance; therefore they also play a role in preventing the accumulation of a positive energy balance during lifetime leading to overweight and obesity. An increase in protein intake to $1.2 \mathrm{~g} / \mathrm{kg}$ body weight increases fat free mass and increases stimulated fat oxidation independently of change in body weight and physical activity in energy balanced normal-weight subjects. Consequently, the daily protein intake of $1.2 \mathrm{vs}$. $0.9 \mathrm{~g} / \mathrm{kg}$ body weight differs significantly in change in body fat percentage over time. 
Regarding the metabolic risk factors related to the excess of fat mass and body weight, targeting overweight and obesity and preventing weight gain during lifetime with sustained absolute protein intake of $0.8-1.2 \mathrm{~g} / \mathrm{kg}$ body weight is a successful way to decrease blood pressure, and plasma insulin, glucose and lipid profiles, irrespective of possible effects on bone mass or kidney function.

With respect to the ratio of carbohydrate and fat, the efficacy of supra-sustained absolute protein intake during energy restriction is reinforced in combination with lowcarbohydrate intake resulting into greater reduction of body weight. Oppositely, combination with normal carbohydrate intake is most effective in limiting body-weight regain upon successful weight loss.

Maintaining the achieved reduction of fat mass and body weight is the difficult part concerning treatment of overweight and obesity. Weight regain upon body-weight loss is limited by an improved body composition during weight loss. The increased ratio of fat free mass to fat mass preserves the drop in daily energy expenditure. Building up of fat free mass by whole body nitrogen retention is induced by a positive protein balance. Presence and magnitude of a protein-intervention needs to be confirmed by quantifying the grams of protein intake using 24-hour urine nitrogen content. Proteins are furthermore energetically inefficient and induce the highest thermogenic response after a meal of all macronutrients. This elevated thermogenesis thereby supports a negative energy balance and is able to facilitate body-weight maintenance despite previous body-weight loss. Weight loss and weight maintenance thereafter is furthermore optimized in a diet with high compliance. Compliance to the diet is supported by increase in dietary restraint, a measure of control of food intake by thought and will power, and decrease in disinhibition of control, and an incidental inability to resist eating cues. Compliance to the diet is furthermore supported by a decreased level of hunger and an increased level of satiety. Of all macronutrients, protein is the most satiating. The satiety effect of sustained absolute protein intake of $1.0-1.2 \mathrm{~g} / \mathrm{kg}$ body weight is reinforced in combination with low-carbohydrate intake resulting into greater reduction of body weight during energy restriction. A mechanism underscoring this very strong satiety effect may be based upon the ketogenic state created by this diet. Furthermore, lowering carbohydrate intake with constant protein intake increases intake of fat, the third macronutrient. The relatively high fat intake in combination with low carbohydrate intake during this diet results in increased postprandial fat oxidation. Increased postprandial fat oxidation in combination with the formation of ketone bodies, such as beta-hydroxybutyrate, reinforces the already high satiety capacity of supra-sustained-protein intake and is thus related to appetite reduction and greater reduction of body weight in energy-restricted humans. Over the long term however, increased hepatic gluconeogenesis consequently creates a situation where protein requirements are increased, and thereby possibly interferes with weight management upon weight loss.

Moreover, promising short-term effects are not always translated into long-term effects. Concerning protein type effecting reduction of body weight, alpha-lactalbumin, a protein containing relatively high levels of tryptophan and relatively low levels of large neutral amino acids, does not affect loss of body weight compared to a complete protein having all essential amino acids, i.e. milk-protein. Furthermore, short-term effects of preloads containing sucrose, HFCS, or milk do not differ in satiety, 
compensation, or overconsumption despite differences in biochemical properties and differences in mechanisms underlying satiety in relation to GLP-1 and ghrelin release. A dietary approach to target overweight and obesity can furthermore be optimized by personalization of the treatment. Knowledge of the genetic background of the metabolism involved in energy intake and/or energy expenditure and genetic susceptibility to an energy restriction intervention can help to reach and maintain a negative energy balance during weight loss and weight maintenance thereafter, or prevent a positive energy balance during lifetime. For example the genetic background of perilipin interacts with a differential response to a weight-loss weight-maintenance dietary intervention, supported by a differential effect on body composition, especially body fat, as perilipin is expressed in adipocytes and involved in regulating fat storage. Therefore, further knowledge of both genetic and environmental factors, such as the diet, can impact treatment and prevention of overweight and obesity.

In conclusion, sustained absolute daily protein intake irrespective of energy intake is effective for optimizing body-weight loss and the important weight maintenance thereafter, while supra-sustained absolute daily protein intake is even more effective. Mechanisms underscoring these effects are limited reduction of fat free mass, limited drop in energy expenditure, increased reduction of fat mass, increased stimulated fat oxidation, decreased hunger, and good compliance to the diet, without negatively affecting bone mass and kidney function. The optimized diet therefore influences short- and long-term factors of successful treatment and prevention of overweight and obesity during lifetime. 

Dit proefschrift getiteld: 'Doeltreffendheid van macronutriënten gericht op het verlagen van overgewicht en meer', behandelt het optimaliseren van verlaging in lichaamsgewicht en het daaropvolgende behoud van gewicht met behulp van optimalisering van de macronutriënt verhouding van de dagelijkse voedselinname. Ten eerste wordt de vraag gesteld of het handhaven van de aanbevolen absolute dagelijkse eiwit inname of juist een verhoging hiervan resulteert in verbeterde handhaving van een stabiel lichaamsgewicht in energiebalans, een verbeterde verlaging van het lichaamsgewicht tijdens een energiebeperkt dieet en daaropvolgend een beter behoud van het verkregen lichaamsgewicht. Ten tweede, in hoeverre de ratio van de overige twee macronutriënten koolhydraat en vet van belang is bij verlaging van het lichaamsgewicht en het daaropvolgende behoud van het gewicht op genoemde eiwitdiëten. Ten derde, of sucrose, High Fructose Corn Syrup (HFCS) en melk verschillen in korte termijn effecten op verzadiging. Ten vierde, in welke mate de genetische blauwdruk van het eiwit perilipine de effecten van verlaging van het lichaamsgewicht en daaropvolgend behoud van het gewicht beïnvloedt.

Overgewicht is een erkend maatschappelijk probleem dat gepaard gaat met een verhoogd gezondheidsrisico en verlaagde levenskwaliteit. Verlaging in energie inname resulteert in verlaging van overgewicht. Echter, het handhaven van het verlaagde lichaamsgewicht is moeilijk vol te houden. Hierbij is met name de lichaamssamenstelling van belang. De wijze waarop het lichaamsgewicht verlaagd wordt is een cruciale factor. Met name de overvloed aan vetmassa, die gepaard gaat met overgewicht is gerelateerd aan het verhoogde gezondheidsrisico. Voorts bepaalt de vetvrije massa, bestaande uit organen, spiermassa en botmassa, het dagelijkse energiegebruik. Dit energiegebruik daalt tijdens verlaging van het lichaamsgewicht. Het is dus van belang om het energiegebruik zo goed mogelijk te handhaven om zo de frequent geconstateerde gewichtstoename na eerdere gewichtsafname te beperken. Daarom is het relevant om de vetmassa wel maar de vetvrije massa niet te reduceren tijdens het verlagen van het lichaamsgewicht.

Betreffende verlaging van het lichaamsgewicht met behulp van verlaging in energie inname en het daaropvolgende behoud van het verlaagde gewicht is de vraag wat de meest optimale macronutriënt samenstelling van de dagelijkse voedselinname is. Uit deze vraag volgt de hypothese dat het handhaven van absolute dagelijkse eiwit inname van de WHO aanbeveling van $0.8 \mathrm{~g} / \mathrm{kg}$ lichaamsgewicht tijdens een verlaagde energie inname, dus in dat geval een relatief verhoogde eiwit inname verlaging van lichaamsgewicht en behoud van het verkregen verlaagde gewicht optimaliseert. Voorts is de vraag of een verhoging van deze absolute dagelijkse eiwit inname tot $1.2 \mathrm{~g} / \mathrm{kg}$ lichaamsgewicht tijdens verlaagde energie inname leidt tot verbetering van de resultaten van het dieet. $\mathrm{Na}$ aanpassing van de hoeveelheid eiwit in het dieet resteert de vraag in hoeverre de verhouding van koolhydraat en vet van betekenis zijn.

Dit proefschrift geeft de volgende bevindingen weer: het handhaven van de absolute dagelijkse eiwit inname tijdens verlaagde energie inname, dus een relatieve verhoging van eiwit inname, blijkt reductie in vetmassa te ondersteunen en reductie in vetvrije massa en energiegebruik te remmen ten opzichte van de voorspelde reductie gebaseerd op de verlaging in lichaamsgewicht. Voorts blijkt het handhaven van een absolute dagelijkse eiwit inname van 1.0 tot $1.2 \mathrm{~g} / \mathrm{kg}$ lichaamsgewicht ten opzichte van 0.7 tot $0.8 \mathrm{~g} / \mathrm{kg}$ lichaamsgewicht, tijdens verlaagde energie inname (i) een grotere 
reductie in lichaamsgewicht en een grotere reductie in vetmassa met vergelijkbaar behoud van vetvrije massa en (ii) een geremde daling in vetvrije massa met vergelijkbare verlaging in lichaamsgewicht en vetmassa te bewerkstelligen. Tevens blijkt het handhaven van $1.2 \mathrm{~g} / \mathrm{kg}$ lichaamsgewicht absolute dagelijkse eiwit inname meer succesvol te zijn in het beperken van gewichtstoename na een periode van reductie in lichaamsgewicht. Bovenstaande effecten zijn bevestigd in een periode zonder fluctuatie van het lichaamsgewicht. Hierop gebaseerd zou deze verbetering in lichaamssamenstelling met behulp van een absolute dagelijkse eiwitinname van $1.2 \mathrm{~g} / \mathrm{kg}$ lichaamsgewicht kunnen bijdragen aan een preventieve aanpak van de opstapeling van vetmassa. Een dusdanige eiwitinname blijkt zowel een verhoging in vetvrije massa, als een verhoging in gestimuleerde vetoxidatie te creëren en dit onafhankelijk van verandering in lichaamsgewicht en fysieke activiteit. Deze effecten blijken tot een significant verschil in vetpercentage te leiden tussen absolute dagelijkse eiwit innames van 1.2 en $0.9 \mathrm{~g} / \mathrm{kg}$ lichaamsgewicht per dag. Een dergelijke aanpak ter preventie van toename in lichaamsgewicht en het verlagen van overgewicht blijkt een succesvolle strategie te kunnen zijn om cardiovasculaire risicofactoren met betrekking tot bloeddruk, bloedglucose en vetprofiel te verlagen. Deze positieve resultaten blijken te worden bereikt zonder het teweegbrengen van mogelijke negatieve effecten op de nierfunctie of de botmassa.

Voorts geeft dit proefschrift weer dat de effectiviteit van een dusdanige eiwitinname, tijdens verlaagde energie inname ter verlaging van het lichaamsgewicht, wordt versterkt door een combinatie met een verlaagde koolhydraat inname ten opzichte van vet inname. Een combinatie met een normale koolhydraat inname tijdens gewichtsbehoud bewerkstelligt echter een hogere effectiviteit in het beperken van toename in lichaamsgewicht na een eerdere reductie in gewicht. Gewichtsbehoud is het struikelblok in de aanpak van overgewicht. Toename in lichaamsgewicht na eerdere verlaging kan effectief worden beperkt door middel van een verbeterde lichaamssamenstelling. Een vergroot aandeel van vetvrije massa ten opzichte van vetmassa heeft een gereduceerde daling in energiegebruik als gevolg. Vetvrije massa wordt vergroot door middel van stikstof retentie als gevolg van een positieve eiwitbalans. Hierbij is de stikstof concentratie in de urine een betrouwbare marker ter bepaling van de eiwitinname tijdens de interventie. Naast de opbouw van vetvrije massa draagt de inname van eiwitten via hun energetische inefficiëntie bij aan een verhoogd dagelijks energiegebruik. Dit hoge thermogene effect draagt tevens bij aan het in stand houden van een negatieve energiebalans wat resulteert in een gereduceerd lichaamsgewicht. Verlaging in gewicht en het daaropvolgende behoud ervan blijkt te worden bevorderd met behulp van een trouwe opvolging van het gebruikte dieet. Dieettrouw wordt ondersteund door een verhoging in wilskracht om de voedselinname te beheersen en door het weerstaan van verleiding tot meer voedsel inname. Voorts blijkt dieettrouw te worden ondersteund door een verlaagd hongergevoel en een verhoging in het gevoel van verzadiging. Het macronutriënt welke het sterkste deze eetlust onderdrukking teweeg brengt is eiwit. Dit effect wordt versterkt in combinatie met een gereduceerde inname van koolhydraat ten opzichte van vet, resulterend in een sterkere daling van het lichaamsgewicht tijdens een energiebeperkt dieet. Dit sterke verzadigende effect is mogelijk gebaseerd op de aldus gecreëerde ketogene situatie. Verhoogde postprandiale vetoxidatie in combinatie met de vorming van keton 
lichamen zoals beta-hydroxybutyraat verhoogt het verzadigende effect van een absolute dagelijkse eiwit inname van $1.2 \mathrm{~g} / \mathrm{kg}$ lichaamsgewicht en is gerelateerd aan een sterkere verlaging van het lichaamsgewicht tijdens een energiebeperkt dieet. Bovendien veroorzaakt de verhoogde gluconeogenese van de lever tijdens een ketogene situatie op lange termijn een verhoging in de behoefte aan eiwit inname, en beïnvloedt daardoor mogelijkerwijs de effecten op lichaamsgewicht tijdens de periode na verlaging in lichaamsgewicht. Effecten op korte termijn blijken dus niet altijd vertaald te kunnen worden in effecten op lange termijn. Een eiwit met een relatief hoge concentratie van tryptofaan en relatief lage concentratie van grote ongeladen aminozuren, zoals alfa-lactalbumin, heeft goede verzadigende eigenschappen. Echter geeft dit proefschrift weer dat reductie in lichaamsgewicht na langdurige inname niet verschillend blijkt te zijn van een compleet eiwit dat alle aminozuren bevat, zoals melk eiwit. Voorts blijken drankjen gezoet met sucrose, HFCS of melk niet te verschillen in verzadiging, compensatie of overconsumptie van de daaropvolgende maaltijd die ten grondslag liggen ondanks verschillen in biochemische eigenschappen en verschil in mechanismen aan verzadiging in relatie tot GLP-1 en ghreline.

Behandeling van overgewicht met behulp van een dieet kan geoptimaliseerd worden door middel van een persoonsspecifieke behandeling. Kennis van de genetische achtergrond van het metabolisme betrokken bij energie inname en energie gebruik, en kennis van genetische gevoeligheid ten aanzien van energie inname beperking en het sparen van vetvrije massa kan bijdragen aan het creëren en instandhouden van een negatieve energiebalans ter verlaging van het lichaamsgewicht en daaropvolgend behoud van het gewicht, of kan bijdragen aan preventie van gedurig langzame opbouw van een positieve energiebalans. Dit proefschrift geeft weer dat de genetische blauwdruk van het eiwit perilipine het effect van een interventie met als doel verlaging en daaropvolgend behoud van lichaamsgewicht blijkt te beïnvloeden. Dit blijkt uit een effect op de lichaamssamenstelling met name op afname van lichaamsvet. Waarschijnlijk doordat perilipine betrokken is bij de regulering van de vetopslag en met name aanwezig is in de adipocyten. Meer kennis betreffende de interactie tussen genetica en omgevingsfactoren zoals voedsel inname kan een positieve wending geven aan de aanpak van overgewicht.

Samenvattend, het handhaven van een absolute dagelijkse eiwit inname, onafhankelijk van energie inname, optimaliseert verlaging in lichaamsgewicht en het daaropvolgende behoud van gewicht door middel van beperkte verlaging in vetvrije massa, beperkte verlaging in energiegebruik, gestimuleerde verlaging in vetmassa, gestimuleerde vetoxidatie, gereduceerd gevoel van eetlust en honger, en dieettrouw, zonder een negatief effect op botmassa en nierfunctie te veroorzaken. Hierdoor beïnvloedt een dergelijk geoptimaliseerd dieet korte en lange termijn factoren voor een succesvolle behandeling en preventie van overgewicht en obesitas. 



\section{DANKWOORD}


Graag wil ik onderstaande personen om hun inspiratie bedanken;

Tanja Adam, Moeke Aelbrecht, Hanja Allemekinders, Ludovic van Amelsfoort, Amber Arain, Ilja Arts, Frank van Berkum, An Bielen, Ellen Blaak, Alberto Bonomi, Hanneke Boon, Juriaan Born, Freek Bouwman, Louise Brown, Marc Bruin Slot, Samuel Brunner, Jochen Cals, Eefje Corpeleijn, Rudy De Cock, Kristel Diepvens, Enrico Dierkes, Jaap Dierkes, Jeroen Dierkes, Stijn Donvil, Max Dummer, Maarten Gering, Tim Goessens, Hanne Gonnissen, Juriaan Groutars, Sandra Hamada, Henrike Hamer, Shelly van der Heijden, Berit Heitman, Marcel den Hoed, Edith van den Hooven, Martine Hulsbosch, Rick Hursel, Annemieke Izeboud, Jeroen Janssens, Jos Janssens, Liliane Janssens, Marthe Janssens, Ada Jonker, Annemiek Joosen, Maud Kertzman, Andrea Kodde, Daniel Kotz, Bastiaan Krone, Milie-Eve Larose, Anne de Leij, Manuela Lejeune, Shira van de Laar, Daniel Langer, Sofie Lemmens, Natalie Luscombe Sanne van der Made, Liesbeth Maes, Ralph Manders, Edwin Mariman, Eveline Martens, Mieke Martens, Francisca Matthijs, Ronald Mensink, Desiree Morales, Arie Niewenhuizen, Ans Op de Woerd, Claudia Pachen, Salome Peters, Guy Plasqui, Marijke Prins, Femke Rutters, Paul Schoffelen, Jolande Scholte, Joan Senden, Wendy Sluijsmans, Astrid Smeets, Bart Soenen, Edith Soenen, Luc Soenen, Mirthe Soenen, Mark Spigt, Stan Spigt, Mathilde Steenks, Jos Stegen, Gerard Swaen, Mieke Tempels, Myriam Thijssen, Willem-Jan Toebes, Daniel Tome, Freddy Troost, Øydis Ueland, Petra Uittenbogaard, Els Vandebroek, Christophe Van de Maele, Eveline Vanhaesebroek, Steven Vanhoutvin, Claudia Vaz, Margriet Veldhorst, Ellen van Velzen, Sanne Verhoef, Wolfgang Viechtbauer, Neeltje Vogels, Anneke van Vught, Ananda Waelen, Briek weerkamp, Nico Weerkamp, Ilona Welbergen, Klaas Westerterp, Margriet Westerterp-Plantenga, Loek Wouters, ...,

promotor en co-auteurs voor een fijne en verdiepende samenwerking, collega's voor een boeiende werksfeer, stagiaires voor het verzette werk en de wederzijdse educatie, deelnemers van de studies voor hun inzet, leden van de Journal Club Mesch voor de intense discussies, nieuwe vrienden voor de gezelligheid in Nederland.

Veel dank voor de goede samenwerking aan;

Frank van Berkum en het Previtas-team,

Janine Verheesen en de Suikerstichting Nederland,

Alle partners van Top Institute Food and Nutrition (TIFN).

Special thanks for a great collaboration to;

Louise Brown and Unilever Corporate Research,

Berit Heitmann and the Institute of Preventive Medicine.

Kind thanks for the interest in my work to;

the members of the reading committee of this $\mathrm{PhD}$ thesis and the corona.

Een speciale dank aan;

Margriet Westerterp-Plantenga voor een leerrijke opleiding.

Een uitzonderlijke dank aan;

Gerard, Daniel, Mark en Daniel voor de combinatie wetenschap en ontspanning.

Een bijzondere dank aan;

Judith, mama en papa, Moeke, Ans en Jaap, Bart en Lies, Mirthe en Edith, Enrico en Jeroen voor een warm thuis. 
Merci aan de lezer

Een wel overwogen bonte woordkeuze omvat de intentie van de schrijver. 



\section{LIST OF PUBLICATIONS}




\section{Full papers}

Soenen S, Mariman ECM, Vogels N, Bouwman FG, den Hoed M, Brown L, Westerterp-Plantenga MS. Relationship between perilipin gene polymorphisms and body weight and body composition during weight loss and weight maintenance. Physiol Behav 2009;96:723-728.

Westerterp-Plantenga MS, Niewenhuizen A, Tome D, Soenen S, Westerterp KR. Dietary protein, weight loss and weight maintenance. Ann Rev Nutr 2009;29:11.111.21 .

Soenen S, Westerterp-Plantenga MS. Proteins and satiety: implications for weight management. Curr Opin Clin Nutr Metab Care 2008;11(6):747-751.

Smeets AJPG, Soenen S, Luscombe-Marsh ND, Ueland Ø, Westerterp-Plantenga MS. Energy expenditure, plasma ghrelin, glucagonlikepeptide I, PYY concentratieons and satiety following a single high protein lunch. J Nutr 2008;138(4):698-702.

Corpeleijn E, Pelsers MM, Soenen S, Mensink M, Bouwman FG, Kooi ME, Saris WH, Glatz JF, Blaak EE. Insulin acutely upregulates protein expression of the fatty acid transporter CD36 in human skeletal muscle in vivo. J Physiol Pharmacol 2008;59(1):77-83.

Veldhorst M, Smeets A, Soenen S, Hochstenbach-Waelen A, Hursel R, Diepvens K, Lejeune M, Luscombe-Marsh N, Westerterp-Plantenga M. Quantity and quality of protein in meals and diets related to protein-induced satiety. Physiol Behav 2008;94(2):300-7.

Soenen S, Westerterp-Plantenga MS. No difference in satiety or energy intake after high-fructose corn syrup, sucrose, or milk preloads. Am J Clin Nutr 2007;86:1586-94.

Diepvens K, Soenen S, Steijns J, Arnold M, Westerterp-Plantenga MS. Long-term effects of consumption of a novel fat emulsion in relation to body-weight management. Int J Obesity 2007;31(6):942-949.

Soenen S, Bonomi AG, Scholte J, Thijssen MAMA, van Berkum F, WesterterpPlantenga MS. Elevated protein recommended and lowered carbohydrate additionally suggested for optimal weight loss. Submitted for publication

Soenen S, Scholte J, Thijssen MAMA, van Berkum F, Westerterp-Plantenga MS. Efficacy of elevated protein and lowered carbohydrate on weight maintenance. Submitted for publication

Soenen S, Hochstenbach-Waelen A, Westerterp-Plantenga MS. Sustained intake of required protein optimal for weight loss, supra-sustained protein intake optimal for weight maintenance. Submitted for publication 
Soenen S, Hochstenbach-Waelen A, Westerterp-Plantenga MS. Efficacy of alphalactalbumin for weight loss compared to sustained and supra-sustained milk protein. Submitted for publication

Soenen S, Westerterp-Plantenga MS. Protein intake induced changes in body composition in energy balance. Submitted for publication

Soenen S, Plasqui G, Smeets AJPG, Westerterp-Plantenga MS. Protein intake induced increase in exercise stimulated fat oxidation in energy balance. Submitted for publication

Hochstenbach-Waelen A, Soenen S, Westerterp KR, Westerterp-Plantenga MS. The effects of a suprasustained gelatin-milk protein diet compared with a sustained and a suprasustained milk protein diet during a weight loss-period. Submitted for publication

Hochstenbach-Waelen A, Soenen S, Westerterp KR, Westerterp-Plantenga MS. The effects of a suprasustained gelatin-milk protein diet compared with a sustained and a suprasustained milk protein diet during a weight maintenance-period. Submitted for publication

\section{Abstracts and presentations}

Soenen S, Bonomi AG, Scholte J, Thijssen MAMA, van Berkum F, WesterterpPlantenga MS. Low carbohydrate intake only shows a larger decrease in body weight and fat percentage in the presence of high protein intake. Annual Nutrition and Toxicology Research Institute Maastricht (NUTRIM) Symposium November 2009, Maastricht, The Netherlands. (Poster presentation)

Soenen S, Westerterp-Plantenga MS. Protein leverage in long term weight loss and weight maintenance. International Protein Summit October 2009, Maastricht, The Netherlands. (Invited speaker)

Soenen S, Bonomi AG, Scholte J, Thijssen MAMA, van Berkum F, WesterterpPlantenga MS. Is it relatively high protein or low carbohydrate that promotes bodyweight loss and weight maintenance thereafter? Nederlandse organisatie voor wetenschappelijk onderzoek (NWO) voeding October 2009, Deurne, The Netherlands. (Oral presentation)

Soenen S, Bonomi AG, Scholte J, Thijssen MAMA, van Berkum F, WesterterpPlantenga MS. Low carbohydrate intake only shows a larger decrease in body weight and fat percentage in the presence of high protein intake. Society for the Study of Ingestive Behavior (SSIB) 17th Annual Meeting July 2009, Portland, Oregon, USA. (Poster presentation) Appetite 2009;52(3):859.

Soenen S, Bonomi AG, Scholte J, Thijssen MAMA, van Berkum F, WesterterpPlantenga MS. Elevated protein recommended and lowered carbohydrate additional 
suggested for optimal weight loss. Benjamin Franklin Lafayette (BFL) June 2009, Frejus, France. (Invited speaker)

Soenen S, Bonomi AG, Scholte J, Thijssen MAMA, van Berkum F, WesterterpPlantenga MS. Low carbohydrate intake only shows a larger decrease in body weight and fat percentage in the presence of high protein intake. 17th European Congress on Obesity (ECO) May 2009, Amsterdam, The Netherlands. (Poster presentation) Obesity Facts 2009 May;2 Suppl 2:s140.

Soenen S, Bonomi AG, Scholte J, Thijssen MAMA, van Berkum F, WesterterpPlantenga MS. Low carbohydrate intake only shows a larger decrease in body weight and fat percentage in the presence of high protein intake. 1st Swiss Winter Ingestion Conference February 2009, St Moritz, Swiss. (Invited speaker)

Soenen S, Westerterp-Plantenga MS. Neuropeptides and satiety. Winter Neuropeptides Conference January 2009, Colorado, USA. (Invited speaker)

Soenen S, Plasqui G, Smeets AJPG, Westerterp-Plantenga MS. Protein induced increase in stimulated fat oxidation in energy balance. Nederlandse organisatie voor wetenschappelijk onderzoek (NWO) voeding October 2008, Deurne, The Netherlands. (Oral Presentation)

Soenen S, Plasqui G, Smeets AJPG, Westerterp-Plantenga MS. Protein induced increase in stimulated fat oxidation in energy balance. 30th European Society for Clinical Nutrition and Metabolism (ESPEN) 30th Congress September 2008, Florence, Italy. (Oral presentation) Clinical Nutrition Supplements 2008:3Suppl 1:28.

Soenen S, Westerterp-Plantenga MS. Protein induced increase in fat free mass in energy balance. Society for the Study of Ingestive Behavior (SSIB) 16th Annual Meeting July 2008, Paris, France. (Oral presentation) Appetite 2008;51(2):402.

Soenen S, Westerterp-Plantenga MS. Protein induced increase in fat free mass in energy balance. Annual Nutrition and Toxicology Research Institute Maastricht (NUTRIM) Symposium November 2008, Maastricht, The Netherlands.

Soenen S, Mariman ECM, Vogels N, Bouwman FG, den Hoed M, Brown L, Westerterp-Plantenga MS. Relationship between perilipin gene polymorphisms and weight maintenance after weight loss. Dutch Endo-Neuro-Psycho (ENP) June 2008, Doorwerth, The Netherlands. (Invited speaker)

Soenen S, Westerterp-Plantenga MS. Protein induced sparing of fat free mass in energy balance. Int J Obesity. 16th European Congress on Obesity (ECO) 2008 May, Geneva, Switzerland. (Poster presentation) Int J Obesity May 2008;32 Suppl 1:s70. 
Soenen S, Westerterp-Plantenga MS. Protein induced increase in fat free mass in energy balance. Campina Science Day April 2008, Wageningen, The Netherlands. (Invited speaker)

Soenen S, Westerterp-Plantenga MS. Protein induced increase in fat free mass in energy balance. Nederlandse Associatie voor de Studie van Obesitas (NASO) April 2008, Leiden, The Netherlands. (Oral presentation)

Soenen S, Westerterp-Plantenga MS. Partly energy intake compensation of any type of liquid preload. January 2008, Institute of Preventative Medicine, Copenhagen, Denmark. (Invited speaker)

Soenen S, Mariman ECM, Vogels N, Bouwman FG, den Hoed M, Brown L, Westerterp-Plantenga MS. Relationship between perilipin gene polymorphisms and weight maintenance after weight loss. Nederlandse organisatie voor wetenschappelijk onderzoek (NWO) voeding October 2007, Deurne, The Netherlands. (Oral presentation)

Soenen S, Westerterp-Plantenga MS. Partly energy intake compensation of any type of liquid preload. 10th International Congress on Obesity (ICO) September 2006, Sydney, Australia. (Poster presentation) Obes Rev 2006 Sep; 7 Suppl 2:1-352.

Soenen S, Westerterp-Plantenga MS. Partly energy intake compensation of any type of liquid preload. Society for the Study of Ingestive Behavior (SSIB) 14th Annual Meeting July 2006, Naples, Florida, USA. (Oral presentation) Appetite 2006;46(3):385.

Soenen S, Westerterp-Plantenga MS. Partly energy intake compensation of any type of liquid preload. Benjamin Franklin Lafayette (BFL) June 2006, Frejus, France. (Invited speaker) 

ABOUT THE AUTHOR 

Stijn Soenen was born in Gent, Belgium on the $27^{\text {th }}$ of Februar 1978. He spend his first 16 years of life in Werl, Soest and Neheim, Germany and followed his primary school education at the the 'Boudewijn-I-School' and the first part of his secondary school education at the 'Koninklijk Atheneum' in Soest, Germany. He completed secondary school at the 'Heilig Drievuldigheidscollege' Leuven, Belgium. He graduated with distinction his Diet and Nutrition studies at the 'Katholieke Hoge School' Leuven, Belgium in 2002 with the thesis 'Determination of trans-fatty acids in potato chips with gas-chromatography', which he wrote in collaboration with Prof. dr. Triantafyllou during an internship in

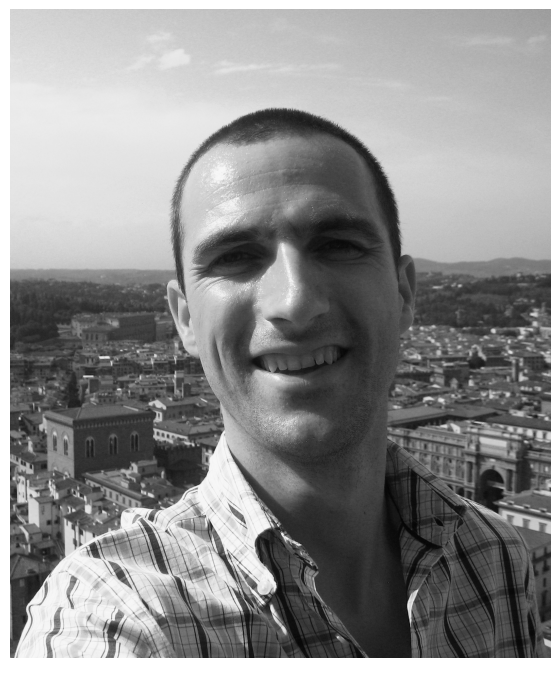
Thessaloniki, Greece. At the department of Human Biology of the Faculty of Health Medicine and Life Sciences (FHML), Maastricht University, he completed his Master of Science degree in Biological Health Science with distinction (cum laude) in 2005 with the thesis: 'Intramyocellular lipid accumulation an early symptom of the insulin resistant condition' in collaboration with Prof. dr. E Blaak. This Master thesis was awarded with the Catharina Pijls Award. He started working during the last year of his studies at the same department as a research assistant for one year on the topic of longterm effects of consumption of a novel fat emulsion in relation to body-weight management under supervision of Prof. dr. M Westerterp-Plantenga. With great interest in the physiology of eating behavior in relation to energy balance, he started his $\mathrm{PhD}$ research as part of a project of Top Institute Food and Nutrition (TIFN) at the department of Human Biology, Maastricht University, in 2005. The research performed during this project is described in this $\mathrm{PhD}$ thesis entitled 'Efficacy of macronutrients on targeting obesity and beyond' and was approved in October 2009. He also was active as a $\mathrm{PhD}$ representative as a member of the Promovendi Commission of the School for Nutrition, Toxicology and Metabolism (NUTRIM), as well as a member of the Interfacultary Promovendi Commission (IPC) of FHML and the Faculty of Psychology (FdP). During his $\mathrm{PhD}$ project he presented several abstracts on international conferences. He received a travelaward from the Netherlands Association of the Study for Obesity (NASO) in 2008. In 2009, he received the Young Investigator Award at the Winter Neuropeptides Conference (WNPC) in Breckenridge, Colorado, USA. In 2008, he went to collaborate with Prof. dr. B Heitmann in Copenhagen, Denmark. He acquired a Kootstra Talent Fellowship from Maastricht University Medical Centre+ (MUMC+) in November 2009 and started as a post-doc at the department of Human Biology to continue his work in the field of body-weight regulation. Besides his work, he likes to combine sports and leisure time with his friends. Furthermore, life and science in general can interestingly be discussed during a journal club (Journal Club Mesch). Above all, he prefers to spend the majority of his private life with his lovely wife Judith Dierkes, MD. 